GERARD DOMBROSK I

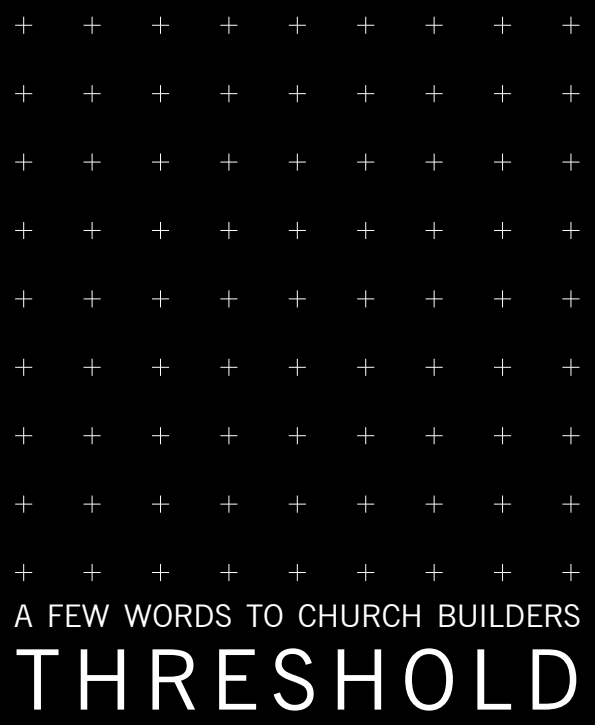


Psalm 127:1 (NIV)

Unless the Lord builds the house,

the builders labor in vain. 
A Thesis submitted in partial

fulfilment of the requirements for

$$
\text { the degree of }
$$

\section{Master of Architecture}

(Professional)

Victoria University of Wellington New Zealand 2014 

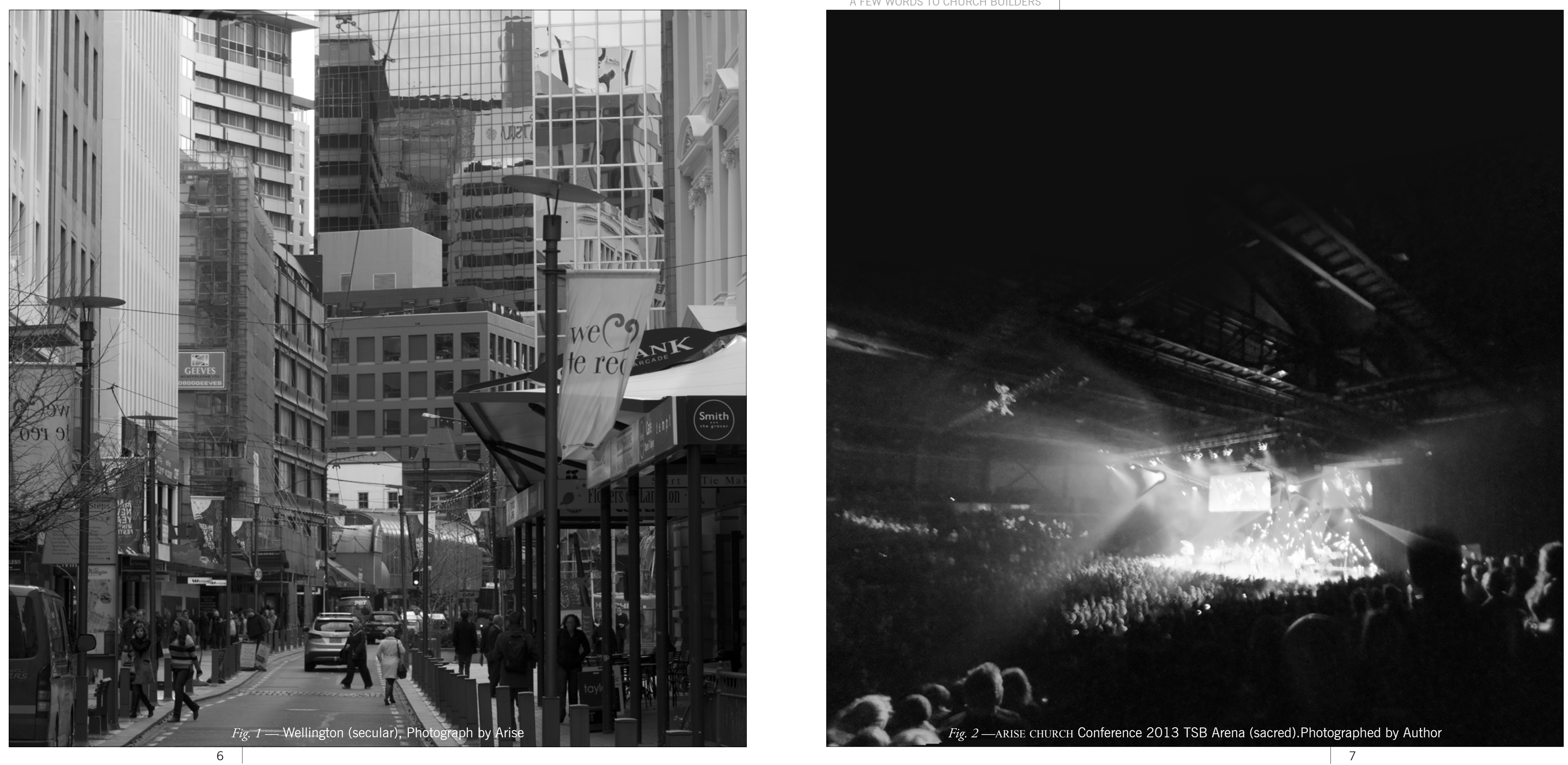


\title{
ABSTRACT
}

Throughout history CHURCHES have been concerned with the sharing of the gospel to those who do not know of the salvation received through Jesus Christ. Through history many churches have innovated liturgical operation using relevant language to

reach as many souls as possible.

In this thesis the proposed design of a Pentecostal Church departs from a Pentecostal Cheparts from traditional Cherm the CHURCH's theological standpoint and focus: to be secular attentive. Traditional Christian Churches are designed to fully enclose the gathering of worshipers. This idea is challenged through this thesis by the theological

standpoint of the Arise church, the

principal client of the design work of

work of

this thesis. Form, envelope, materiality and programme will resolve an
This discussion is between the secular and sacred, focused through the design of permeable threshold, seeking to enable a dialogue from the CHURCH to the secular and the secular to the CHURCH.

\begin{abstract}
.
\end{abstract}


I wish to acknowledge the key support I have received throughout years one to five.

To my Lord and Saviour Jesus Christ through whom all things are possible.

This thesis would have no meaning if not for your sake. I wish this thesis not to sit on a shelf and gather dust

but offer something tangible to the CHURCH.

My supervisor, Philippe Campays, a very clever man who often pointed me towards clarity within times of obscurity. Your guidance and encouragement has been invaluable.

To Arise CHURCH through whom my love for God and his CHURCH has flourished.

To my classmates and friends, who have shared the last five years with me.
To Tim and the crew at Customs Coffee shop where many an hour was spent.

Finally to my parents, Judith and Mark, without their support this thesis would not be possible to complete.

Being a CHURCH goer and a student of architecture, I often question the nature of religious architecture, not only its reflection but facilitation of the CHURCHES, inherent purpose to share the Gospel.

This thesis is not a critique of the traditionaly Church, however their representation of the transcendental through verticality places a gondental th derin of departure into an architectural inquiry; moreover when oppressing vertically of form illustrates a pedestal of power or self reverence. The question arises on whether elaborate and complex architecture glorifies God more than subtle and simple architectural gestures do.

It is important to note that throughout the thesis text, two types of churches the referes the chunch are

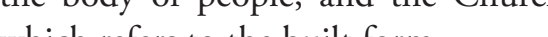
efers to the built form. 


\section{GLOSSARY OF}

TERMS

Church The building- for public Christian worship.

The body of people - affiliated with the wider Christian

The body of people - the Arise church congregation.

Christian

Jesus The Messiah, the Son of the living God.

A person who believes in Jesus Christ.

To meet Jesus through the Holy Spirit.

Secular

regarded as religious, spiritual, or sacred.

Sacred

Pertaining to or connected with religion, opposed to secular.

Evangelical The want to share the Gospe!

Pentecostal A movement within Christianity that places special emphasis

on a direct persona experience of God through the baption

Resurrection The rising of Christ after His death and burial.

Believe To have confidence in the truth, the existence, or the reliability
of something.

Plebeian
Religionless

Belonging or pertaining to the common people.

Religionless Christianity- refers to a new "form" of Christianity

in which people of a genuine Christian faith would live in a more

open, constructive relationship with the world. Freed from an

emphasis on inward piety and empty rituals.

Liturgy A collection of formularies for public worship.

1. Kelly and Nelson. 1995. pg 547 
CONTENTS

ABSTRACT

ACKNOWLEDGEMENTS

FOREWORD

GLOSSARY OF TERMS

INTRODUCTION

THEOLOGICAL CONTEXT

ARISE CHURCH

政

METHODOLOGY

PROCESS

PERCEPTION

INSTINCTIVE DESIGN MOVES

ENVELOPE

ARISE RENTED TYPOLOCY

ENVELOPE IN ARCHITECTURE

SITE MACRO

ARISE SPIRE

ASSAULT

SITE

NON-CHURCH 
CONTENTS

THRESHOLD PRECEDENT

DESIGN ITERATION ONE

SITE SPECIFICITY

DESIGN ITERATION TWO

PRECEDENTS

DESIGN ITERATION THREE

HILLSONG PRECEDENT

LIGHT AND THRESHOLD

EXISTING THRESHOLD ANALYSIS

HISTORICAL CONTEXT

DESIGN ITERATION FOUR

SECULAR INSERTION ANALYSIS

SECTIONAL ANALYSIS

DESIGN ITERATION SIX

COMPARISON

REITERATE

FINAL DESIGN

SACRED AND SECULAR

CHURCH + CAFE /RESTAURAN

CHURCH + BREWERY

CRITICAL REFLECTION

LIST OF FIGURES

348
66
386
392
400 

INTRODUCTION 

To clarify the theological context that this thesis operates in, it is important to establish where ARISE CHURCH sits within the spectrum of Christianity.

As a non-denominational Pentecostal CHURCH, ARISE shares a theological approach similar to that of Hillsong CHURCH. Carl Lentz, pastor of their New York campus states: 'We believe Jesus can change your life, I don Jesus ch chang sure were relationship with God. Religion is something you do because you have to. We believe a relationship with Jesus is something you chose to do. We want to be in $\mathrm{CH}$
be there.'1

New Zealand ARISE CHURCH has positioned itself to be accessible to those without a CHURCH background Senior pastor John Cameron often explains thesentiment hat the message (delivery) must be free to change.' This fulfils Bonhoeffer's desire to see the CHURCH shift away from an internal to an external focus. Bonhoeffer considered that religious Christianity had become too much of an insider phenomenon, using language that was irrelevant and unappealing to secular humanity.

ARISE seeks accessibility through the and cecular ser. Undering is the theology that the CHURCH exists primarily to spread the gospel. Exemplifying the evangelical desire, as Jesus commanded his followers, "Go into all the world and preach the gospel to all creation."

This theological positioning informs pssible overlap between sacred and secular activities necessary to an in an architectural detail.

1. Lentz, Carl, interview by Katie Couric. 2013

2. Torgerson, Mark. 2007. pg 15 
ARISE CHURCH are the inhabitants and programme drivers for the design this thesis. As a member of this church, the project is personal. This closeness to the 'client' allows me to understand how the CHURCH functions and interacts with its community. This informs how a specific architecture could improve its function and express the CHURCH's theology through form and programme.

\section{ARISE}

$\mathrm{CHURCH}$

In 2002 ARISE was launched by John

and Gillian Cameron in Wellington.

The first meeting was held in a small

room at Te Whaea Dance and Drama

school. Within twelve years the CHURCH

has multiplied to four campuses across

the country with a total Sunday attendance of approximately 5,500 people. The Wellington congregation gathers in the Mich cow (MFC) seaing approximaty 3,000 (MF) seating approximately 3,00

As a rapidly growing CHURCH, ARISE has planned to start ten additional campuses within the next ten years. The first of which is an 800 seat capacity venue in Lower Hutt planned for completion in late 2014

Although the venues used by ARISE in Wellington achieve neutral in physical presence with the ciry to physical presence with to Pre day a we sunday. The design ARISE, it is posed that the arties on ions is posed hat he architectural ay and sharing a similar theology.

The building created in the design component will enable the three core values of ARISE CHURCH. 'Encounter' personal contact with the presence of God during a CHURCH service; 'Community' midweek small groups 'Cond interscion' and 'Mission,' outworking God's love beyond Church. 


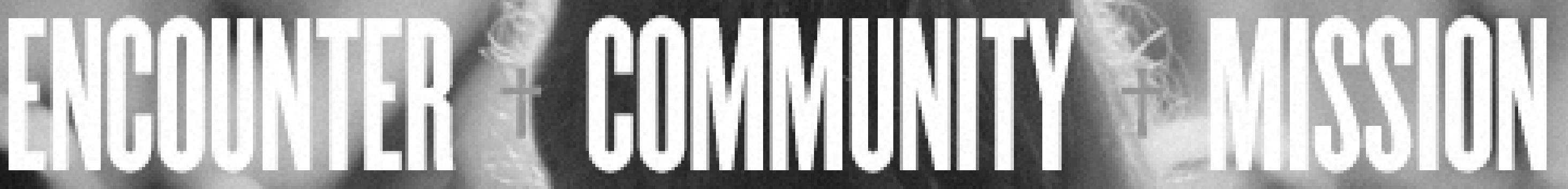


'The presence of God and the influence of Christ are present in everyday life of our world, not just in some 'religious' realm that was somehow distinct from the secular.'John Robinson, Honest To God quoted by Mark Torgerson ${ }^{l}$

The early CHURCH was established by to meet again in homes and civic the apostles of Jesus who originally met structures largely devoid of sacred the apostes of Jess whe originly met structures lared in homes or in public. As the followers notions. Theatres, opera houses and grew in number, meetings were housed halls began to be utilised by evangelical in places of civil assembly, secular and protestant congregations. When in character. ${ }^{3}$ In 313AD Constantine CHURCHES did build, the historical made Christianity the religion of the model of cathedrals was abandoned state. The Christian faith occupied the in favour of more auditorium style original Roman Basilica, establishing an buildings, enabling a contemporary architectural typology now associated liturgy.

CONCERNS

WITH CHURCH BUILDINGS

with Christianity. This model has remained relatively unchanged since then. Following the later protestant splinter, architecture of the church shifted away from a strict architectural cannon. This shift allowed architects an open interpretation of expression, with freedom to express concepts of beauty and divinity.

Continuing this protestant trajectory, ARISE has always met in spaces not intended for $\mathrm{CHURCH}$ use (fig 4,5). However the clear delineation between outside (secular) and inside (sacred), evide (sed by phes sich as St James By the 19th century te or MFC, contradicts the theology of ARISE as open to all. This thesis will of architecture had come full circle to address the need for people to feel as some Protestant movements began welcome in perhaps new environment.

1. Torgerson, Mark. 2007. Pg 17

.Kilde, Jeanne. 2002. pg 19 

a central architectural proposition

\section{METHODOLOGY}

This design led research interrogates concerned with the current state of architecture representing Pentecostal CHURCHES. This thesis endeavours to develop an architecture responsive to the specific needs of the contemporary liturgy.

stray from a theological compliance. It is important to note this diagram is revisited upon beginning each section within the thesis. This highlights the particular inver. the reader within the wider thesis context.

Outliers (further away from centre line) provide a constant frame of The research is presented in line) provide a constant frame of
chronological order to demonstrate reference in which to inform design.
the inherent irregularity of design The research is presented in line) provide a constant frame of
chronological order to demonstrate reference in which to inform design.
the inherent irregularity of design the inherent irregularity of design Precedent analysis are not localised to
led research. Each design proposition the beginning, middle or end as each led research. Each design proposition the beginning, middle or end as each
responds to the key design constraints responds to the key design cons each proposition also manifested additional lines of research that fed into subsequent design iterations.

Fig. 5 is a process map which graphically documents the process of the thesis. This diagram idocess in the his. This dignam identifies investigations as nodes, these are placed in a linear scale representative of time and pages. The vertical axis annotates outliers, investigations that stage responds to develop
so to do the precedents. on notions of threshold. The process develops ultimately offering a product, as seen in the process image, the circles get larger toward the end identifying larger increasingly focused investigations (fig 5). This led research to bly the secilar and sacred.
Initial design narrows scope anchoring he restions 


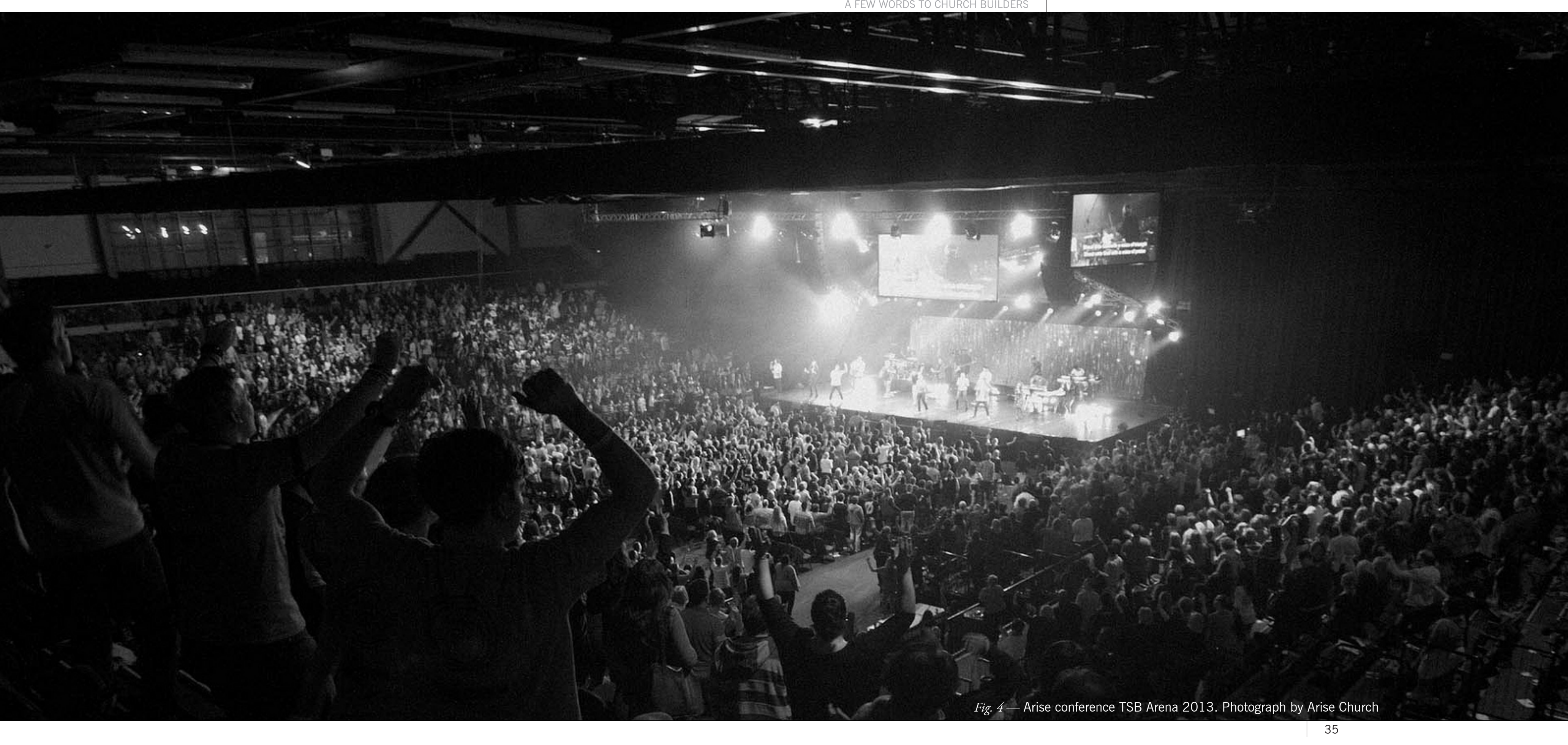



PROCES S 

INTRODUCTION || PROCESS

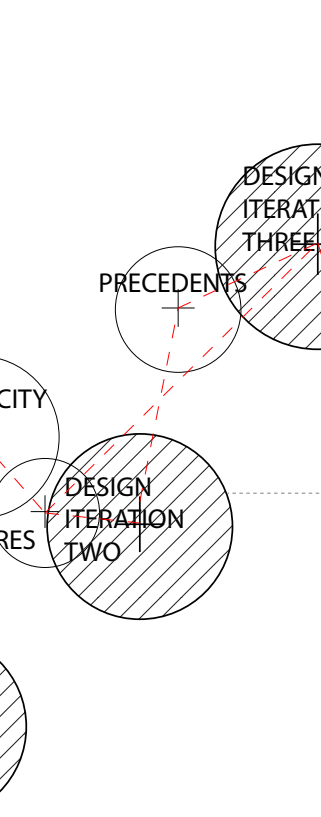

SASSAULT
ARVELOPE IN
ARCHIECTURE

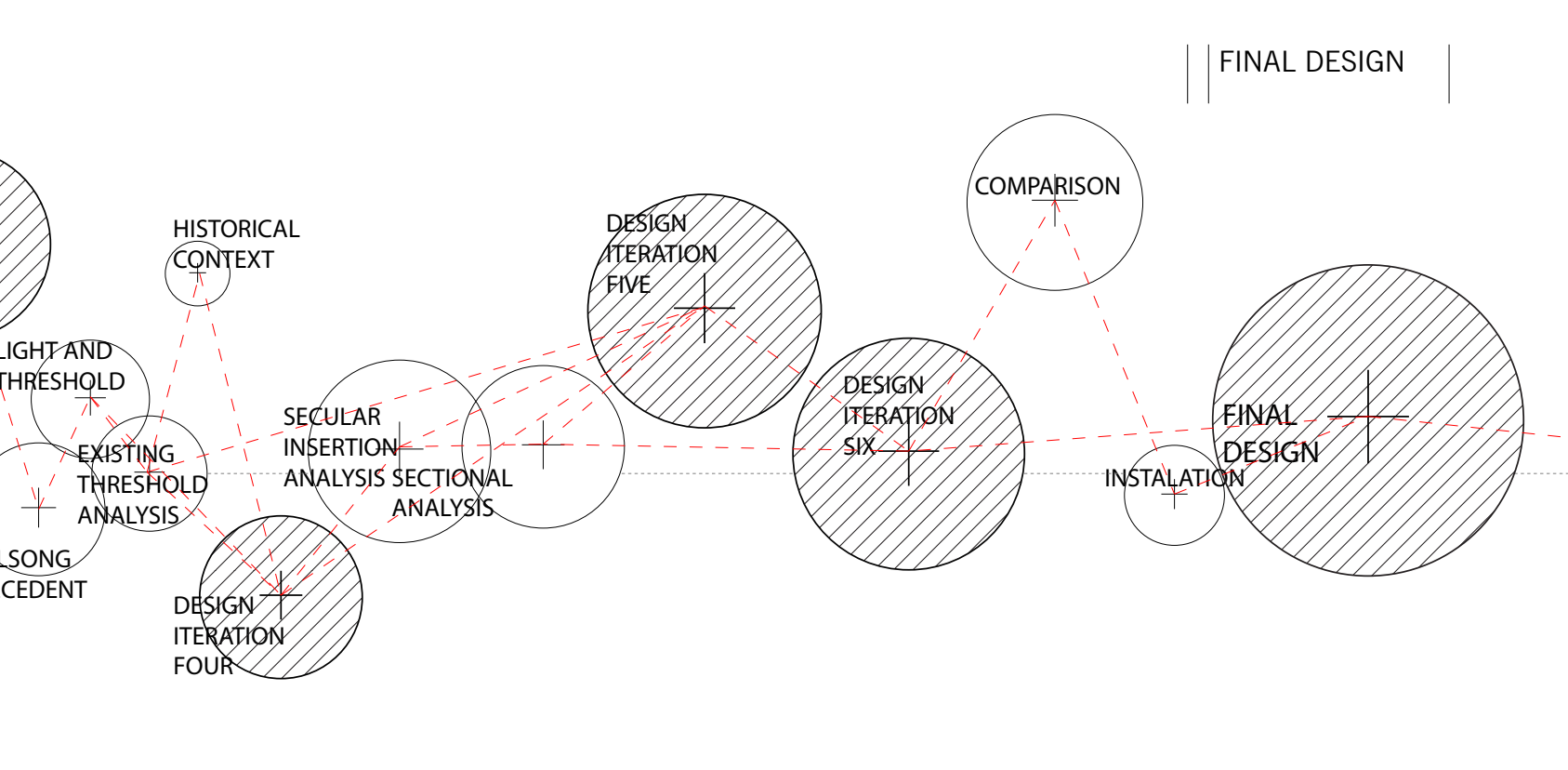





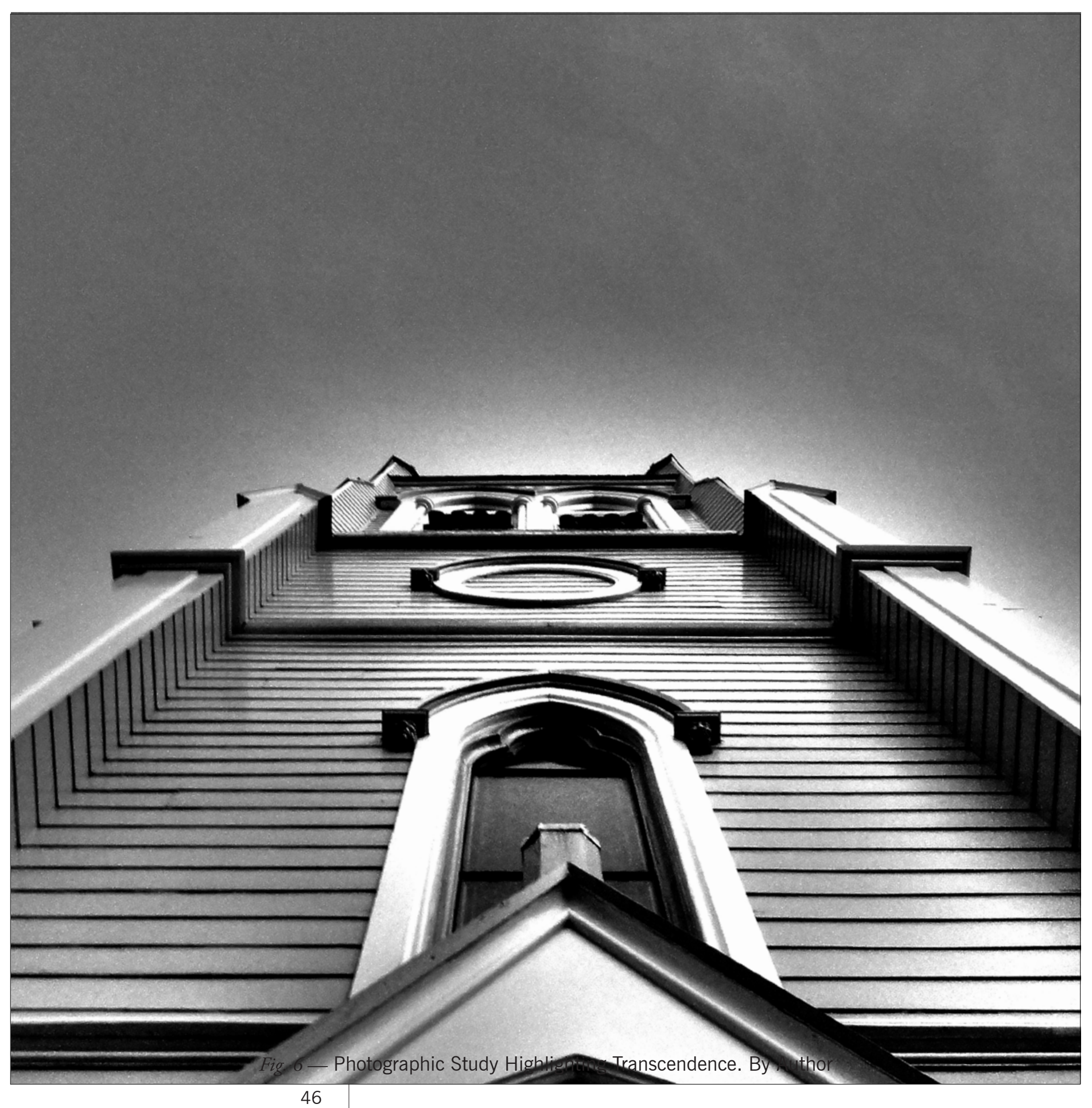

PERCEPTION

O 
"Whatever the extent of the designer's knowing, it is used to find both new knowing and new knowledge. This research through designing is personal and its quality can reasonably be expected to vary."

This initial investigation grounds the two spaces of their influence on the thesis direction, outlining a concern subconscious. The first, a traditional for permeability of envelope and Church and the second, a venue rented the discussion of spiritual objectives by ARISE CHURCH the Michael Fowler through form, characteristics of which Centre (MFC). Photography, blind are seen in the final design. This exercise contour drawing and two maquettes follows an analytical progression are the medium for investigation.

through a series of exercises critiquing

\section{QUALITATIVE ANALYSIS}

Fig. 6 identifies the transcendent nature of traditional Gothic revival architecture. Able to draw the eye upward through verticality of form.

space on the subconscious.

Fig. 7 Represents Wellington's St

Peters, a traditional central city

Church. The square in the sketch symbolises personal consciousness, Figs. 7-8 question immanence (defined as God within us) within the two as God within us winin the two outlined spaces, a traditional ChurchSt Peters, and a rented venue - MFC while the his whe the holing whed in the space is expessed through the Through blind contour drawing the square. The Church has constructed a images illustrate the effect of each separation from the outside (secular)

1. Downton, Peter. 2003. Pg 100 world, limiting its effect on the space. Fig. 8 represents Wellington's MFC Within this secular structure an absence of privacy is revealed in the sketch, evidenced by the continuation of shading through the square that represents personal consciousness.

Fig. 9 identifies the permeability of each structure's envelope. Vertically down the page run two walls drawn in plan, the left represents the traditional and the right the MFC. The sketch reveals the permeable nature of the MFC foyer creating a positive reception to the street.

Figs. 10-11 are collages combining maquette, ink drawings and overlaid sketches. The images overemphasise how each building engages with the city.

Fig. 10 critiques how St Peters appear disengaged with its street corner context.
Fig. 11 expresses the permeability experienced between foyer and street at the MFC. This permeability between inside and outside carries similar characteristics to the receptive nature of the ARISE CHURCH culture. This maquette grounds the notion of efflux- an outward flow from the Church to the secular.

The investigation suggests a receptive architecture toward the secular environment. 

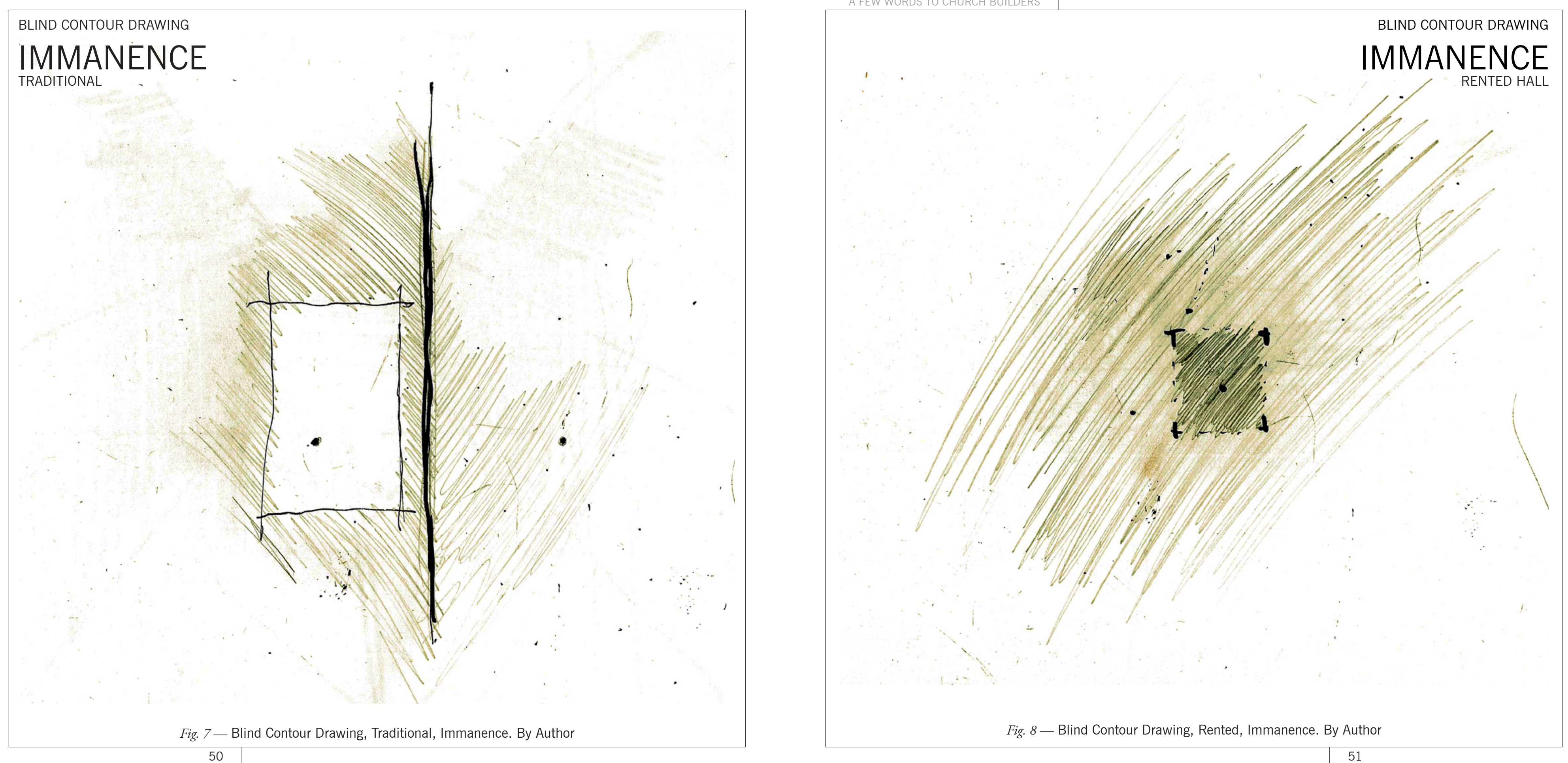

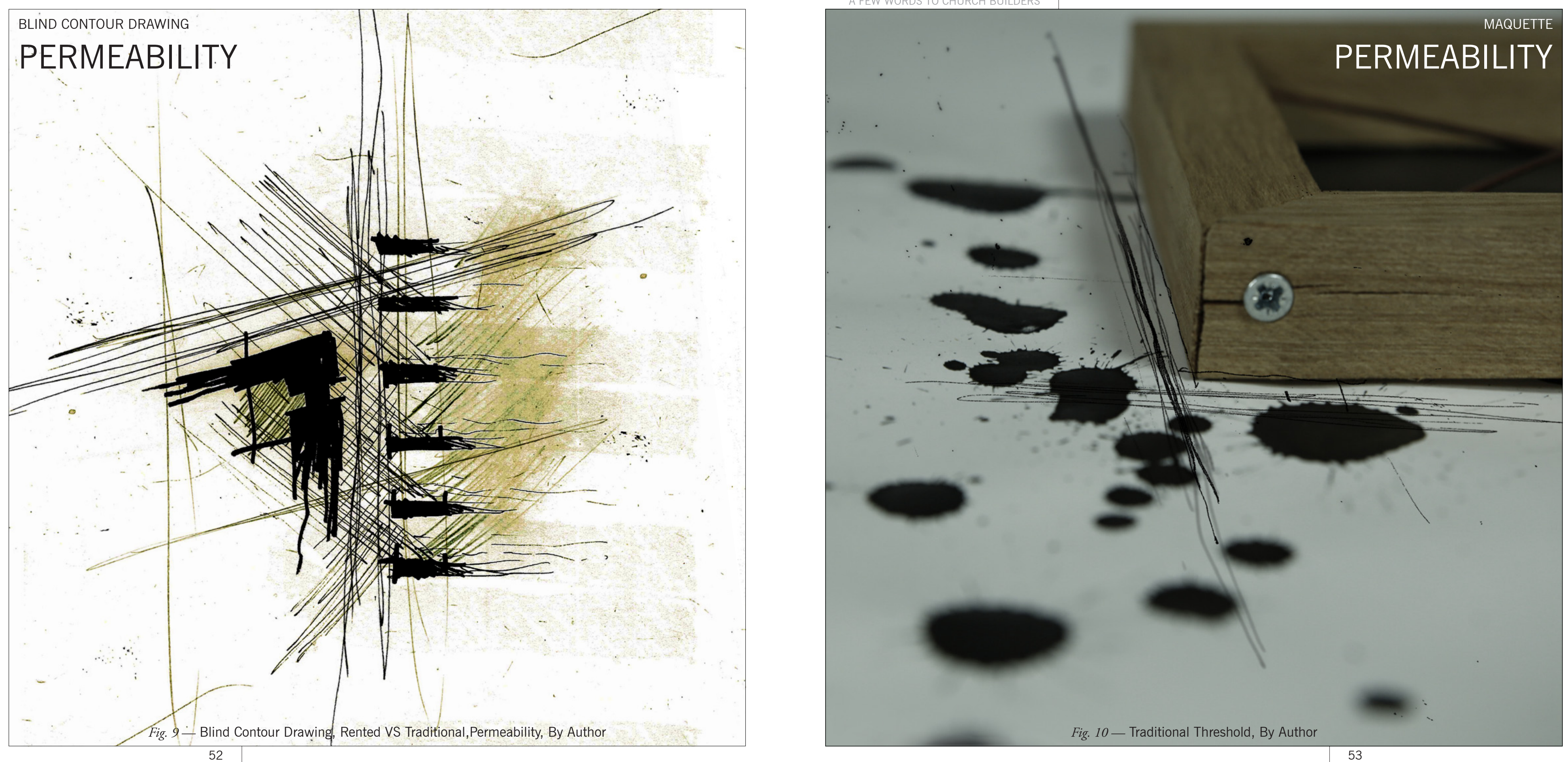


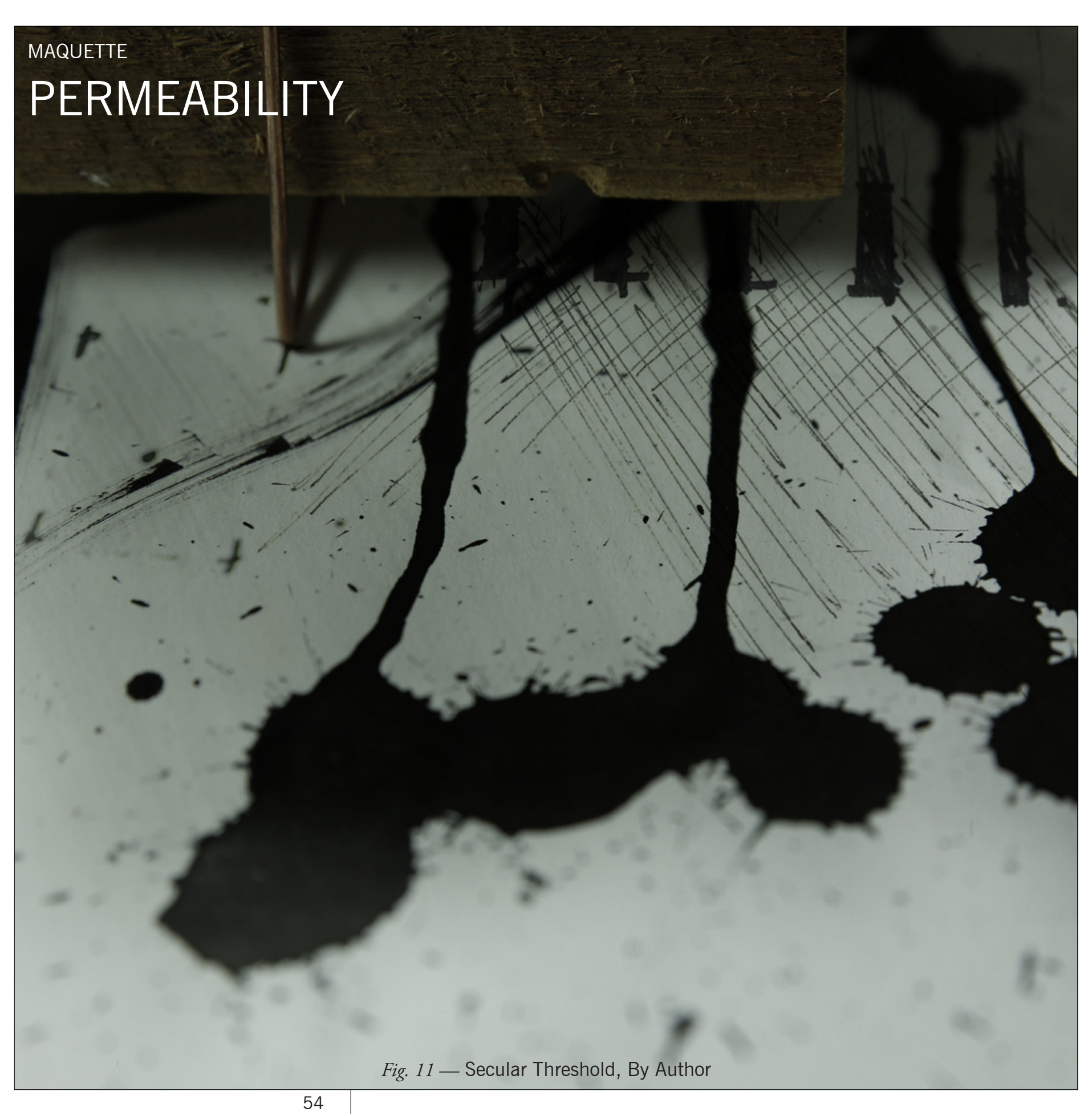

This first drawing investigation

identifies the issue of permeability and

protection between the inside and the

outside, the sacred and the secular. 


\section{THE CHURCH TYPOLOGY \\ CONTIN}

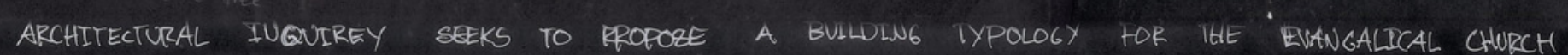

Arse $\rightarrow$ case of udy

INSTINCTIVE DESIGN MOVES 
This section titled 'instinctive design moves' explores permeability of envelope and effux through a maquette and series of experimental drawings. Developing the notion of 'Perception' this section helps narrow and define the focus of research.

Efflux is an interaction between CHURCH and the secular. Permeability is tested and shown trough the following figures.

Figs. 16-17 is a series of short design experiments inserting the notions of 'release' and 'efflux' into existing architecture. This is best illustrated by the water tap metaphor - where 'efflux' is the flow of water, and 'release' is the tap enabling the flow.

Fig. 18 consists of a project map which illustrates the attributes of progress made to this point and projecting forward to 'Envelope.'

Fig. 13 represents the ARISE CHURCH program at a conceptual level, qualitative, the sketch depicts an efflux from a central point - the stage / altar.

Figs. 14-15 progresses the motif from fig. 13 into a maquette - subjecting efflux to enclosure. Symbolic iconography informs the structural design.

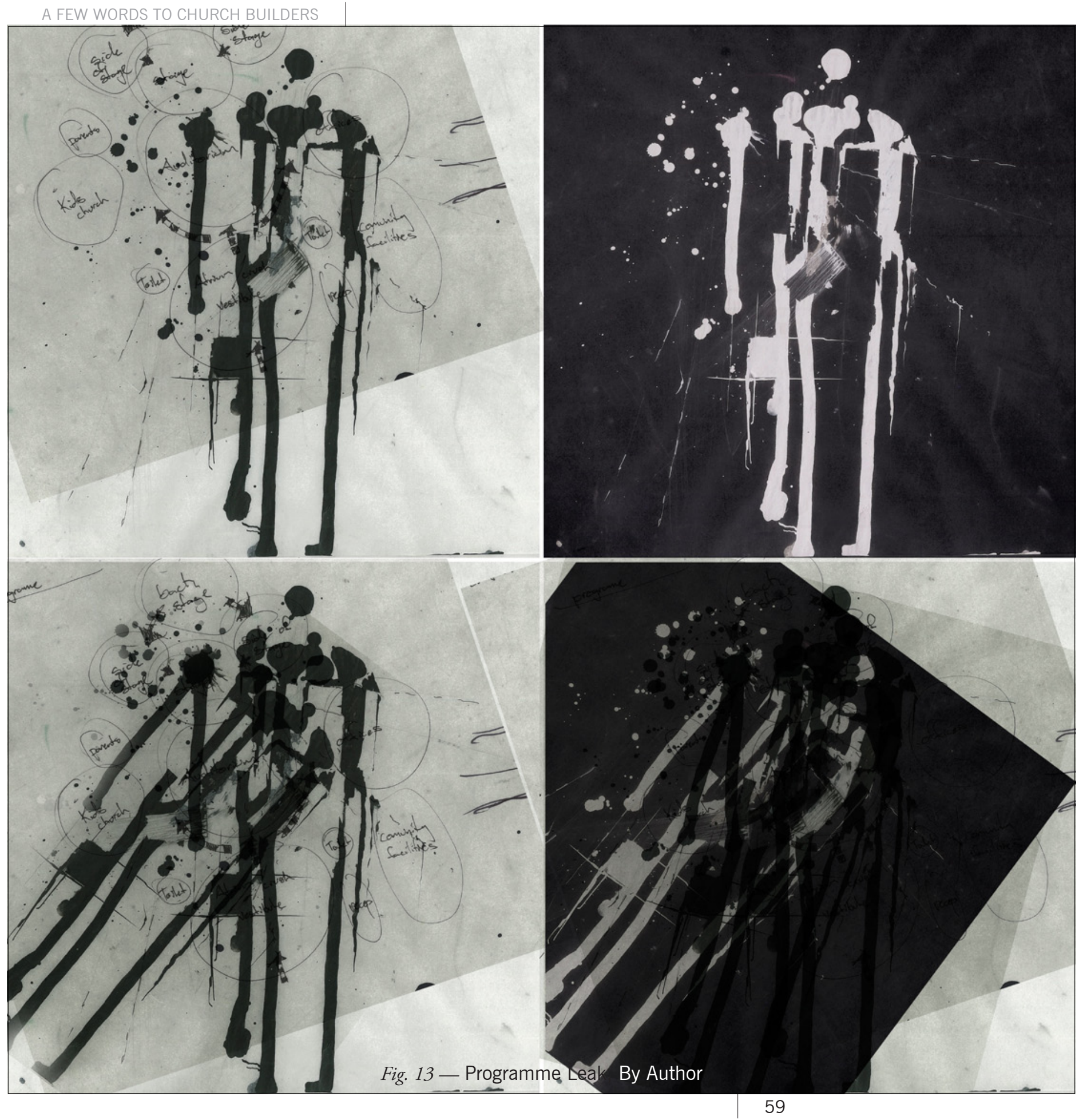



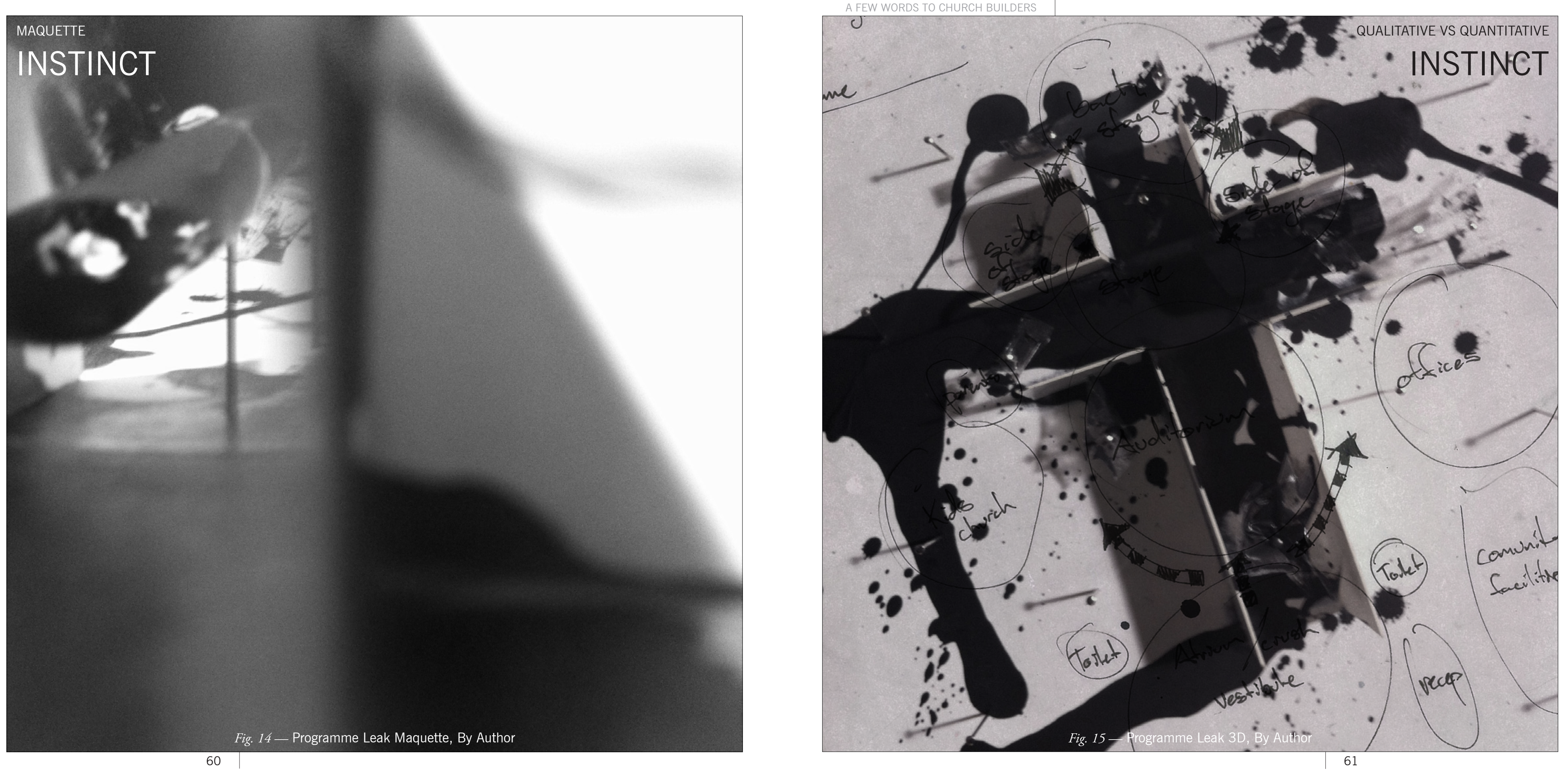

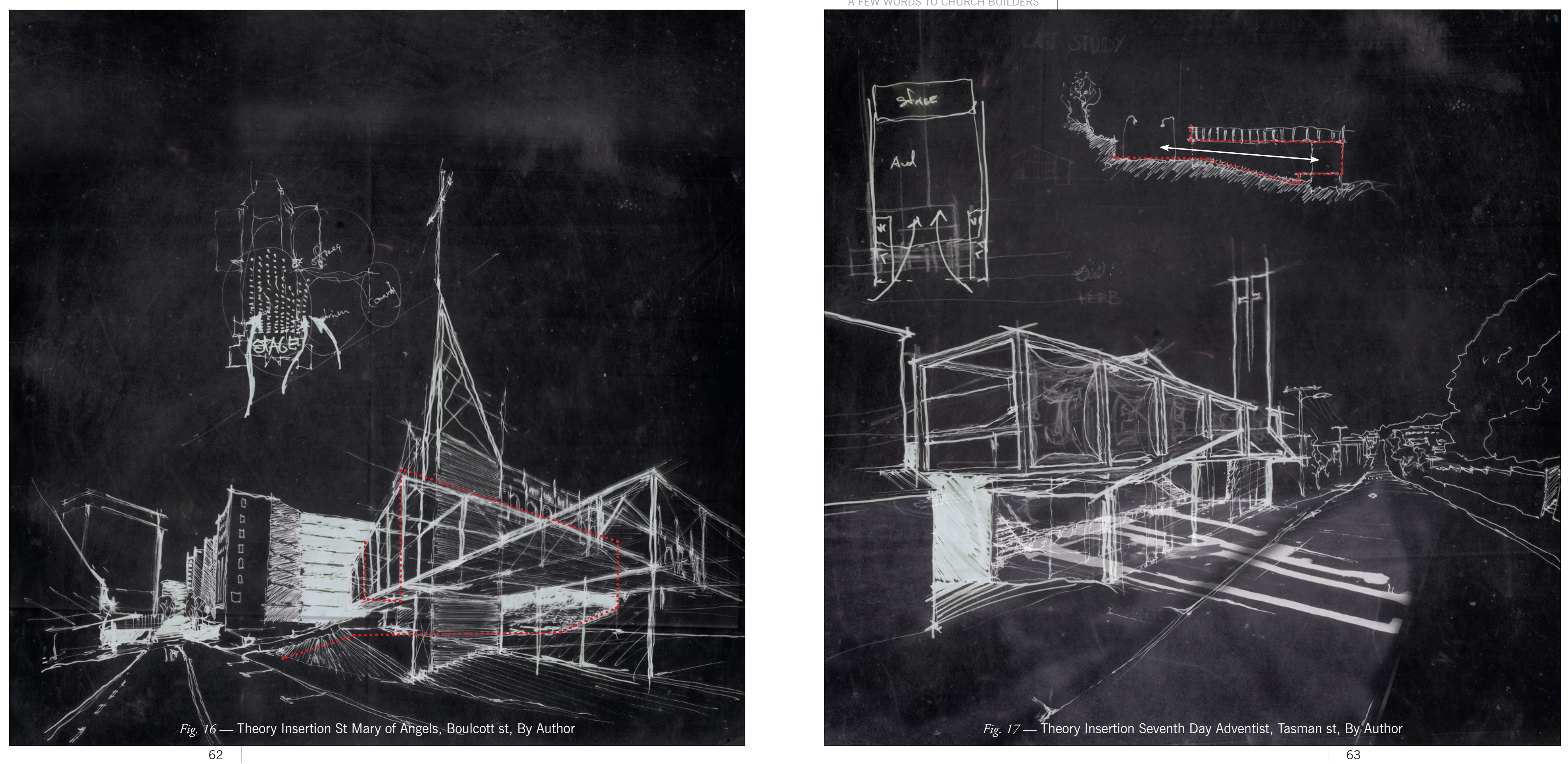


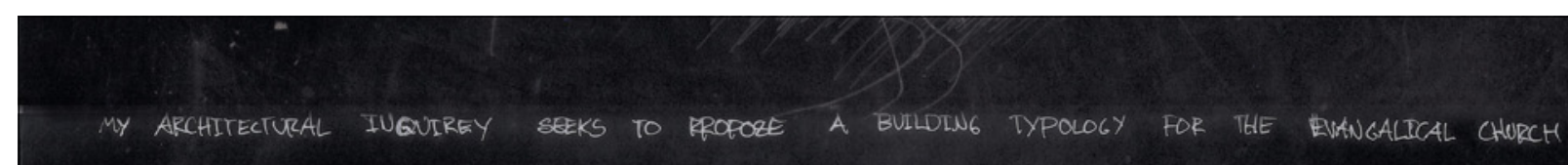

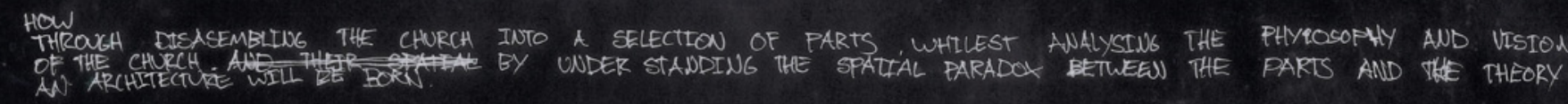

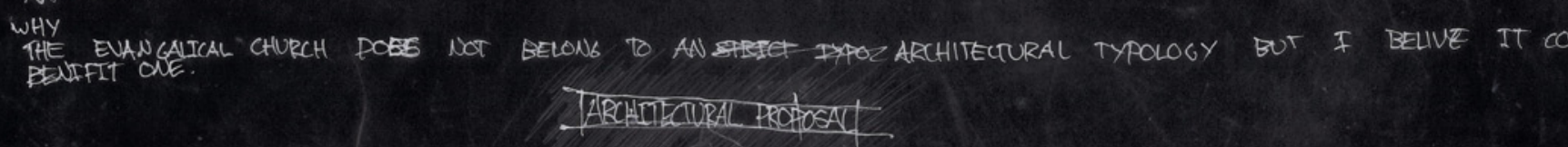

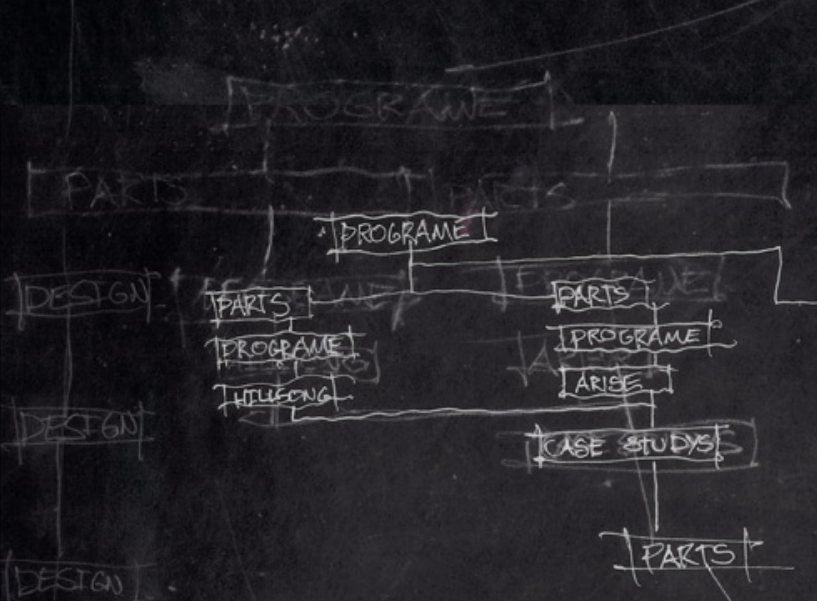

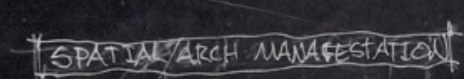

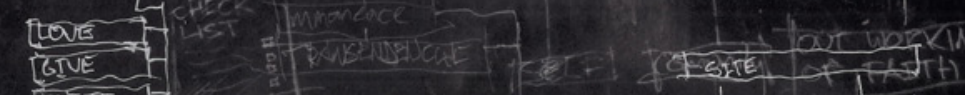

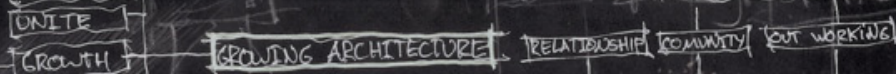

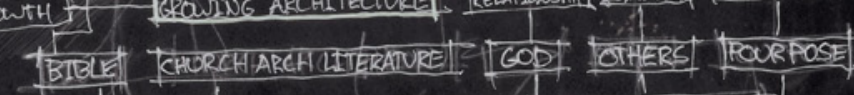
TCONECT WITH TPHLOSOPHY| TISTON ARISEL 7 THEORY

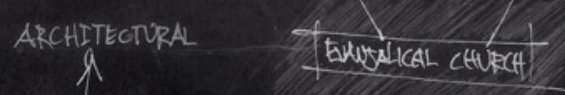

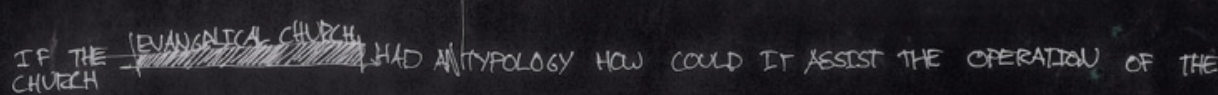

\section{CONCLUSION}

The chapter results in architectural and formal motifs; a permeable relationship between worship space and the street, horizontal in form and strong vertical elements are representative of traditional Church architecture. These attributes raise issues of envelope and its restrictive capacity to limit growth

The concept of the release of efflux is exposed - the envelope as an architectural element becomes central to future design explorations. The following investigation will test characteristics of what constitutes an envelope in response to ARISE CHURCH'S theological standpoint and liturgical operation. 


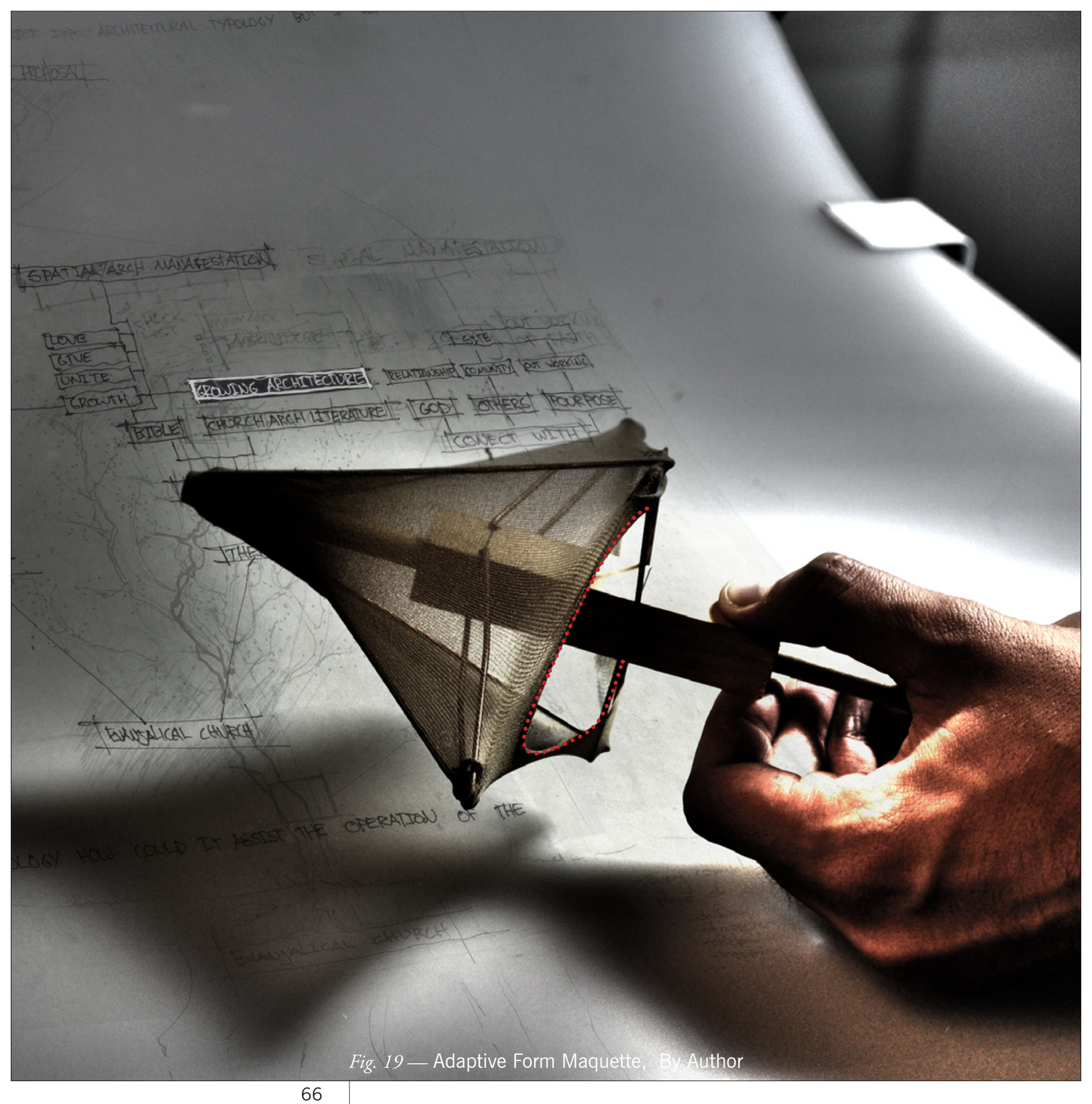

ENVELOPE

(2) 
The Following installation and two and contraction to conceal and reveal. maquette explore the capabilities Liturgy or worship leads to a discussion of envelope to facilitate a dialogue on spiritual objectives of Christian between ARISE CHURCH (interior) and architecture. Notions of transcendence the secular environment (exterior). and immanence will appear.

Some first design principals emerge from the idea of envelope. Expansion

\section{QUALITATIVE ANALYSIS}

ARISE CHURCH prioritises growth and this is symbolically tested through maquetes of fabric and wire structures mich will expand and contract.

Fig. 19 maquette one, develops an architectural language of ARISE CHURCH. An expanding structure manipulates the fabric, metaphorically, opening dialogue between inside and out.

Fig. 20 presents 'maquette one' expanding through images A-C The dialogue between structure

and envelope, interior and exterior, mphasises the inhabitation of Sunday С СиRCH service. This design Surces suggests a means to expand to facilitate Sunday worship and to contract for the emainder of the weeks other activities. This visually links the building's form with its degree of use.

Fig. 21 is an installation seeking to blur a specific interior threshold, by situating a bed in an unused stairwell hat descends from a central vestibul in a house The location of the bed is

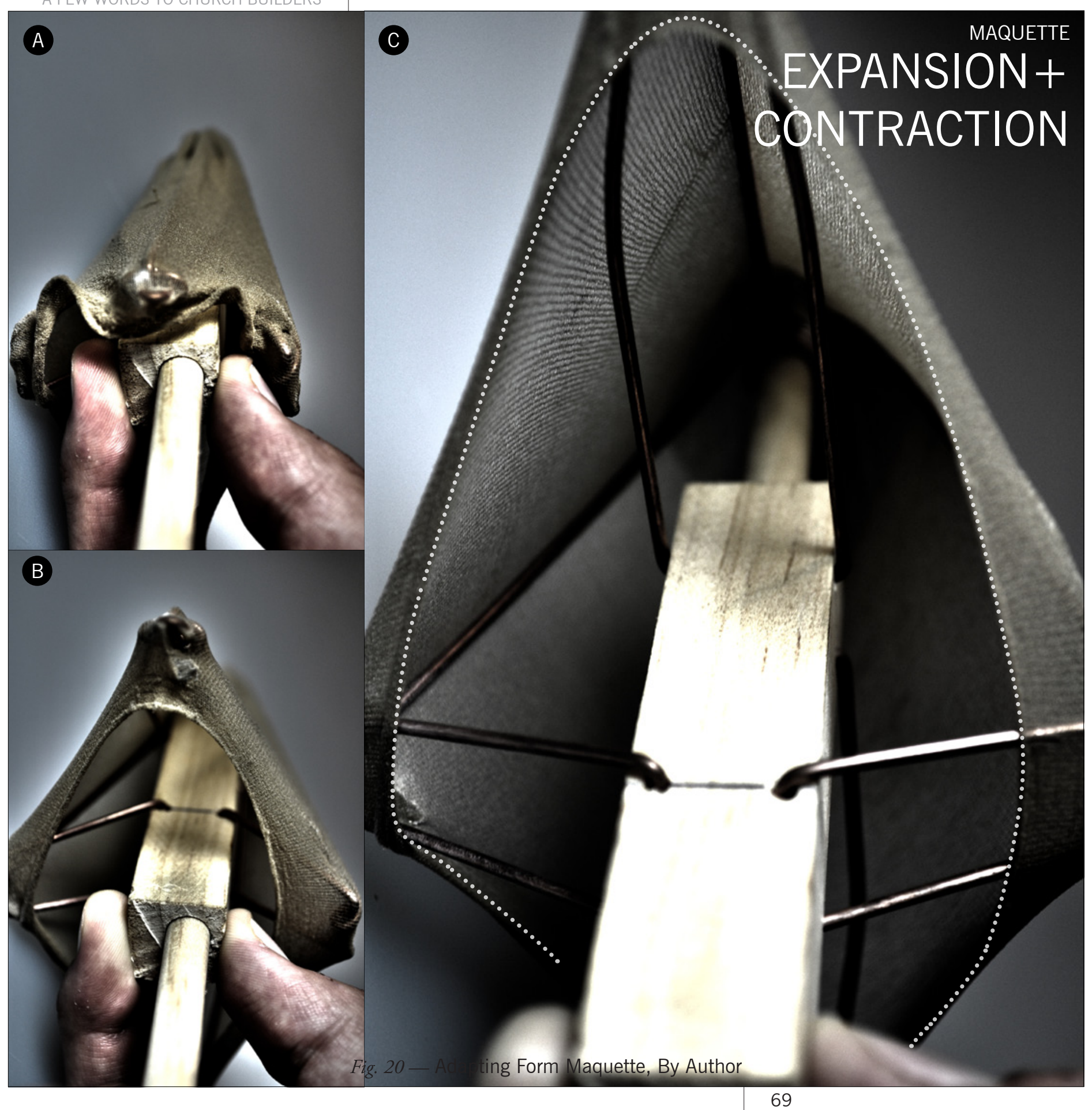


out of sight from the vestibule allowing a blur of threshold through spatial arrangement rather than envelope.

Fig. 22 maquette two, is primarily concerned with creating a dialogue between the worship space and the secular environment rarely afforded within Pentecostal Churches. By engaging the secular visully in the engaging the secto intecture whose interior qualities change a the structure expands or contracts. The interior movement effects the exterior, the two zones are engaged in a mediation of envelope. This dialogue between the internal and external is a relationship developed throughout the thesis, a core foundation for design iterations.

Fig. 23 A common notion within Christian theology is the notion of movement, as it is said a relationship with God is considered a journey. This is expressed through a shifting and moving envelope, ever changing it is subject to human influence.

This chapter highlights design strategies to ensure alignment with theological stance.

Strategy 1: Expansion + Contraction

Inclusiveness is a big part of what defines ARISE CHURCH and other similar CHURCHES. Practiced in any structure these CHURCHES are focused on facilitation of worship and the gathering of a community rather than architectural monument. ARISE uses large venues on Sunday and smaller venues mid week. The expansion and contraction experienced in the change of venue in exposed by chane of venue in exposed by maquetes, each expanding and the congregation. The relationship

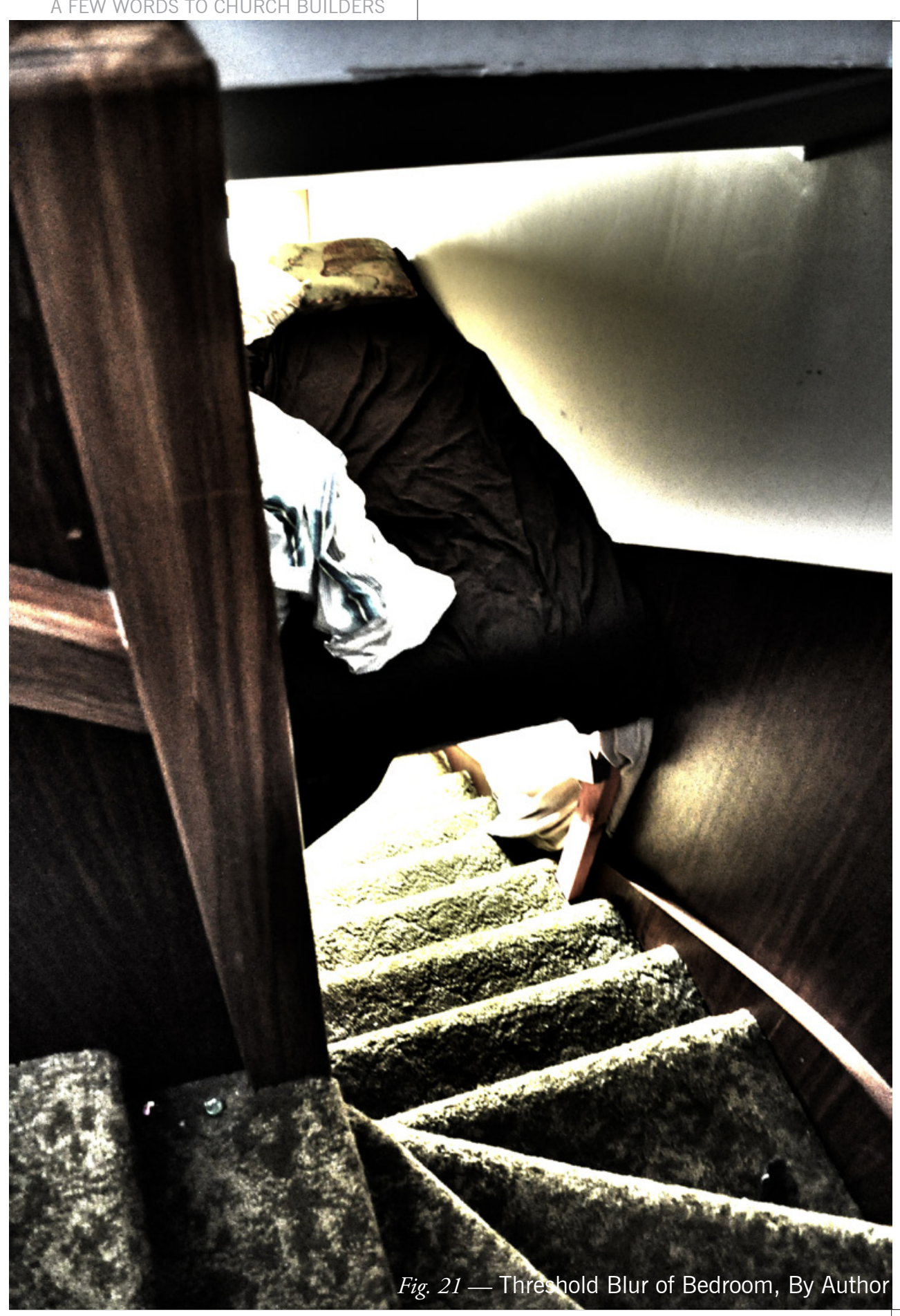


between Olson Kundig's architecture and this investigation is their mechanical structures growing and shrinking, opening and closing.

Strategy 2: Conceal + Reveal

Curiosity can evoke a desire to investigate. The interplay between the release mechanism (tap) and the efflux (water) is a dialogue secn willinux (mas is a dis maquetres. The transparent (tap) allowing a greate reveal of interior space and structure (efflux). Interior and exterior are able to engage through envelope.

The maquette Fig. 22 describes enclosure to differing light qualities of envelope. The interior quality is exposed. Mechanical structure promotes a cause and effect proming between the occupants

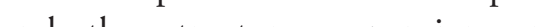
and the strese contraction influence the concealing and revealing. The skin and structure are engaged in a dialogue with the occupants (Fig 23). This maquette represents (in 23). This maquette revealing and concealing nature, the skin and structure change dependant upon capacity.

Strategy 3: Release / Efflux

Envelope and form here attempt to affem Chist Christ present in every day life of our

The maquetre hrough por the shifting envelope seeks to release the church to the secular. The maquette at full expansion reveals interior programme through fabric pulling away from the ground. Threshold (precedent Olson Kundig's architecture) changes form and envelop to reveal interior

Figs. 24-25 Maquette 'two' shown in plan and elevation. The structure is

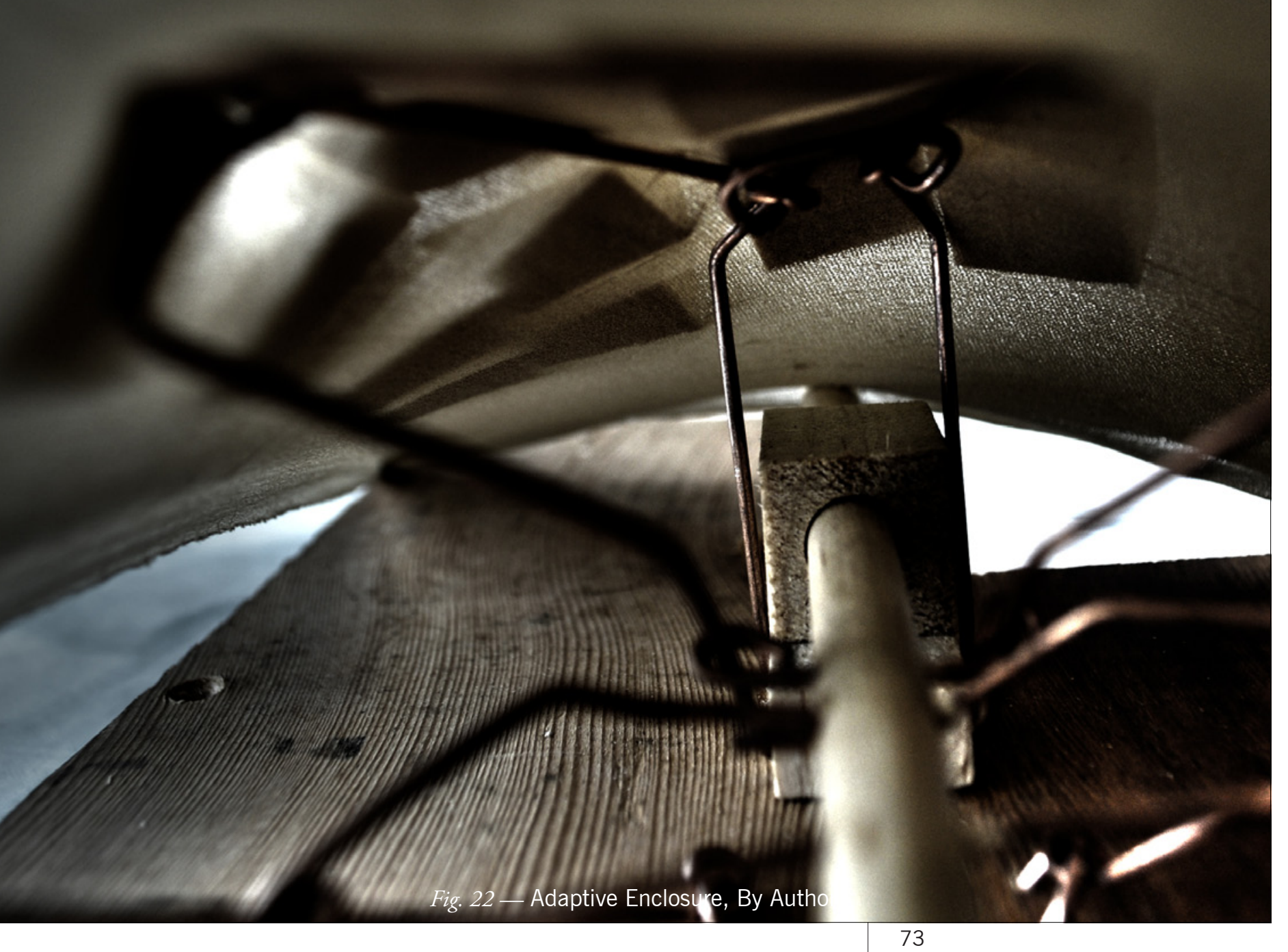


evident through the impression and permeability of the fabric envelope. The sketch overly shows movement of

architecture declares a 'separation' between Church and secular, 'removing external interference.'" This thesis challenges the separation of the СHURCH from the secular. Bonhoeffer Fig. 26 explores the structure seen in stated the purpose of worship is not figs 24-25 in detail this focus on detail to retire from the secular into the informing Olson Kundig's work as department of the religious. ${ }^{2}$

design precedent.

Figs. 27-28, Olson Kundig, Figs. $27-28$, Olson Kundig,
architecture mechanically adjusting

The design intention as referenced by the developing design led research informs a connection between the worship space and the secular. The worship space is not often revealed to the secular environment within Pentecostal Church proceedings. The performative liturgy, contemporary peric and relevant preaching lary itself to accept an engent itself to accept an engagement with the secular envitonment. Borromeo who discusses regulations within Church

$$
\begin{aligned}
& \text { 1. Borromeo, Carlo paraphrased by } \\
& \text { hanno-Walter Kruft } \\
& \text { 2. Torgerson, Mark. 2007, Pg } 17
\end{aligned}
$$$$
\text { Torgerson, Mark. 2007, Pg } 17
$$

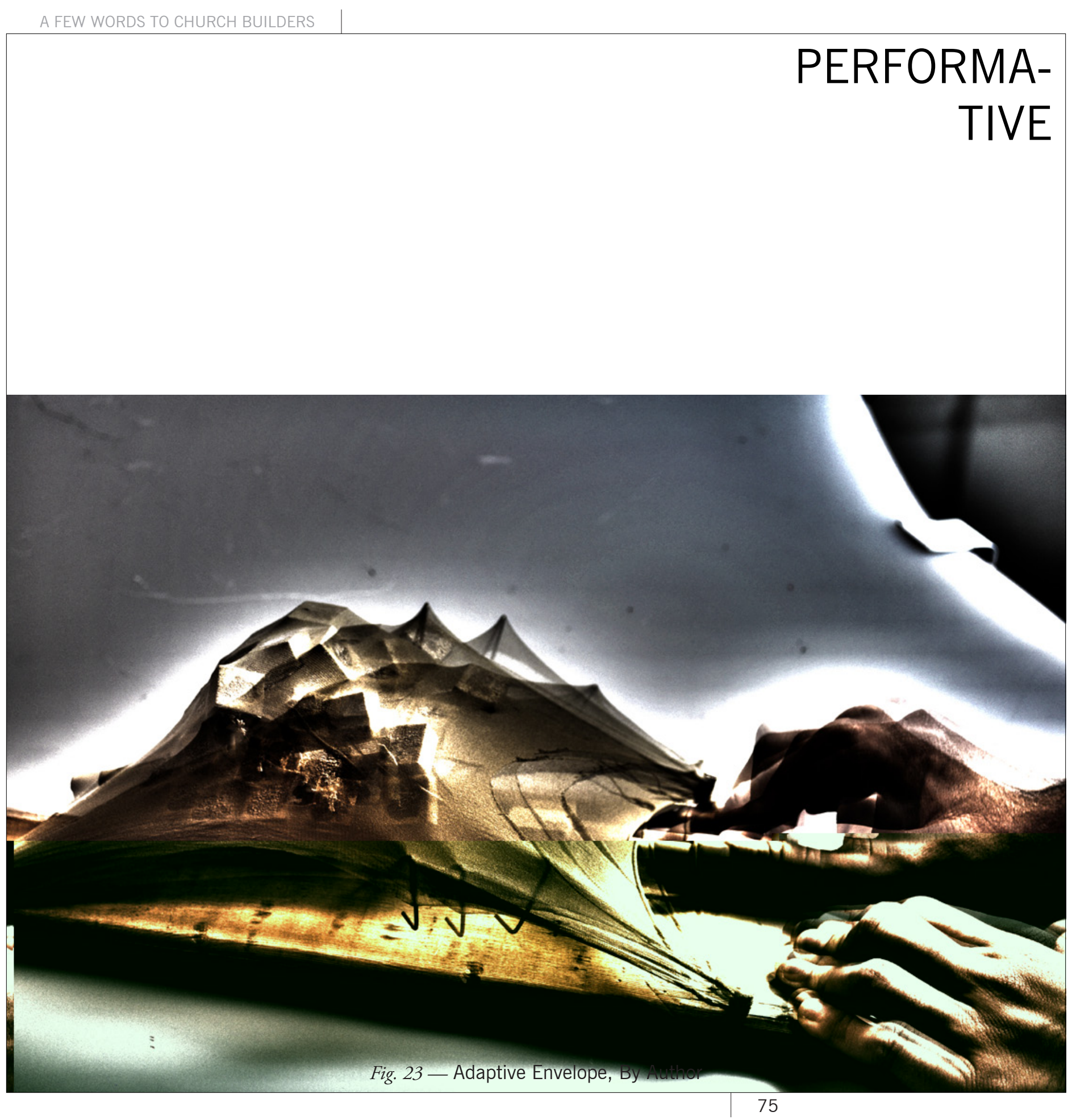




\section{EXPANSION+} CONTRACTION SCALE 1:1

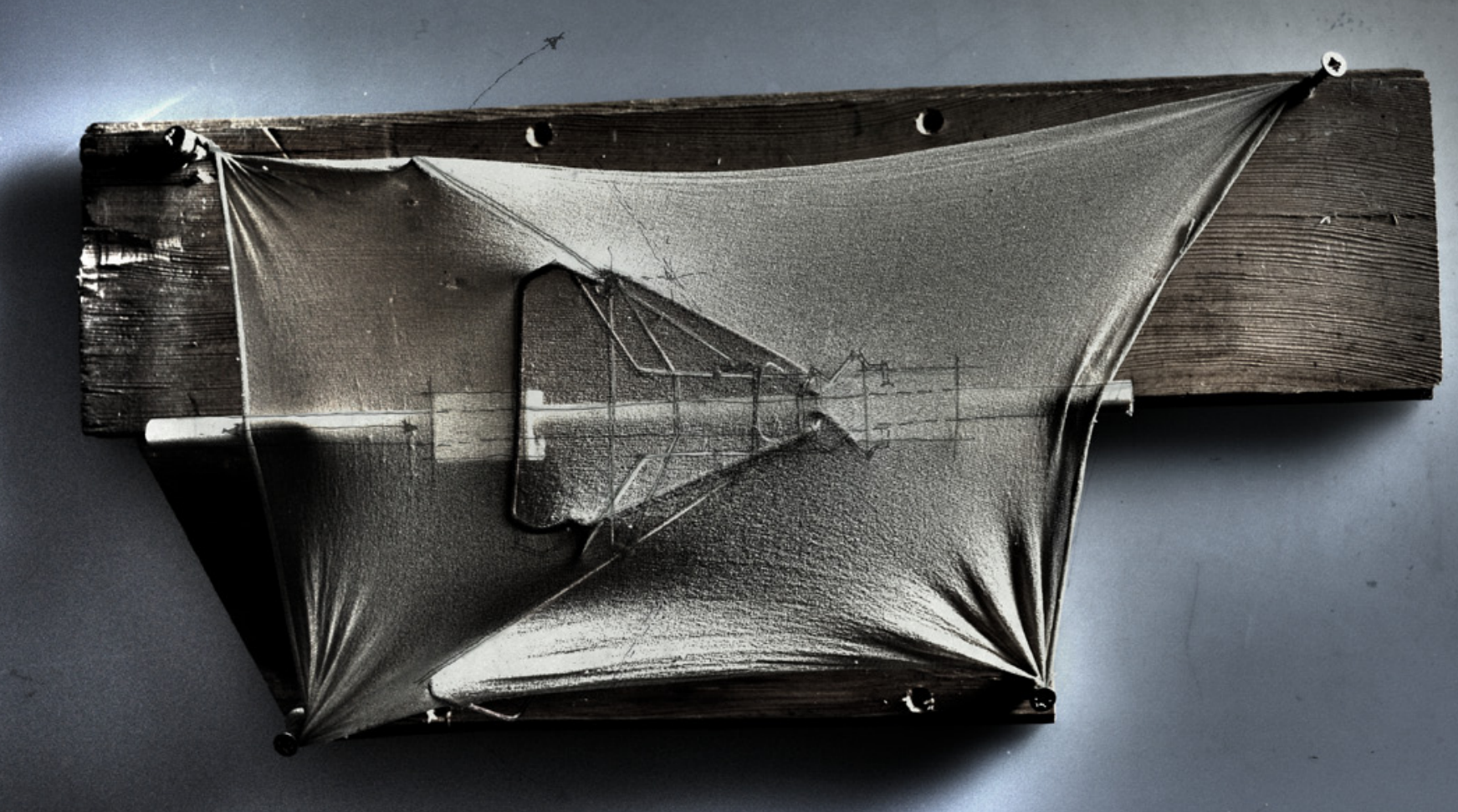


DETAIL

EXPANSION+ CONTRACTION

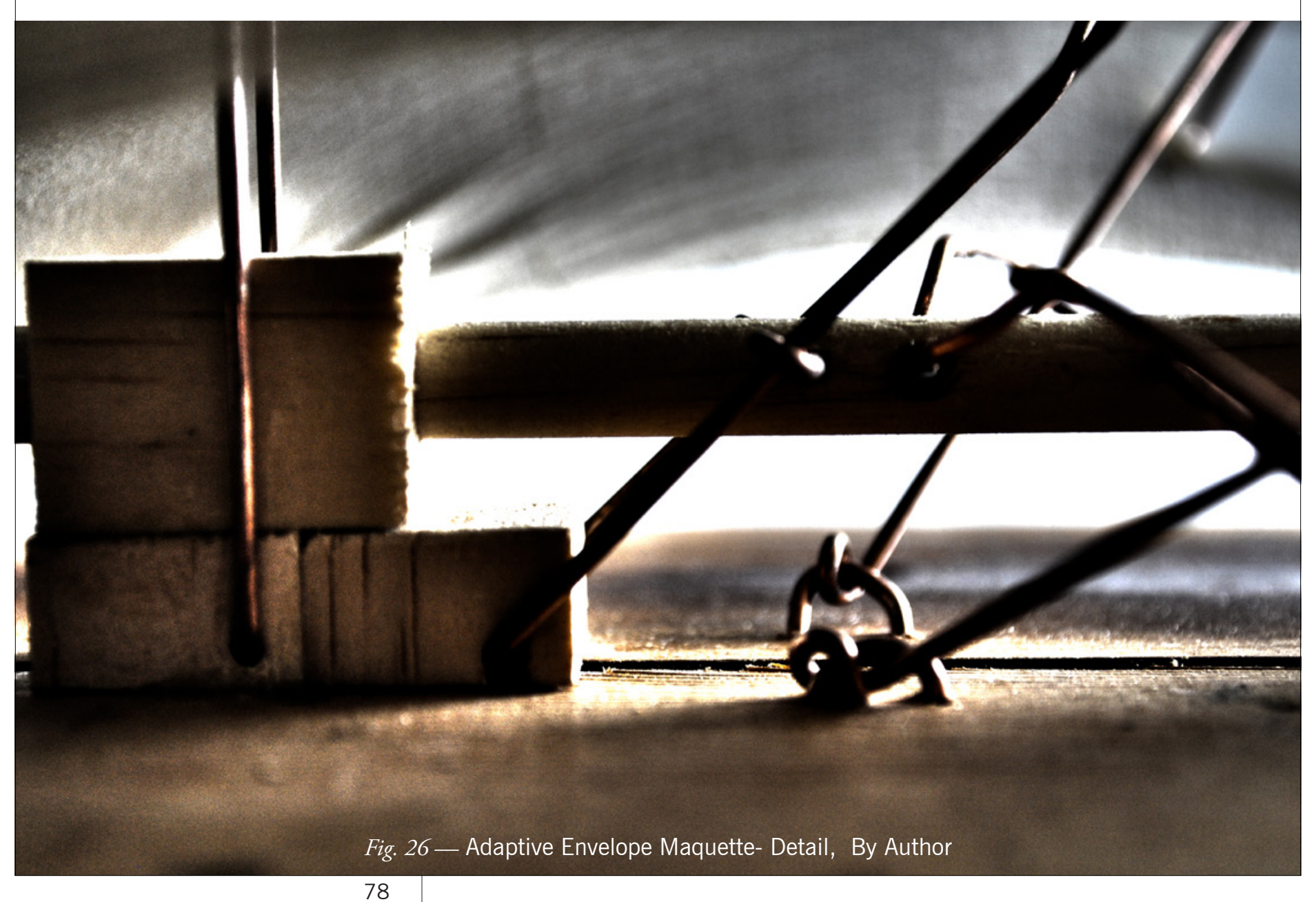

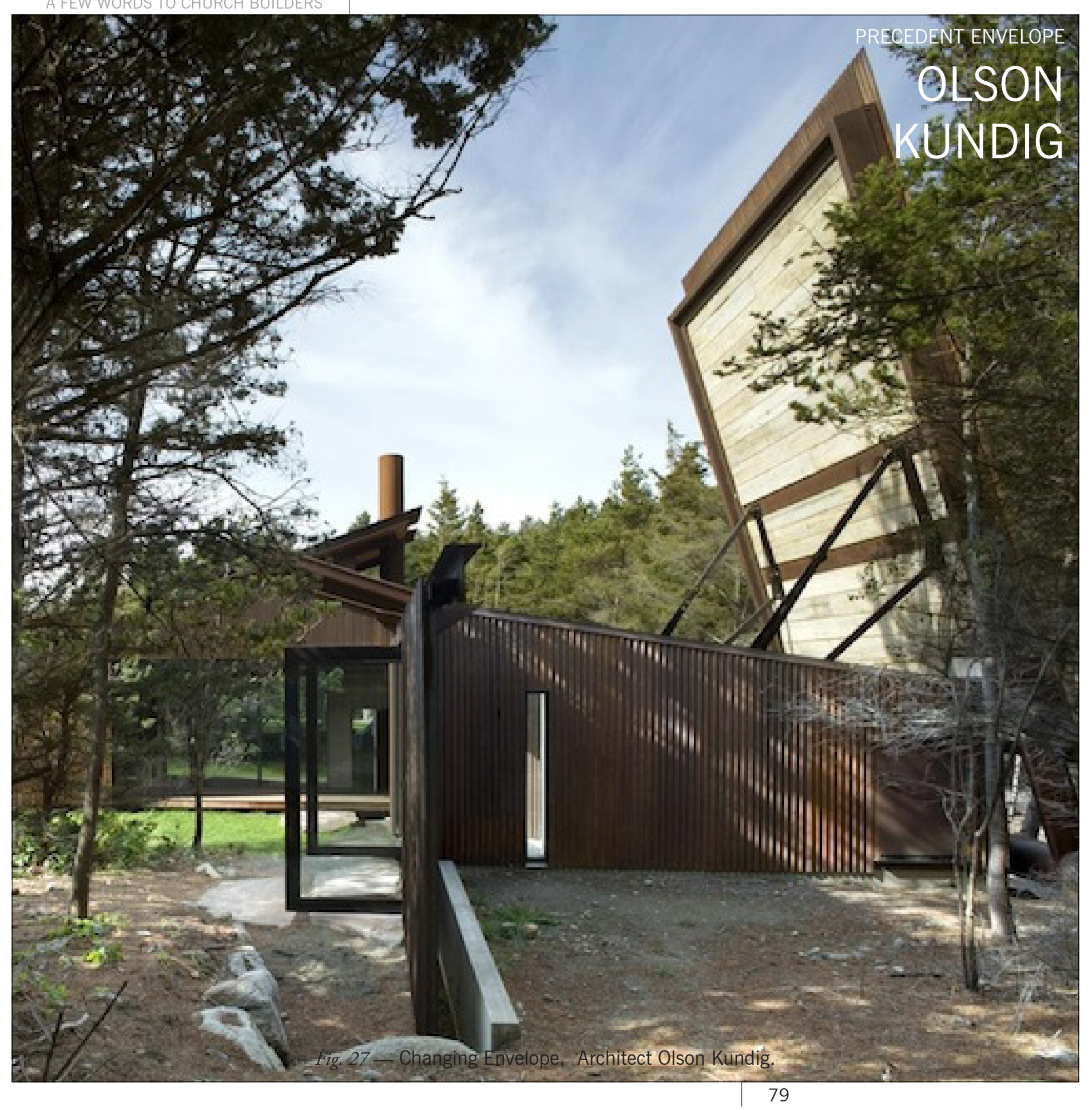




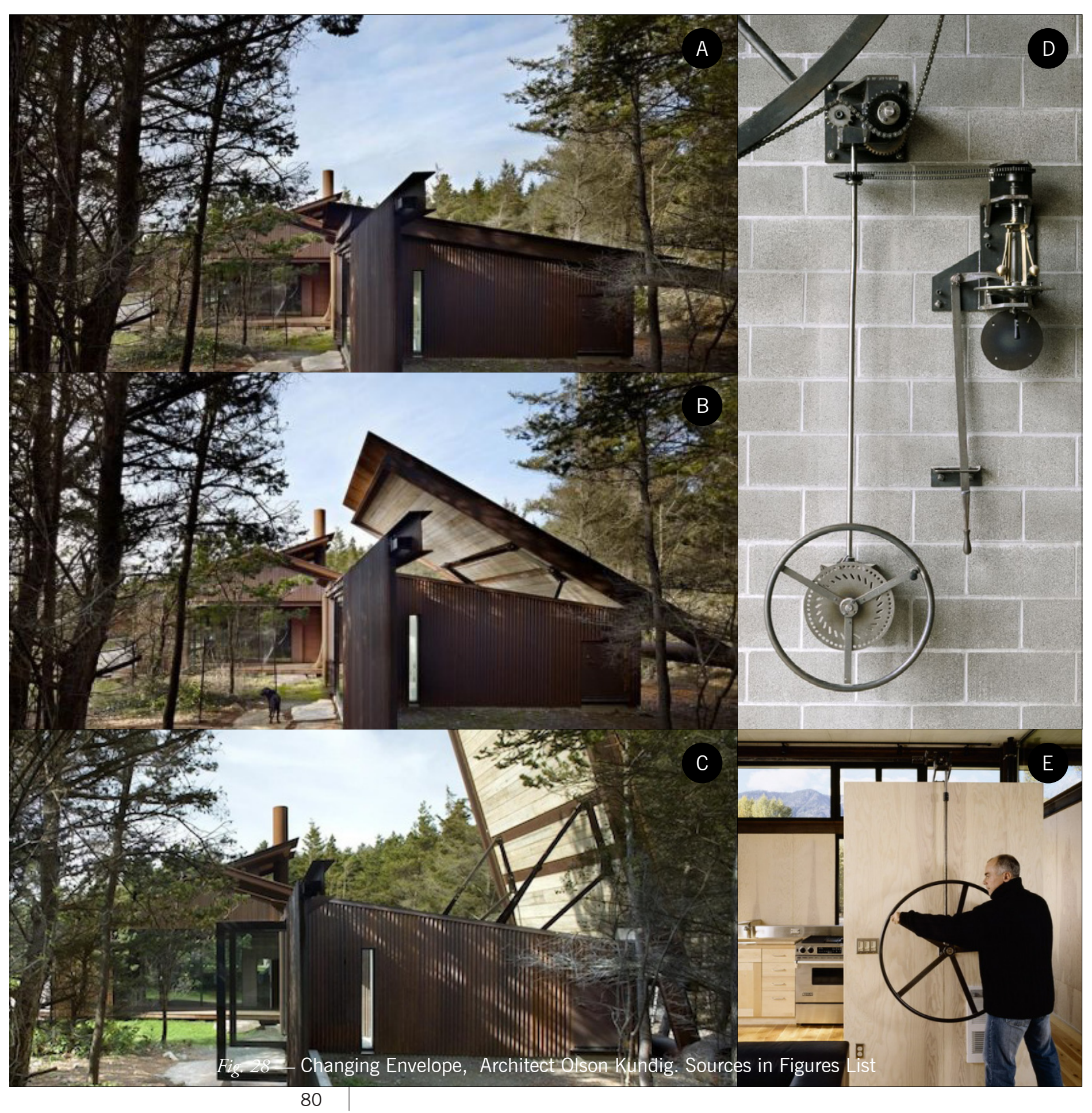

This study outlines a series of design form envelope and materiality. The This stes, devcloped our of he design investigation. investigation. The strategies are expansion and contraction, conceal and reveal and efflux/release. Informed by ARISE and theological context they emphasise the inclusion of the secular within the Church through

FOR M

Representation of spiritual objectives The way in which churches spatially is an age old topic of architectural depict spiritual objectives is an age inquiry. Arise СHURCH so far old topic of architectural inquiry. unconcerned with the built form, has However, the relationship between Christin notions of immanence and the opher Ches med in stuct to be architecture is a more inthential factor resolved or spatially articulated. Mark in the life of society than most people A. Torgerson suggests that there are suppose.' 'Able to influence belief examples of both or either of these systems. ${ }^{2}$ It would appear important if objectives in the existing body of not imperative to accurately represent Church architecture. However, the the priorities of the СHURCH within balance between immanence and purpose built Church architecture. $\quad$ transcendence is yet to be discovered. ${ }^{3}$

1. Sovik, Edward. 1973. pg

3. Torgerson, Mark. 2007. pg 208 
The two research themes, immanence and transcendence are representative of the two main characters of God; firstly God is within us, secondly God is all around us.

Mark A. Torgerson points out that the transcendent and immanent aspects of God characterise a 'fundamental understanding of His nature' which are central to Chisialy ' are central to Chisting "and the en in Chunt to reference in Church design. Torgerson looks at influential theorists including Dietrich Bonhoeffer and John A.T. Robinson who have written on the topic from the 'religionless Christianity' point of view. It is note worthy that this is relevant and closely aligned to characteristics of Arise CHURCH. Religionless Christianity is coined by such characteristics as ' 'relevant' and 'appealing' use of the 'relevan' and 'appealing' use of language Robinson.

'A fundamental understanding of the of $\mathrm{God}$ is important in the consideration of building designs for Christian worship and ministry.'3 The crux of Christianity is the relationship we have with God. Through sending Jesus to pay for our sin God has given man a direct link to him. Prior to the arrival of Jesus there was no such link. The Bible states Jesus is the con cornerstone of Christianity bridging Bonhoeffer exphins " " Bonhoeffer explains the "transcendent and immanent aspects of God's nature are central to the Christian faith"they are made one by Jesus. "What is Christianity, and indeed what is Christ for us today? The time when men could be told everything by a means of words, whether theological or simply pious, is over.'

Architecture is a witness of the CHURCH, 'capable of influencing belief systems of Christians and non-Christian like. ${ }^{6}$ Tools of architecture that

1. Torgerson, Mark. 2007. pg 2

3. Torgerson, Mark. 2007. pg 1

4. Torgerson, Mark. 2007. pg 3

5. Torgerson, Mark. 2007. pg 14

6. Torgerson, Mark. 2007. pg 3
Mark talks about include scale, light, decor, programme and ornamentation he seldom mentions how the urban integration can add or subtract to the performance of the architecture.

The Church typology is full of buildings that lean in favour of one or the other. The Cathedral "by virtue of the monumental and extravagnt aticul' atticulation they enbodied speaks of scale and volume representing This weighing is of This weighting is often justified as a "testimony to the holiness of God, his unique place in our world, and the value that ought to be attributed to him." ${ }^{3}$ Within periods of historical context the typology became rigid and dismissive of a secular interaction. Architecture became a form of worship resulting in a sacred and secular divide. Sacred a sectlor a pallel concep Sacred and secular are parallel concept Mark A. Torgeson appers to par Mark A. Torgeson appears to pair transcendence and the Sacred as on while immanence and secular are the opposite. John Robinson points out in his book Honest to God 'the purpose of worship' is not to 'retire from the secular into the department of the religious. ${ }^{34}$ His writing sets the tone for promoting the elimination of the distinction between sacred and secular. As there is no separation between As th transcendence $\&$ immance as there is no separation betwe as Geds and secis is would be is as if the $\mathrm{RCH}$ existed for itself.

It could be perceived that this sacred separation has filtered through to contemporary views of Church architecture. Mark A. Torgerson in his book An Architecture of Immanence highlights the influence of built surroundings upon our thoughts. It has a poychological input into shap. It our id hoping "The The Chror buildng is a prime aid or " prime hindrance." The building has 1. Torgerson, Mark. 2007. pg 6 3. Torgerson, Mark. 2007. pg 10 4. Robinson, John. 1963, pg. 87 5. Torgerson, Mark. 2007. pg 43 
effect on the vision of the CHURCH" it is so often that the building is contradictory to the acceptance offered by Jesus.

An impulse within 20th century architecture according to Mark A Torgerson was for the CHURCH to emphasise God's immanence over God's transcendence ${ }^{2}$ Over emphe God's tanscen 'God wih emphasis of the notion 'God with us' presents a danger of 'down playing the 'supernatural aspects of the faith' and some groups go as far as reducing Faith to ethics. ${ }^{3}$ Churches began to adopt contemporary building form representative of schools; halls and offices buildings they sought to "connect the pious with nonreligious humanity and attempted to help address the physical and spiritual need of the world" " Torgerson states meeds Christian communities opted for buildings representive of builing reprentative of inance during the "I and the 1970 s into

man is, wherever he is on earth or in outer space. The place, therefore, may turn out to be less important than the presence of the person." T. W. Adams, political scientist NASA.

The discussed relationship between Christian notions of immanence and transcendence as incorporated within architecture speaks only of the Church. But the speaks only of the Church But the same relationship is (sacred) and he ciry (seculs), differ (sacred) and the city (secular), different but intended to be spatially articulated as one. 'But religious building, by virtue of their very identification, will still be considered a reflection (to some degree) of the deity in whose name they are built.

Immanence and Transcendence, the paradoxical relationship in question pxamined hrough arhiecure an be explord throgh scale, light, decor, proganne, space, lines, and sound are the essential components of the experience of architecture and the most profound buildings have captured these moments through thoughtfully orchestrated design. The work we are looking at today has attributes of a universal approach to religion. The buildings are manifestations of the values that are common over a broad scope of religious beliefs, but may a be accepted by secular nonreligiou people. The iconography is frequently people. The icong seciently maintained, but is less emphatic when compared to the altar of a tra Catholic Church in Rome, for example. Subsequently an 'immanent and transcendent balance' is undefined within Christian architecture.

This reading discusses a secularising of the Church form to make the building in which $\mathrm{CHURCH}$ is housed

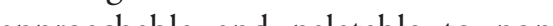
appristians. The discussion onlines Chisting the discre a critique of church architecture in regard to a transcendent and immanent form. These identifiers outline a way in

Torgerson, Mark. 2007. pg 208 which to critique architectural form. The outcome of this thesis is a nontraditional architecture whose form and programme clearly makes no attempt to diagram God, instead discusses an inclusion of the secular in the sacred and the sacred in the secular.

7. pg 43

3. Torgerson, Mark. 2007. pg 11-12

. Torgerson, Mark. 2007. pg 20

6. Torgerson, Mark. 2007. pg 9 


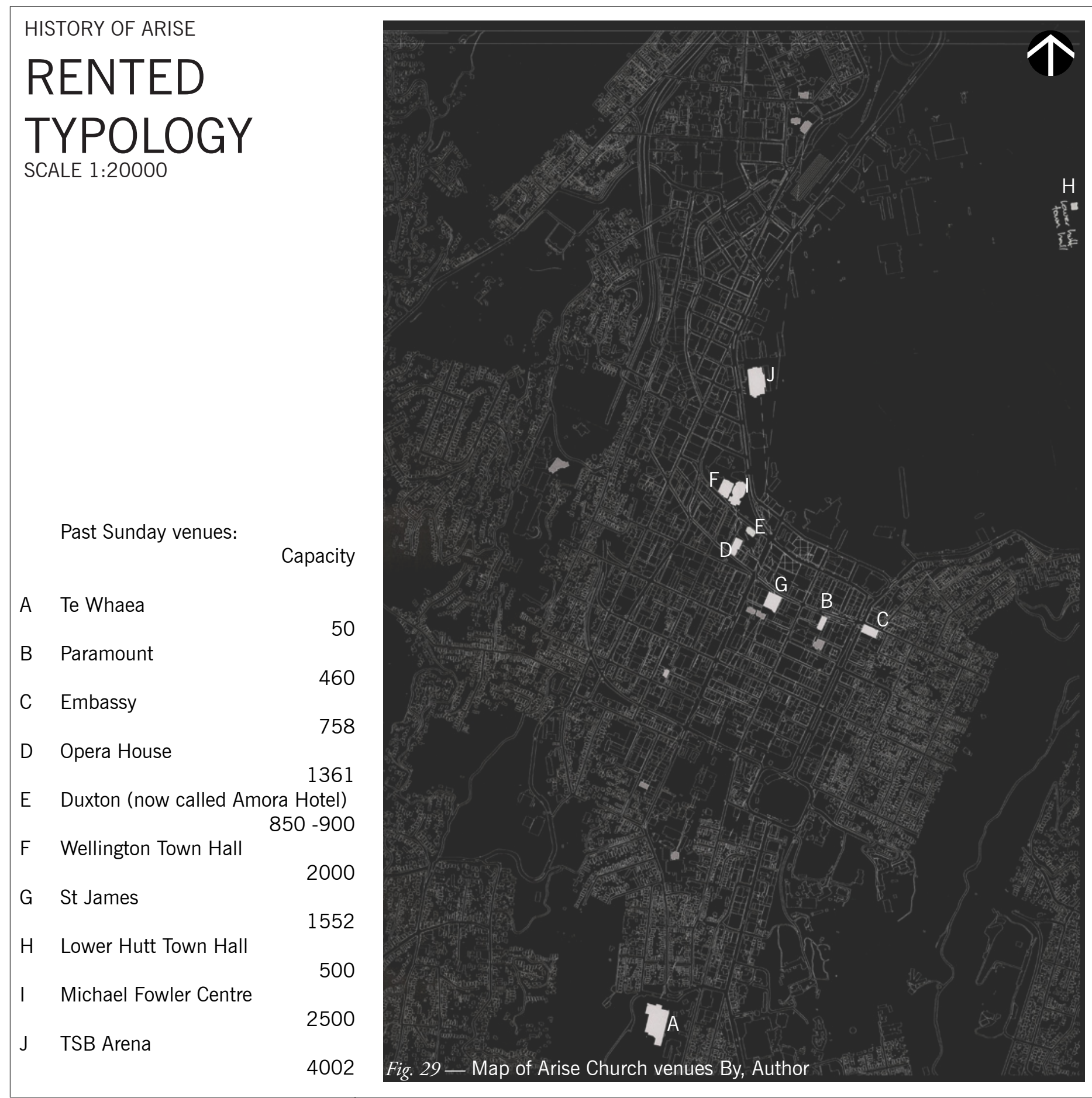

ARISE RENTED TYPOLOGY 
ARISE CHURCH currently and since its

inception has moved from venue to

venue as the congregation has grown.

The movement through Wellington's

urban fabric is localised around central

downtown (Fig. 29).

Until recently ARISE has little to no

focus on the architecture itself. The

church focuses on the facilitation of

event, to enable the CHURCH to grow.

The events currently circulate between

Michael Fowler Centre (MFC), the

TSB arena and the St James Theatre.

Once a year Arise hosts a conference

where all campuses come together and

this is held in the TSB Arena.

The building of a specific Church

building will create a solidified presence

of ARISE throughout the week. The

of ARISE throughout the week. The

selection of site is important to assist in

presence within the city.

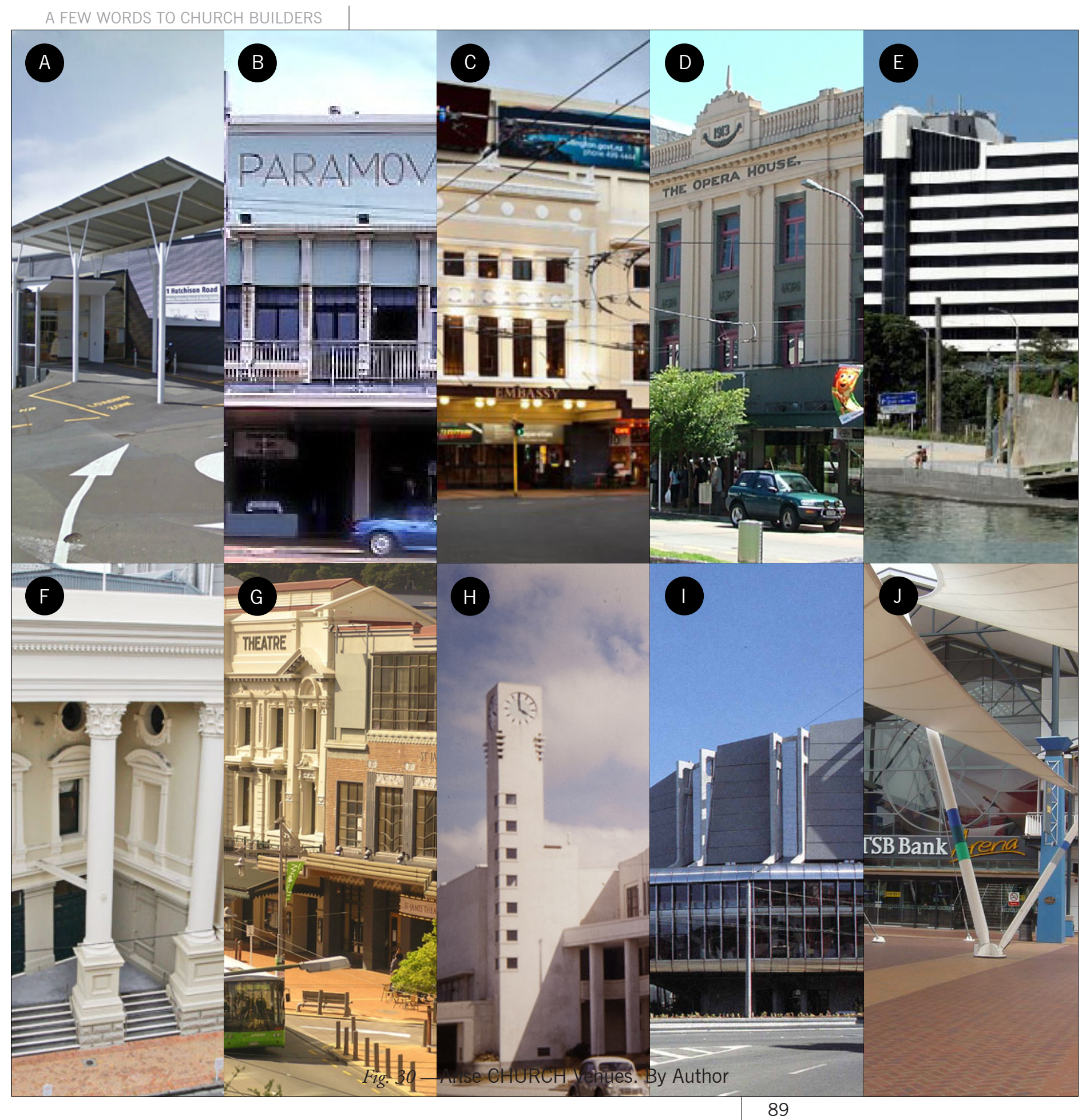




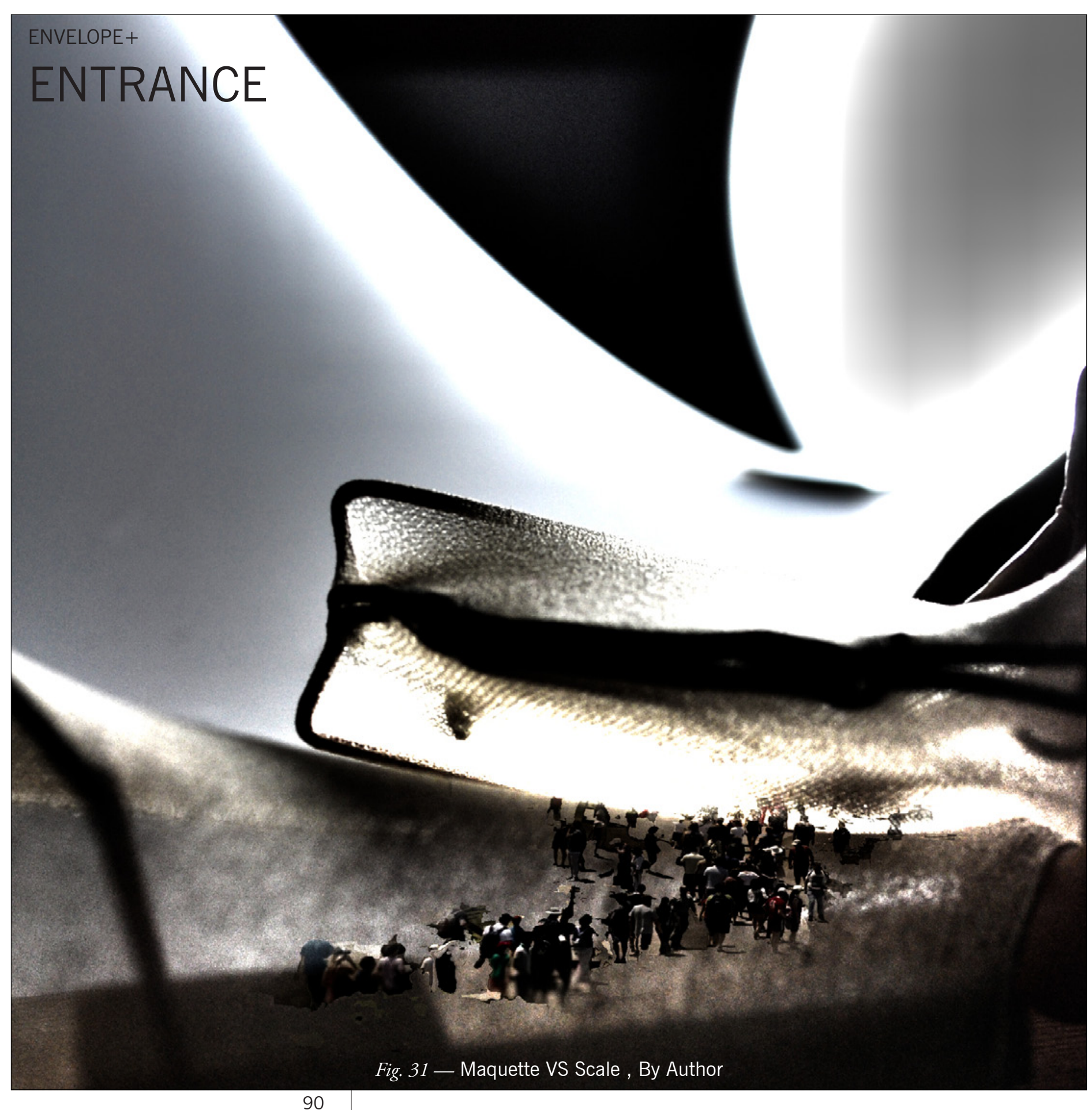

ENVELOPE IN ARCHITECTURE 
Envelope is pushed further through insertion into context. The outcome informs a distancing from literal fabric structures. Channelling design through Wellington's Te Whaea dance and drama centre ARISE CHURCH's first venue, concepts are challenged by an integral part of ARISE's past.

Fig. 31 shifts scale from the macro to ptive, illuminated ill be further explored in the design process.

Fig. 32 inserts Arise (current) into Te Whaea (Past). The drawing investigates the insertion of established design principles. The stretching fabric structure expresses ARISE's characteristics as established in 'envelope,' The drawings explore 'expansion and contraction th expanse and contraction through an sis is sect soly for the site is selccted soley for the purpose of testing the aesthetic effect of an envelope performing expansion and contraction (sacred) within a given 'static' context (secular).

The exercise raised the issue of site and scale of intervention. The next section 'site macro,' attempts to find a site for the allocation of ARISE CHURCH programme in the city.
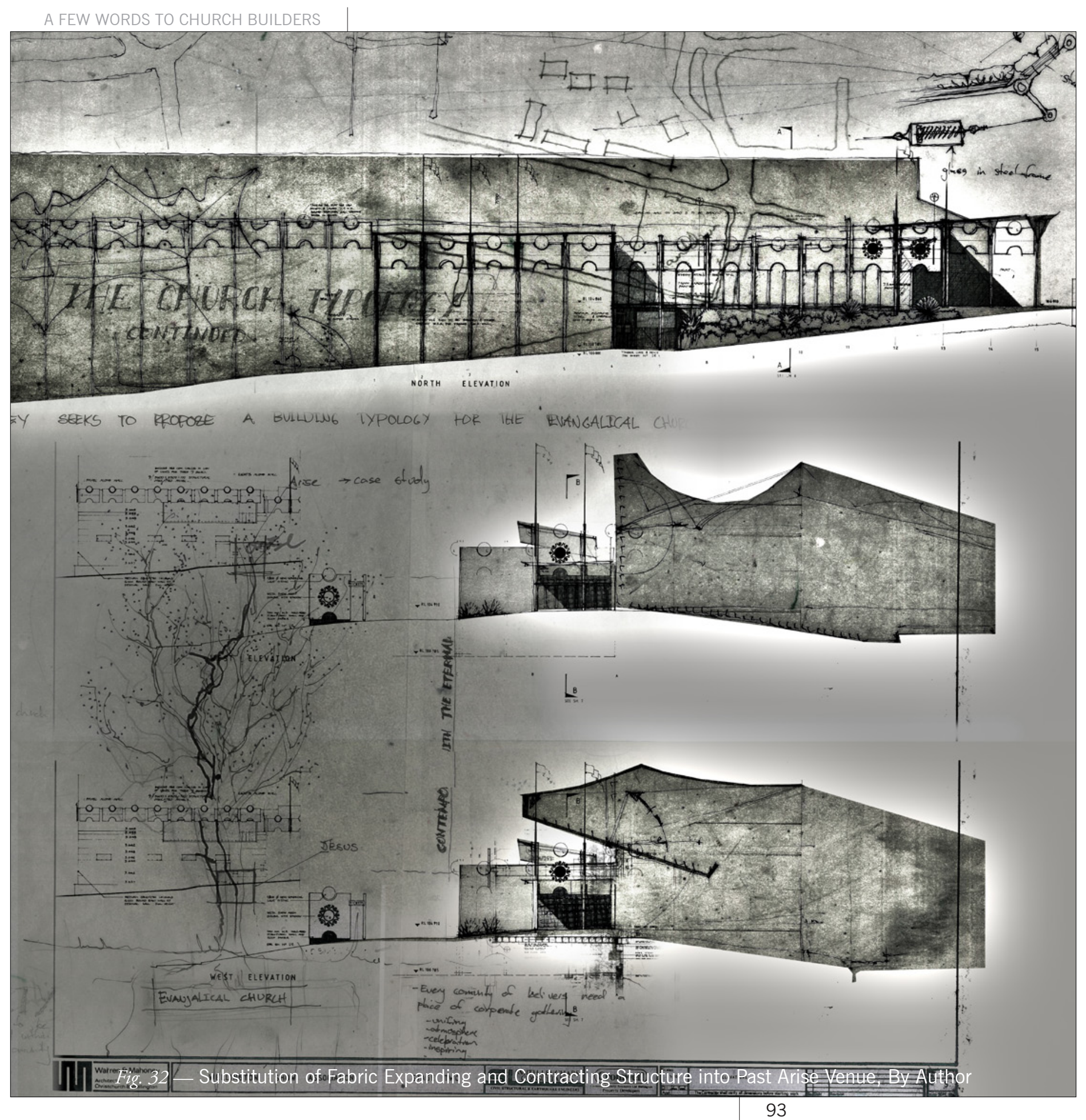


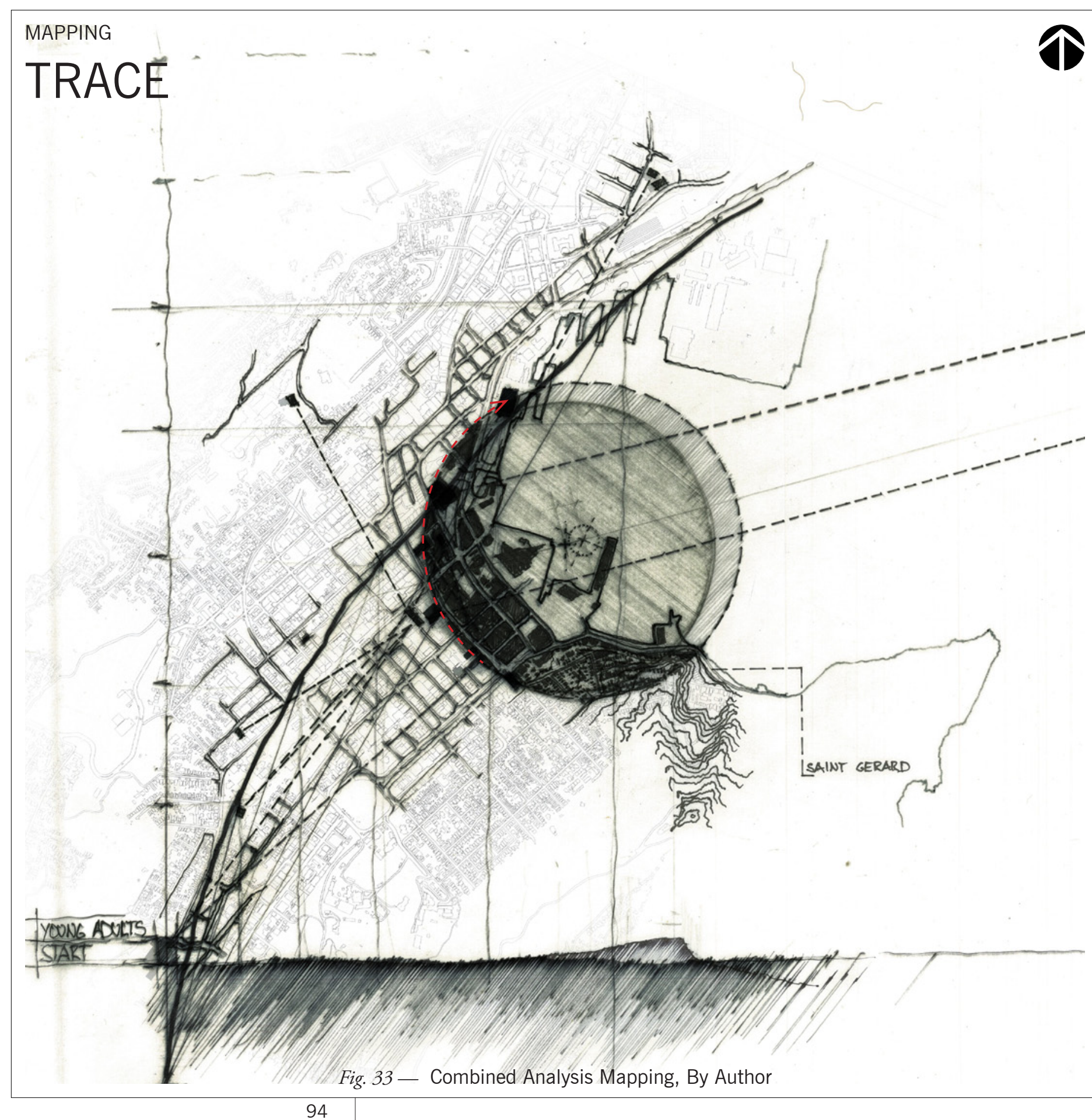

SITE MACRO 


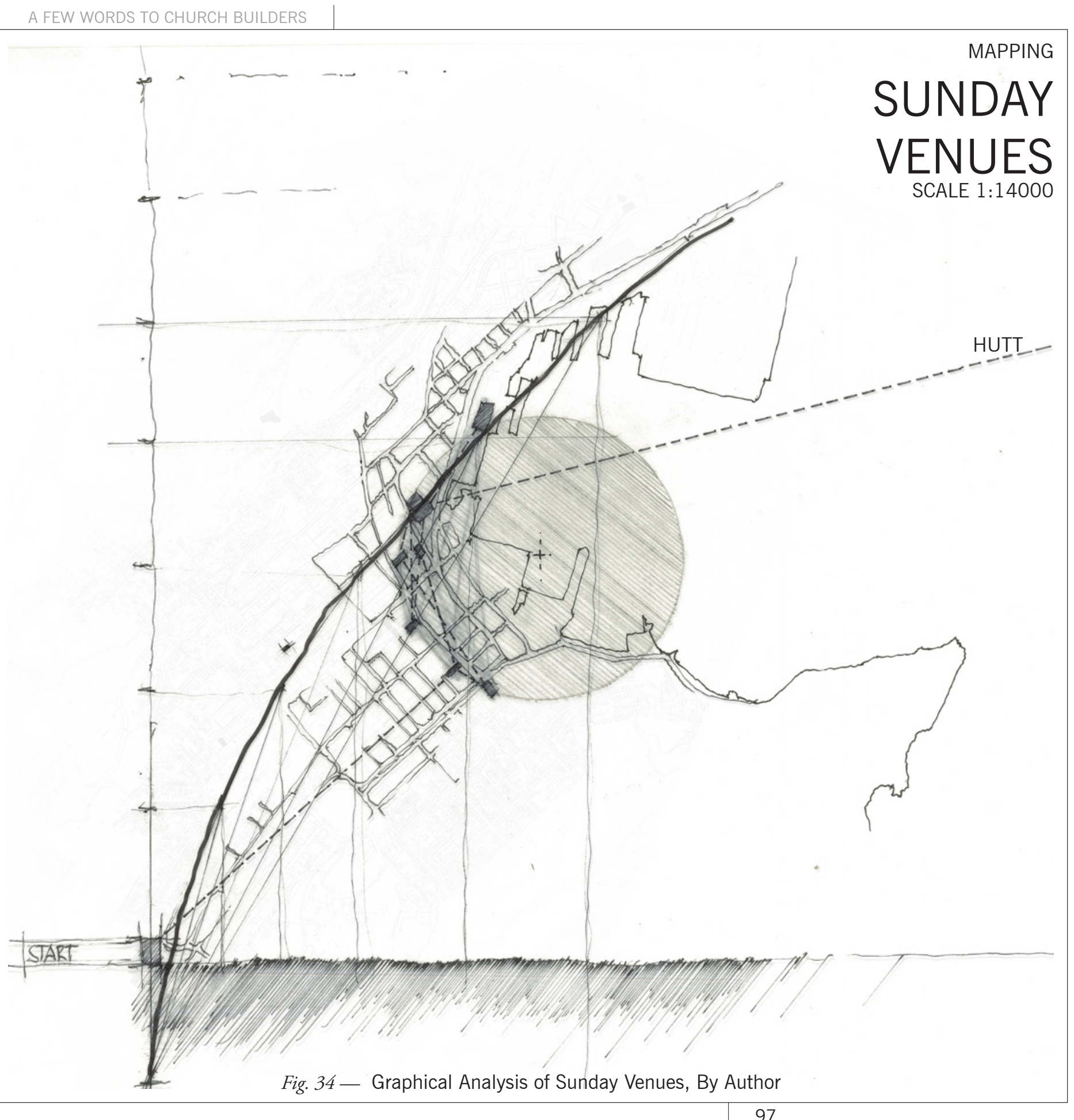

Downtown and waterfront areas are effected by CHURCH spill out and include restaurants, cafes and green areas. Site selection is narrowed to this area.

Fig. 37 identifies St Gerard, its inclusion within the cluster, and its site of prominence questions the role of site within the architectural inquiry specific to ARISE. This site informing an architectural insertion of ARISE into St Gerard in the chapter 'assault' appears disconnected but directly informs TSB Arena site selection.

within a circula clockise refere with the TSB top.

Fig. 35 identifies mid week venues used for smaller group events including youth, young adults, leaders etc. Venues display an extensive scatter beyond the central city.

Fig. 36 identifies the area in which Sunday worship has surrounded for the majority of ARISE CHURCH's life. 

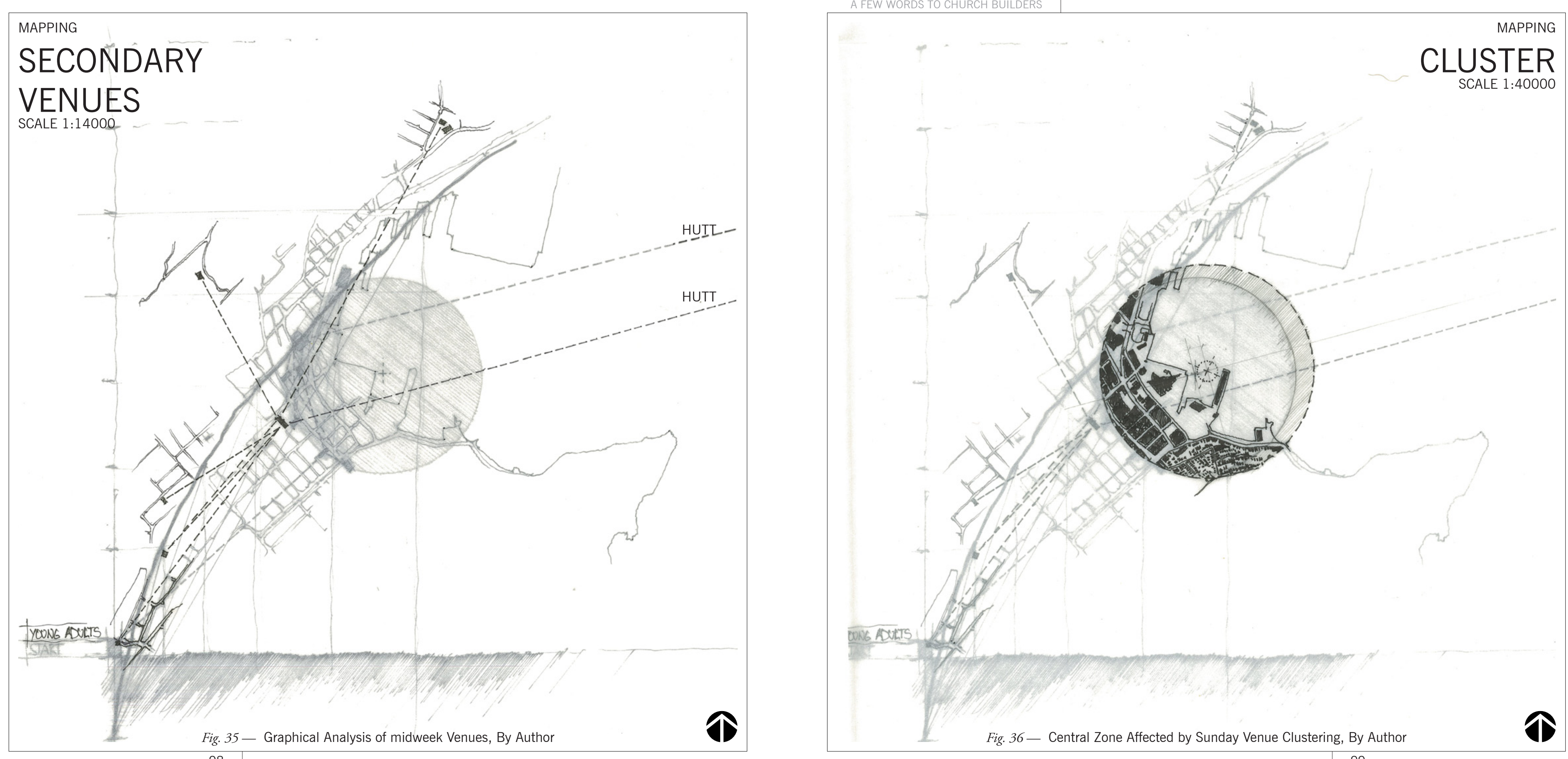


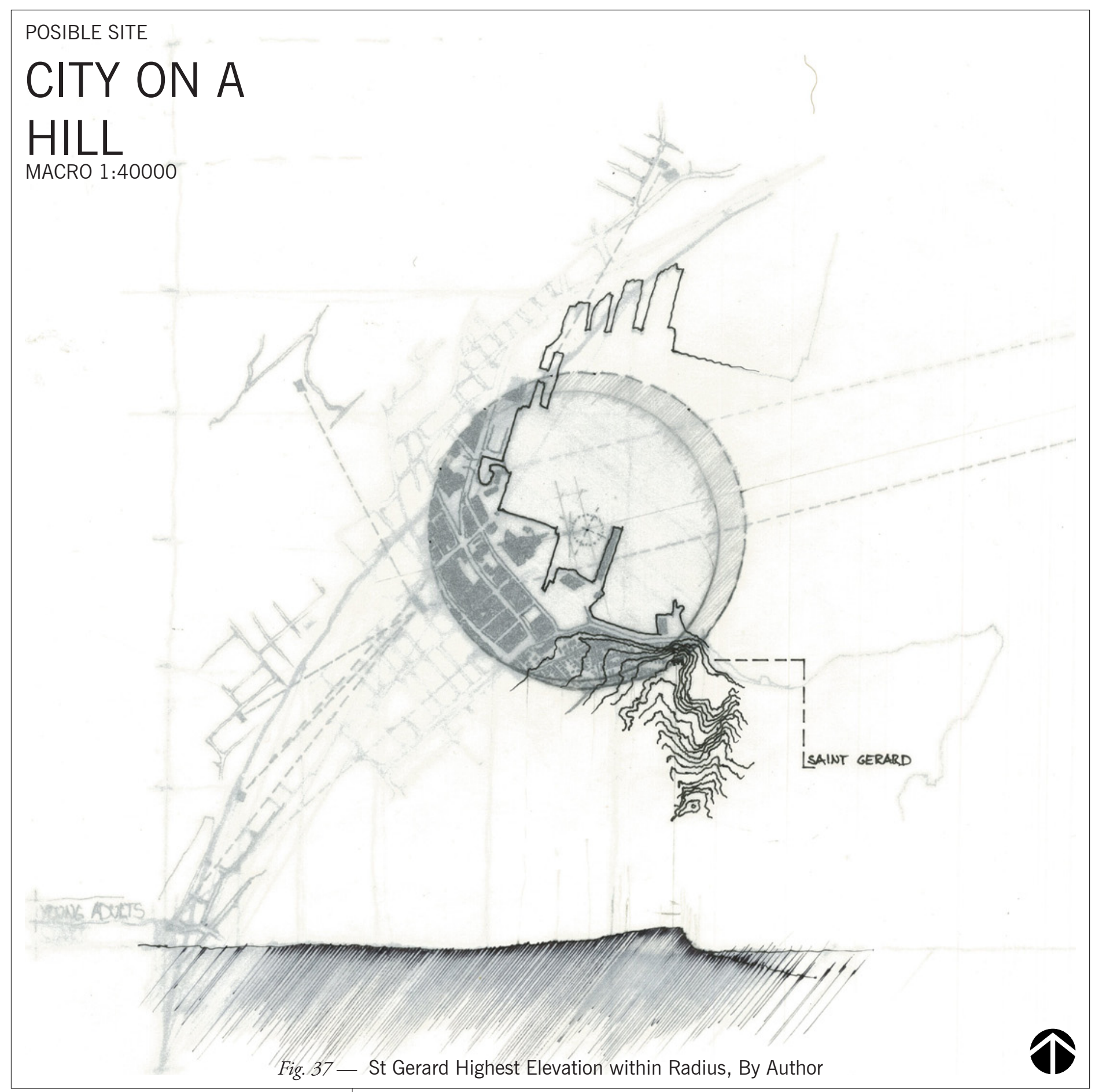

POSIBLE SITE

CITY ON A

HILL

CONCLUSION

Mapping analysis explored macro

characteristics of ARISE. St, Gerard, a

site of prominence raises the notion

of stake, a traditional element specific

to the Church typology. What is ARISE

CHURCH's involvement with the spire

or a site of prominence. The next

three chapters, 'Stake, 'Arise Spire' and

'Assault' seek to answer these questions.

As a result they will inform site and

As a result they will inform site and

final design inquiry.
infue of the 


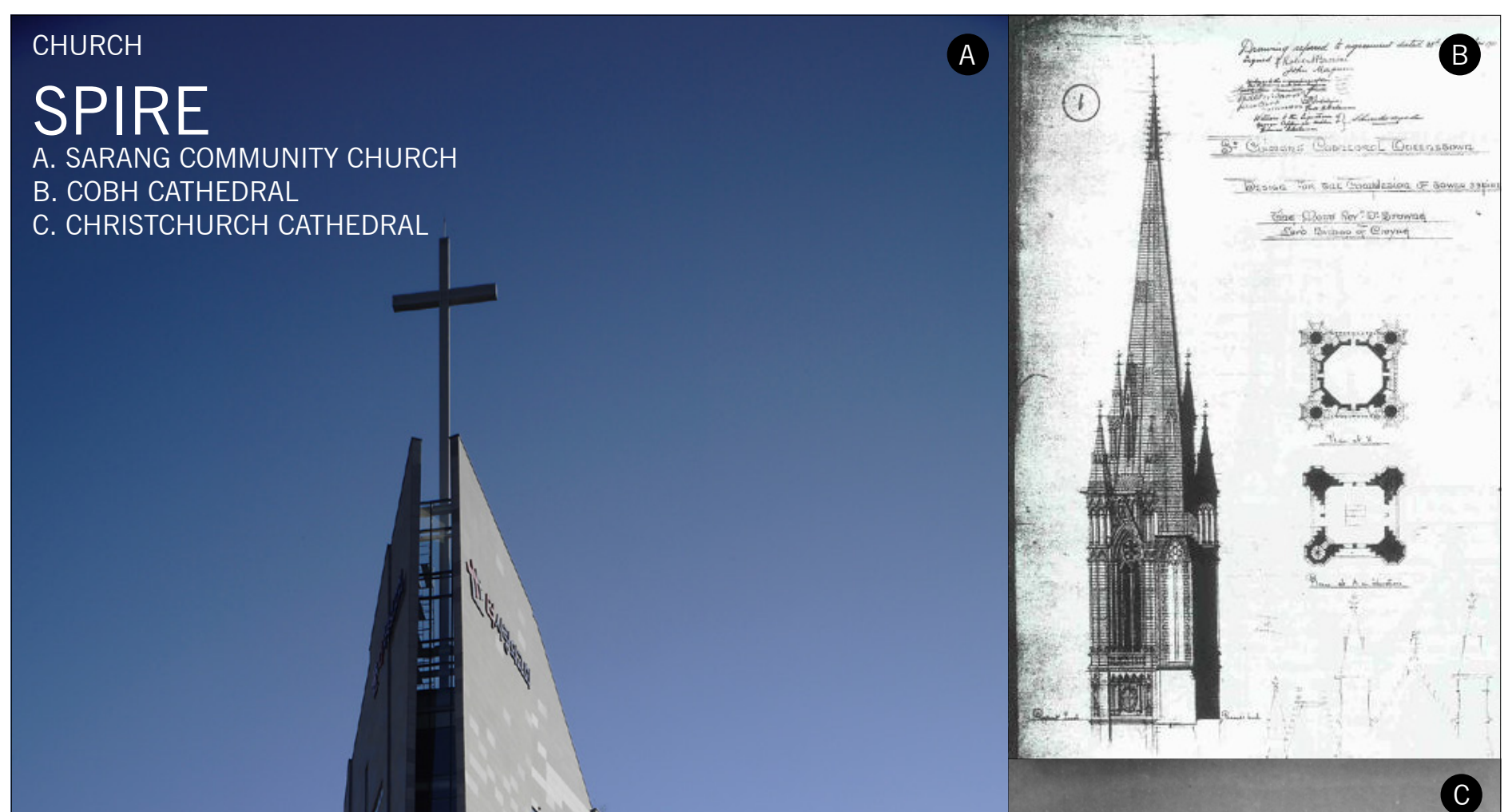

STAKE

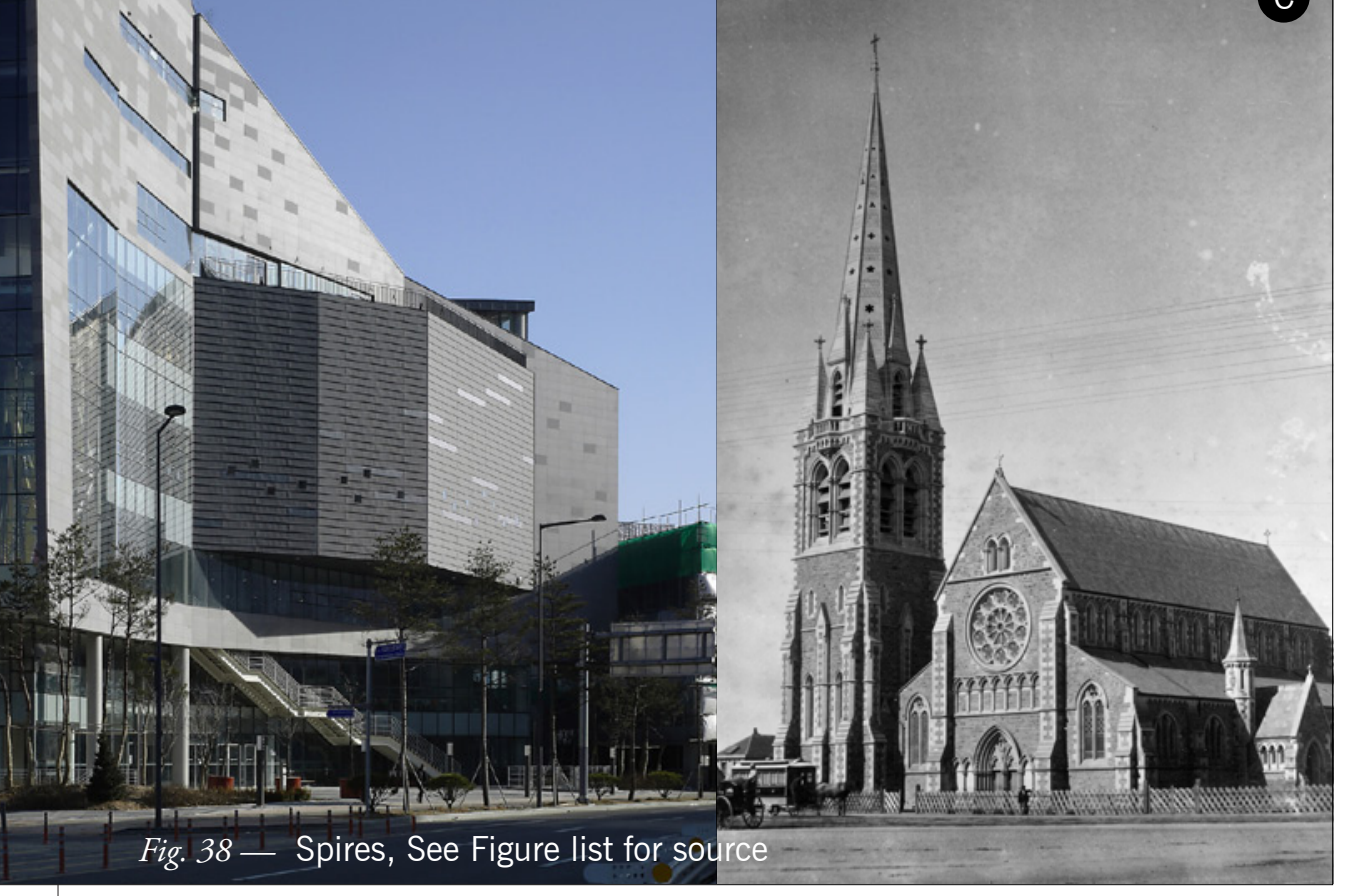

102 
A Spire, a strong vertical element, 'Symbolically, spires are religious and often accompanies a religious political informers, ${ }^{2}$ proclaiming building. Spires can metaphorically martial power giving the impression state ownership, way point, proclaim of strength. The outlined conotations martial power and or reference the of the spire contradicts ARISE CHURCH's transcendent nature of God. This social position within the Wellington section explores the applicability of context. The spire is an architectural spires to an ARISE CHURCH, architectural element that is specific to site, having proposition.

no effect of the presence of God in and about the Church.

Fig. 40 highlights secular structures as the dominant vertical within most cities. Skylines are no longer dominated by the spire as it has been surpassed in verticality by the sky scraper. New York's Woolworth Building was dubbed the cathedral of commerce." This perspective gives context to the question, whether the Pentecostal CHURCH should be represented by a traditional spire.

Fig. 39 includes Church structures, with spires.

The architectural manipulation of spire can determine the way it is perceived. The next design exercise, 'arise spire,' detaches the spire from the context of a Church building and tests its meaning.

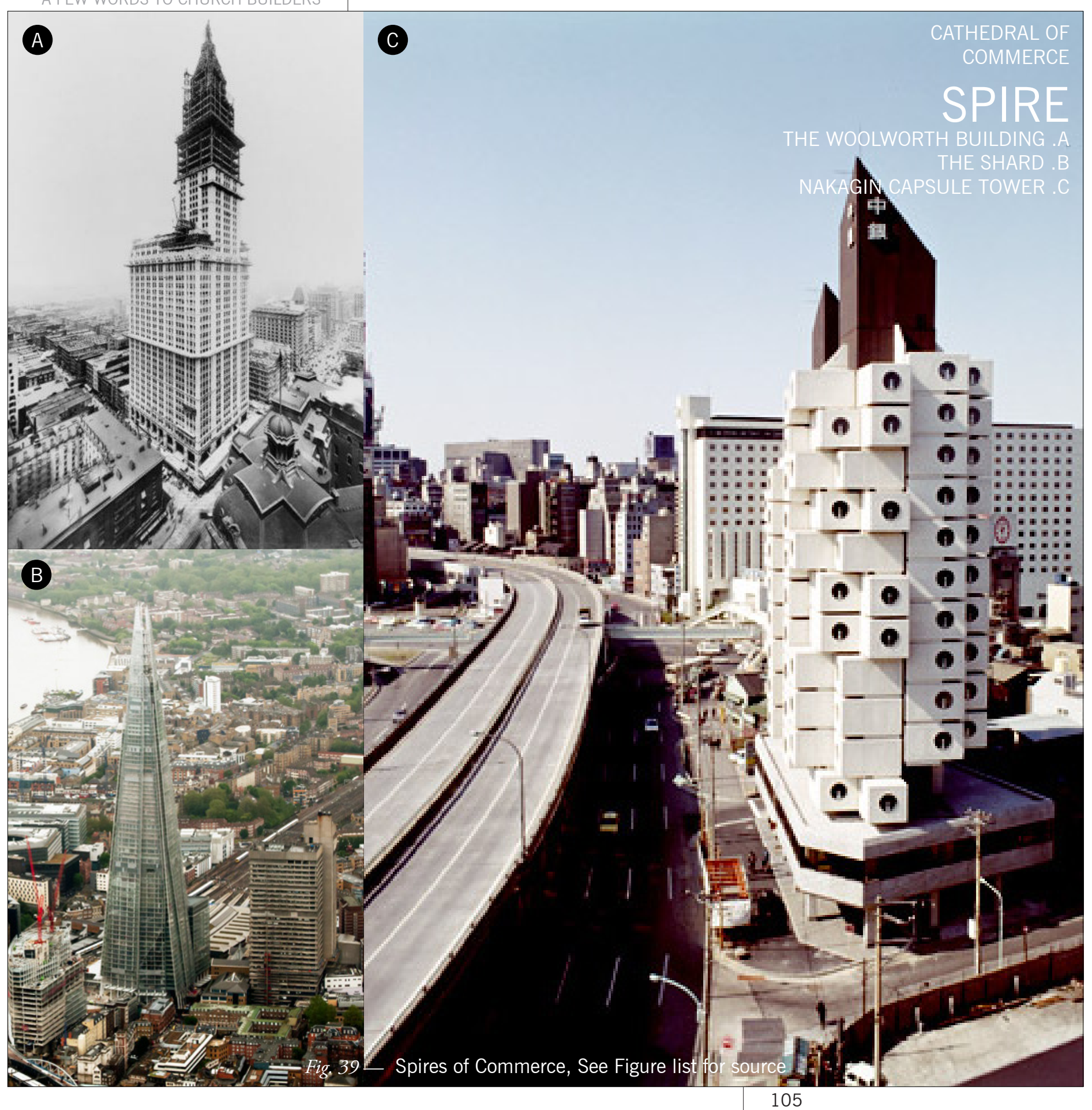




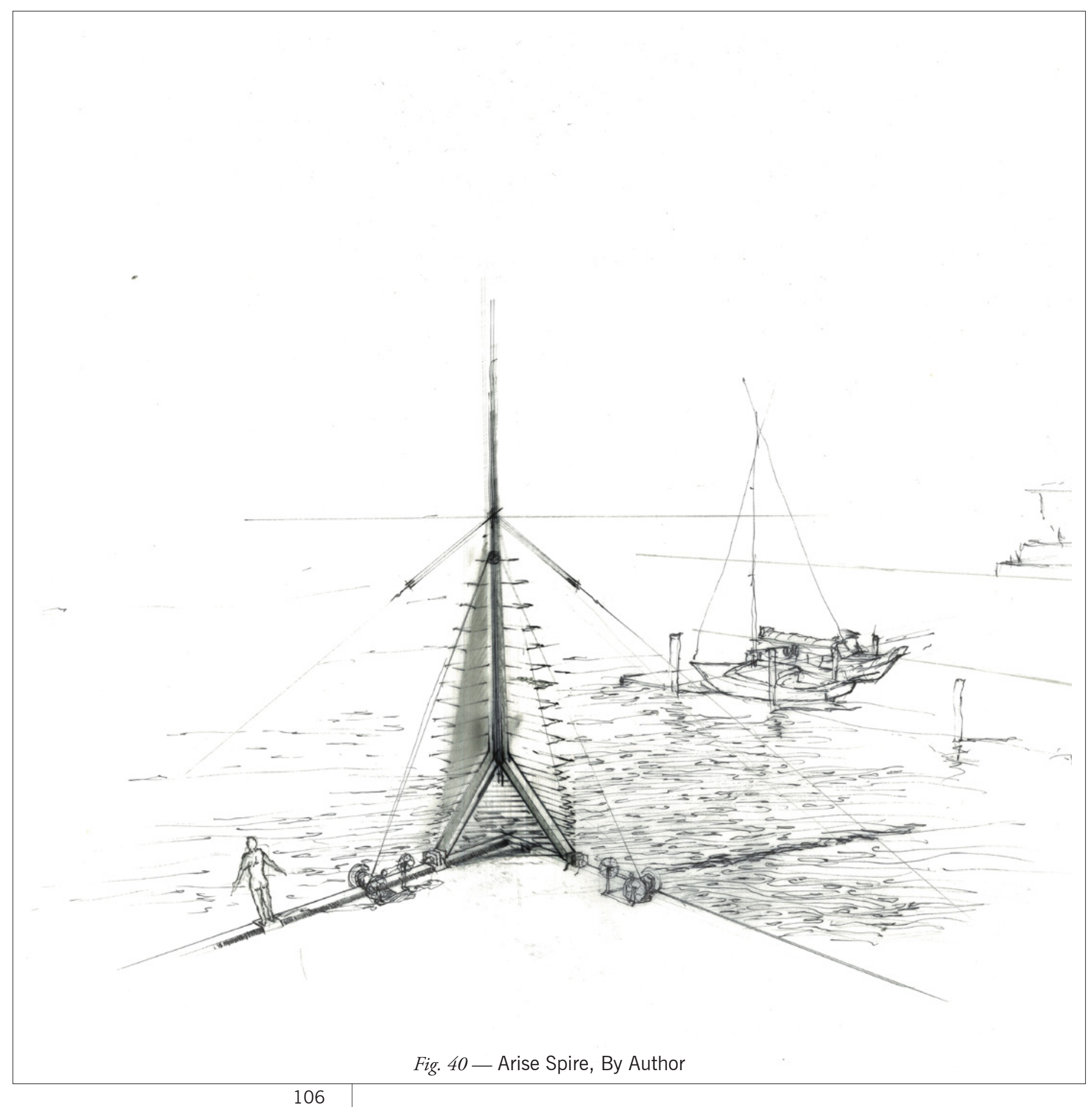

ARISE SPIRE 
A spire is a proclamation of territory, Fig. 43 illustrates a cross built from the a monument to an idea and takes spire and its structural supports. This spiritual ownership and proclaims it is visible from the public thoroughfare. in the physical. This exercise engages The referral to symbolic iconography the spire with the secular. It takes the brings notions of the sacred within the location of spire away from the original secular, attempting an overlap. building.

Fig. 40 the spire design situated on The design outcome manifests a the contempory liturgy of which the waterfront. The design intends the contemporary liturgy of ARISE an interaction with the symbolic CHURCH invites non-Christians to

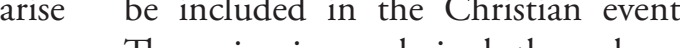
$\begin{array}{ll}\text { the spire. } & \text { Thire is secularised through an } \\ \text { inclusion of the secular with the sacred }\end{array}$

Fig. 41 it is intended that the spire is used as a diving board. The side

elevation suggests movement. The The exercise triggered a needed focus structure is able to be winched down on societal contexts to further consider into the water and is controlled by the in the design process.

people using. This symbolises a secular

ownership about the sacred.

Fig. 42 the spire location geographically marks the epicentre of the rented venue cluster within the city.

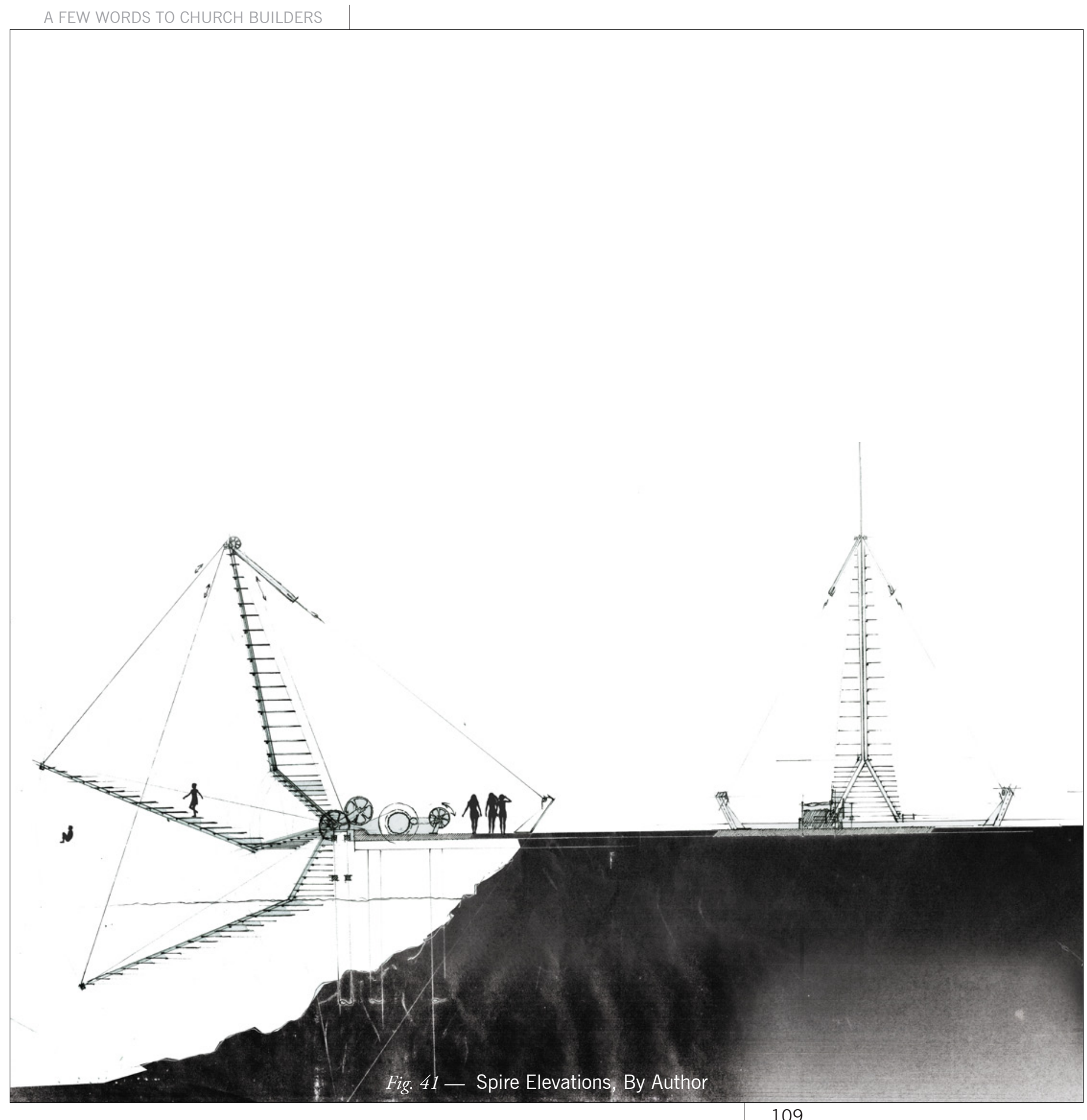



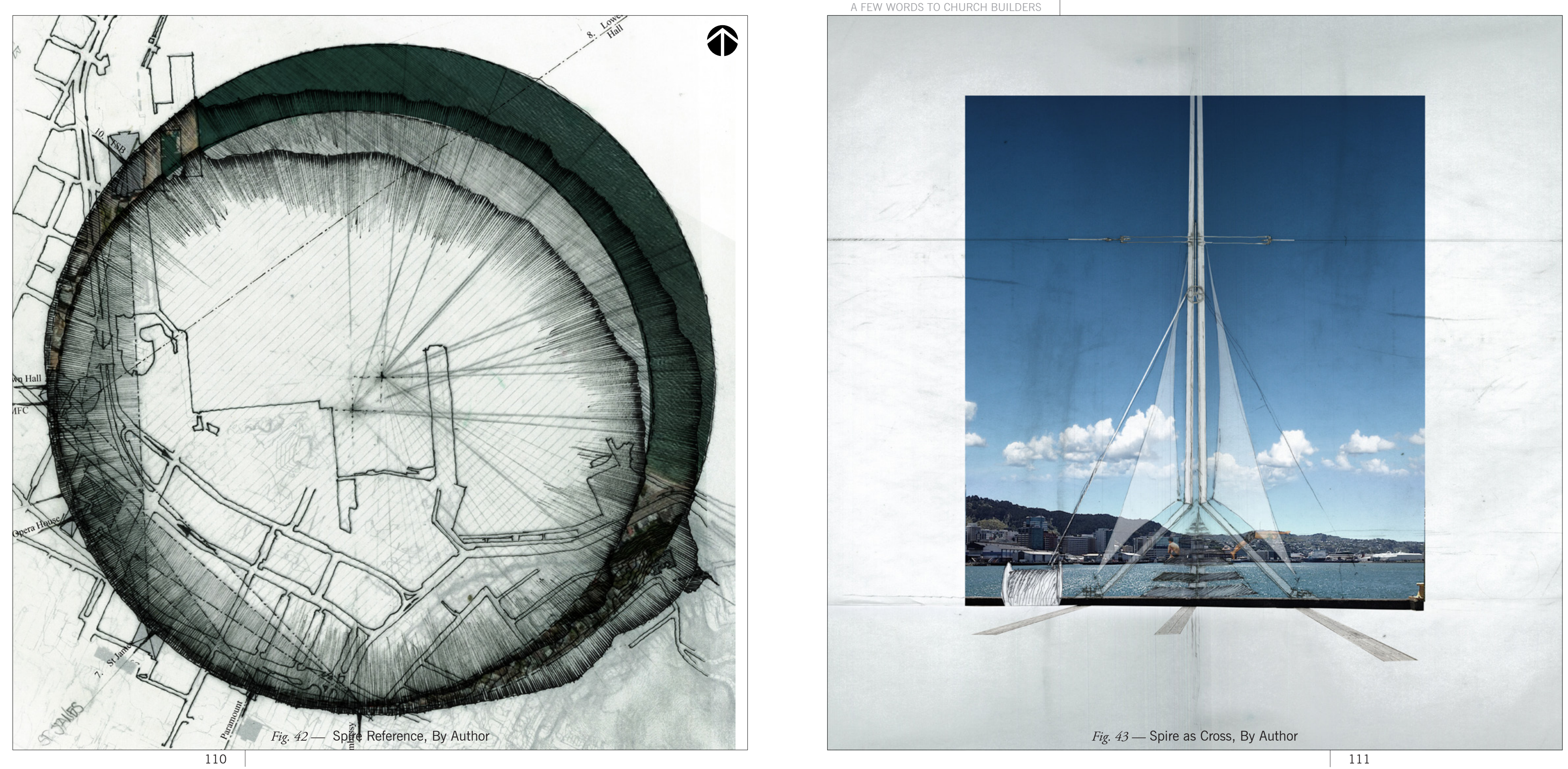


\section{ASSAULT}

Fig. 44 - St Gerard, By Author 
This exercise is informed by 'Site Macro' and 'spire,' inserts ARISE into St Gerard to question both site and the architectural language to represent ARISE СHURCH. The site questions prominence, posture and social engagement while the design component identifies the design trajectory within a wider architectura spectrum. This is achieved through the insertion of an architecture responding to a contemporary liturgy ind to a contemporary liturgy into structure liturgy

Fig. 44 shows the buildings position of St Gerard within the landscape, a Catholic monastery and a Wellington landmark. Its position within the elevated topography gives it a position of prominence. The buildin however follows a cannon of Catholic architectural criteia, the visul weich architectural citen, the visnal weight of the ranscendent structure sits heavily upon the site providing no permeability to the public.
Fig. 45, design inserted into St Gerard. The malleable language seen in the sketch, softens and contradicts the solid nature of the existing wall. The envelope now the existing wall. The per releases the contained programme through the undercut at ground level, contradicting the containable nature of the existing structure. The visual language of this intervention appears destructive, round maing it vulu

Form highlights reoccurring motifs when compared with earlier design investigations, these include the 'undercut' and a 'permeable envelope.' This design intervention highlights a contrast between the architectural manifestations of ARISE a Pentecostal liturgy and the liturgy and the existing traditional
Catholic architecture. 


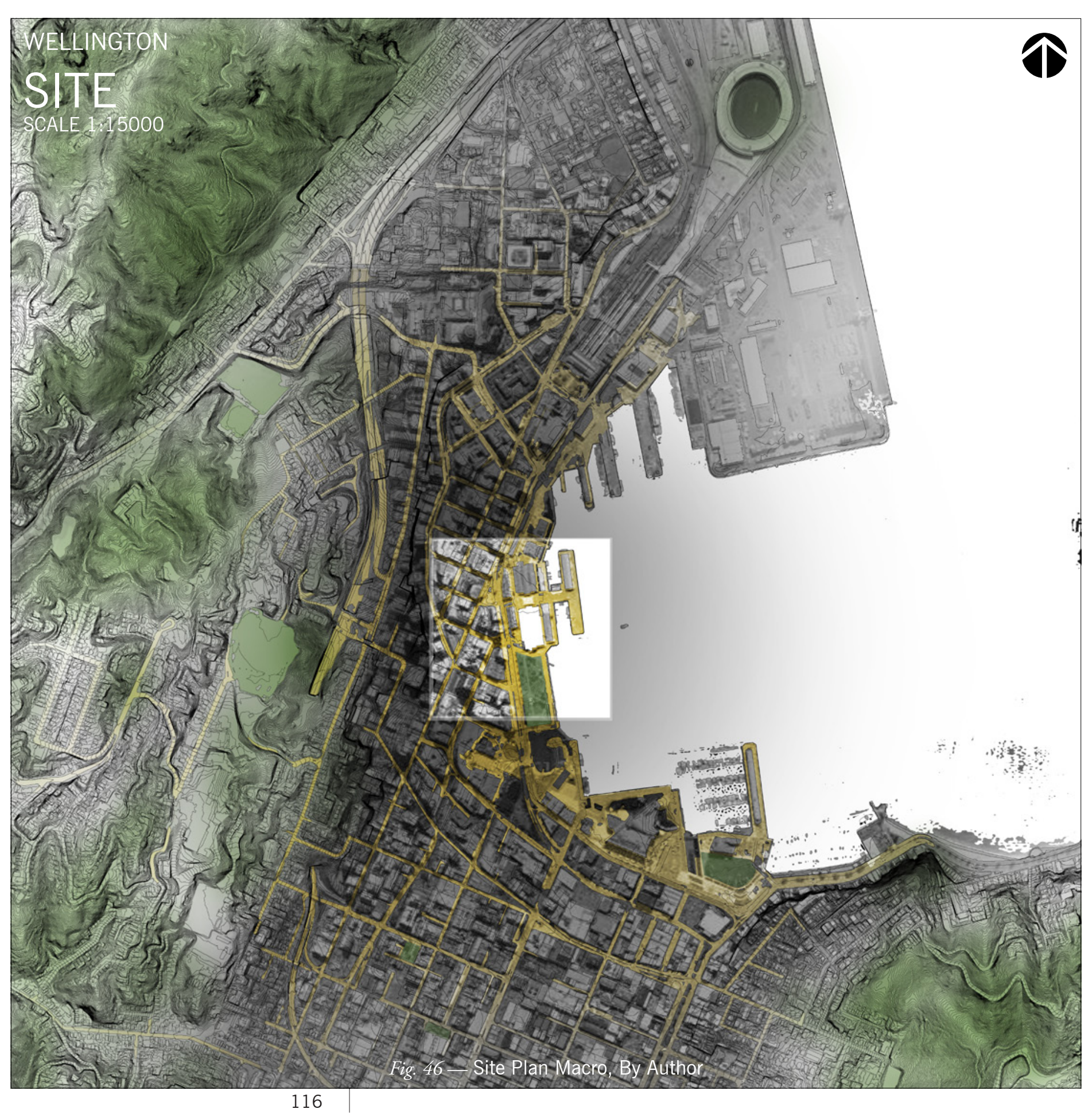

SITE

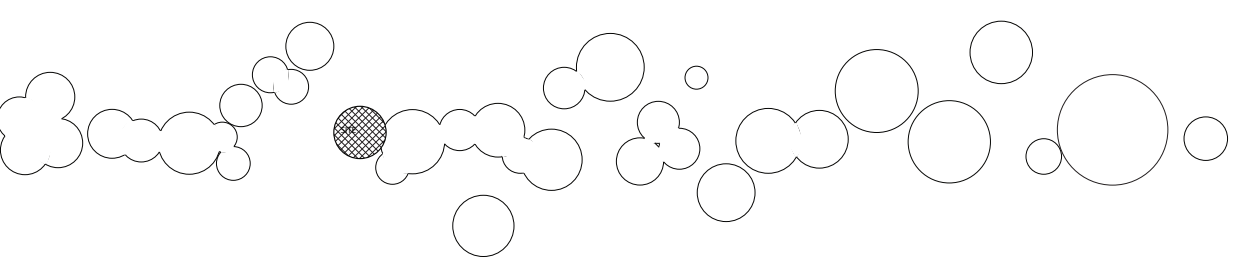




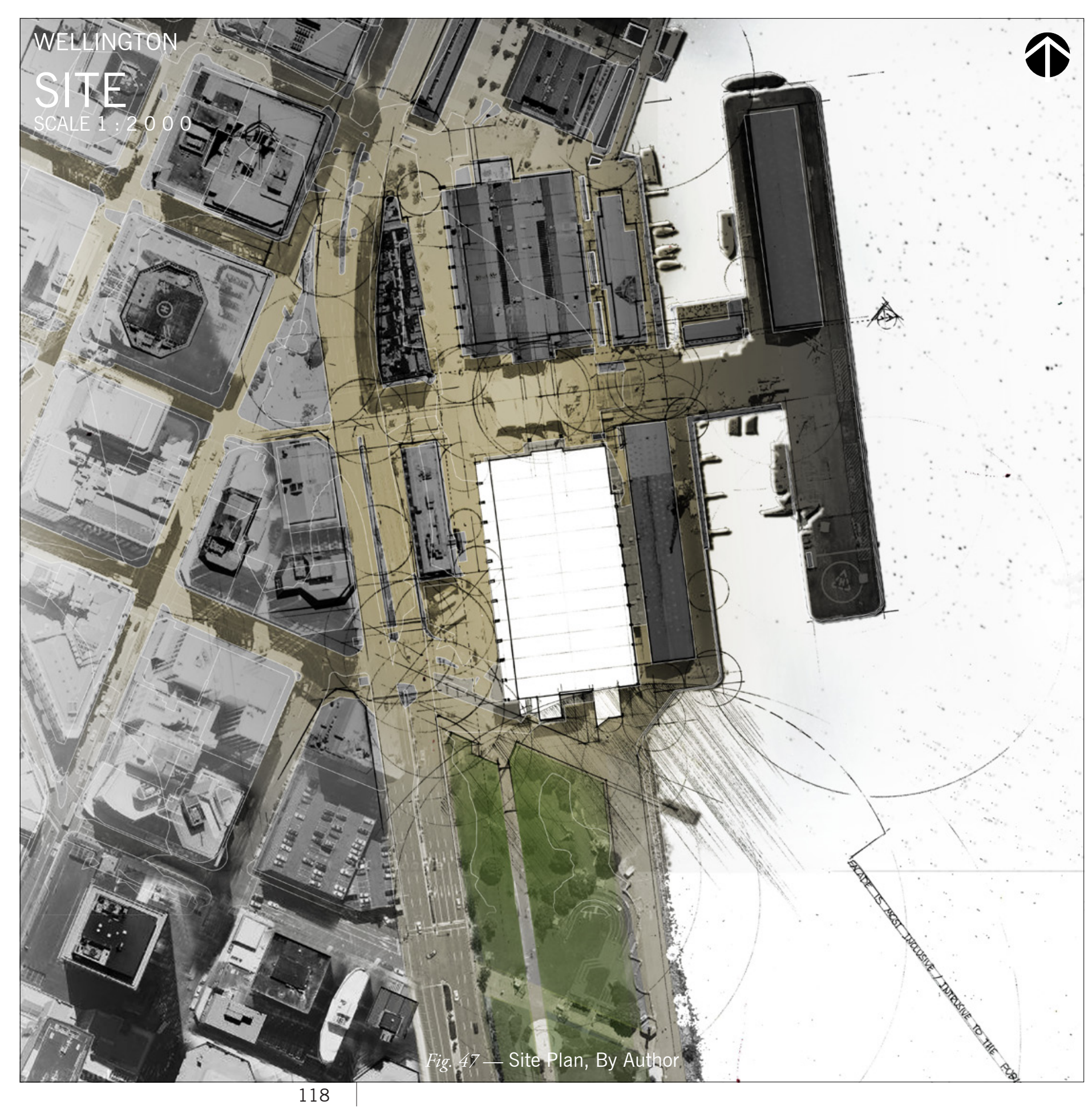

\section{INTRODUCTION}

The TSB Arena is a large, multipurpose venue situated in the Queens Wharf precinct on Wellington's waterfront and home to trade shows, indoor sporting events and concerts. The building will form basic constraints for the architectural insertion of ARISE CHURCH.

The make up of the surrounding building types and their functions assist in informing the secular programs with which to test the overall proposition of engaging the secular with the sacred.

The site will give opportunities to test an architecture that acts in consistency with the contents of the ARISE character. SITE

The TSB Arena sits on the waterfront and within a downtown metropolitan area, this location subjects development on the site to a unique set of urban influences. Kent A Robertson's classifies large venues like the TSB as a 'special activity generator,' while its site classifies it as a 'water front development.'

Robertson outlines key considerations informing urban integration. The TSB Arena is a large facility capable of drawing large numbers of visitors,

1. Robertson, Kent A. 1995. pg 433 . Robertson, Kent A. 1995. pg 433 many from outside the metropolitan of people also creates a spillover effect, feeding the surrounding urban environment of restaurants, shops and tourist attractions. But when not in use (which is most of the time) the TSB Arena creates 'dead space,' at a high cost to public space.

The TSB Arena fits Robertson's criteria of 'water-related,'3 rather than dependent or enhanced. He claims area, into the downtown. ${ }^{2}$ The drawing the sight sound, and feel of water 

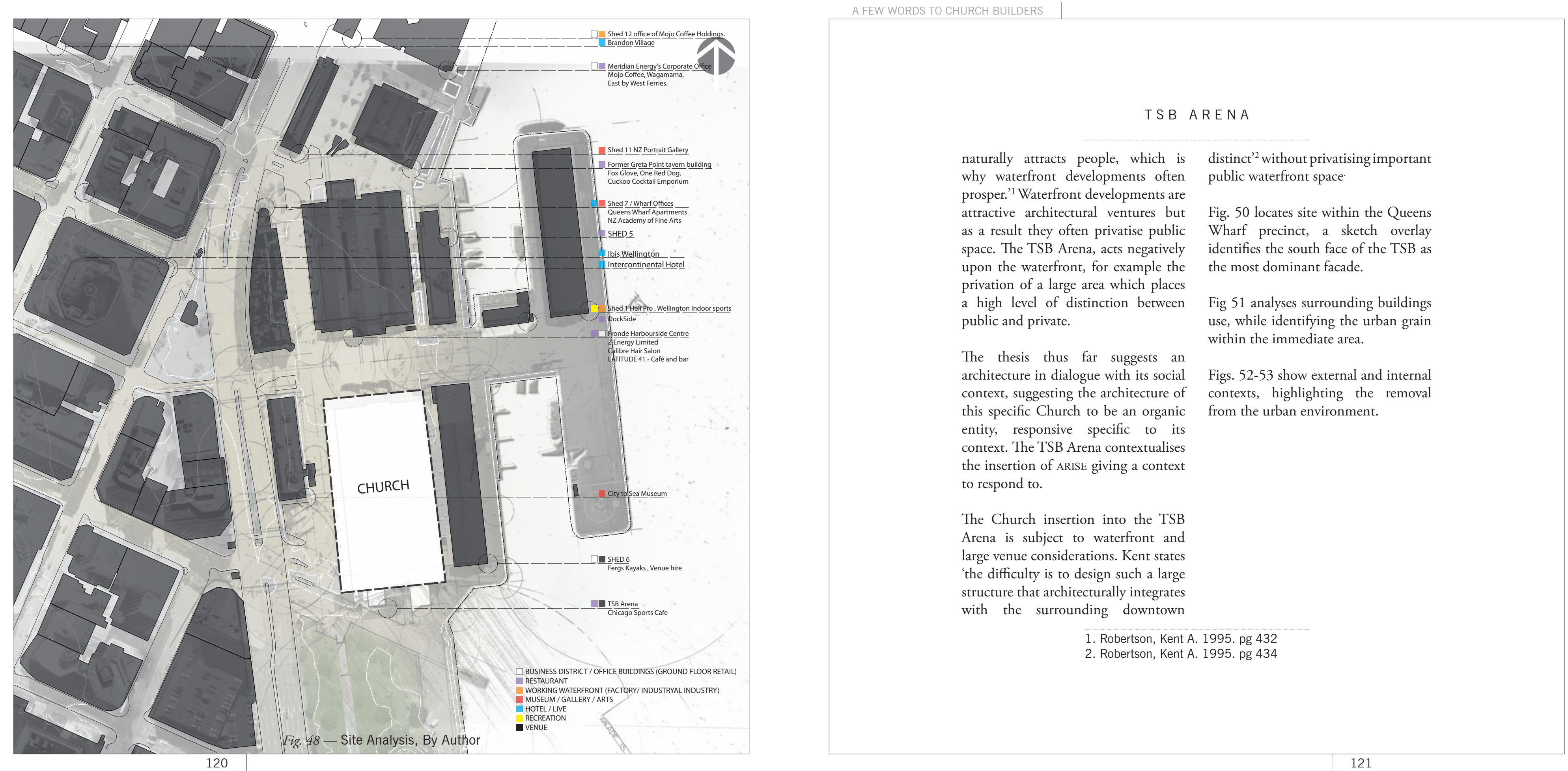


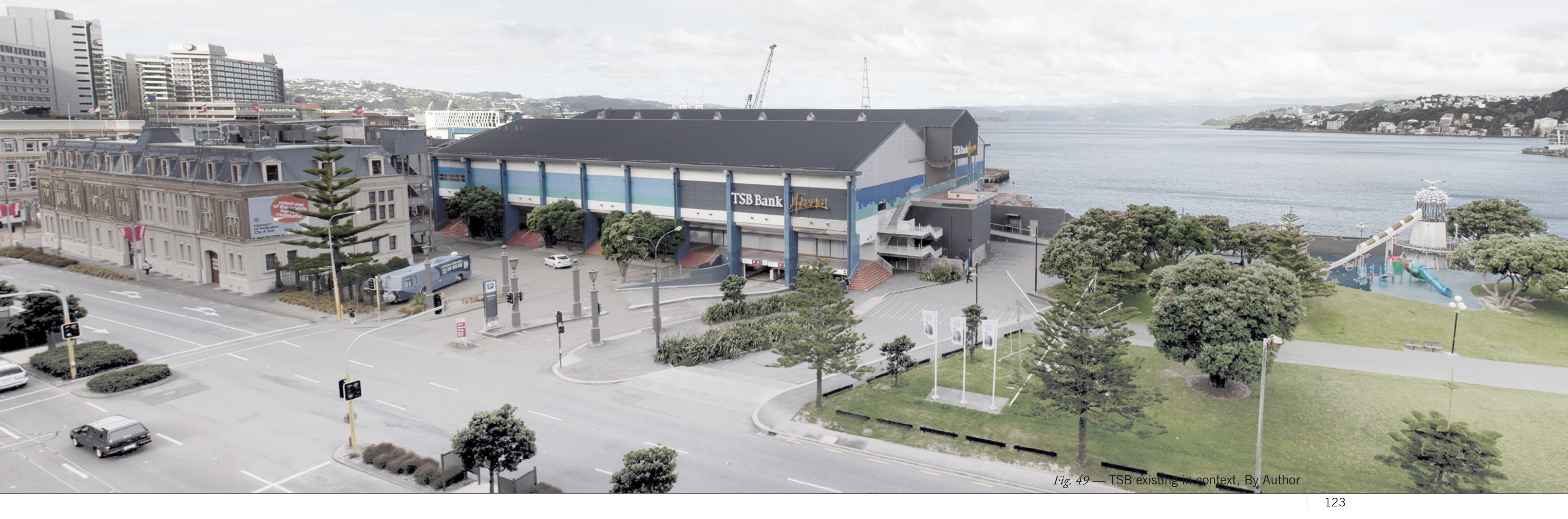




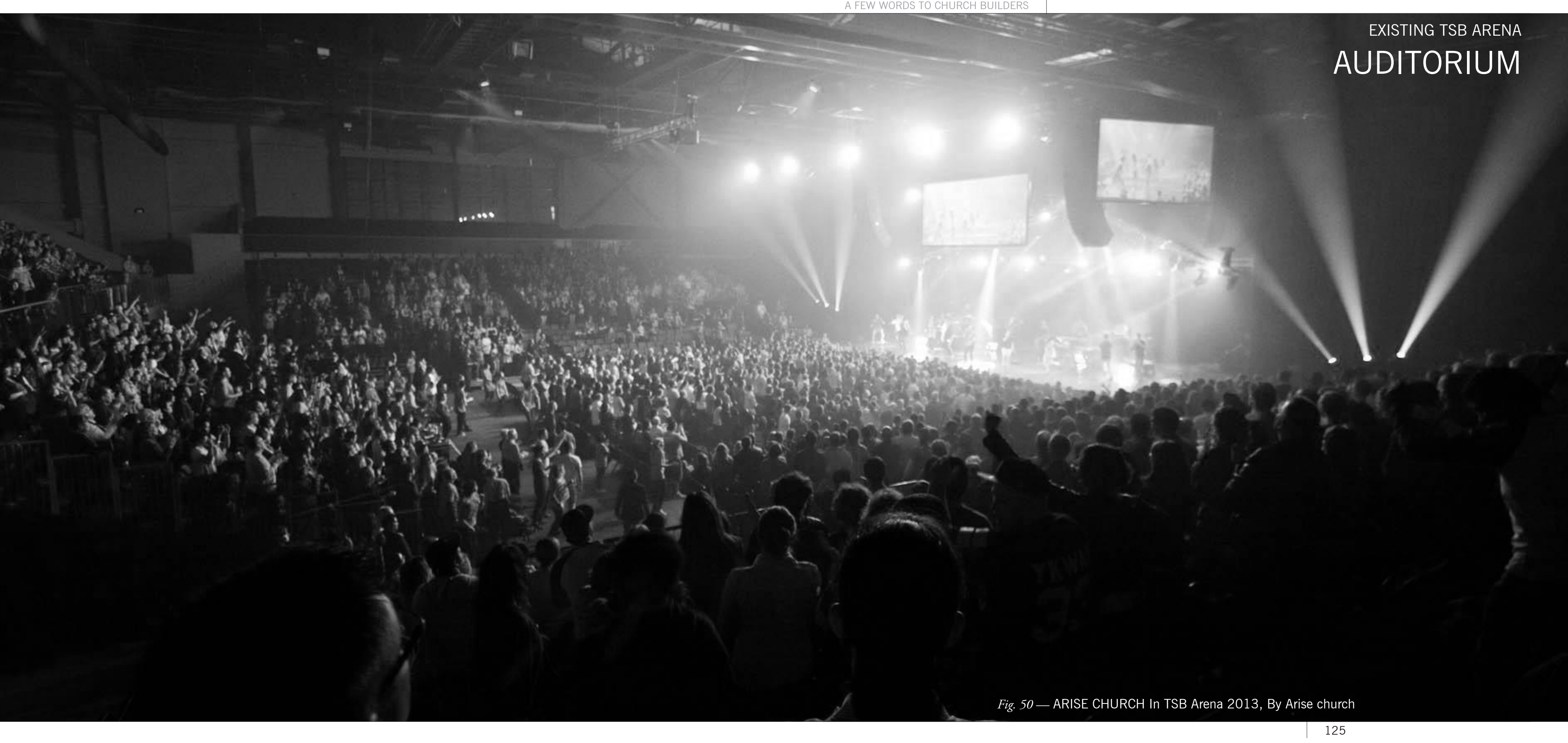




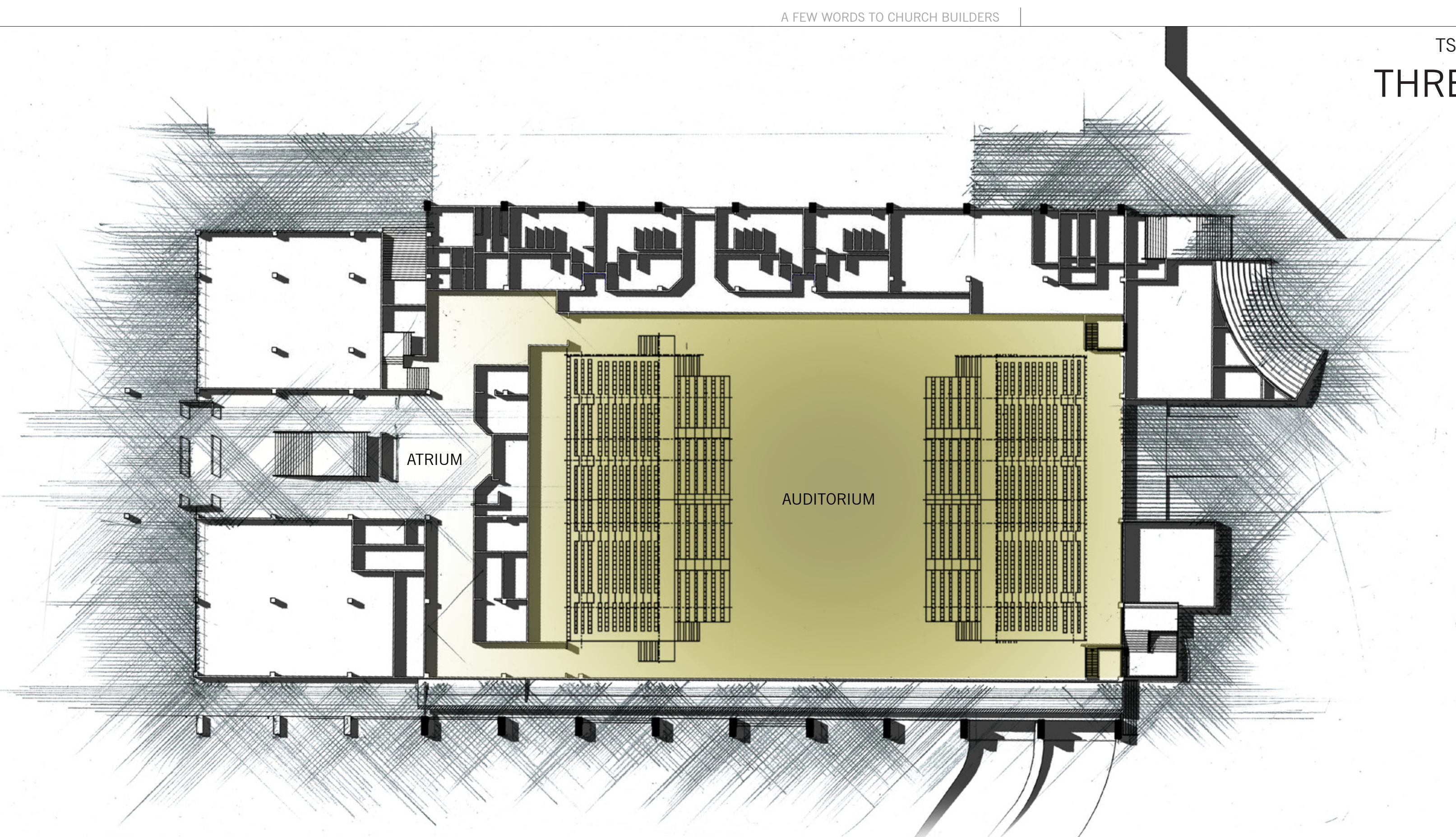




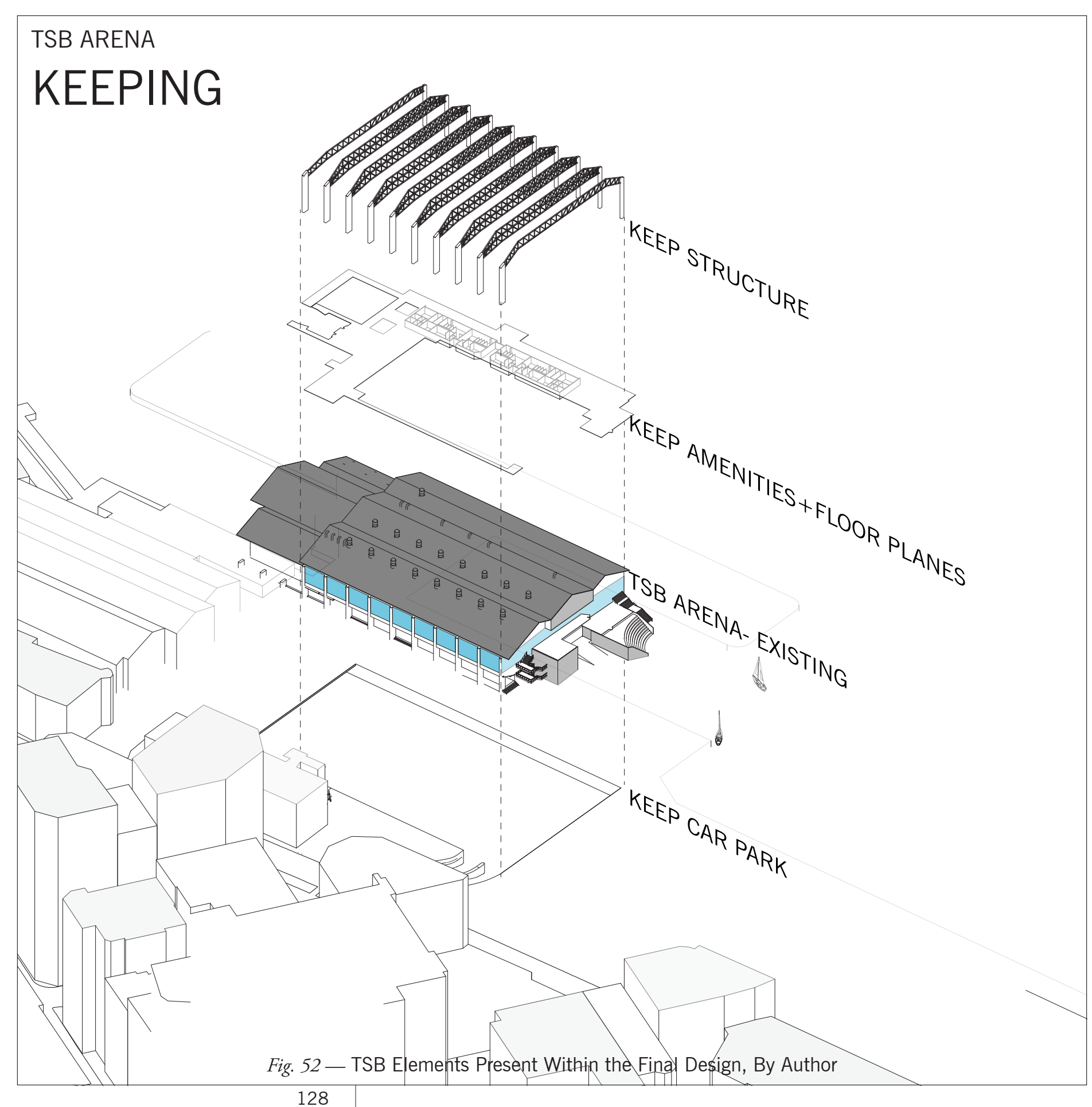

Fig. 54 is a ground floor plan of the and release, will clearly require an existing TSB Arena. The image helps architectural operation on the existing to establish the areas of threshold structure.

(hatching). At first view, the plan

and spatial arrangement allow no Fig. 55 is an exploded axonometric interaction between the internal of existing TSB Arena, identifying and external environment other elements that will need to be considered than through the single entrance on in the final design; structure, amenities the north side. The criterium for a and car park facilities.

Pentecostal architecture described in

the previous sections, such as efflux

CONCLUSION

The TSB Arena site will contextualise design iterations for the remainder of

the thesis. 'Past venues' and the 'St

Gerard' insertion contribute to the

selection of the TSB Arena as site.

This allocated site embodies aspects

that will challenge the insertion of

ARISE in regards to a secular and sacred threshold. 
$\mathrm{CHURCH}$ REFLECTION 
This design investigation explores

an architecture that activates

when inhabited - the maquette is

a contextualised (response to site)

reaction to the 'envelope' study.

Fig. 56 shows maquette at full

expansion. An overlaid sketch hints

toward habitation while contrasting

materials discuss while contrasting

materials discuss threshold. The

fabric envelope experiences changing

material properties, seen in the

envelope study- permeability. This

enables a changing dialogue between

secular and sacred.

Fig. 57 contextualised design themes.

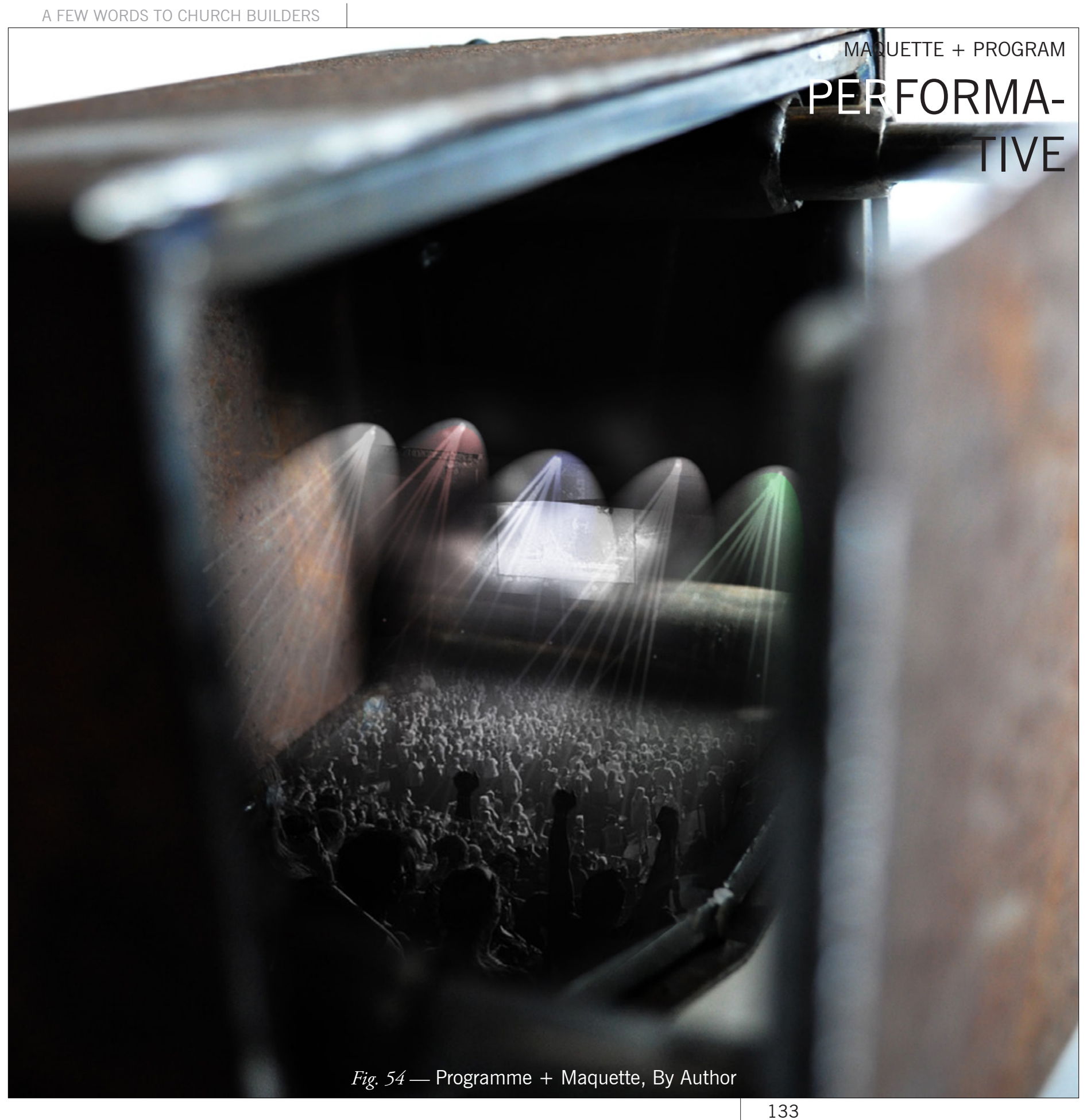




\section{$\mathrm{NON}-\mathrm{CHURCH}$}




\section{BLURRING BOUNDARIES}

In present-day floating society it is absolutely essential to remove the boundaries based on simplifying functions and to establish a relationship of superimposition of the spaces. A room is required which can add sites of change. ' Toyo Ito'

Toyo Ito's book 'Blurring Architecture' outlines strategies to blur boundaries:

one of which is the transforming of program within a space. This strategy informs 'design iteration one.'

Fig. 60 overlay sports facility and ARISE weekly programmes.

Fig. 61 contextualises the combined program into site.

Toyo Ito states; 'blurring architecture The exercise questions a dual purpose must have a floating character Church. The 1950s Church Building permitting temporal changes. This Society of London stated; 'A building means that a room construction must can either be a church or a hall, either allow programme changes. ${ }^{2}$ This religious or secular.'

investigation adopts Ito's strategy,

combining a sports facility with

the Church to blur the boundaies

perceived between the secular and

sacred.

Fig. 58 a perceived weekly timetable of ARISE CHURCH

This exercise applies a secular and ar and che of people unf iliar wih chung of people unfamiliar with $\mathrm{CHURCH}$ Boflores Bonhoeffer's desire to see the church applicable to the secular.

Fig. 59 a perceived weekly timetable of

a sports facility.

$$
\begin{aligned}
& \text { 1. Ito, Toyo. 1999. pg } 59 \\
& \text { 2. Ito, Toyo. 1999. pg } 58 \\
& \text { 3. Incorporated Church Building Society. 1957. pg } 9 \\
& \text { 4. Torgerson, Mark. 2007. pg } 17
\end{aligned}
$$

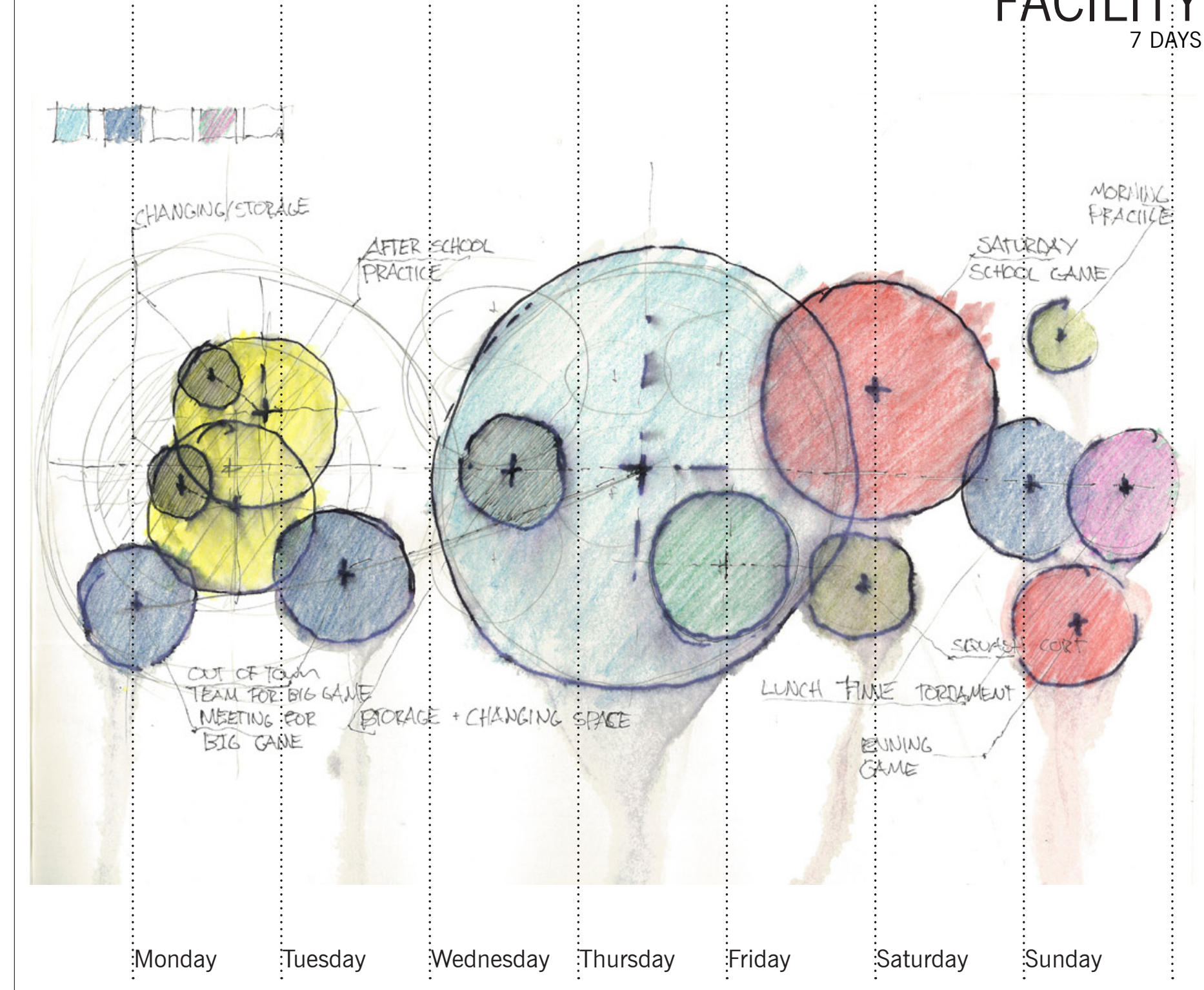



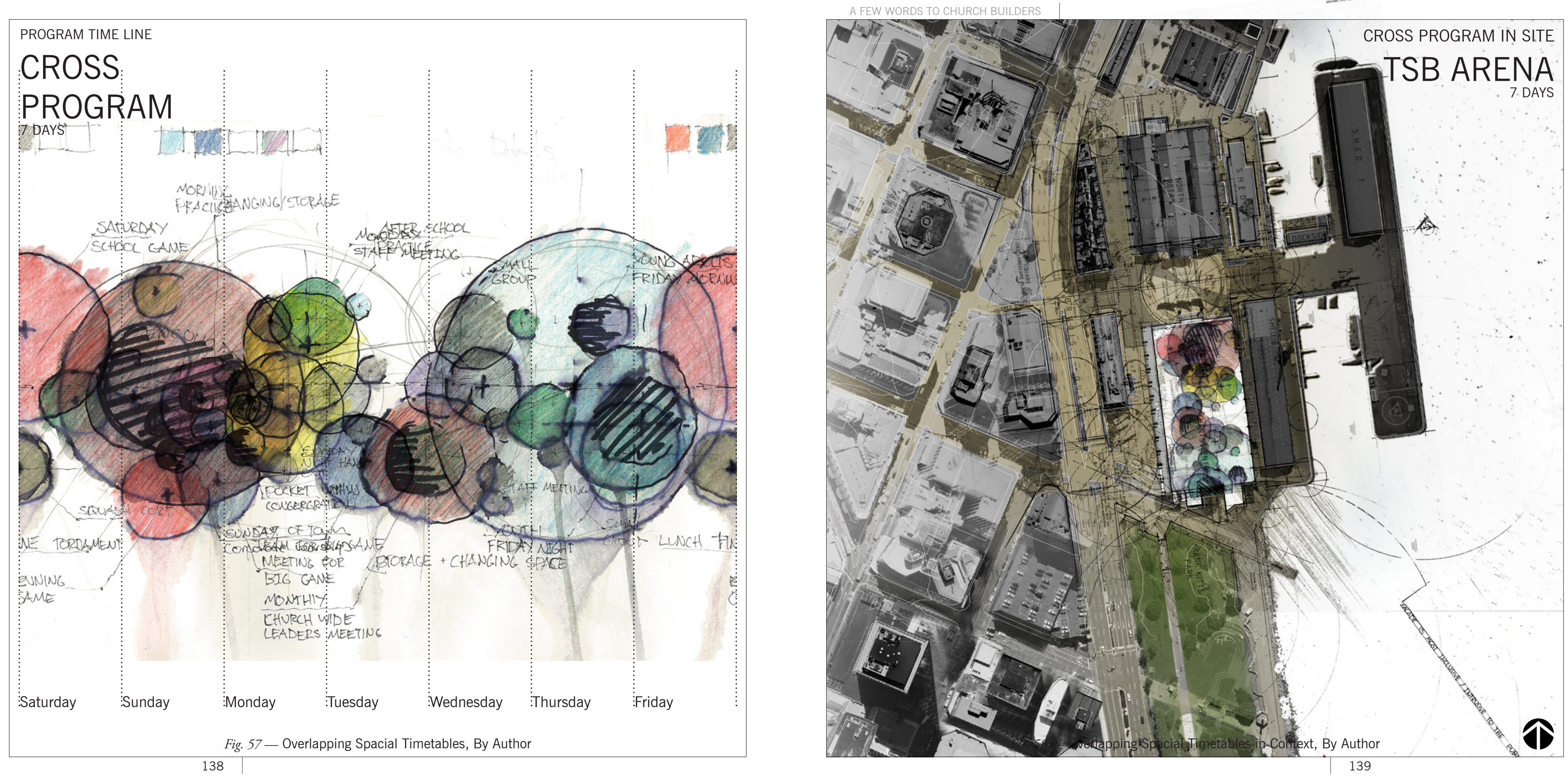
God is where man is, wherever he is However in most recent history, on Earth or in outer space. The place, Christian Church buildings have therefore, may turn out to be less secularised the sacred, adapting to important than the presence of the person."

Sovik details an architecture 'devoid of cultic images or furnishings, ${ }^{2}$ an architecture that breaks the 'improper association with worship as function of place, images or things. ${ }^{3} \mathrm{He}$ also affirms an architecture concerned with social contexts straying from religious or cultic notions. This move is reflected in the contents of ARISE CHURCH.

Most traditional Churches are today reminiscent of the 1600 year old Constantine ideals. Sovik claims 'This change was catastrophic for the CHURCH' 4 The influential factor the cinisu restriction of God's presence to the building, separating g the sacred and secular

The Pentecostal снurch follows the sentiment that Christianity is about community, shifting away from an internal to an external focus. Sovik claims 'Church structures should not be bult un ws they are directed to the bervice of he com arected to the service of the come people around them, The building can become a means for the Christian community to provide as effectively as possible not only for its own needs, but for the needs of the community.' An architectural inclusion of the community within the building beyond Sunday services is developed in the design component of the thesis.

Mega Churches question the rigid distinction drawn between the sacred and the secular. Form devoid of reference to the sacred is often

1. Torgerson Mark, 2007, pg 20

2. Sovik, E. 1973. pg 37

3. Sovik, E. 1973. pg 37

4. Sovik, E. 1973. pg 17

5. Sovik, E. 1973. pg 15

6. Sovik, E. 1973. pg 39
7. Sovik, E. 1973. pg 39 
critiqued as 'failing to inspire awe or to "celebrate the transcendent nature of God."' The book 'From Meetinghouse secular blur, seen in the architecture representing many large Protestant or Pentecostal communities known as mega Churches. Their secular architecture provokes criticism of the sacralisation of Church architecture from religious chuch architecture Church should embody the sacre the sacred and eschew the profane.'2

J Robinson's writing promoted the elimination of a distinction between sacred and secular. 'Scholars in various fields have begun to question the rigid distinction drawn between the sacred and the profane, insisting that in some cultures they have often overlapped or mingled.'

These large Churches are critiqued by an Australian critic Julia Baird
as corporate. She states,' The more

$$
\begin{aligned}
& \text { 1. Loveland Anna et al, 2002, pg } 239 \\
& \text { 2. Loveland Anna et al, 2002, pg } 239 \\
& \text { 3. Loveland Anna et al, 2002, pg } 239 \\
& \text { 4. Baird, Julia. (2006, February 23) pg } 1 \\
& \text { 5. Torgerson Mark, 2007, pg 20 }
\end{aligned}
$$

An architecture attempting to manifest

transcendence is, according to the Non-Church position inappropriate, instead the secular is invited to encounter God. Encounter with God takes place not because men leave their ordinary lives and proceed to a different place where God is but because God enters their world and their lives where they are.'1

Design will overlap the sacred and secular in thresholds with the additional architectural tools of programme, form, envelope and materiality. 


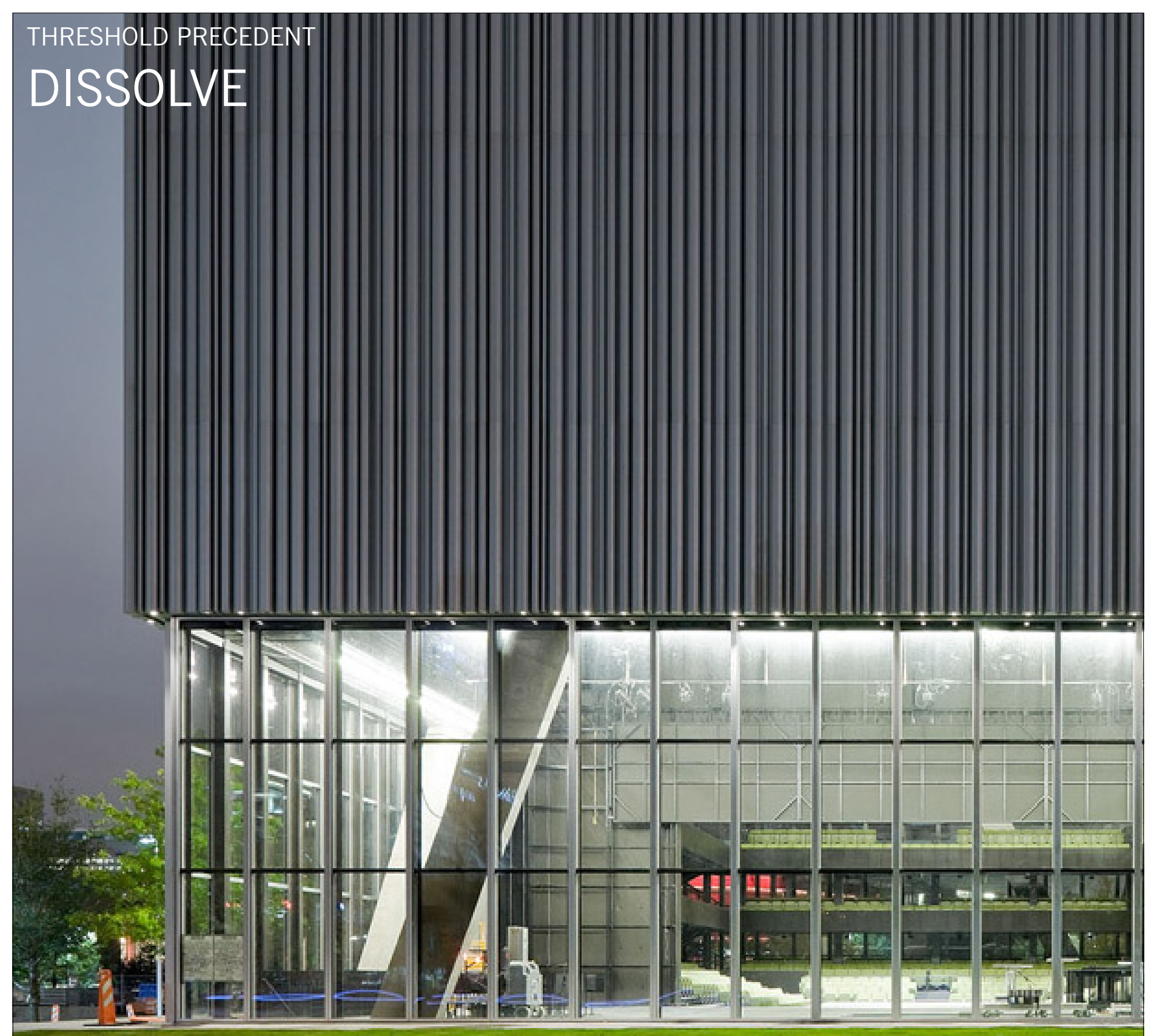

THRESHOLD PRECEDENT 
The thesis has predominantly discussed The Wyly theatre as an example of

the sacred and secular threshold within 'architecture that does stuff rather than an architectural envelope. Wyly Theatre by REX dissolves threshold engaging the external environment (secular) with the internal performance.

Fig. 59 The Wyly Theatre creates a visual connection between internal performance and exterior context.

Fig. 62 a diagrammatic section used by REX to explain the horizontal external, internal threshold, created by placing front and back of house above and below the ground plane. The sides are left free to respond to externa conditions. The theatre has full contro over the concealing and revealing between conditions, showing only what is intended to be seen.

Fig. 61 a series of plans display the Wyly Theatres ability to rapidly change an auditorium layout. Joseph Razmus Prince director of REX describes the

1. Prince-Ramus, Joshua. (Oct 2009). ust representing it.

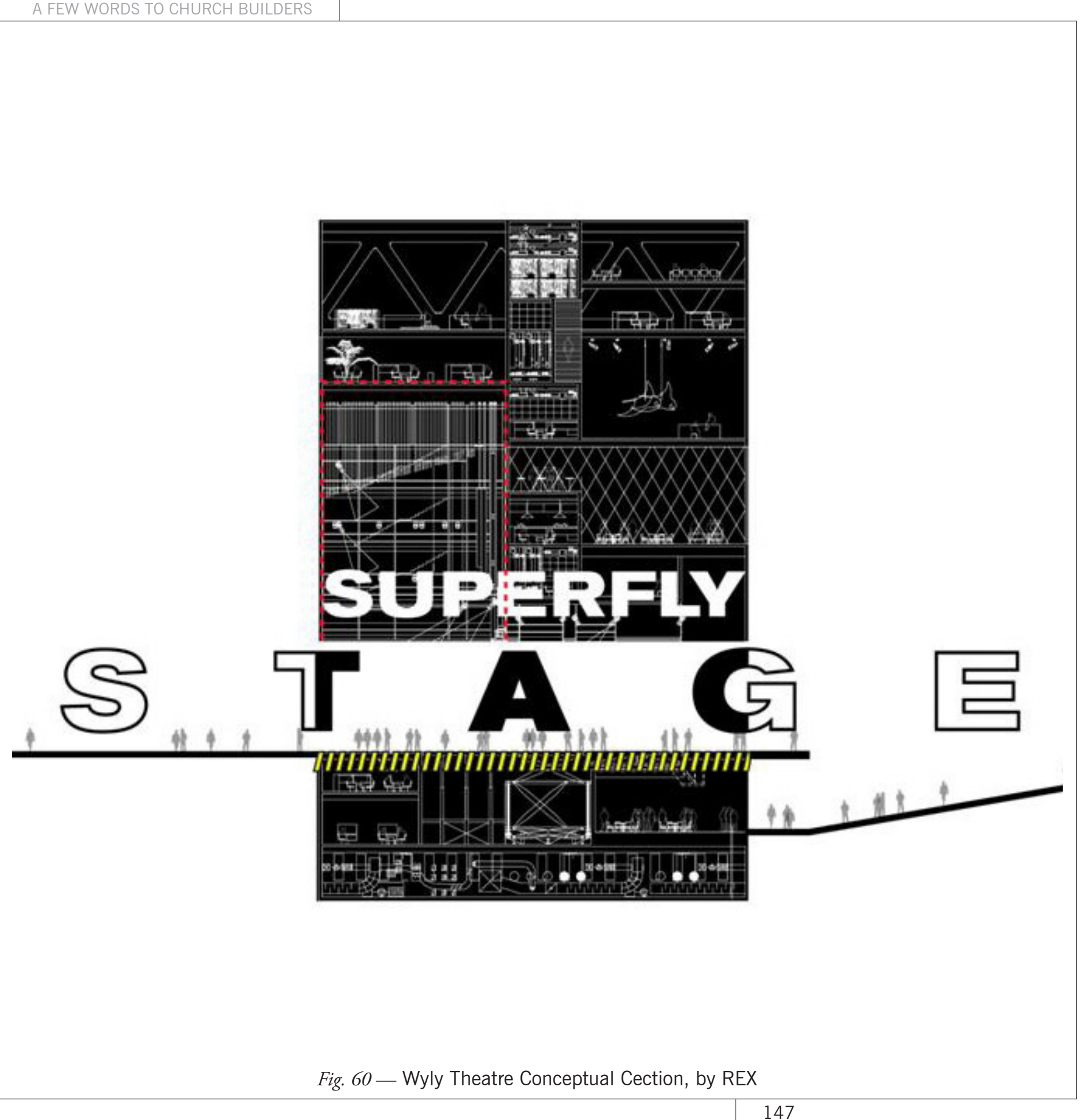


A FLAT

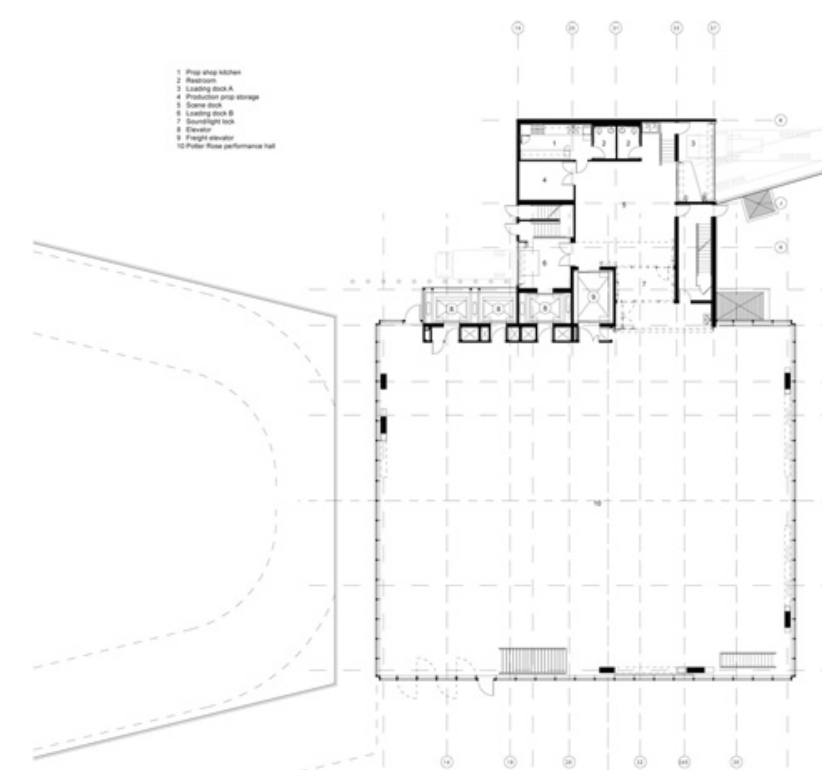

FLAT FLOOR

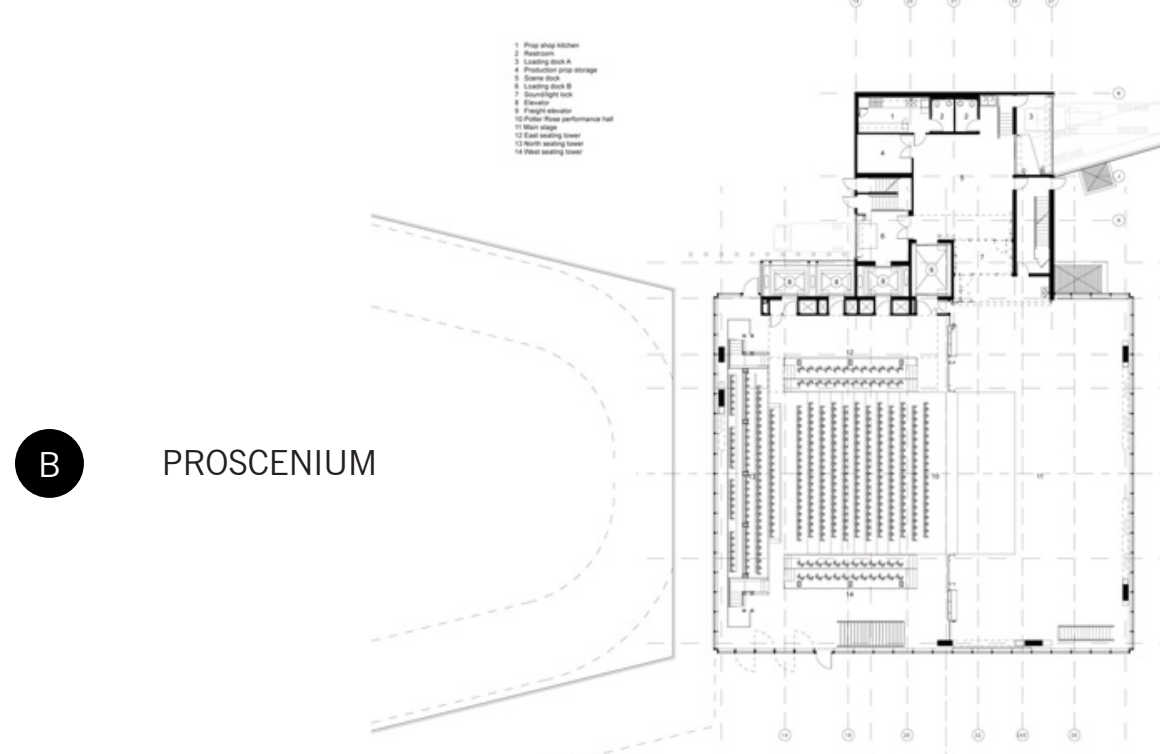

Fig. 61 - Wyly Theatre Auditorium Layout, Source in list of figures

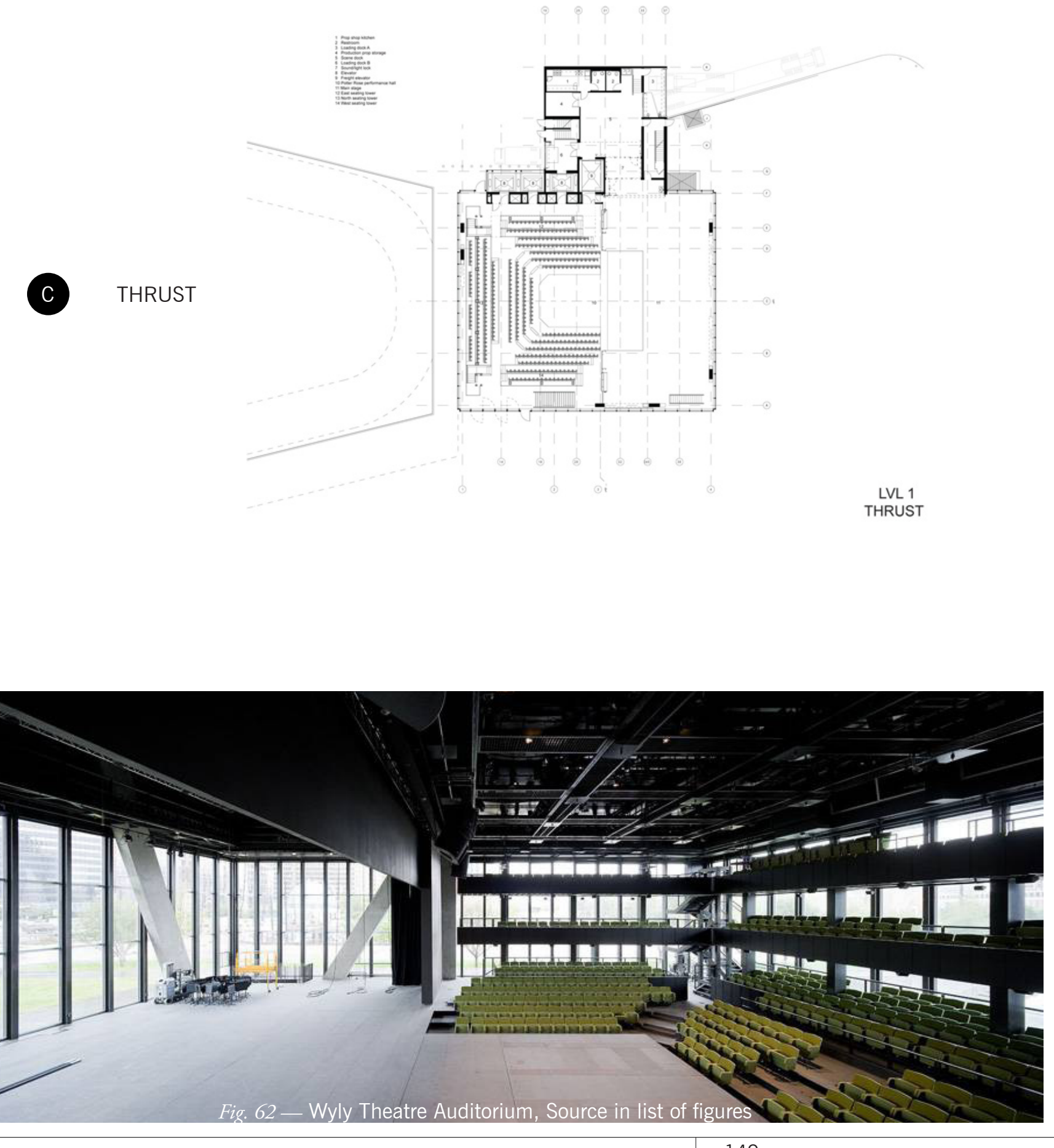

149 
The book Spatial Agency, offers a which builds upon itself, displaying different perspective from which to an inherent irregularity of design led approach architecture, the concept is research. Spacial agency informs a referred to by Joseph Razmus Prince following of an undetermined course as the injection of social engineering of action enabling a design conclusion into architectural systems. The book no one would be able to anticipate in question describes an attentiveness from the beginning.

toward aspects considered volatile to

architecture, such as the "process of production, occupation, temporality' ons to society and nature.

Here the thesis is reminded of process; subsequent design leading to subsequent design. Future design seeks to acknowledge the contingent aspects processes to consider contingen aspects of society. The architecture must prioritise the social condition in order to create an overlap of the secular and the sacred. Architecture is often limited to an association of 'object, tied to 'aesthetics.'

Spacial agency informs process 'Issue + positions $=$ architectural manifestation.' ${ }^{3}$ This thesis presents a process in a chronological order

1. Awan, Schneider and Till. 2011. pg 30

. Awan, Schneider and Till. 2011. pg 30

. Prince-Ramus, Joshua. (Oct 2009).

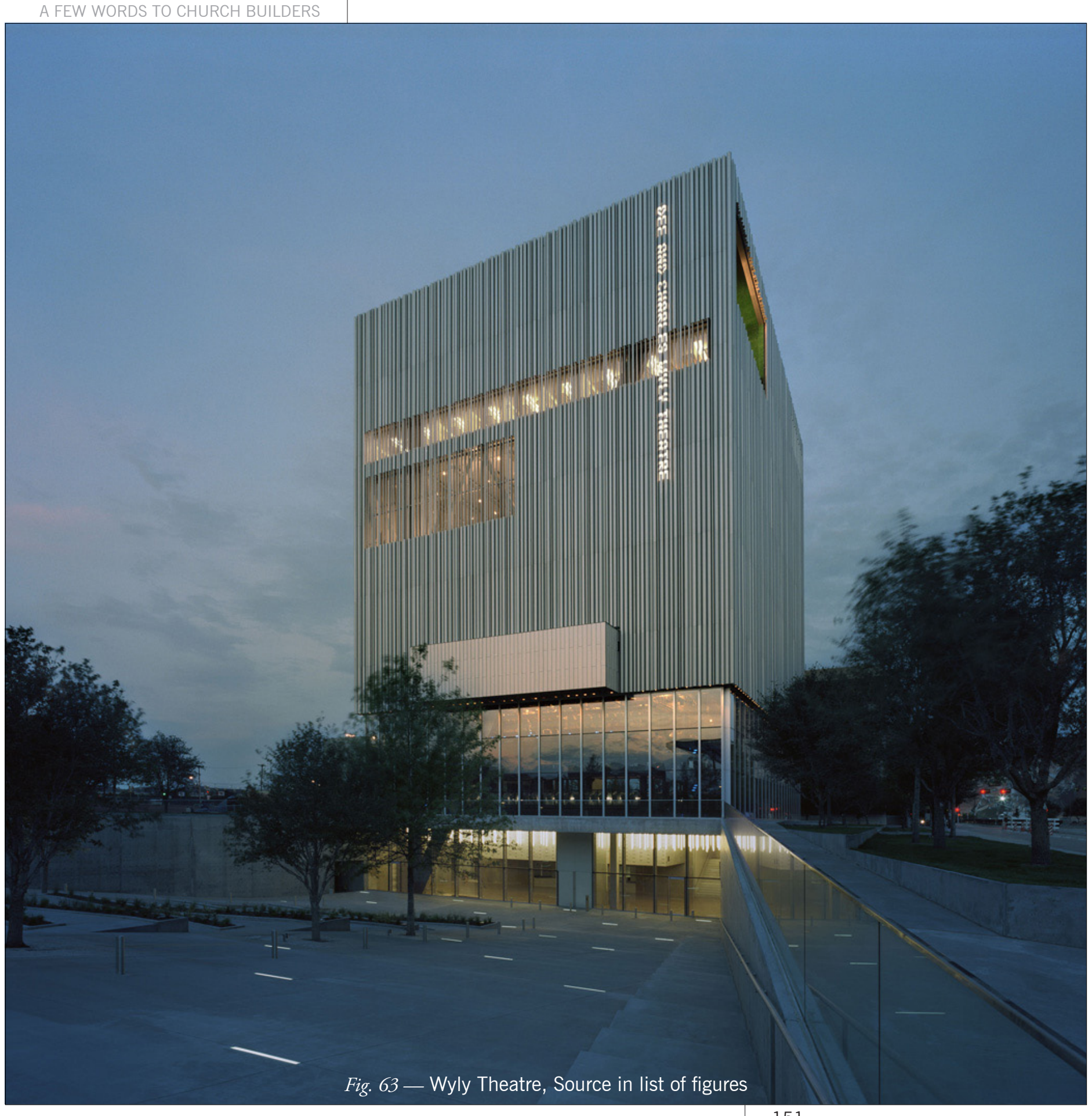


DESIGN

ITERATION

ONE 
The first design iteration tests Toyo Ito's moves attempting to fragment the theory of multiple program within a envelope and disassociate space with space to blur the perceived boundaries encounter. The convoluted method of the sacred and secular. The design is attempts to mechanically solve an an attempt to shift attitudes of place architectural problem. Stuck in a and enclosure towards the nature literal manifestation of 'expansion and of worship through an architectural contraction,' the unsuccessful design language of expansion and contraction. aids in the departure from literal

Fig. 67 a program diagram. The inclusion of a sports facility and CHURCH within the one structure is CHURCH within the one
programmatically arranged.

Fig. 68 discusses the habitation of CHURCH within the space, the render shows a porous wall behind the stage. This envelope is the only convincing architectural element success within this exploration.

Fig. 69 shows the building used by sport.

Fig. 70 a series of design iterations C- design, the building literally

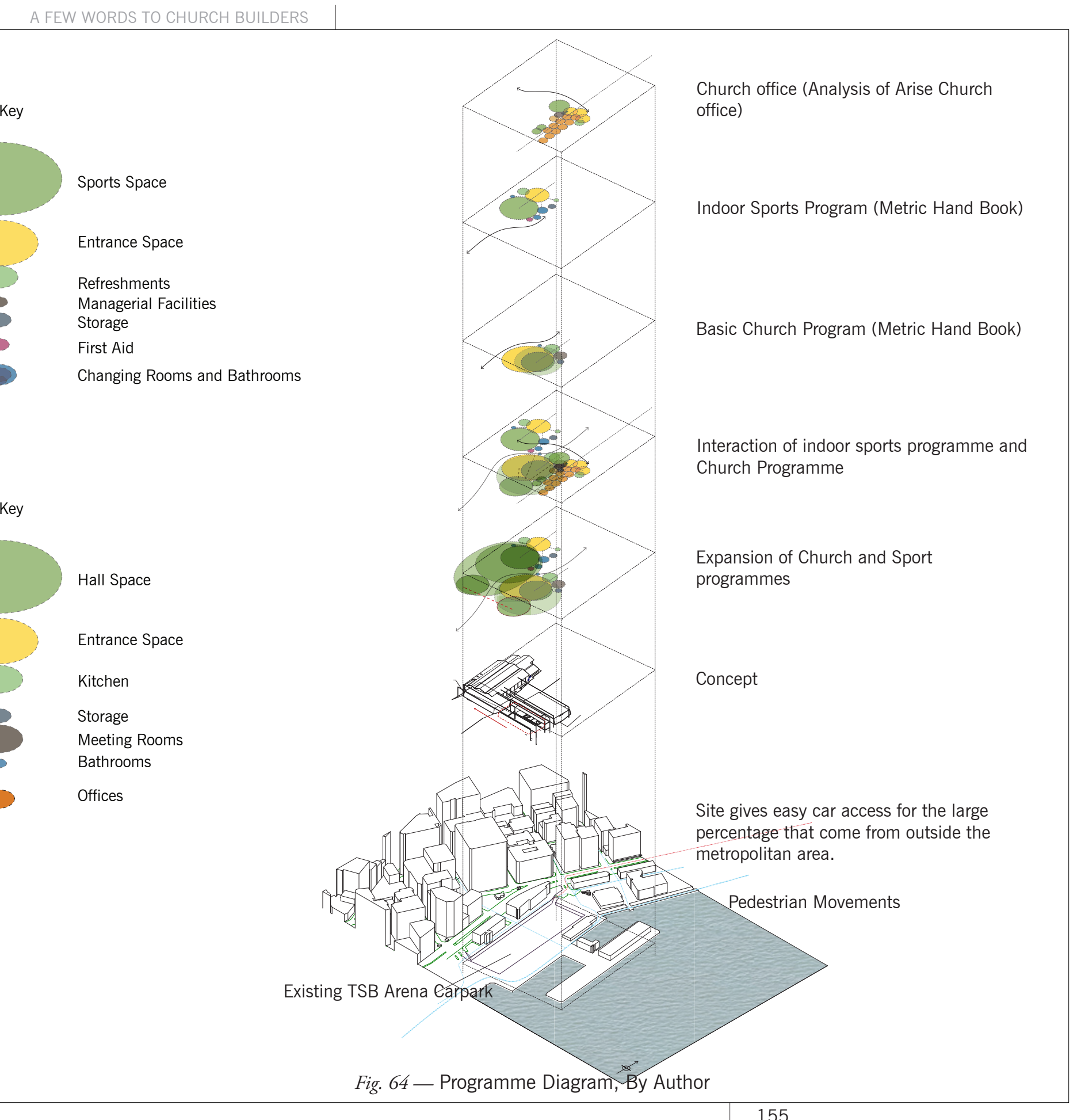




\section{AUDITORIUM}

AUDITORIUM
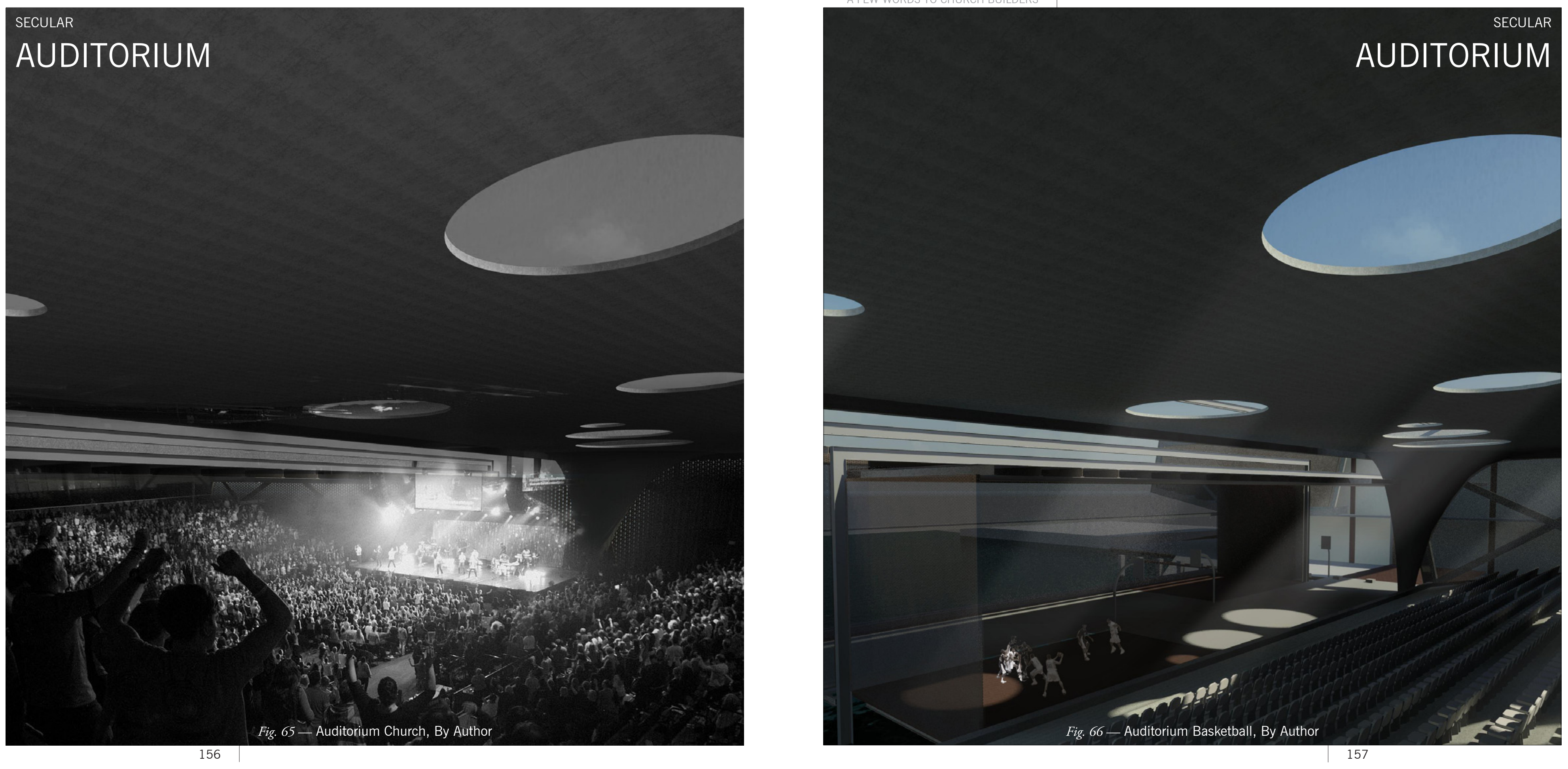


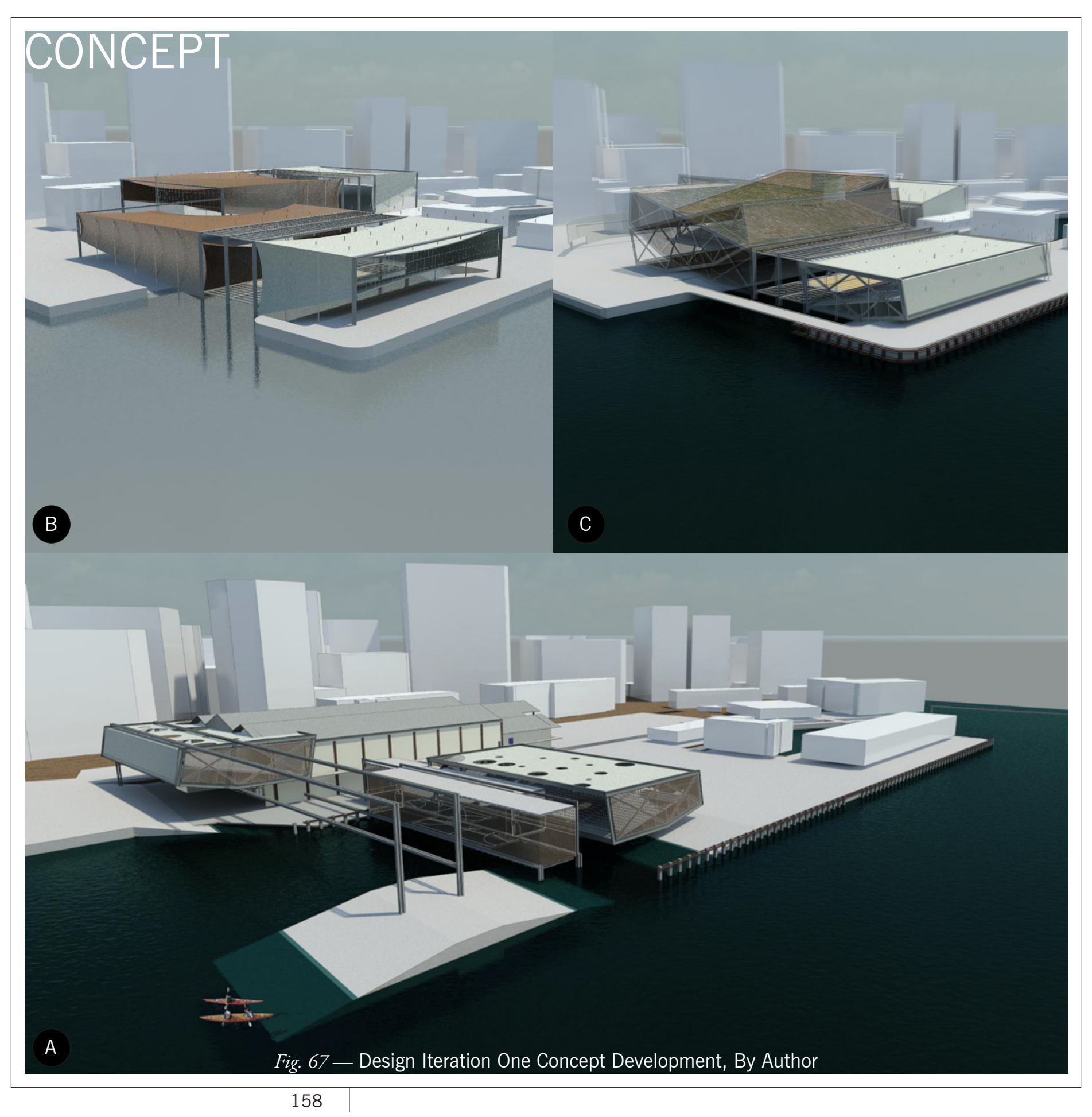

The first design phase overlapped

programme to blur threshold. The

design of horizontal form to express

immanence is tested. Design departs

from traditional architectonics yet

the roof cutouts are reminiscent of

symbolic iconography. The design

intervention is required to translate

notions of movement through envelope

and form rather than the literal. 


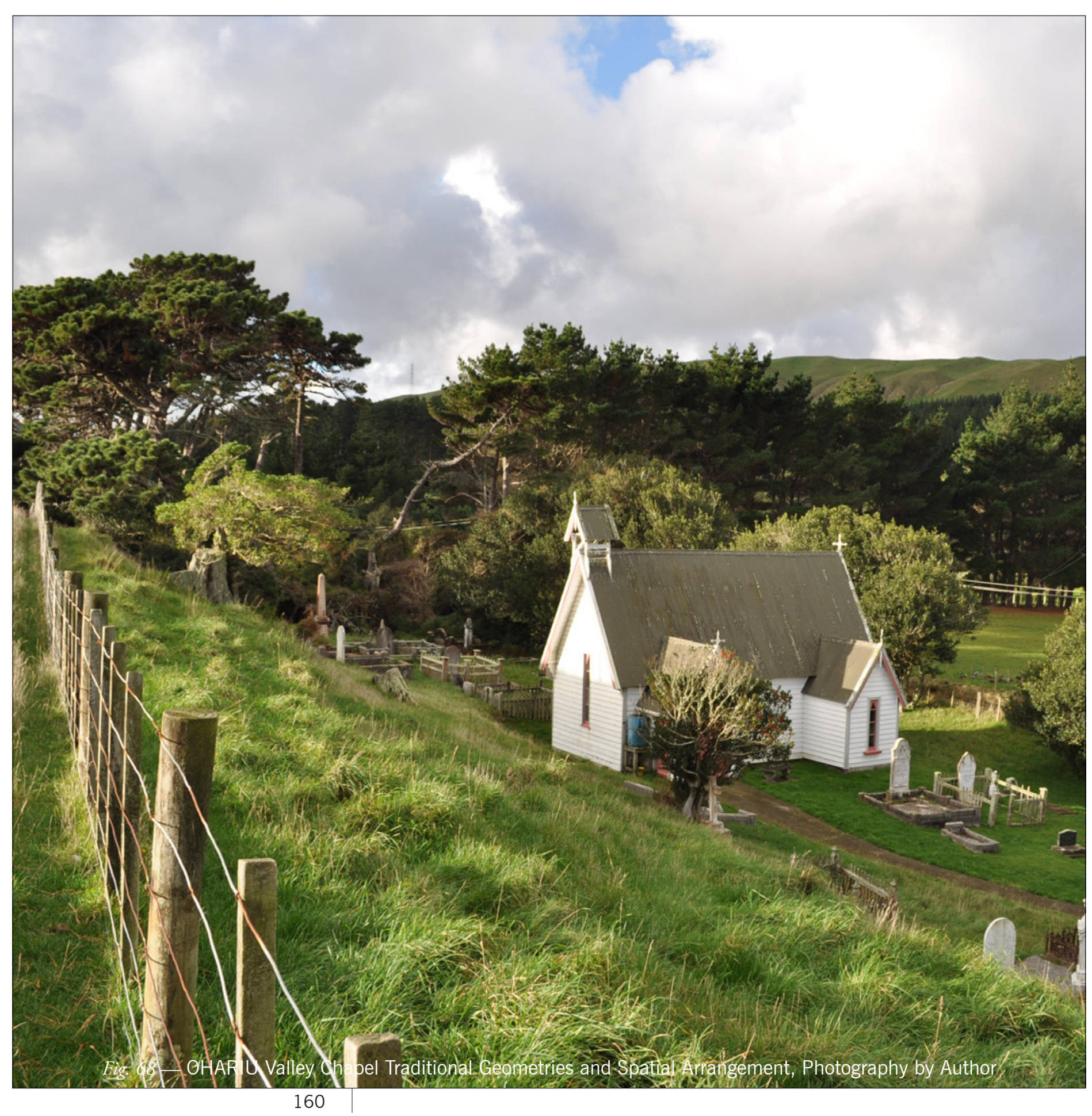

SITE SPECIFICITY 
The main proponent of con minication is regarded as visual. Traditional New Zealund CHURCH typologies (Gothic Revival, typically in wood) generally seek to represent their doctrinal understanding of God within their architecture through a performative display of transcendence and immanence. The traditional New Zealand Anglican Church typology Zealand Anglican Church typology could be considered site-less. The form and progranme vary little between rural and urban sites. Fig. 68 a rural Church outside of Wellington, which follows the same basic spatia geometries, spatial layout and direct approach to the altar as the Wellington Intercity Church fig. 69

The Pentecostal Church has no obligation to any obligation to any archisctura typology Un for built form to enge opportunty for bit forn to engage in the crukches fundamental purpose to share the Gospel, communicating with those in the immediate secular

1. Torgerson, Mark. 2007. pg 19 environment and emphasizing the presence of God in the midst of the real world. ${ }^{1}$ It is proposed here that it is ecessary for to $\mathrm{CHURCH}$ to be relevant a the secular culture in its context. In this project the ARISE CHURCH will sit in attempt to test these ideas.

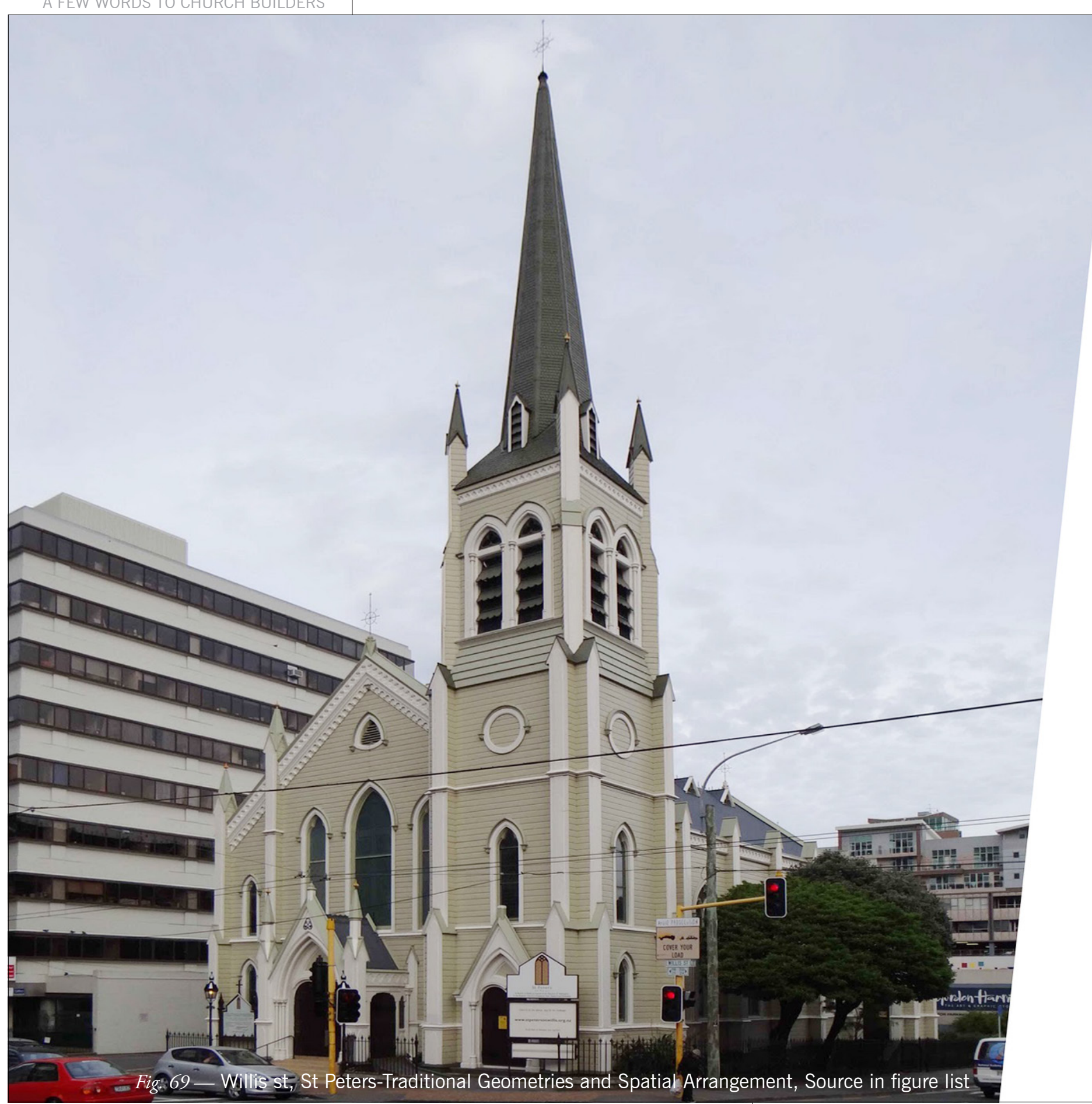


GESTURES

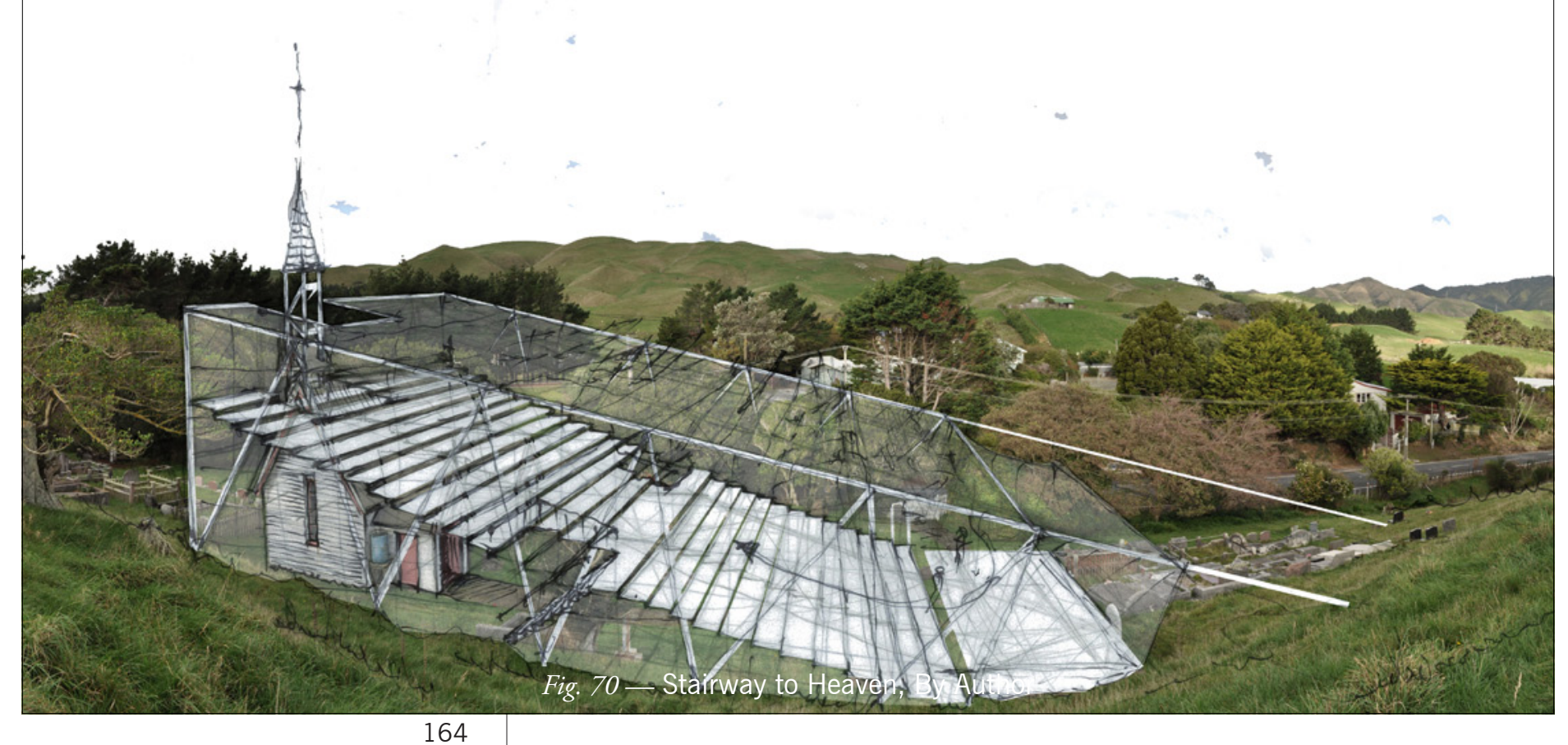


Formal gestures in Christian permeability of structure facilitates a architecture are typically of the visual connection to inhabited areas transcendent, pointing vertically in of the structure. Although inhabited reference to God. several levels above the ground, access is perceived attainable due to visual Fig. 70 a design exercise, develops an connection and understanding of interplay of two architectures one of context in its entirety.

secular and one sacred. Together they form a reference to the attainability of God. Design takes a traditional chapel and places an auditorium rake (hapel and places an auditorium rake (reminiscent of stairs) on top. The design combines the transcendent nature of the spire expressed by its verticality then applies immanence the rake of seating acting as a staircase making the transcendence visually attainable. The applied form secularises the traditional Church, the language is almost destructive, belittling of the small chapel through placing a large mass on its head.

Fig. 71 the corresponding precedent expresses attainability in a similar way to the design exercise. The

This exercise informs use of external skeletal structure in design. It seeks to allow an understing of to exterior perspective. ARCHITECTS 


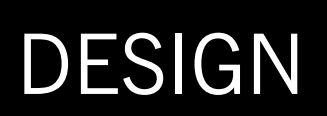

DESIGN

ITERATION

TWO 


\section{INTRODUCTION}

Designiteration two combinesreceptive Fig. 72 depicts the simplified threshold

form and a permeable envelope in of iteration two. The tapering facade order to blur the boundary between drags the building down to a human the sacred and the secular. Through the scale - increasing intimacy with those application of these devices the Church in proximity. Visual sight lines to the envelope is dissolved, dislocating space stage pass through the open ground from encounter and shifting spatial floor envelope, whilst the raking perception.

balcony envelope creates a porous upper volume. Previous design experiments suggest sacred Fig. 73 shows a series of nodes around distinctions could futhl the theological the building which activate the site requirement of an external focus. beyond Sunday services. A dual Sovik suggests that to remove sacred function of post service congregation connotations and perceptions of break down and programmatic secular worship relatable to things or objects, insertion is achieved through the use places the focus on God and people of cafes and restaurants.

rather than God and place. The form

and envelope that contains the liturgy Fig. 74 details the porous envelope of has an opportunity to represent and the auditorium.

facilitate these theological stances. The

concept "cloud

Fig. 75 graphically depicts the existing iteration.

$$
\begin{aligned}
& \text { Fig. } 75 \text { graphically depicts the existing } \\
& \text { ARISE congregation in terms of people } \\
& \text { associated with each part of the church } \\
& \text { whether pastoral or congregation. }
\end{aligned}
$$


Fig. 76 , a south west perspective representing the architectural manifestation of Iteration two. Form and envelope are seen to manifest the theological stance and ARISE CHURCH into the existing structural frame of the TSB Arena. The Church facade facilitates a visual dialogue between

the interior space of worship and the

exterior secular thoroughfare. The

facade, informed by the auditorium balcony places th at the base of its rake allowing a visual permeability not only through the space of worship but the building.

Fig. 77 illustrates the auditorium from inside the south entrance, highlighting an ethereal fabric 'cloud' which conceals the upper tiers when not in use. Projecting out of the building the ce. Projecing out of the bilding, the cloud operates as a physical symbo ntainable nature
Fig. 78 stage is positioned to face approaching foot traffic from the south. The tapering balcony as envelope allows a proximity of public as close to the stage as balcony patrons. This overlap contributes to a blurring of threshold between the secular and sacred.

Fig. 79 the threshold seen in fig 72 is continued in the east and west walls. As a result the auditorium's narrow width allows a visul tanspreng. The ground floor is lowered to allow an unobstructed view from the public thoroughfare to the stage or through the building. 

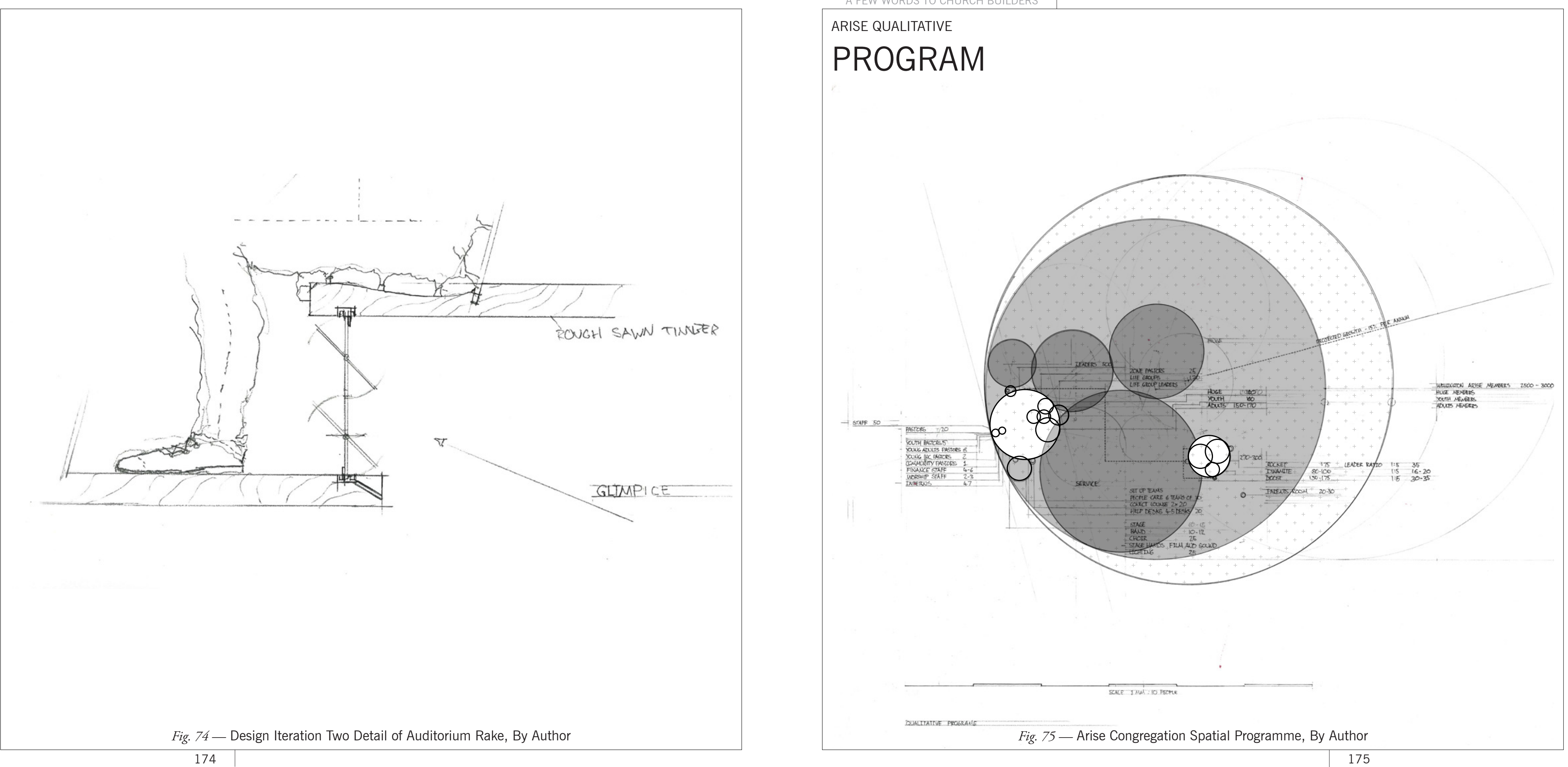

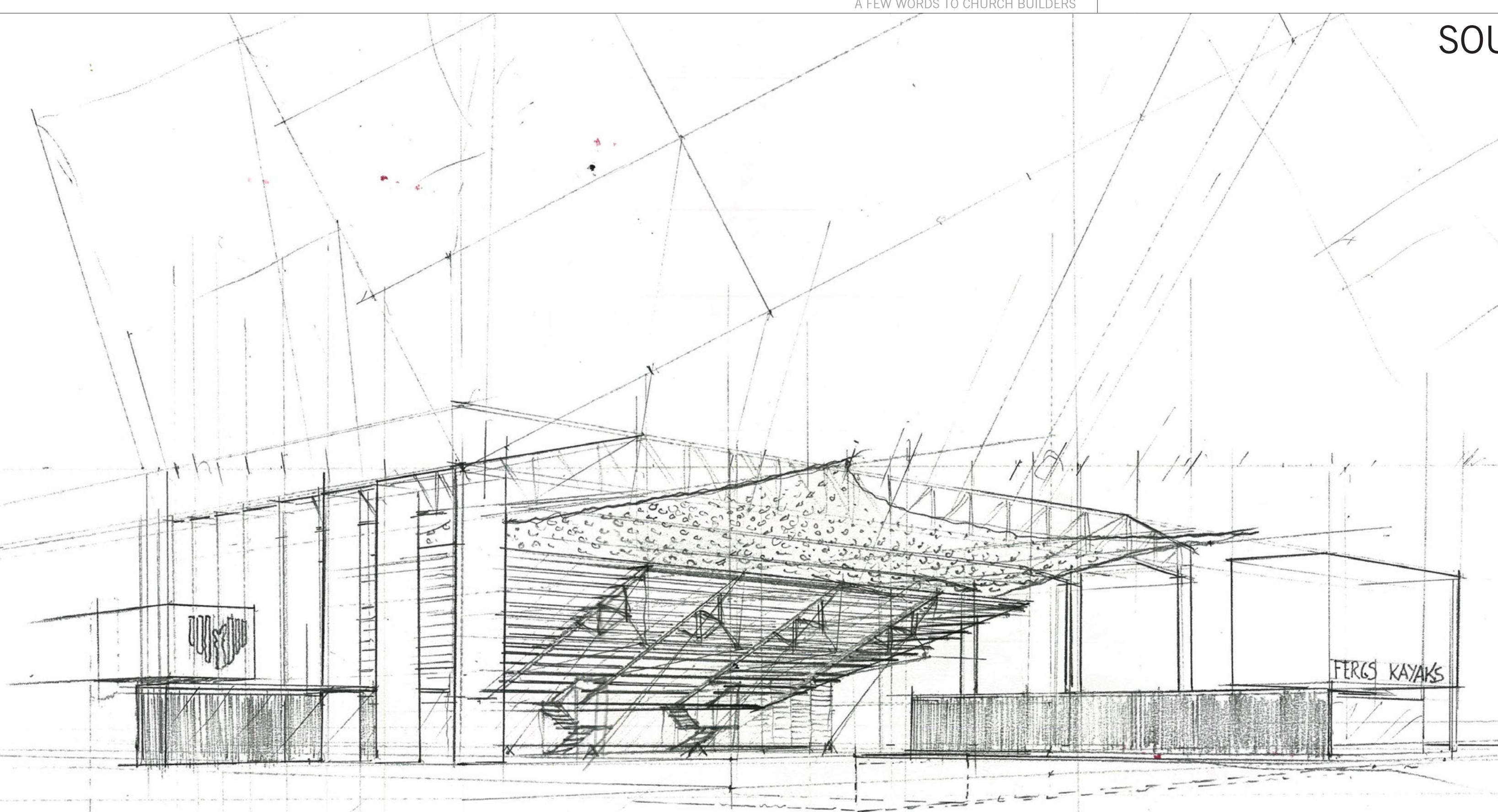


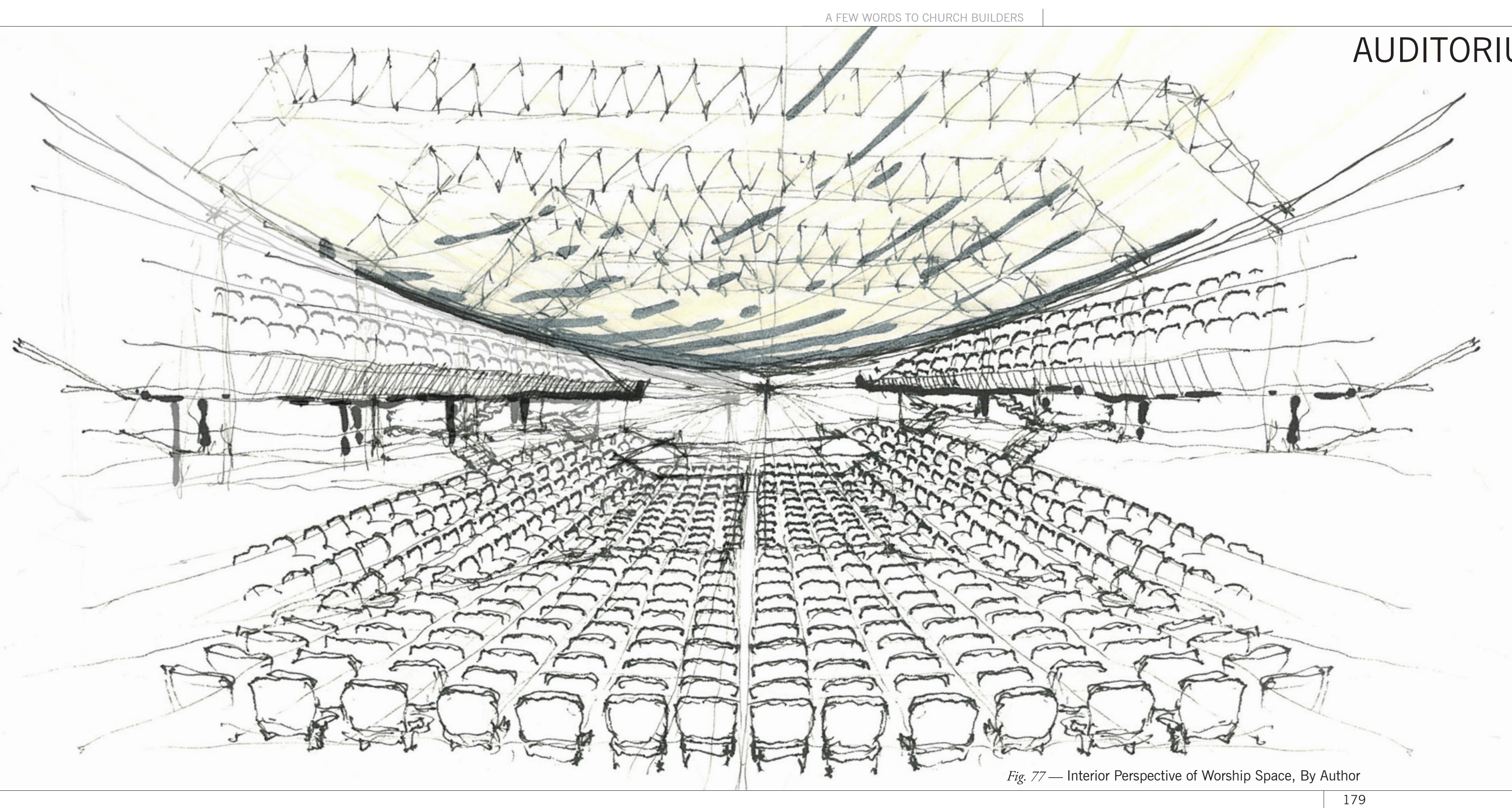




\section{LONGITUDI-}

NAL SECTION

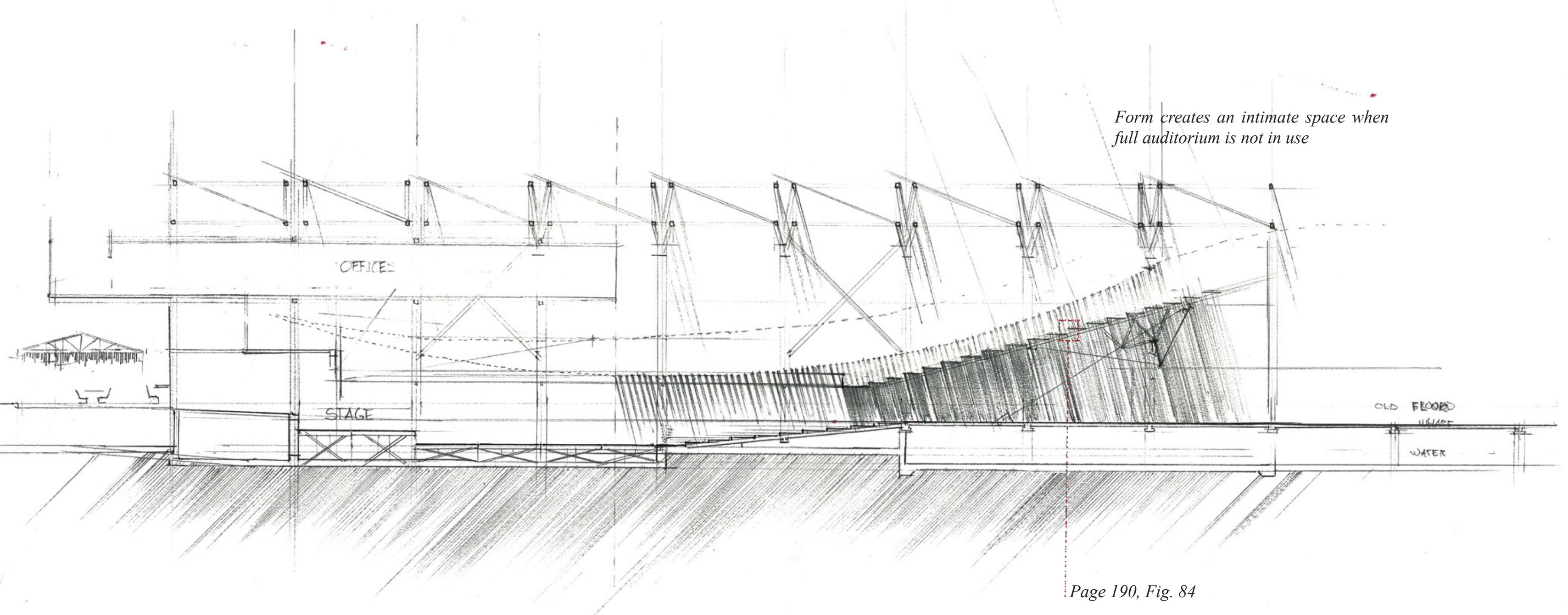




\section{TRANSVERSE}

SECTION

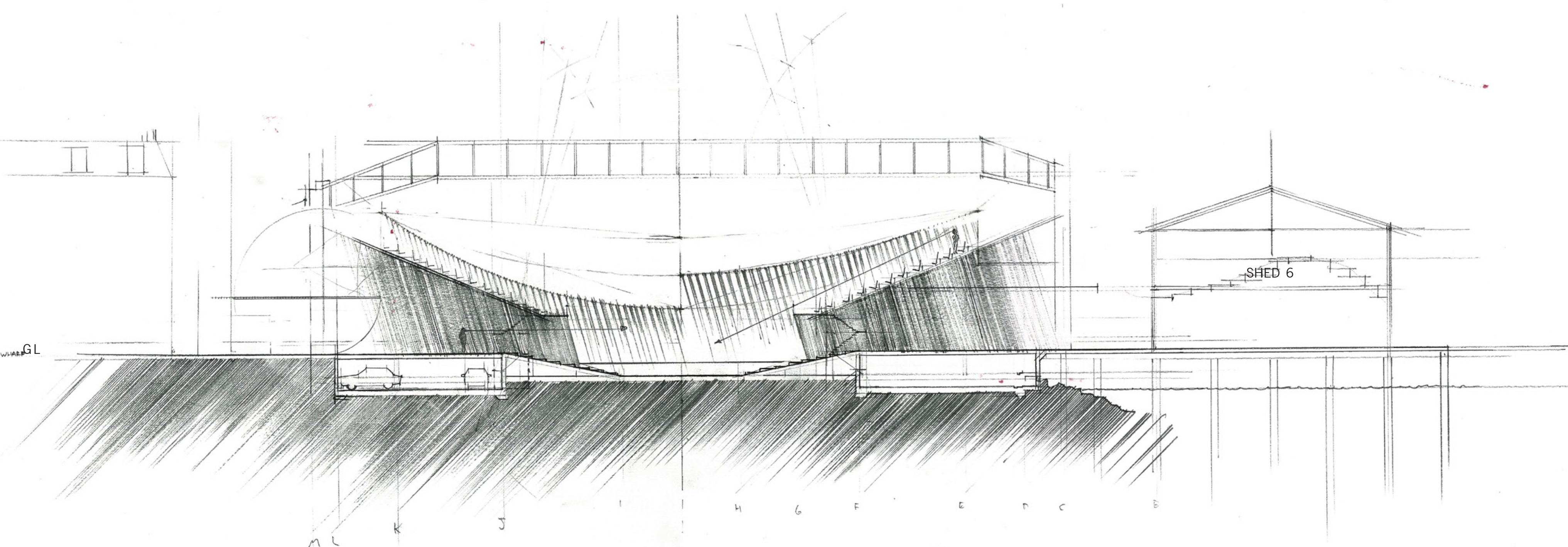


The inclusion of a public thoroughfare

under the auditorium balcony (within

the building) allows the secular

environment's proximity to the sacred.

Combined with the concept of secular

programme nodes it could achieve a

secular and sacred blur of threshold.

The use of programme as a tool to blu

thresholds will be later tested.

The 'cloud' extruding out of the building highlights the notion of containment and disassociates an

association of worship to space.

This concept informs future design

investigations.

Fig. 80 critiques efflux of CHURCH upon

the site through a graphical analysis of

overlaid drawings.

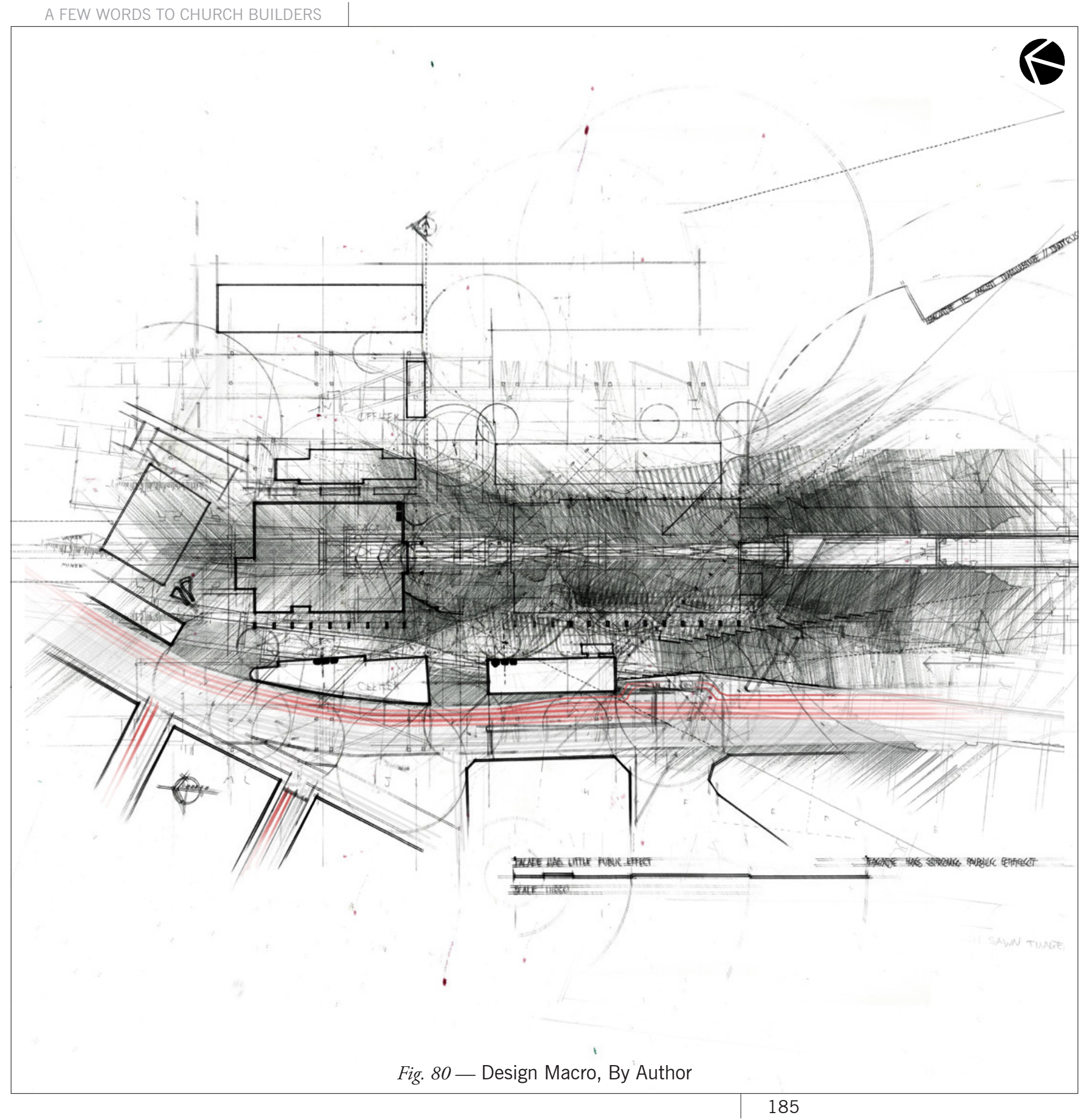


NISHIZAWA

ARCHITECTS

\section{PRECEDENTS}


ARISE CHURCH attains to the theological stance that the presence of God is not confined by architecture. The Tomochi Forest Hall by Taira Nishizawa and concert hall in Kristiansand, Norway by ALA Architects act as precedents manifesting absence of containment, evoking a release.

Fig. 81 Taira Nishizawa's sports Hall creates an inclusive creates an inclusive relationship between inside and outside through visual connection although restricted at ground level. Nishizawa said in a lecture held in Wellington "only a ball would be thrown up into view." The connection between inside and out is created by form envelope and inhabitation, the view of the 'ball' describes the event, while the exposure of the structure allows an understanding of the internat conse before entering.

Fig. 82 ALA Architects' theatre and concert hall, embodies an architectural

1. Nishizawa, Taira. (2012 May 22).

form which links the exterior and interior spaces. This is achieved through the continuation of form through the glass facade. It is proposed that the expression of an internal form to the outside evokes the notion of release therefore portraying the concept of efflux discussed earlier.

Design iteration three will test this architectural strategy. 


\section{DESIGN \\ ITERATION \\ THREE}


An 'uncontained' emphasis on Fig. 84 in perspective section illustrates 'Christ's presence' informs envelope, the building envelope; as auditorium influenced by Nishizawa and ALA balcony, ceiling and facade. The Architects, previously examined work. envelope is embodied by a wooden Form manifests a release through a form acting as structure and envelope, permeable fractured envelope, this the form extrudes beyond the interior communicates the notion of efflux. enclosure manifests the notion -

To disassociate place with encounter, a fragmented uncontained structure will This iteration engages further with encompass both secular and sacred detail and materiality. Wood is used spaces. to express familiarity, 'If a material looks like anything, it looks like itself: The stage is located on the west wall no material should claim for itself the allowing a larger thoroughfare on the form of another.'

eastern wall for the secular to move north and south along the wider waterfront. This orientation also allows

people to flank the stage indirectly, in a

less confrontational entry.

Figs. 84-85 earlier design investigation informed a cause and effect between interior and exterior environments. The forms on the outside correspond Fig 83 expresses the Church's to forms on the inside, combined Fig. 83 with the porous envelope design narrative, existig mon gives people outside an accurate understanding of what they will expect upon entering the Church.
Fig. 85 clearly reveals the porous envelope by the fragmented light shown to enter the space.

Fig. 86 shows the relationship of the worship environment pulling the external thoroughfare (under the auditorium balcony) as far into the space of woship as possible. The form connecting the balcony to the ground provides access to the balcony. 


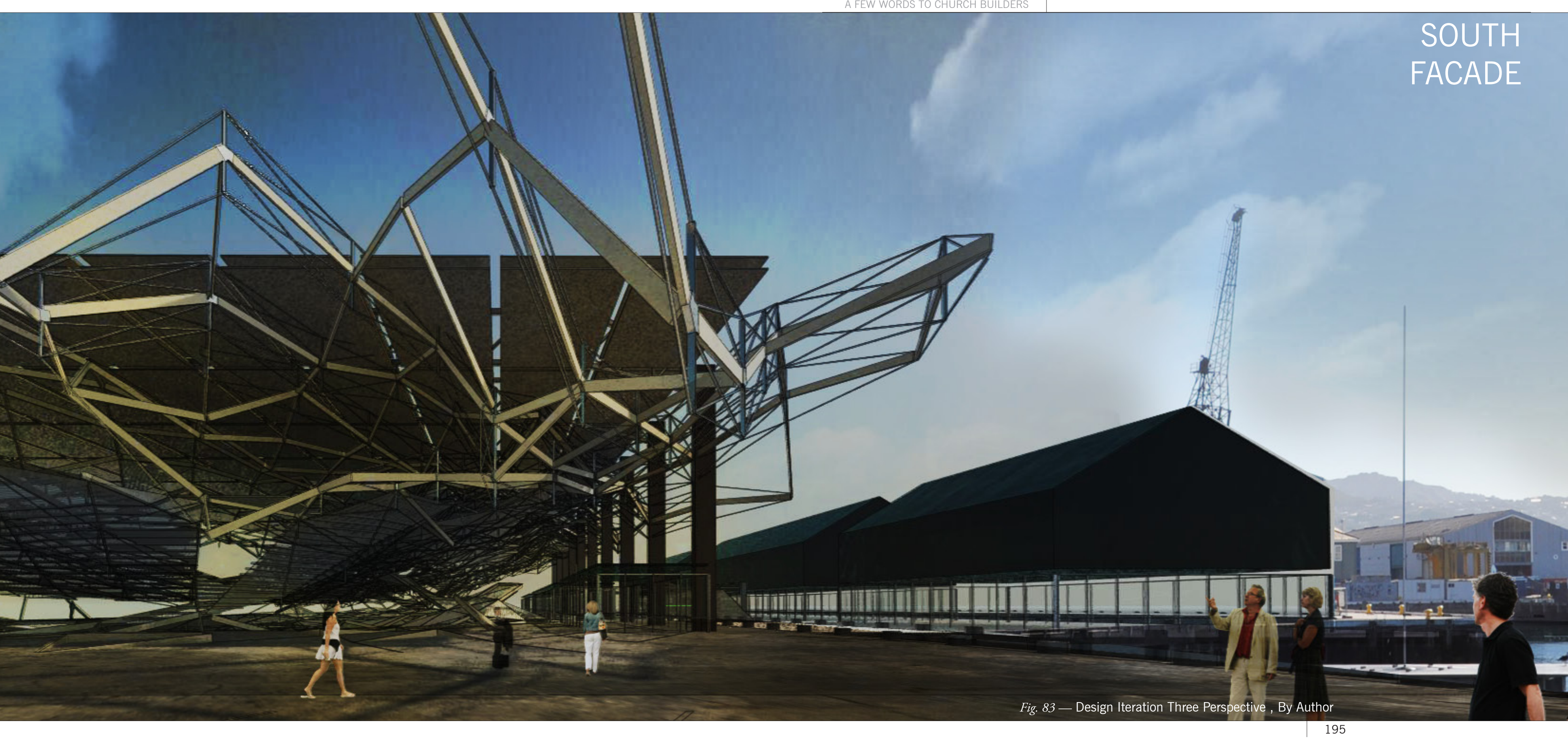




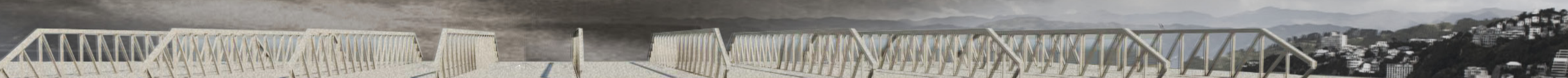

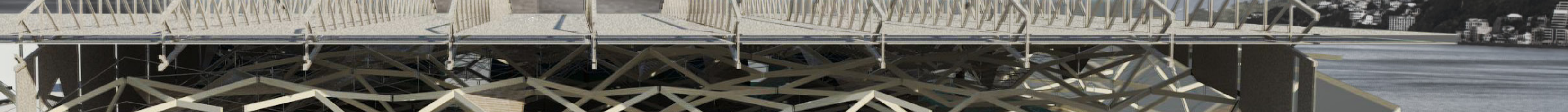

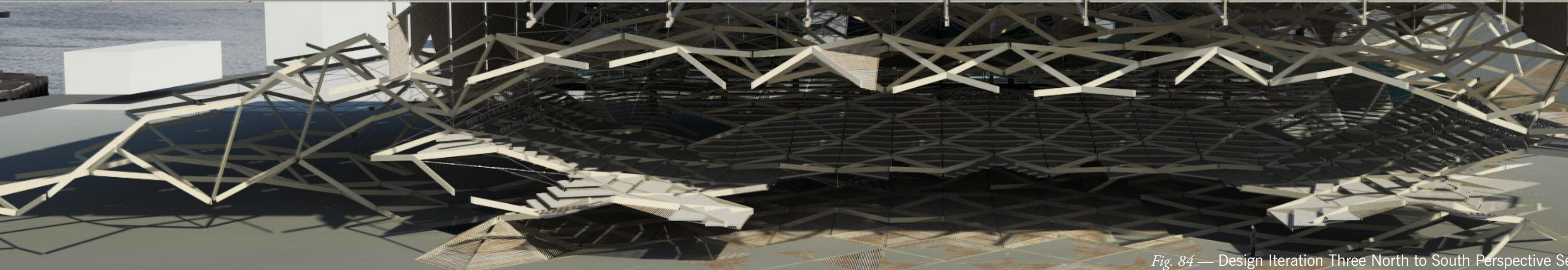




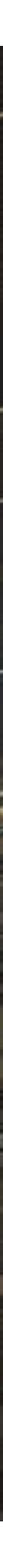


Though design iteration three an

accurate architectural depiction of the

release emerges. But the architectural

solution fails to integrate with social

contexts. The complex form contrasts

dramatically with the monolithic

language of the surrounding context.

Earlier analysis discusses a Church

integration receptive to social contexts.

Design Iteration Three emphasises the

inve

need to ing the the secclar though

insertion of programme giving

opportunity for the envelope to

express a discussion between sacred

and secular. 


\section{JESUSHOPE EOR}

\section{PRECEDENT}

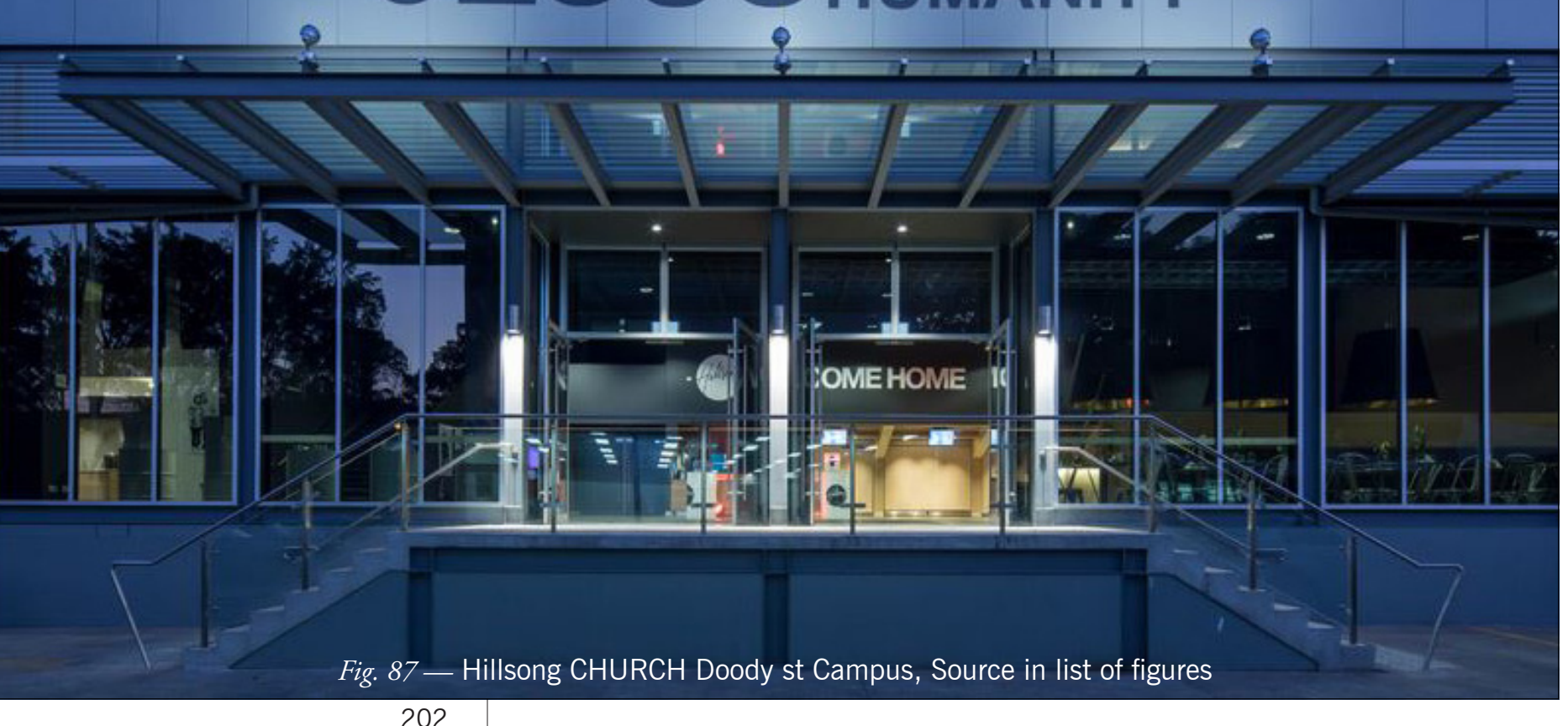


"Hillsong City Campus (Doody Street) is a vibrant urban hub providing a platform for an energetic Christian community.

The church space is a converted warehouse that includes a 900 seat church auditorium with state of the art $A V$ technology, several breakout meeting spaces and an edgy, welcoming entry foyer."

$$
\text { NBRS PARTNERS }
$$

In June 2013 the Author visited this and other Hillsong, Sydney campuses. Retaining a similar theological to black. The auditorium is designed to facilitate a theatrical environment but perspective to ARISE CHURCH, Hillsong pallet affirm a separation from the CHURCH is also unbound by a canon of architectura cite. Doody $\mathrm{St}$ campus (figure 87) is seculr in form the only iderif the only identification a steel cross on the roof and a text based sign reading 'Jesus Hope for Humanity.

The foyer with cafe style layout The foyer and worship space are addresses the side street it faces. Its threshold is designed to engage the materiality includes light colours and foyer and cafe into the worship pale polished concrete. The function space; the consistency of materiality of a cafe mediates the secular activity contributed to the threshold blur. of a cafe mediates the secular activity with the prome of sared pallet affirm a separation from the The foyer includes familiarities to the secular, such as the smell of coffee and the sound of people talking.

The foyer and worship space are

church realm. This space relates well to

the street but contrasts with the space
of worship. Material palette is reduced

1. NBRS+PARTNERS 2013

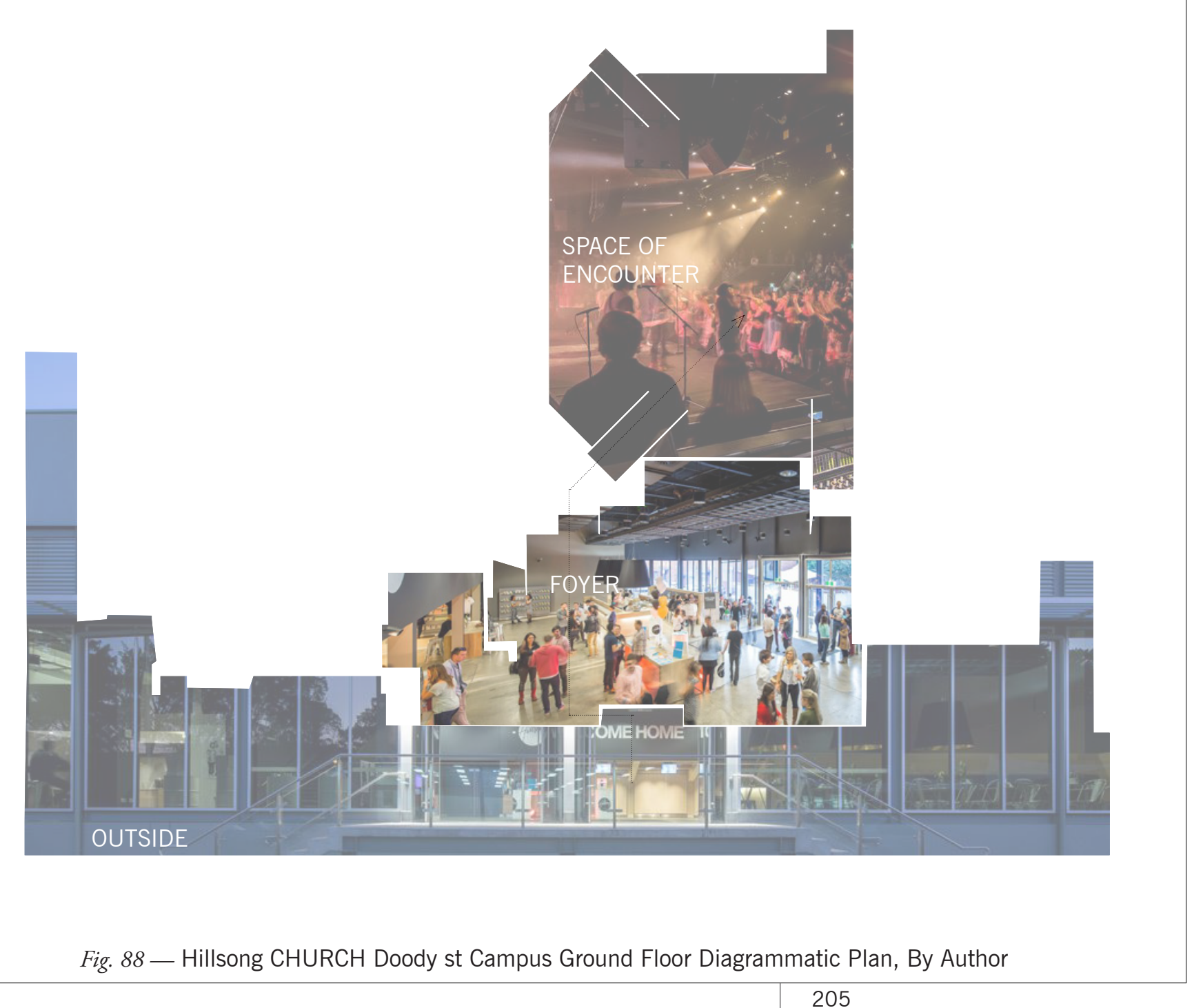


FIRST FLOOR

PLAN

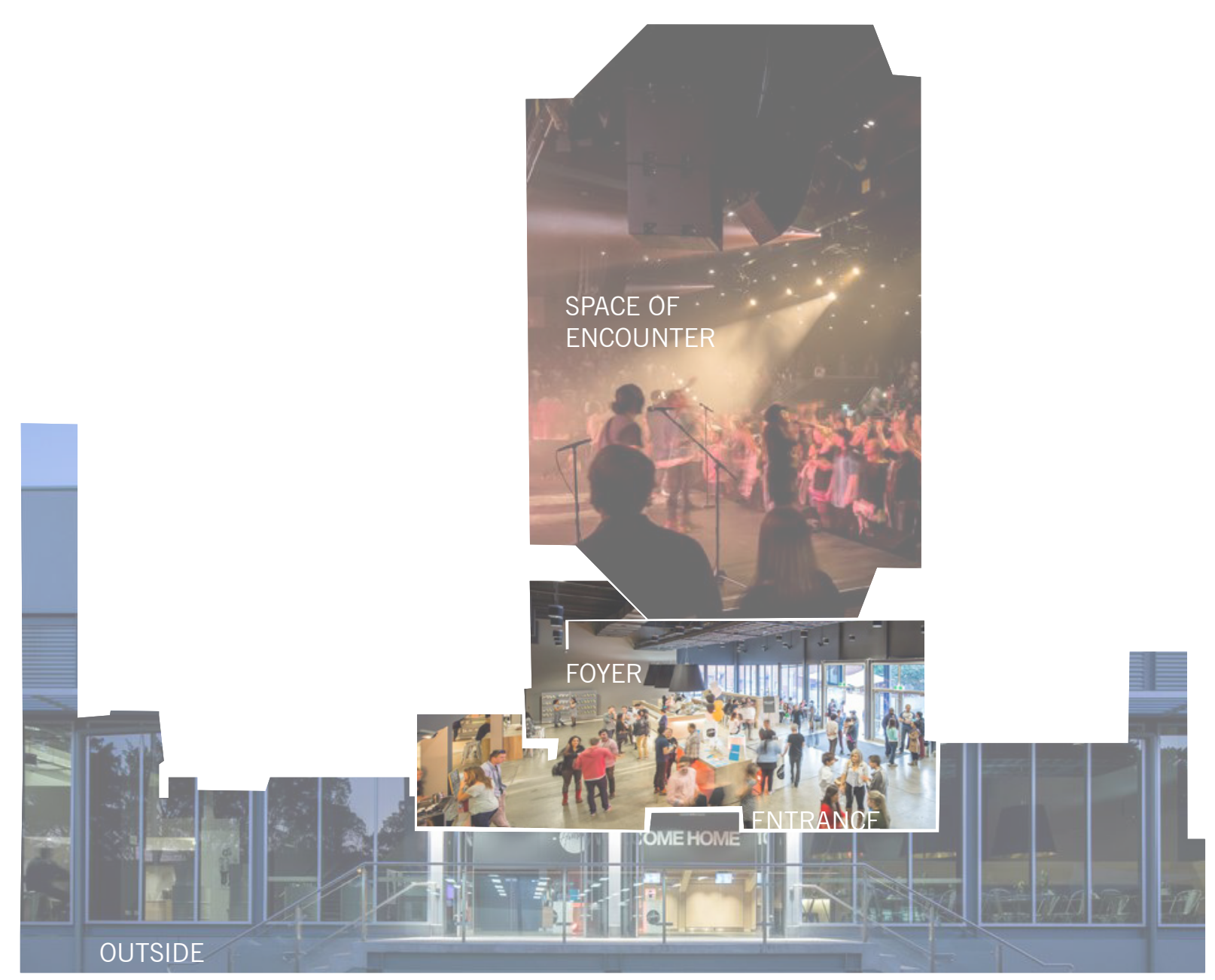

Fig. 89 - Hillsong CHURCH Doody st Campus First Floor Diagrammatic Plan, By Author

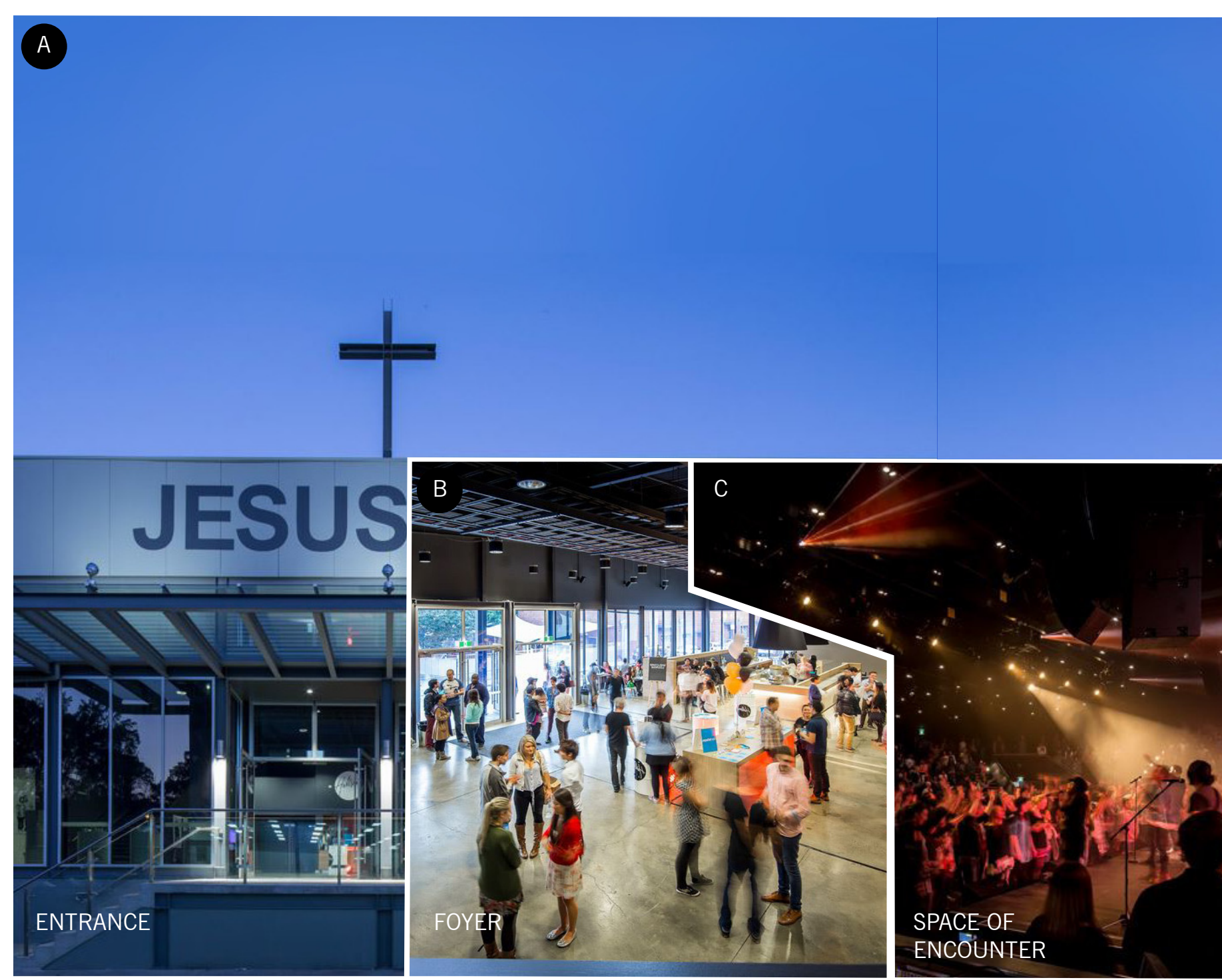

Fig. 90 - Hillsong CHURCH Doody st Campus Sectional Collage, Source in list of figures 


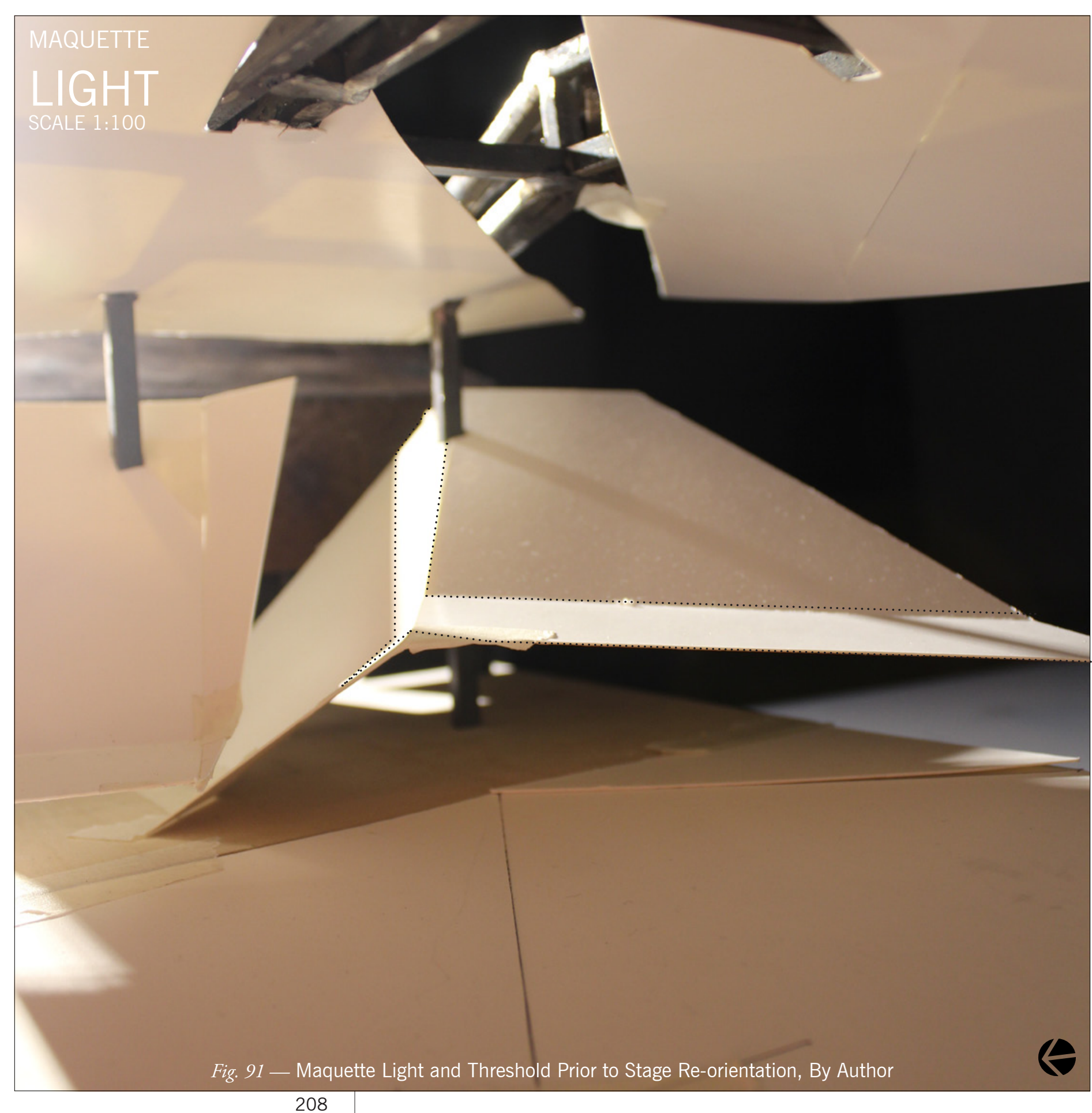

LIGHT AND THRESHOLD 
The apparent lack of consideration to leakage between auditorium and the light in the threshold between foyer outside. This emphasis is the role of and worship space in the 'Hillsong threshold in the separation of worship Precedent ${ }^{2}$ initiates this next section.

Traditionally light is a significant Fig. 91 explores light in threshold. theme in religious architecture. Many The design investigation develops architects design Churches around auditorium balcony stairs whose the channelling of natural light since tangent radiates from the stage to limit the che the thit medieve visual obtrusion fou The such as such as Ronchamp by Le Corbusier or Wellington's Futuna Chapel by John Scott.

By definition dark is the absence of light. The church is referred to as the light of the world in Christian theology. Pentecostal CHURCHES like Arise typically operate within enclosed environments. The absence of notural light allows full contol ore mood and atmosphere by the use of artificial lighting. The vomitory, (the passage that is walked through when entering a theatre) ensures no natural light
Fig. 92 changes the direction of the stairs. The form allows sunlight to fall on the base of the stairs (morning service). The design challenges the presence of natural light entering the worship space. Subject to external conditions the congregation are reminded of the external focus held the could Light breaks the solidity of the structure cutting through the threshold of sacred and secular. conditions

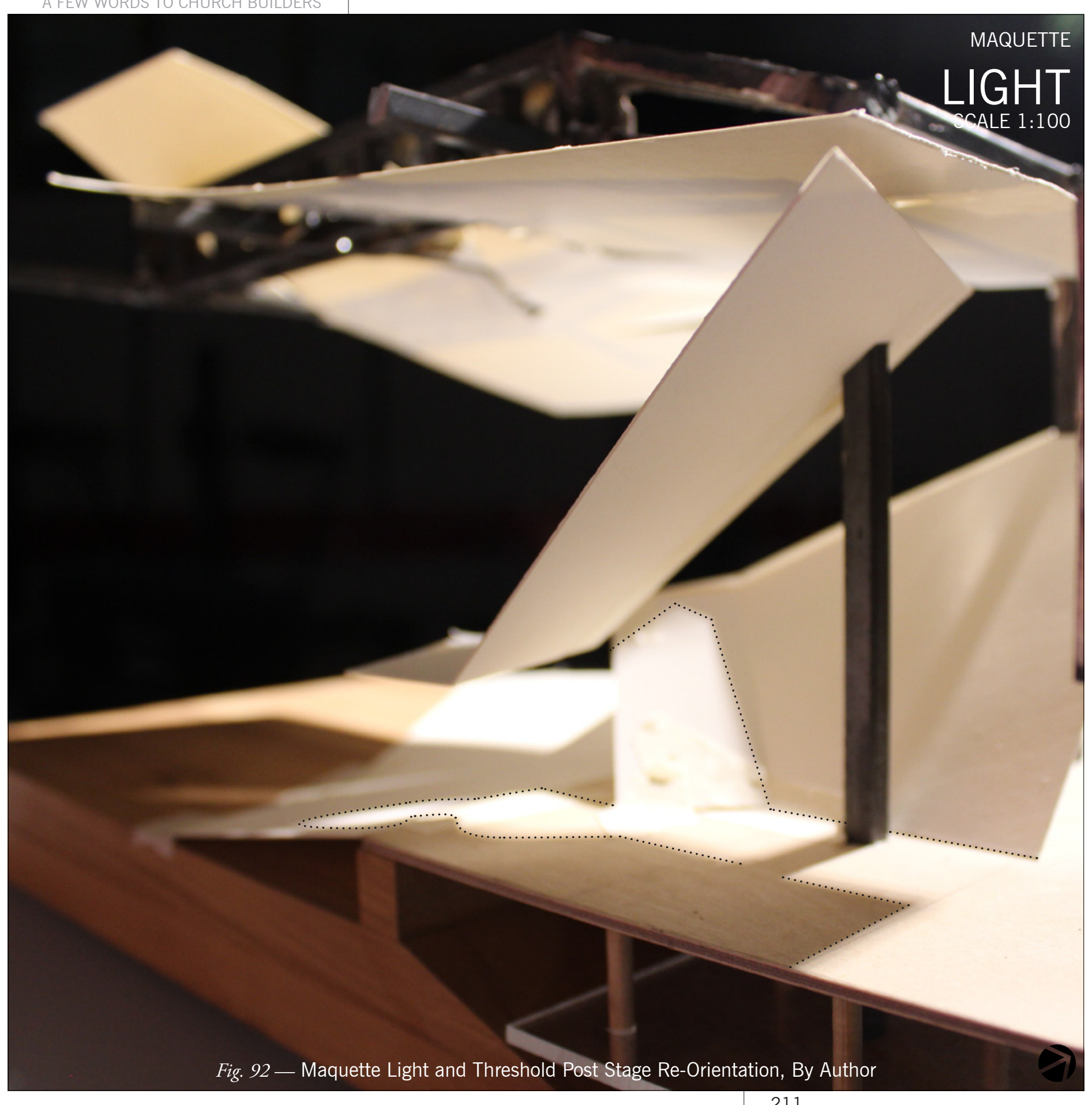




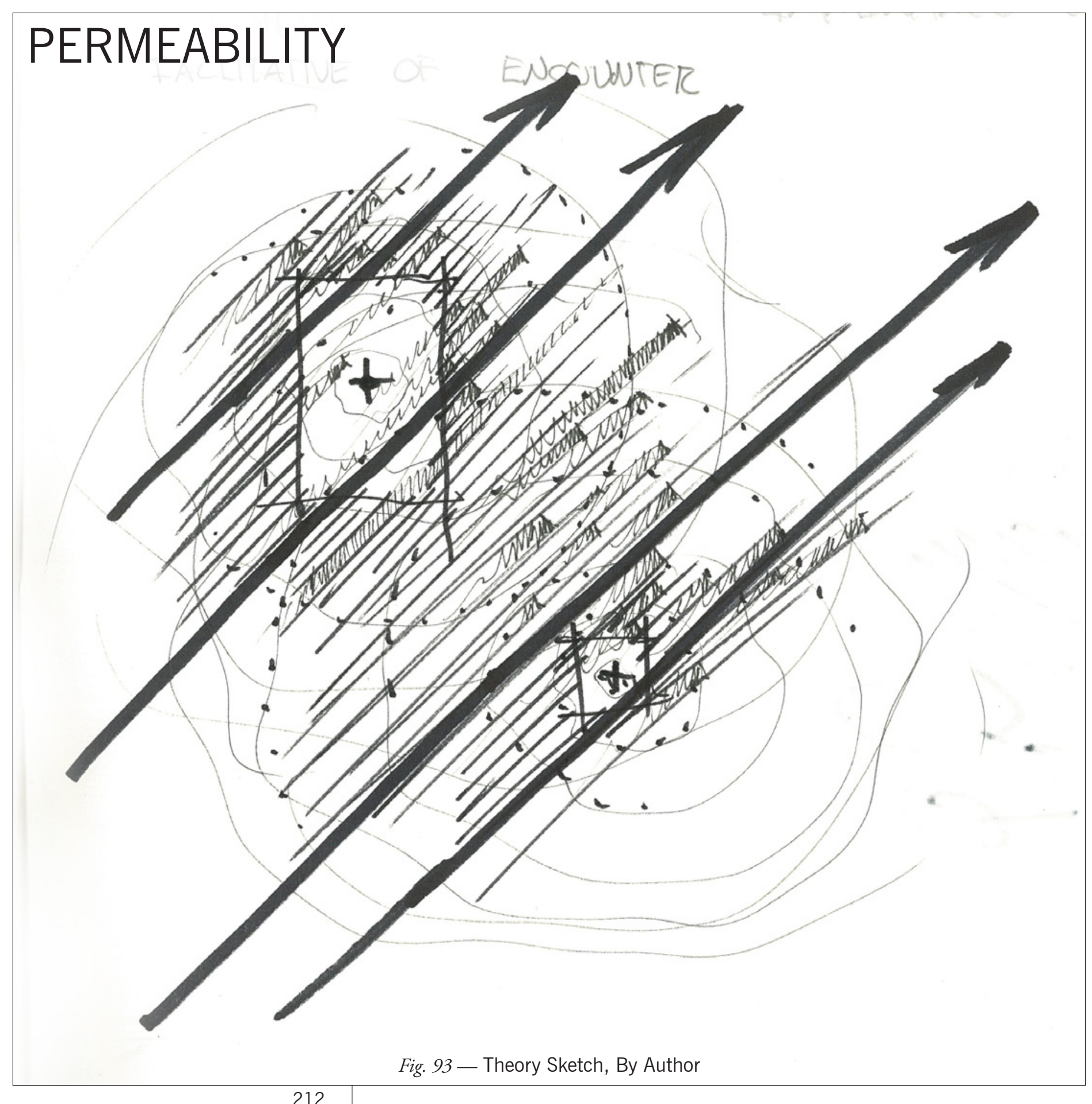

EXISTING THRESHOLD ANALYSIS 
This investigation critiques threshold with Wellington within Wellington Churches, both traditional and contemporary. The following drawings inform an indirect approach to the focal point (stage / altar).

Fig. 93 sketch informs a secula permeability.

The following drawings critique the permeability of entrance to the street through a graphical hatching analysis. Hatchings are offset $45^{\circ}, 90^{\circ}$ and $135^{\circ}$ from the street (secular environment). This method of threshold critique is the same as Fig. 51 and this method of threshold analysis is repeated throughout the thesis.

Fig. 96 A-B untraditional architecture, bo both examples have the stage on the left hic revival Churches provide a direct approach from street to sanctuary.

Fig. 97 combines the traditional graphical critiques, these two structures are free standing although allowing no permeability except through the front door.

Fig. 98 the two contemporary structures are integrated into an urban grain leaving one face exposed to the street both of which follow similar pattern of threshold.

Fig. 99 overlays all thresholds examined in this section. The circle overlays locate the central focus of each church (alter/ stage) and its proximity to the street threshold.

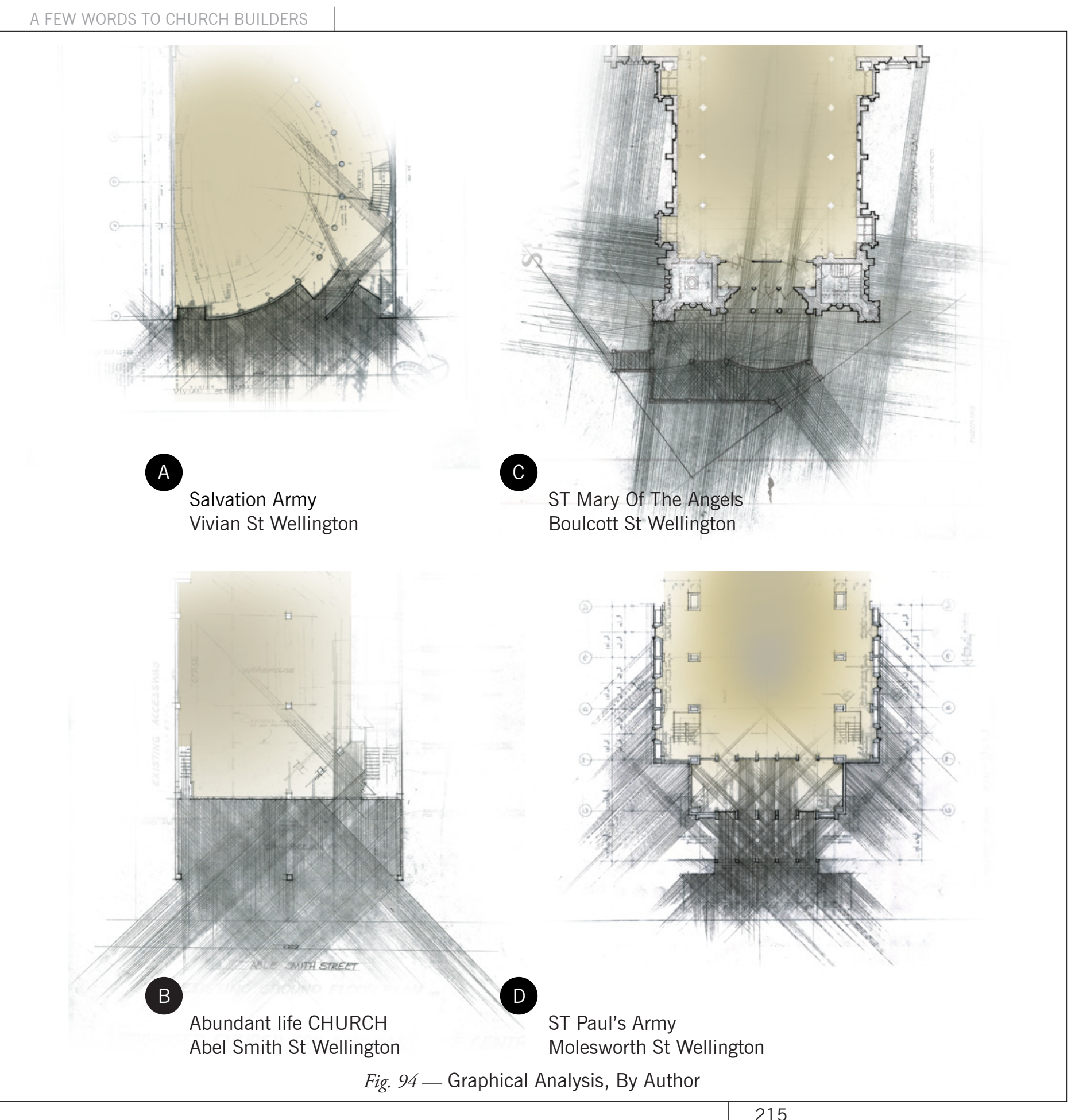



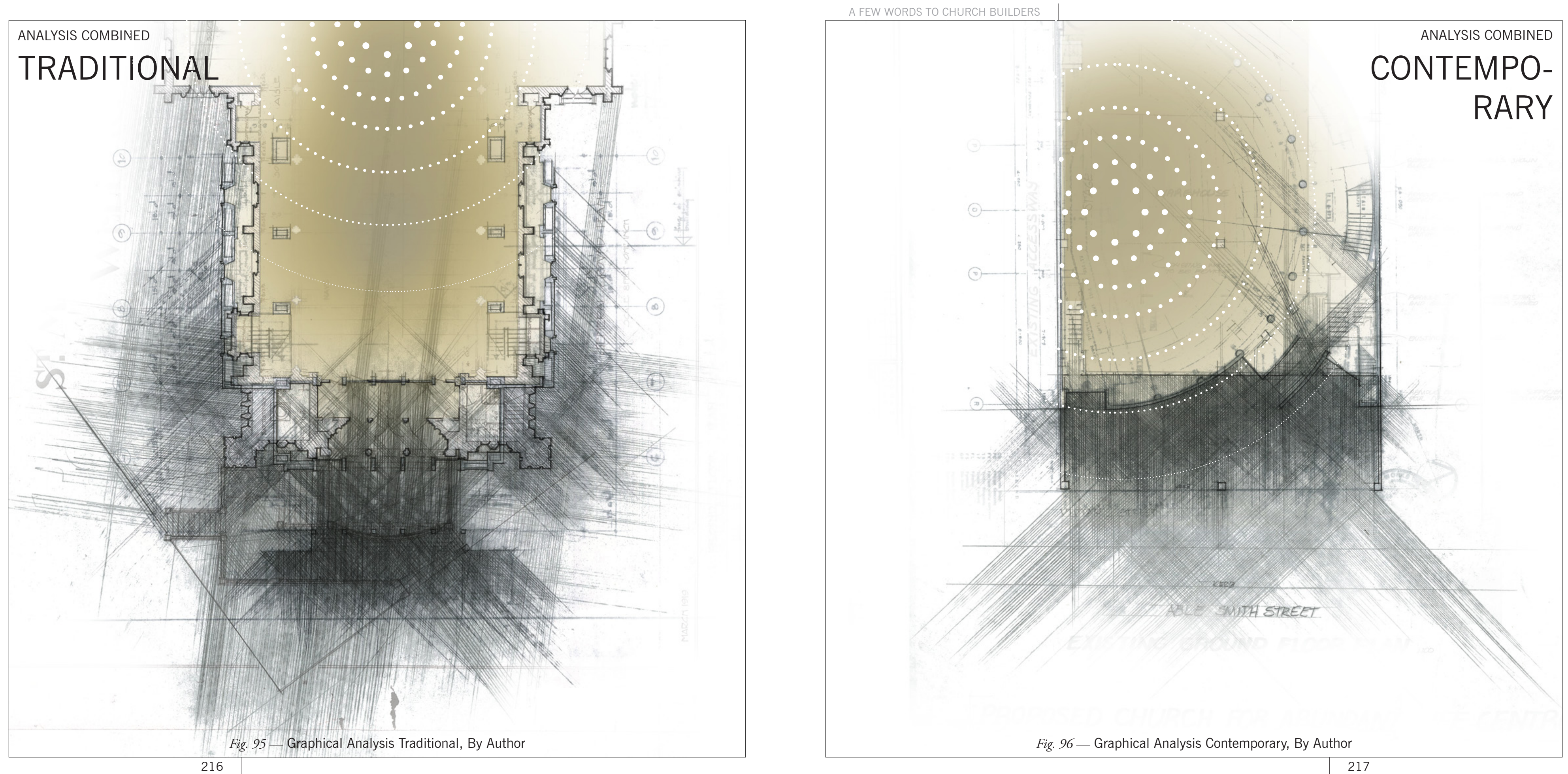


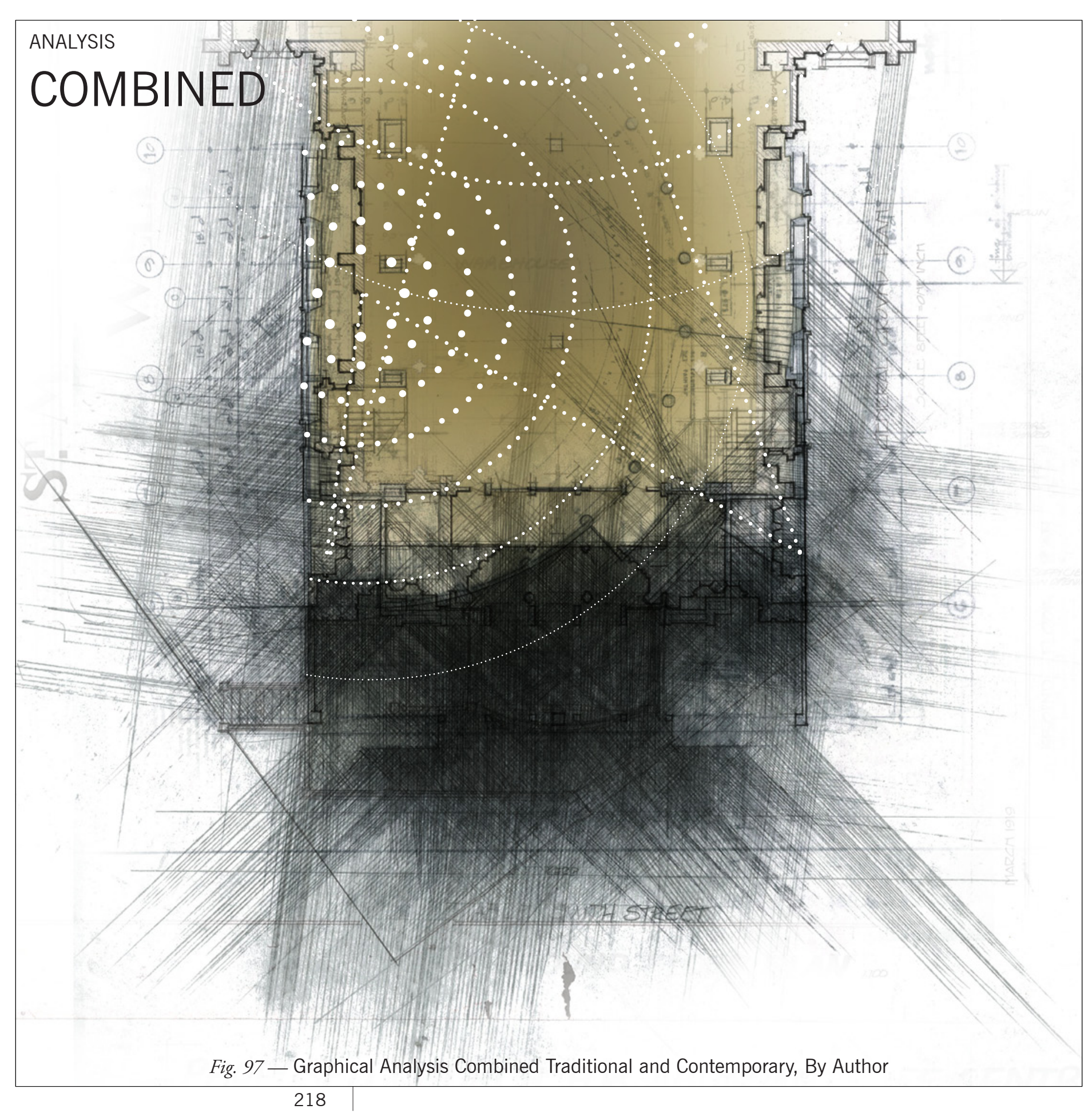

Direct confrontation offered by the

traditional Church layout can be a cause

of discomfort for some people. Spatial

perception can make one feel better

about one's self to come into this space

and meet with God. The sacralisation

of the church allows people to enter

with everyday secular thoughts feeling

and problems; the indirect approach

offers a less confrontation thesoach 


\section{DESIGN \\ ITERATION}

FOUR 
Fig. 98 is the sole image chosen

to represent Iteration Four. The

perspective illustrates the absence of

a strong traditional Church threshold

- which are often sudden and direct.

This threshold blur externalises the

CHURCH; allowing an invitation to,

and an understanding of, liturgical

operation to the passerby. Light

projects from the audissium. Light

projects from the auditorium interior

acting as a welcoming gesture to the

outside world.

It is important to note that this

iteration, along with all the others,

are specific responses to site. Here,

the splaying of form into the public

realm allows space for people to use

in relation to the adjacent park. This

is a purposeful response to the vast

privatisation of waterfront space

privatisation of waterfront space

pacifes the mon Arena. This design

pacites the The soged

in Iteration Thice by untilsing an

invitational form and paring down

architectural flamboyance. 


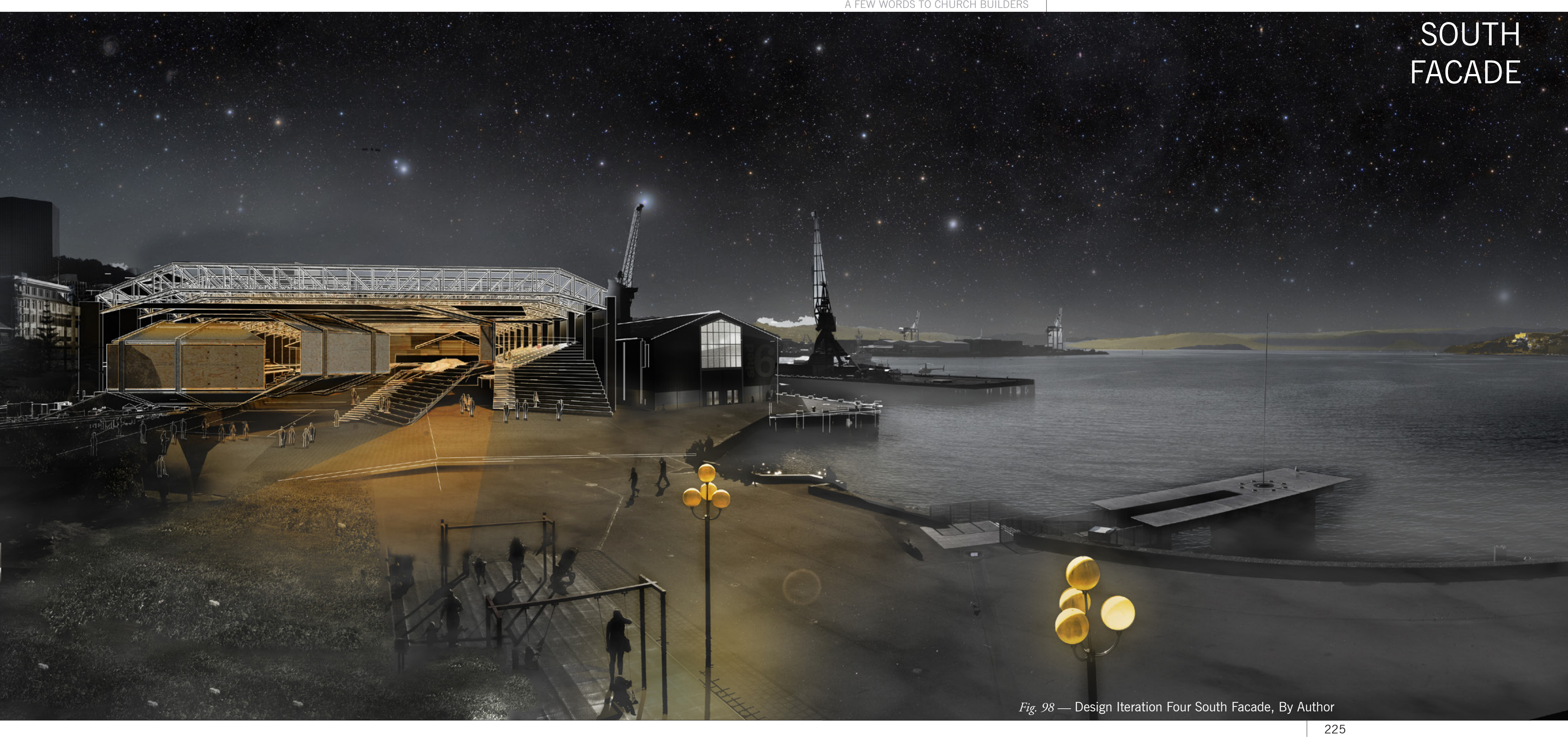




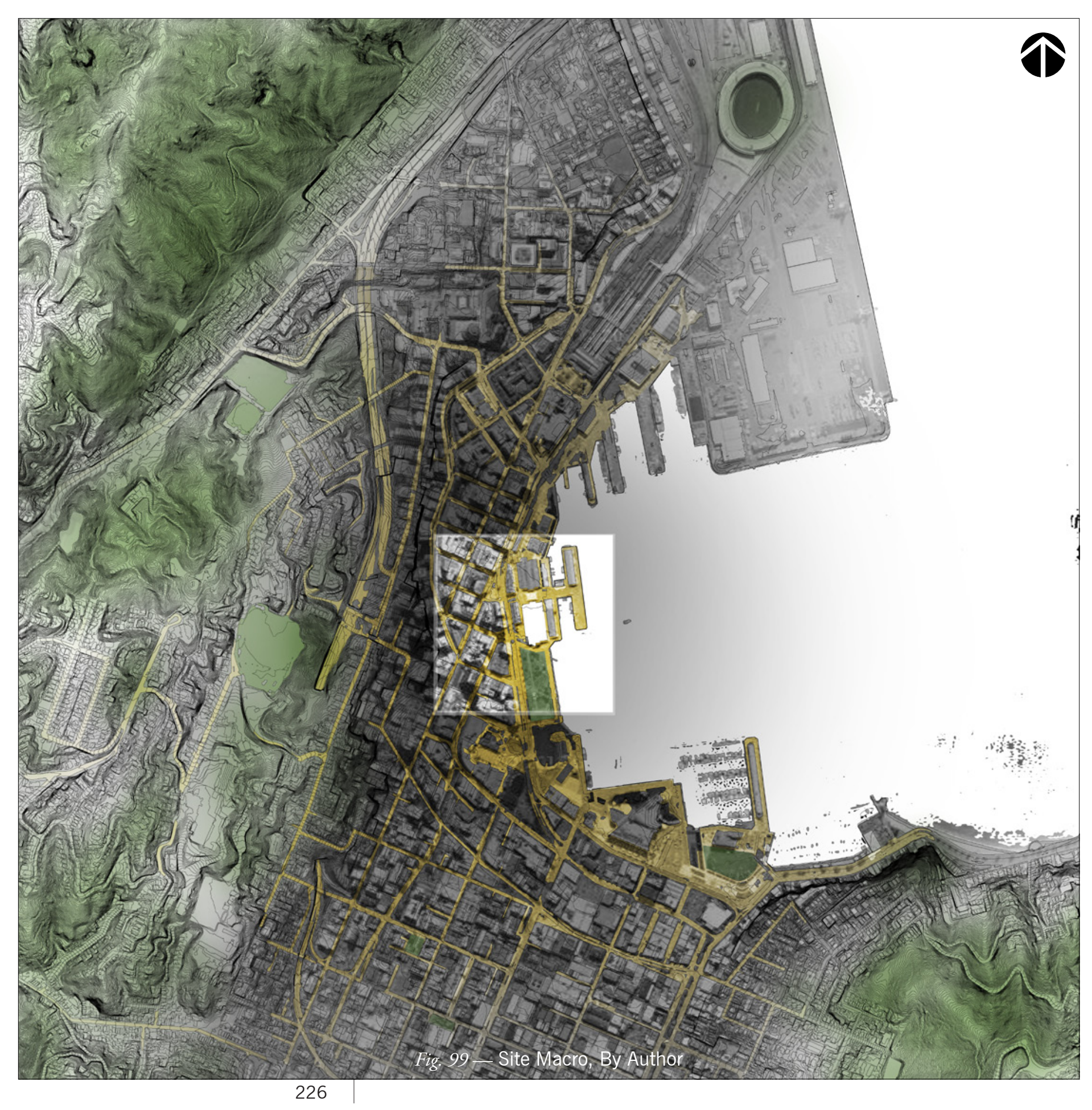

SECULAR INSERTION ANALYSIS 


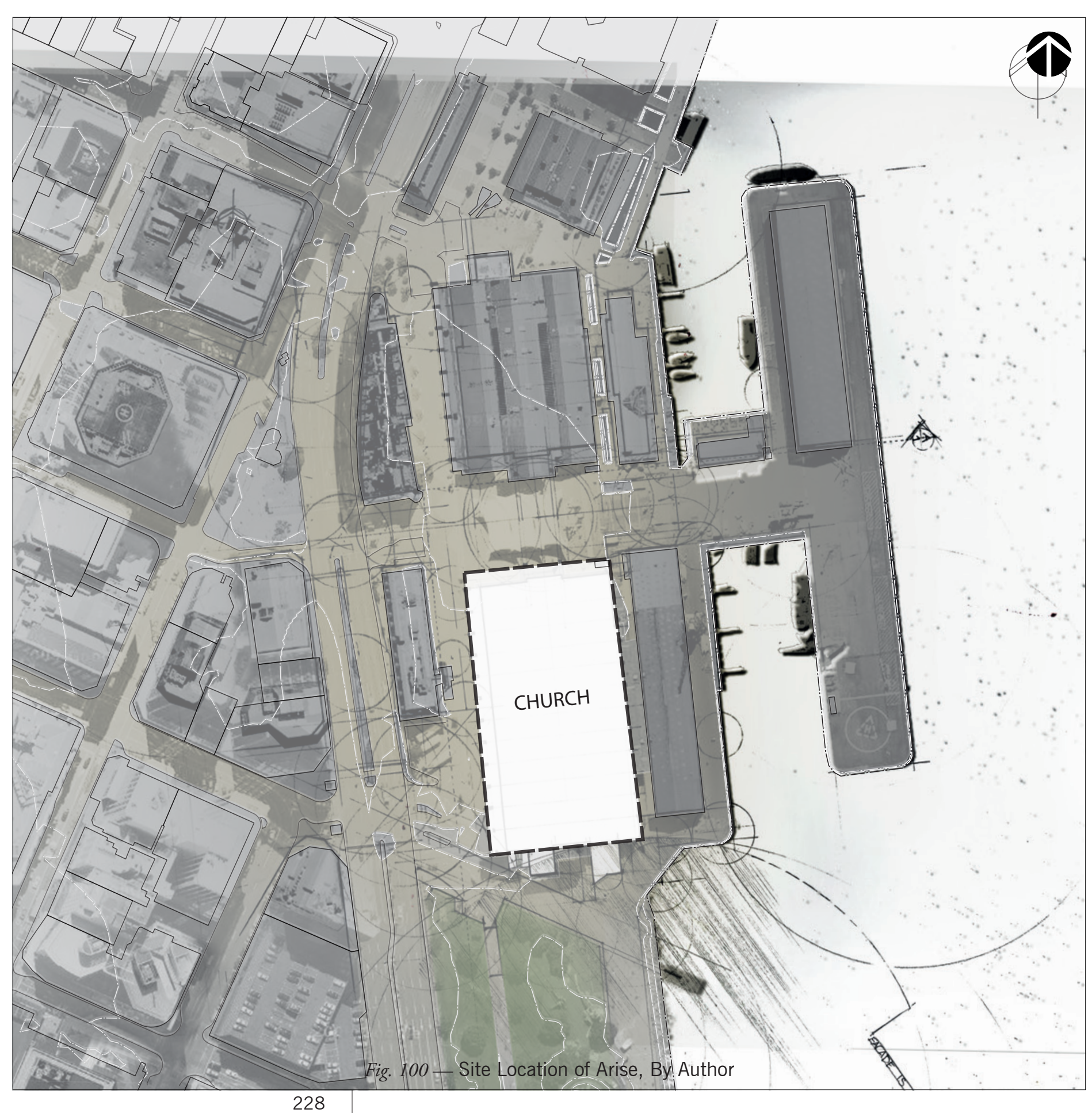

SITE

The TSB arena is a large multipurpose which will provide a visual dialogue for venue situated in the Queens Wharf architecture to refine how the entities precinct on Wellington's waterfront interact or wish to interact. The and home to trade shows, indoor inserted programme will also activate sporting events and concerts. The the site during the week.

building is considered a special activity generator capable of drawing large numbers of people from beyond the

city. Notorious for 'dead space' activity generators generally have a negative influence on their surrounding enve on enver only contribute to activity within the area while in use. Kent A. Robertson in his writing on waterfront stadia identifies 'The difficulty to design such a structure, is integration with the surrounding downtown district.'

The proposed church integration responds to site. The following study teats building and spaces as study teas buldings and spas as netwo ks. Nem ins programme insertion into the Church. The inserted programme will facilitate a coexistence of secular in the sacred,

1. Robertson, Kent A. 1995. pg 434 


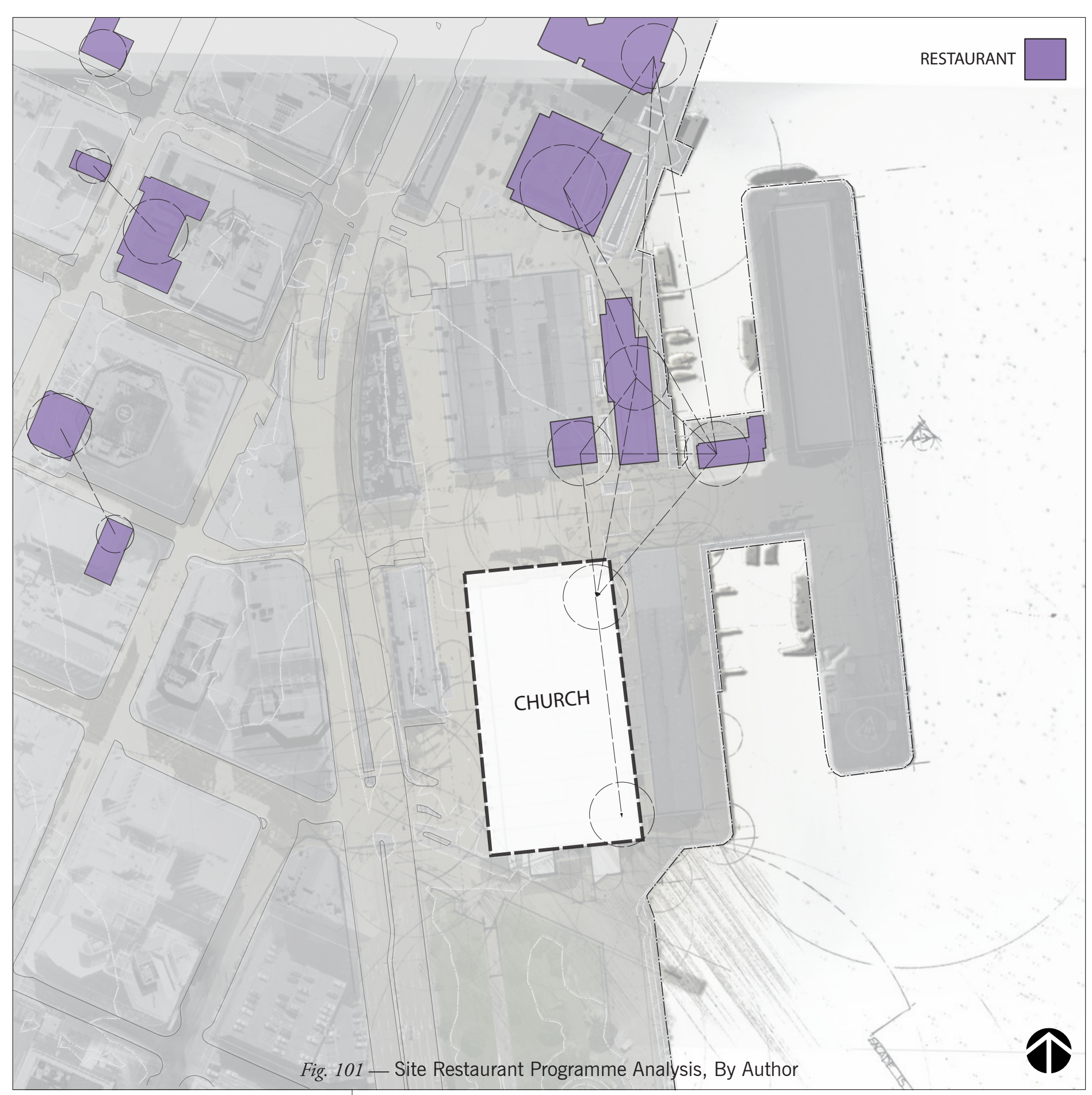

RESTAURANT

The restaurant dining experience is enhanced by proximity to water. Kent A. Robertson in his writing states the sight, sound, and feel of water naturally attracts people, which is why waterfront developments often prosper. ${ }^{1}$ The site's proximity to water lends itself to the inclusion of a restaurant programme, informed by the existing micro clima, informed by the existing micro climate of fine dining north of the site along the waterfron edge. The spill created by the CHURCH service will benefit both the inserted and surrounding restaurants. Through continuing the identified restaurant matrix through the Church by an insertion of programme validates the theological stance requiring a secular inclusion within the sacred. 
The adjacent plan exhibits the existing matrix which informs an art gallery matrix which informs an art gallery
insertion. The network of cultural orientated programmes include a gallery, museum and the New Zealand Academy of Arts. This inclusion of this network taps into another social context affirming their acceptance in the $\mathrm{CHURCH}$ strengthening the sacred secular overlap explained in Theology. 
This analysis informs the insertion of

a brewery into the Church, a response

to historical and social contexts of

site. Wellington's Queens Wharf has a

strong history as a working port. The

industrial programmes which reference

this history include Shed 12's Mojo

Coffee roastery, while further south

sits the now retired Macs brewery.

Wellington's social culture celebrates

We

bouninantly

coffee and bee, incty puch micro

breweries, Parro Dog and Garage

Project. A craft beer brewery as an

inserted secular program will challenge

the Churches architectural acceptance

of such an entity. The presence of beer

is not as important as the architectural

response to such programme. This

construct will be sectionally analysed

in the following chapter Sectional

analysis. 


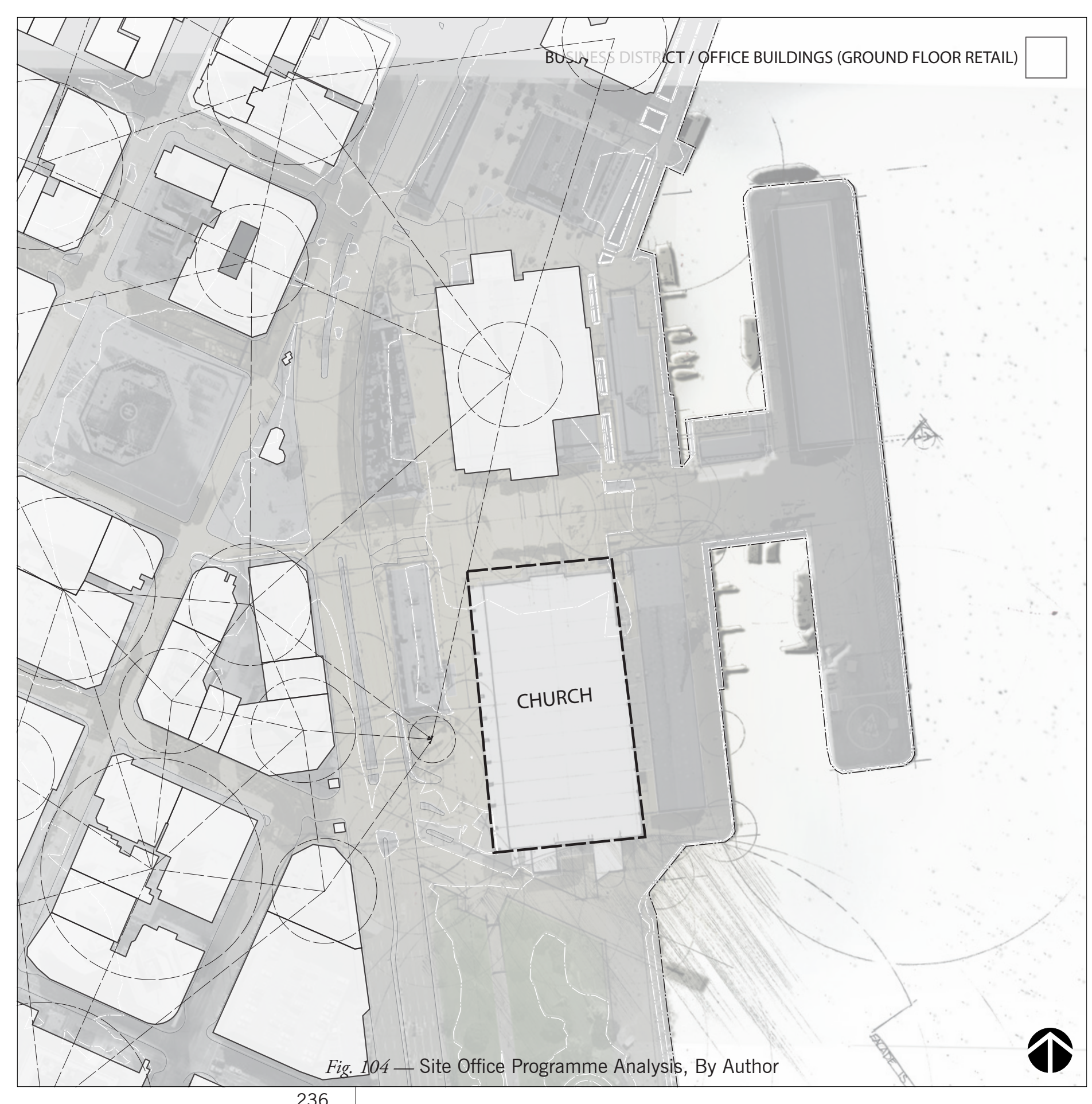

OFFICE

The central business district engages in a complex series of architectural relationships. The elevation and proximity to the waterfront of each structure contributes to its place in the networks hierarchy. The insertion of an office programme into the Church includes the associated network into the sacred/ secular threshold. The existence of such a structure within existence of such a strucure within or about the Chy a building has the potential do develop into a vertical voluth that cold then associate with the notion of the spire. In a previous section titled 'spire,' notions are outlined including a proclamation of power and authority. However the insertion gives an opportunity to architecturally mitigate this discussion secularising the spire.

The following section critiques the sectional and axonometric relationship between the office and Church. 


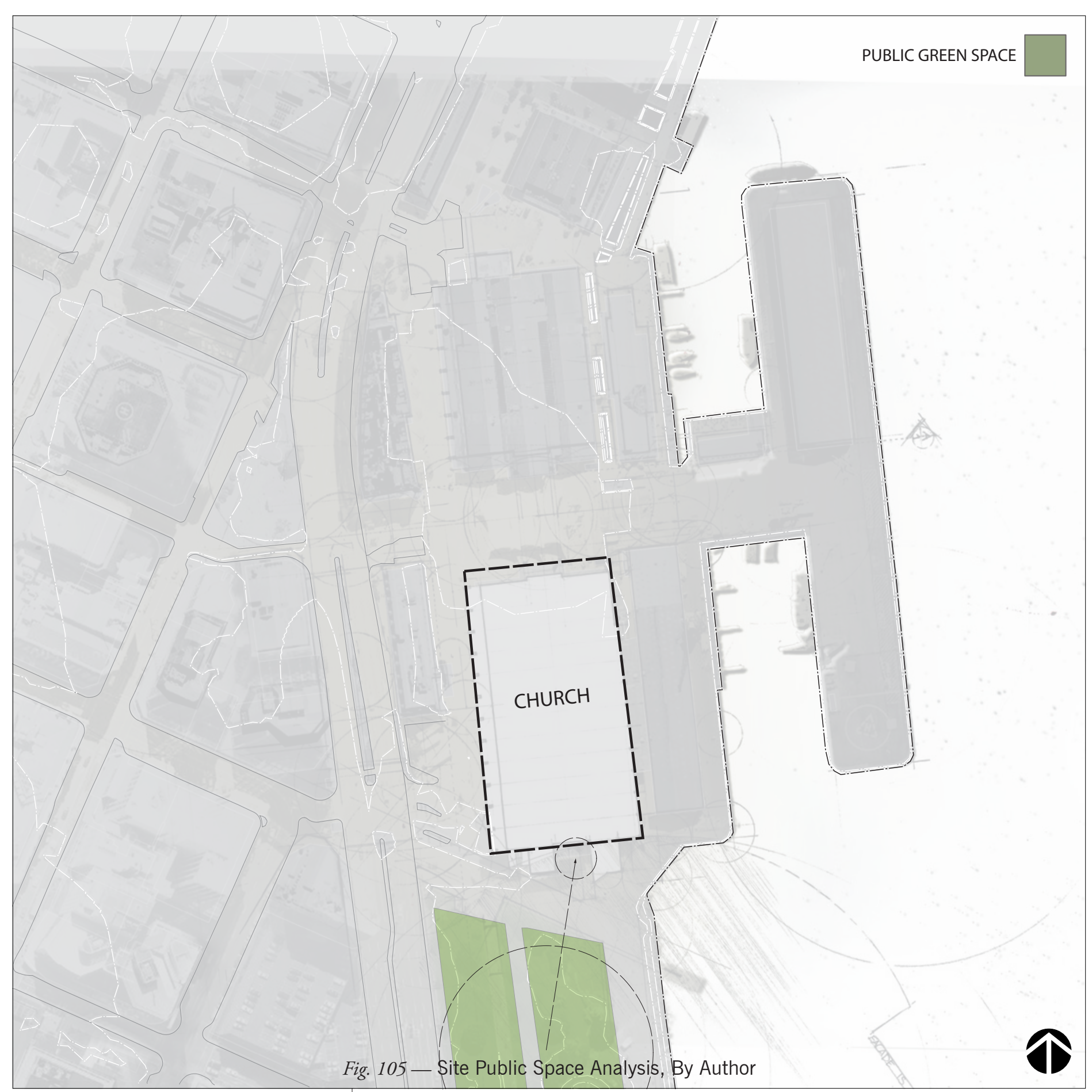

PUBIC SPACE

Open space surrounds the TSB Arena,

this social space, not a static entity, it

is a product of the social environment.

The waterfront is a popular place for

people to relax and spend time. The

book spatial agency warns architects

to be alert of the effect space has on

the lives that use the space. ${ }^{1}$ Inserting

public space into the building forces a

consideration to the way people may

con

The insertion of public space has been

used as a tool to blur the secular and

sacred boundaries in design iteration

four, while iterations two and three

relied upon it.

Final Design intends the public space

to be used as an auditorium extension

placing no limit on event participation.

1. Awan, Schneider and Till. 2011. pg 30 

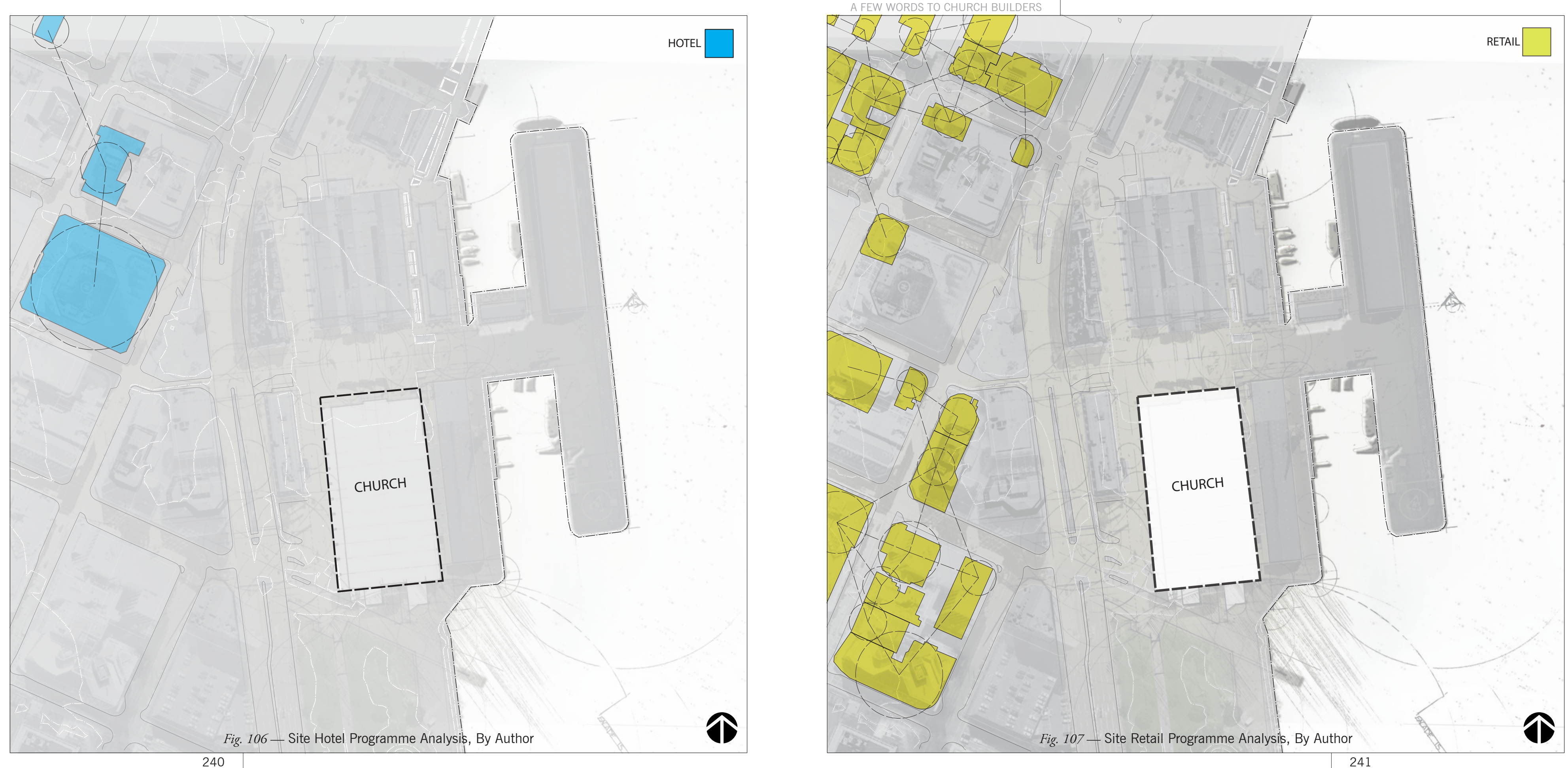
Insertion of secular programme gives

specific context to architecturally

discuss the secular and sacred threshold.

Analysis informs the insertion of gallery, restaurant, brewery and office programme.

Figs. 106-107 informs design not to include retail and hotel programmes include rese networks are distant from the as these networks are distant from the
TSB Arena site.

Fig. 108 identifies the wider selection of programme networks to reference Church insertion. Toyo Ito argued the change of program within a space can blur perceived boundaries. The analysis suggests the coexistence of secular programme and the Church within one structure to blur secular and sacred boundaries. 


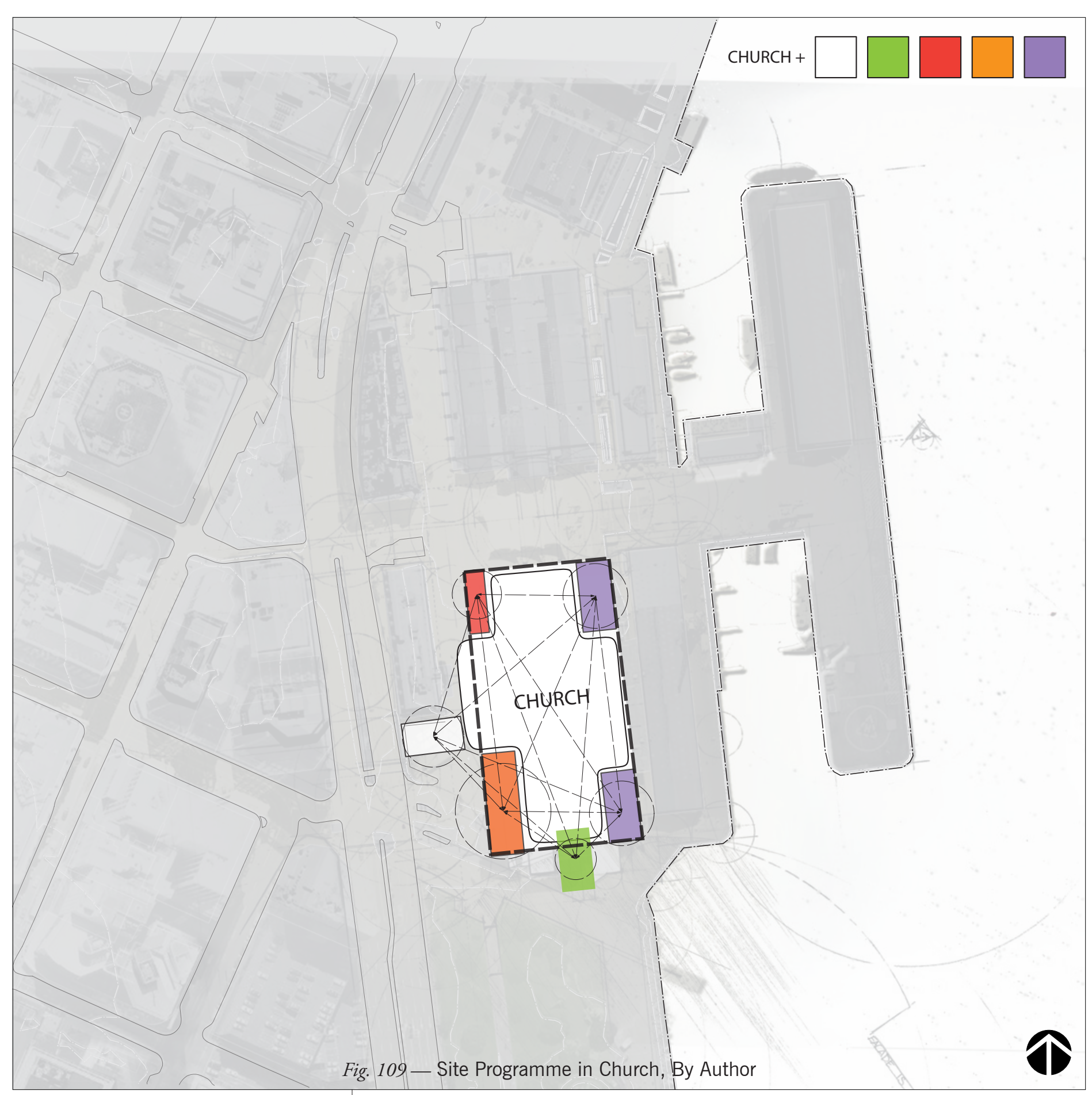

CONCLUSION

Analysis informs the selection of

secular programmes to insert into the

Church's space. Envelope and form

will react to the programmes in a way

that affirms the theological positions

driving design; breaking perceptions

of ARISE CHURCH as a religious entity,

making Church approachable and

receptive to those who pass by Thi

receptive to thill manifest Boyse whis

desire

frite to see the church shift away

More specifically the physical presence

of Church is engaged with the city

beyond Sunday through activation

of the Church through the inserted

secular programme. The coexistence

informs the notion of worship and

God existing in the secular. ${ }^{2}$

Program's interaction with the church wall will be sectionally analysed in Section analysis.

1. Bonhoeffer, Dietrich. 1953. Pg

2. Sovik, Edward. 1973. pg 37 


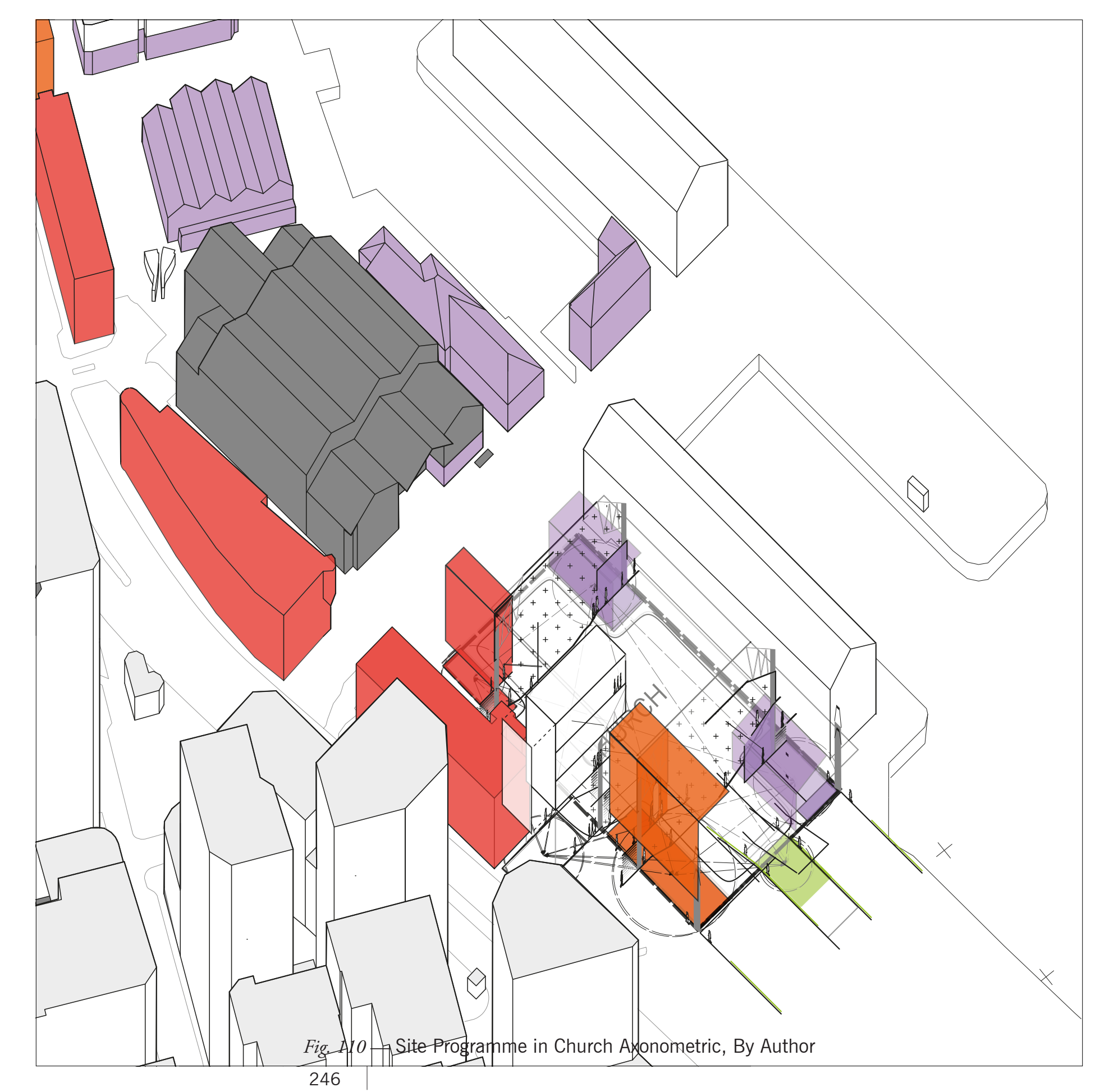

SECTIONAL ANALYSIS 
This section develops upon the Sovik who outlines the 'non-Church' insertion of a secular programme (influential to this thesis) states: into the Church, critiqued through a 'Encounter takes place, not because matrix of sectional relationships. The men leave their ordinary lives and following investigation critiques the proceed to a different place where God way in which the sacred and secular is, but because God enters their world entities could interplay. It is critical and their lives where they are."2 The to resolve the way the architecture envelope will release an Efflux from facilitates and reflects the CHURCHES the Church to the secular programme; portraying God in the brewery theological standpoint. portraying God in the brewery,

Contradictory to the investigations intent are the regulations Carlo Barromeo puts forward in his book,

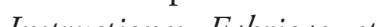
Instructiones Fabricae et Supellectillis Ecclesiasticar: "Interference caused
by noise from outside or by profane by noise from outside or by profane activity should be avoided, hence a standing and separated by a few paces from other buildings." Barromeo outlines a separation between the outlines a sepildins. Bart n affirm the previously sact the position, design intends an overlapping and interplay between the two

Tschumi simplifies buildings down to vectors and envelopes, his theories inform the investigation. The interplay surrounding envelopes is here explored specific to each programme. The investigation is laid out in a table, which acknowledges different sectional relationships, each reponding to established positions. To between postions. The envelope this catons "an be relationships of indifference, 1. Barromeo Carlo,

. Sovik, Edward. 1973. pg 36

analysis sets up a framework in

which the response to stance can be

critiqued through various possibilities;

overlapping, mingling, ignoring,

looking etc. 
The sectional matrix seen in Figure water, secondly attentive toward the 113 relates to Tschumi's discussion stage within the worship space. This is on envelopes and vectors. In order to informed by the convoluted sectional critique ways in which the restaurant relationships seen in Design phase five. and $\mathrm{CHURCH}$ entities could interact,

looking, observing, indifference,

conflict etc. ${ }^{1}$

Vectors refer to 'peoples movement within a space, ${ }^{2}$ In this project the proximity to water informs a dining experience with focus towards the water rather than the Church. As the restaurant programme is focused towards the water, enhancing the dining experience, the Church is

focused toward the secular. Different

relationships are highlighted in the table

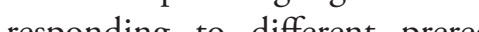

responding to diferent prequisite

contighted seciona highlighted sectional relationships are developed into axonometric in Figs $116-118$

Design phase six uses changing sectional relationships, first attentive toward the

1. Tschumi and Cheng. 2003.pg 64

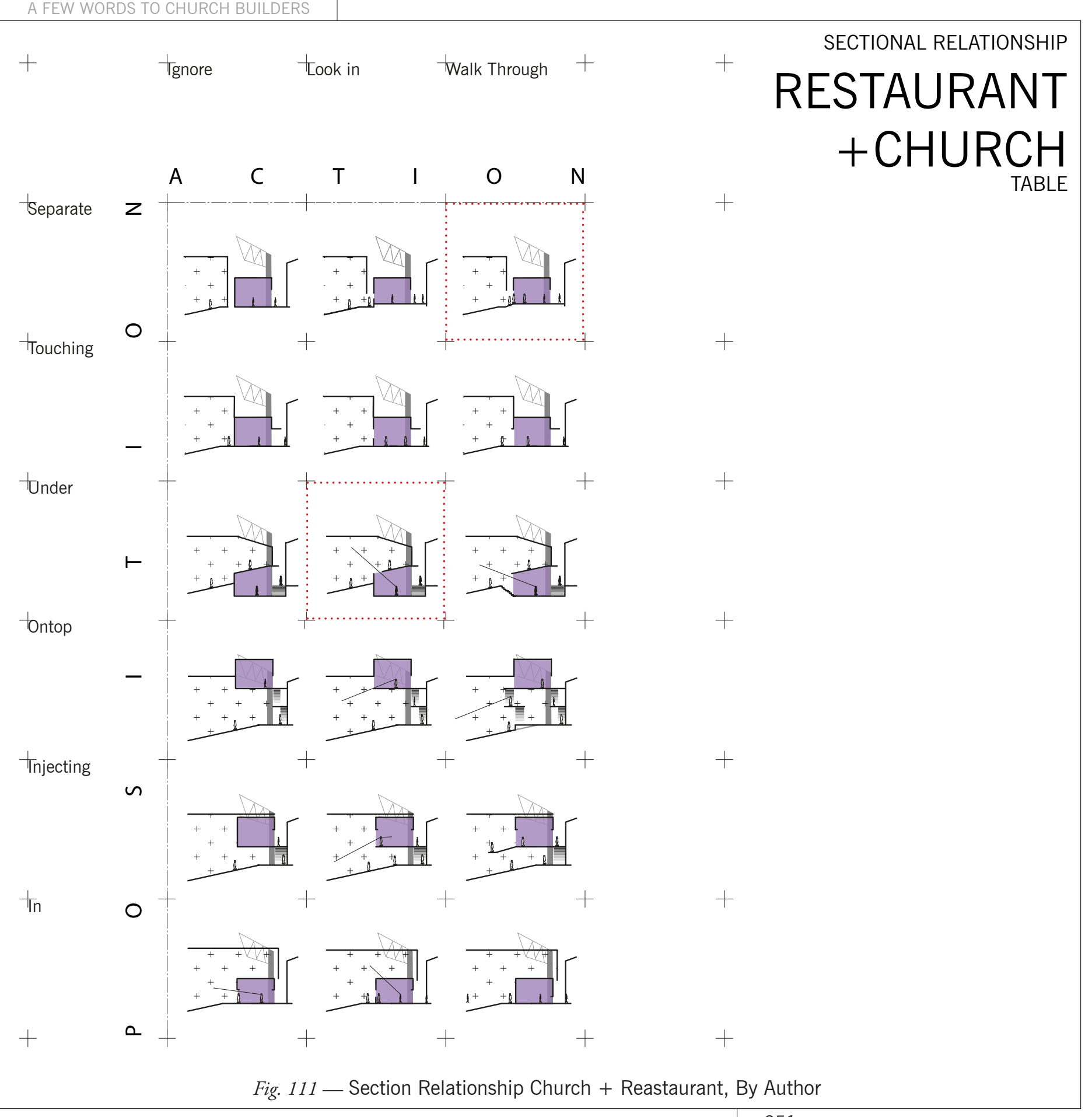


light qualities. The sectional critique

highlighted suggests a subtle inclusion

of CHURCH; a relief or a indirect

glimpse. While the programme of

an art gallery is injected into the

Church it is accessed from outside.

This relationship along with the other

selected sectional relationships will be

combined into axonometric. 

The insertion of beer is intended to the line between public and private to
raise questions of acceptance. Having no longer coincide with the outer limit a stance only on love, (to love as Jesus of a building. ${ }^{2}$ This is an architectural has loved us) the CHURCH theology motif that could be applies to the informs all entities must be accepted. secular and sacred discussion.

The importance within this discussion

lies with the difference between

acceptance and approval. 'It is not

the CHurcli's role to be judge and

jury' according to Cal Lenz pastor

f Hillsong New Yok Ciryt He sto

"The cilno

"The cinunci's only job is to accept."

The architectur's role in this discussion

is to ensue a dialogue of acceptance on

The highlighted diagram offers an unforced relationship. The insertion of the Brewery into the Church wall removes distinction between programmes. This closely aligns to what Beatriz Colomina mentions on skinless architecture, written in Tschumi's book; The State of Architecture at the Beginning of the 21st Century. Colomina outlined an architecture that enabled 
Pubic space is a question of both slope toward the church facilitating an urbanism and architecture. The outdoor auditorium.

TSB Arena is currently ignorant and

uninvolved with the adjacent park.

This sectional analysis suggests ways

the architecture can respond to public

space.

Wolf Prix describes Coop Himmelbaus UFA Cinema Centre as a project that attempts to create public space through architecture; "The model of the building as object is replaced by the idea of urban transistor-an architecture that is capable of amplifying the urban spaces adjoining.' ${ }^{.}$Prix describes the urban qualities of the site attribute to a copened up TSB will allow view TSB will allow view and interaction of programme and form with socia space, reminiscent of previous design investigations while the sites reaction to the building will create a gentle

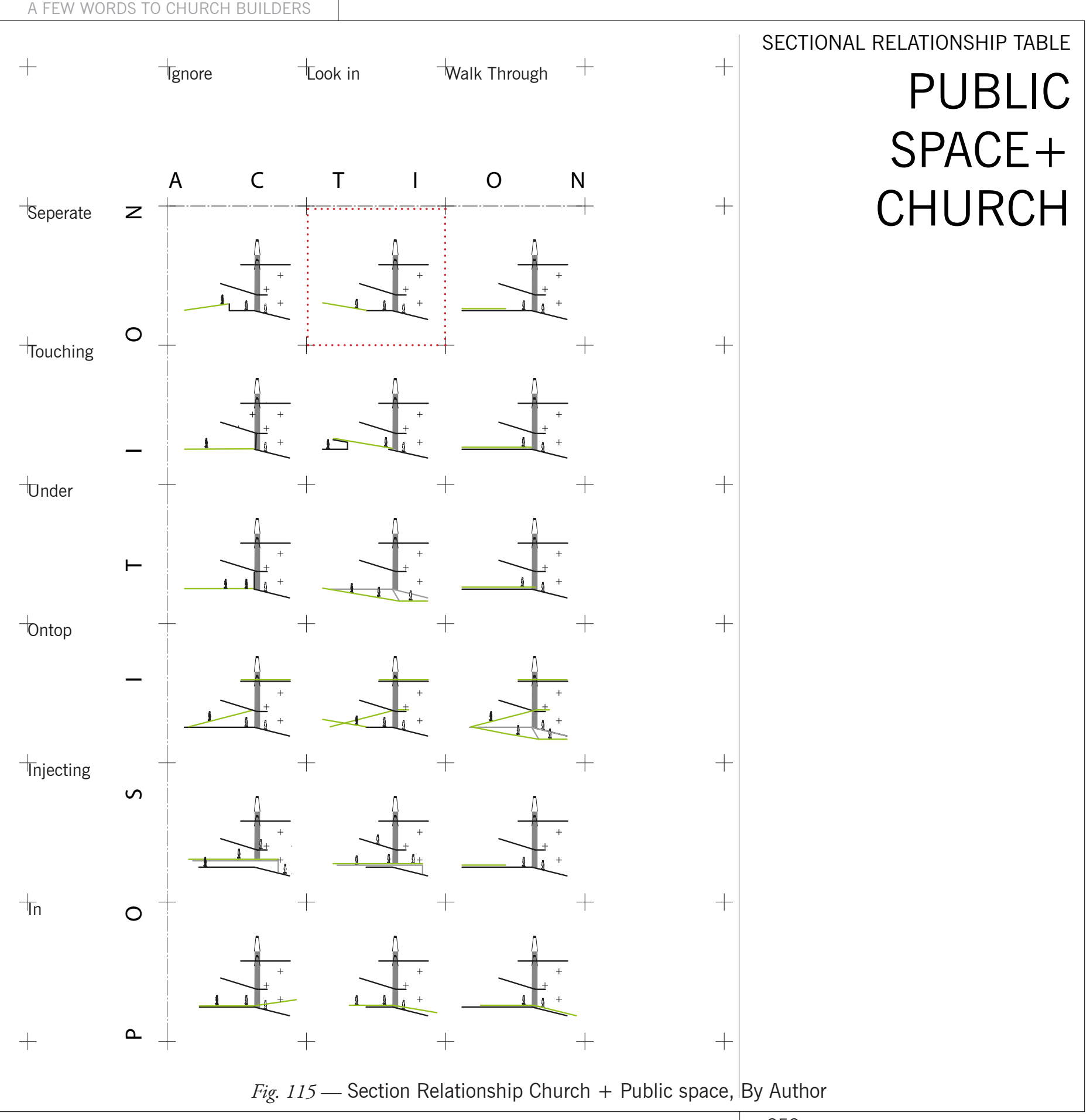



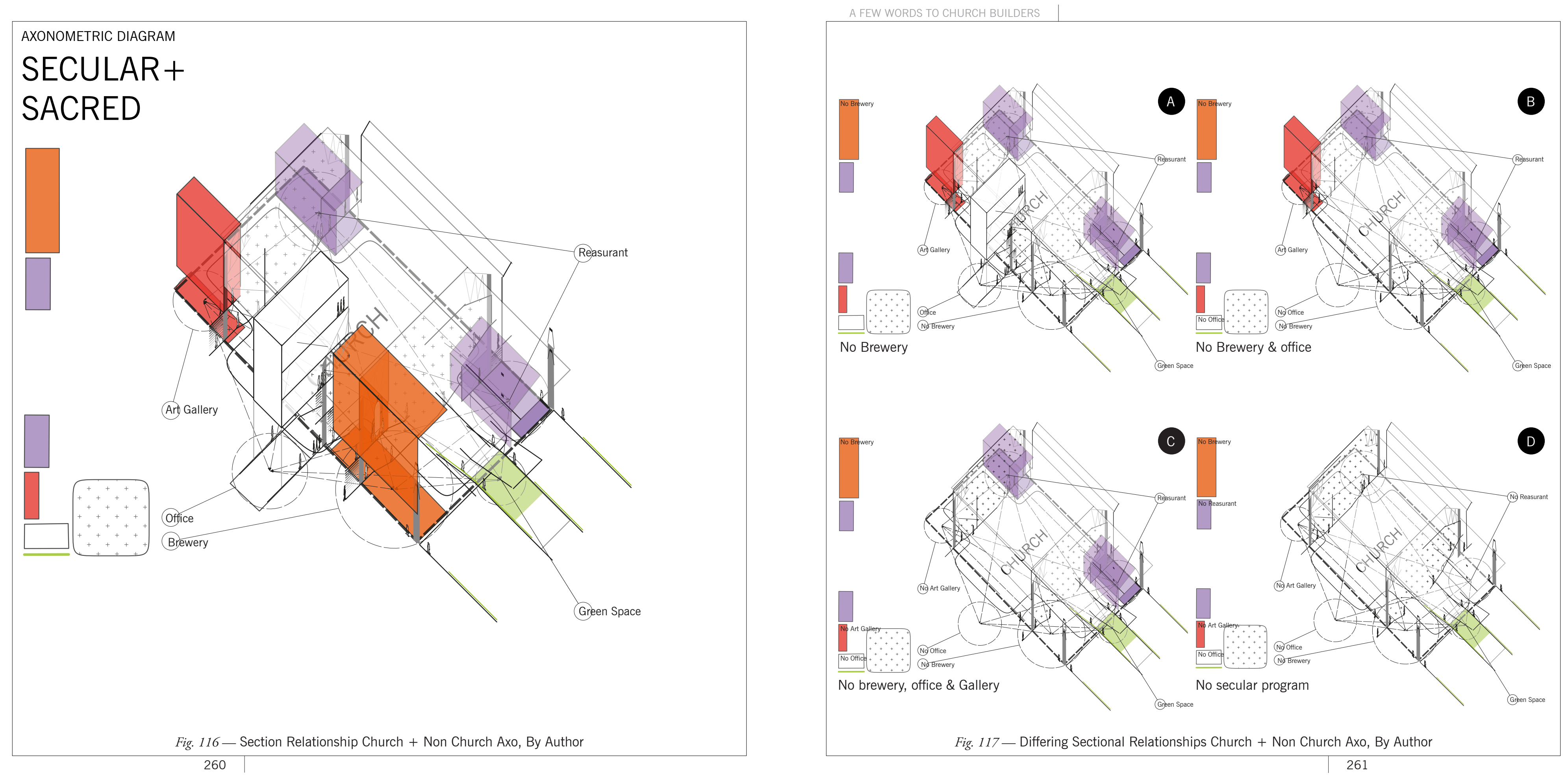
Church structures should not be built unless they are directed to the service of the community of people around them and become a means for the Christian community to provide as effectively as possible not only for its own need, but the needs of the community.' $E$ A Sovik, Architecture for worship.

Inserting secular programmes will as monument. The programme overlap the secular (non-church) with offers little to the sacred and secular the sacred (CHURCH). The relationship discussion of threshold.

outlined represents and facilitates the

CHURCHES outward focus. Figures 118- Fig. 118 questions the multiple

120 develop the extracted relationships program within a single entity as mall

from the previous sectional analysis in like, informing the allowance of space

axonometric. The developed enclosures rather than ownership.

react with the Church according to

their corresponding section diagram.

Temporal insertion of the secular dilutes the threshold overlap, not expressing Fig. 116 combines all programmes
and their corresponding sectional theological concept; 'God in all
of life.' The architectural engagement and their corresponding sectional $\begin{aligned} & \text { of life. The architectural engagement } \\ & \text { of these secular programme and their }\end{aligned}$
relationships. 117 interplay with the sacred drives Design

of each entity. The office prog or failure

of each entity. The

has been questioned throughout the

insertion analysis, critique informs its

is removal due to visul engrement

1. Sovik, Edward. 1973. pg 39

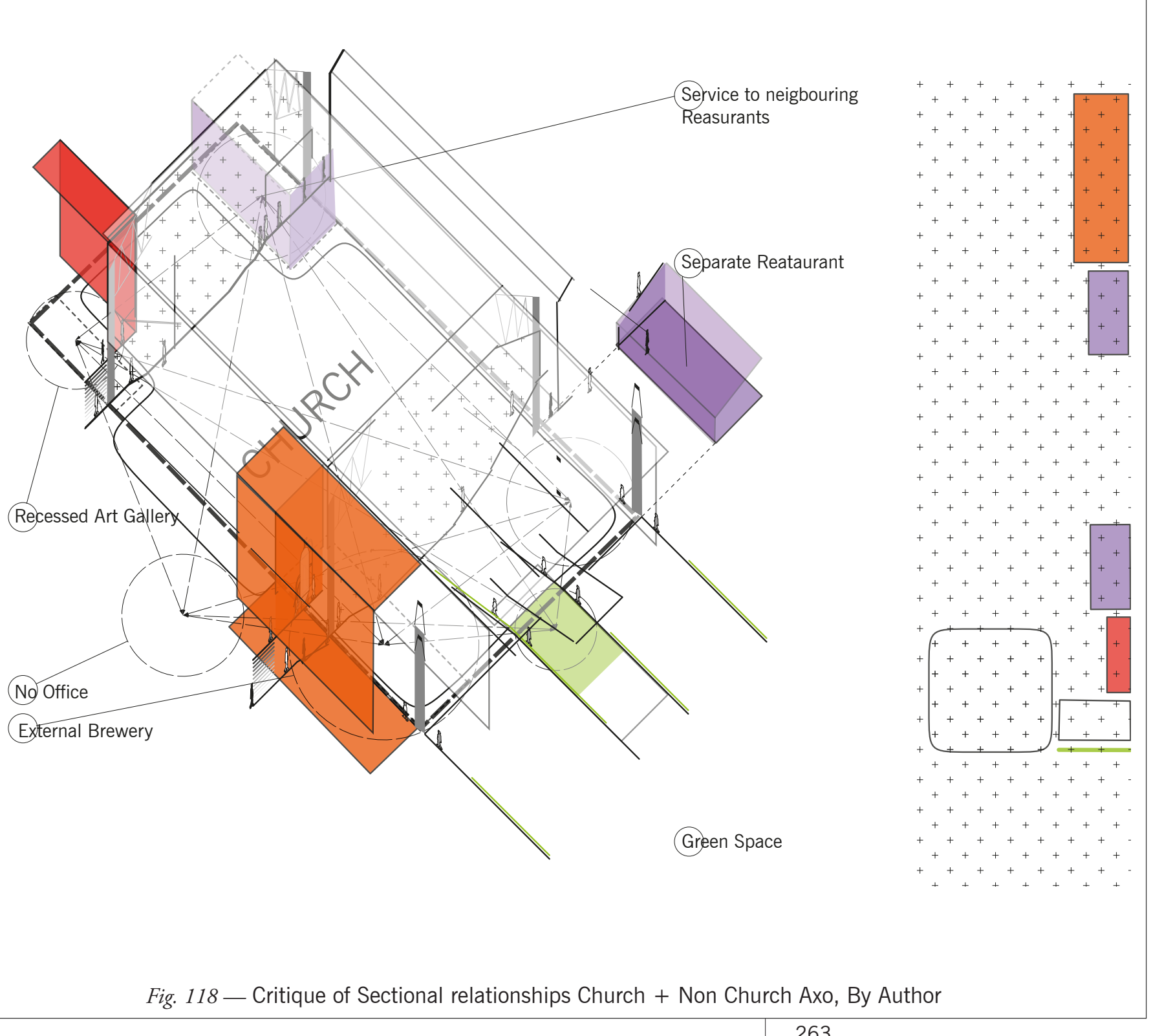




\section{DESIGN \\ ITERATION \\ FIVE}


Form and envelope, the discussion of Fig. 120 illustrates in plan the iterations one to four is combined with auditorium layout and secular the insertion of secular programme. insertions (Blue). The apparent Through the application of these modular grid is broken by the devices design iteration five dissolves auditorium responding to the stage. the church envelope and perceptions The Brewery encroaches immediately of secular and sacred ownership. The upon the stage, while the restaurant Church is made receptive towards spaces are withdrawn into the foyer people who pass by

Fig. 119 illustrates form responding to the adjacent park. Operating within the existing structural frame the southern end of the Church houses the brewery and restaurant. The secular programmes follow the same architectonics as the church; operating within the bounds of a repeating module and material palette. The fragmented facade breaks down notions of solidity and enclosure creating a visual and physical coecting a visual and physical connection between the interior space under the auditoria balcony. The plan annotates three differing the worship space
the from the park to Entrance condition one also viewed
through section B in fig. 128, dives under a low auditorium balcony bay, in a direct low approach of the stage.

Entrance condition two climbs stairs before descending down into the auditorium.

Entrance condition three on ground level takes people through the foyer under the auditorium balcony into the auditorium. space under the auditoria balcony.
Fig. 121 illustrates the interior condition of the art gallery, which established in the sectional analysis, allows a relief in the wall allowing light from the auditorium to pollute the gallery space.

Fig. 122 shows the envelope dividing the Church auditorium and brewery. The brewery is subject to atmospery. conditions from the Church. The envelope allows light and sound to envelope allows light and
travel between the two spaces.

Fig. 123 illustrates the interior conditions of the auditorium absent of theatrical lighting. The space is subject to a large amount of natural light. A visual connection between the inside out can be comforting to people unfamiliar with the church environment. The balcony and ground floor auditorium spaces are separated to allow the direct involvement of the to allow the direct invol
Fig. 124 in comparison shows the existing interior condition of the TSB Arena; no exterior of foyer involvement.

Fig. 125 in section describes the integration of the brewery with the Church. The relationship in section appears oppressive, pressing down This viry and using it as structure. established theological positions.

Fig. 126 illustrates entrance condition one.

Fig. 127 explores the threshold through the opposing access, of which allows little to no interaction. Design appears to be a slave to the module it follows.

Fig. 128 details the structural make up of the envelope. The layering of wood
and glass blurs a semi transparent envelope. 
(1) xtin 政

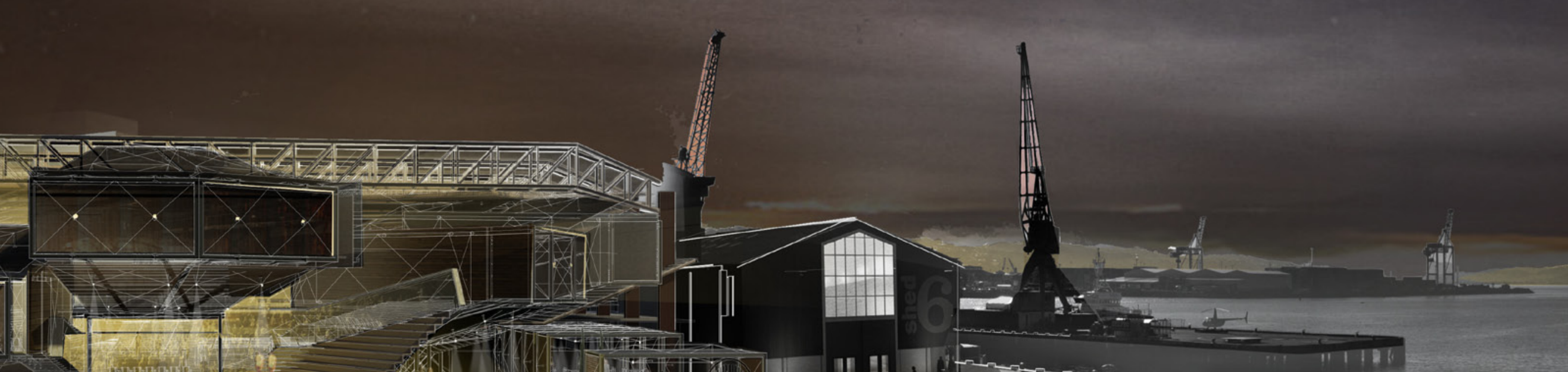
Dind
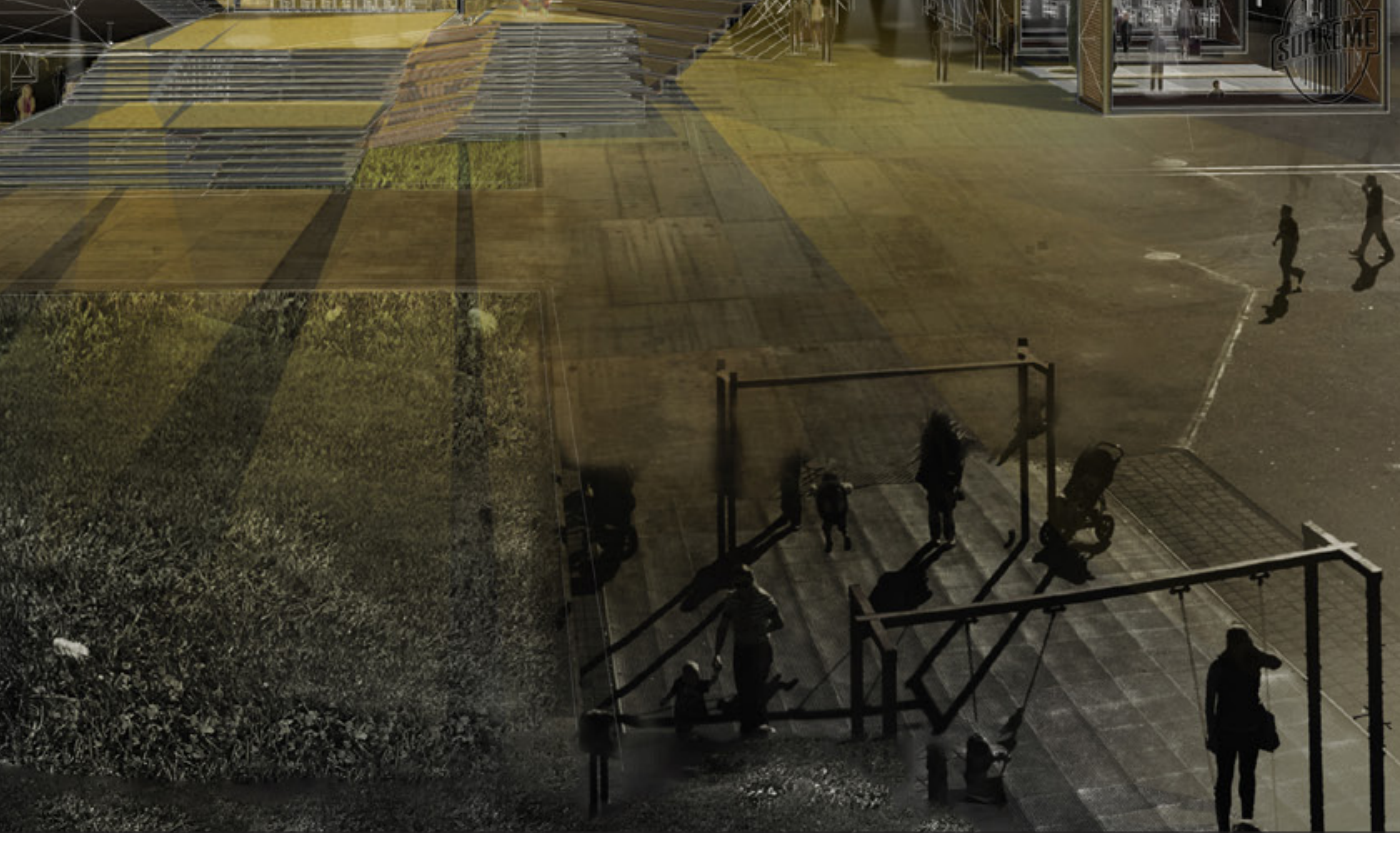

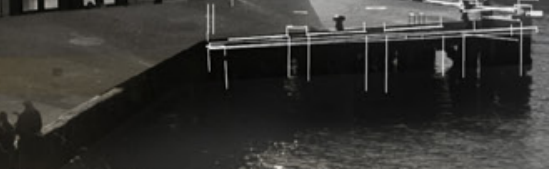
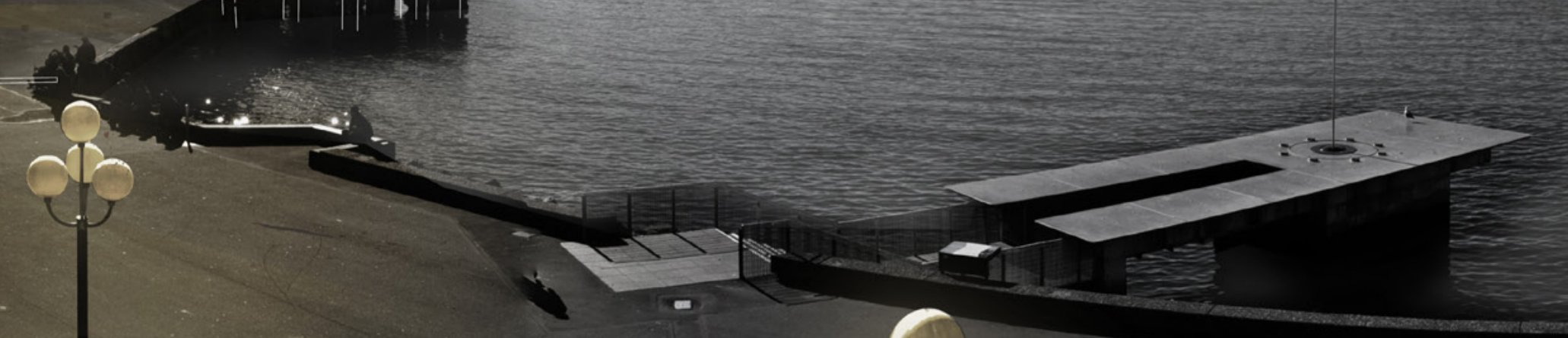
ENTRANCE CONDITION
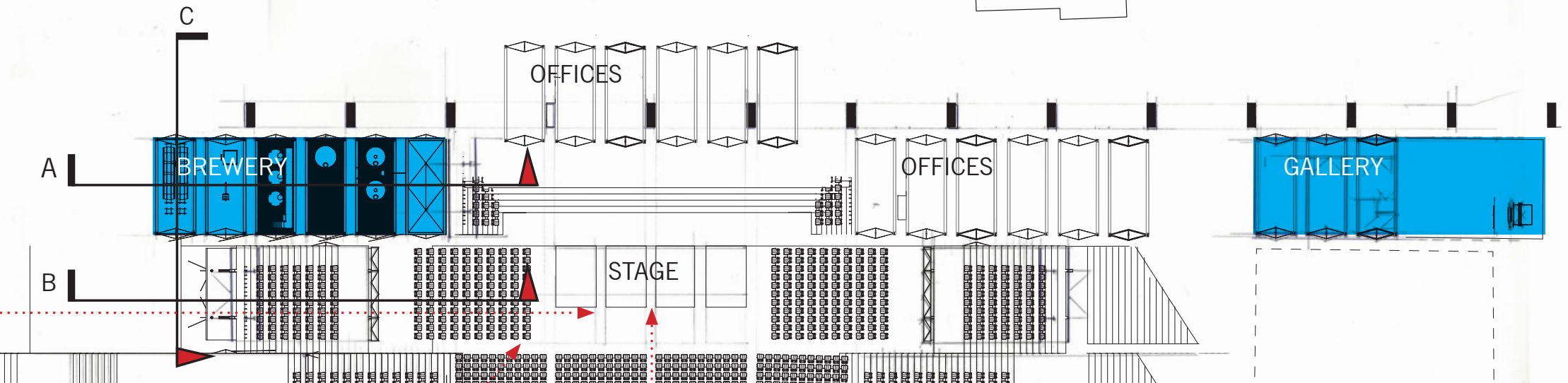

ENTRANCE CONDITION 2

FRANK KITS PARK

ENTRANCE CONDITION 3
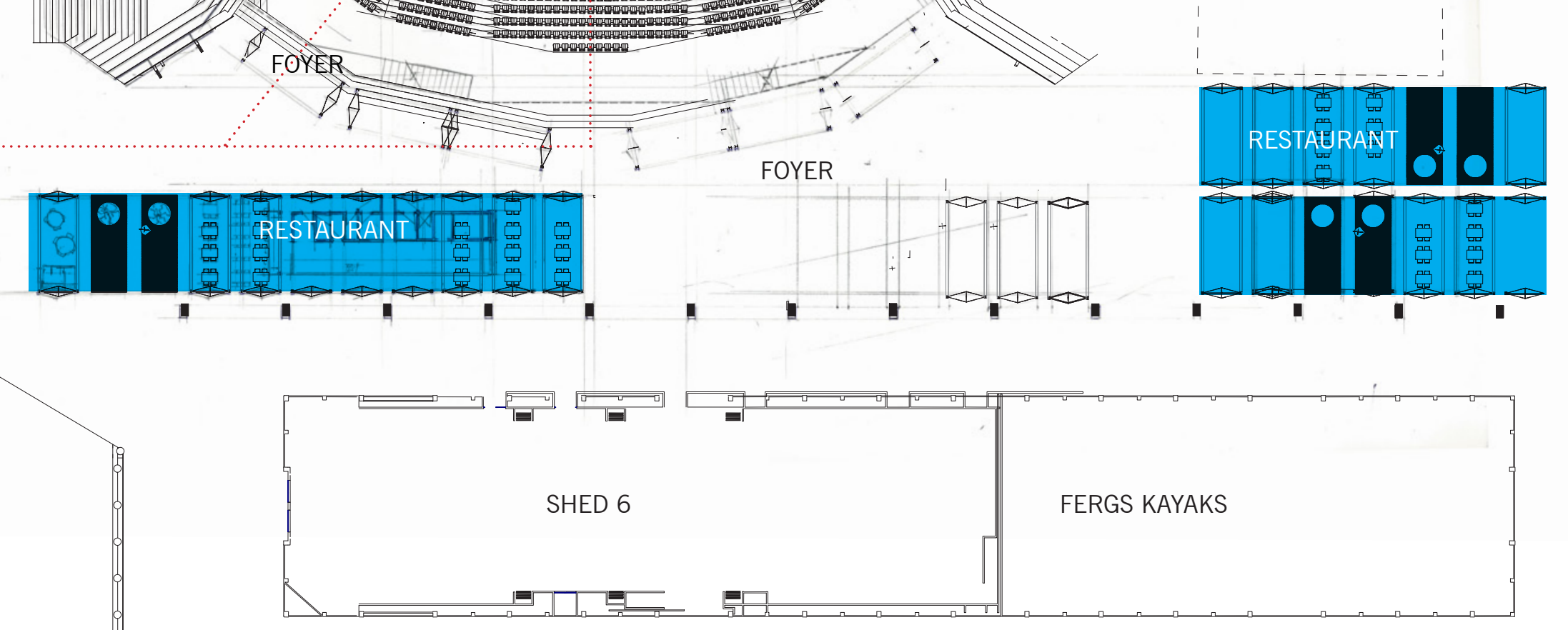

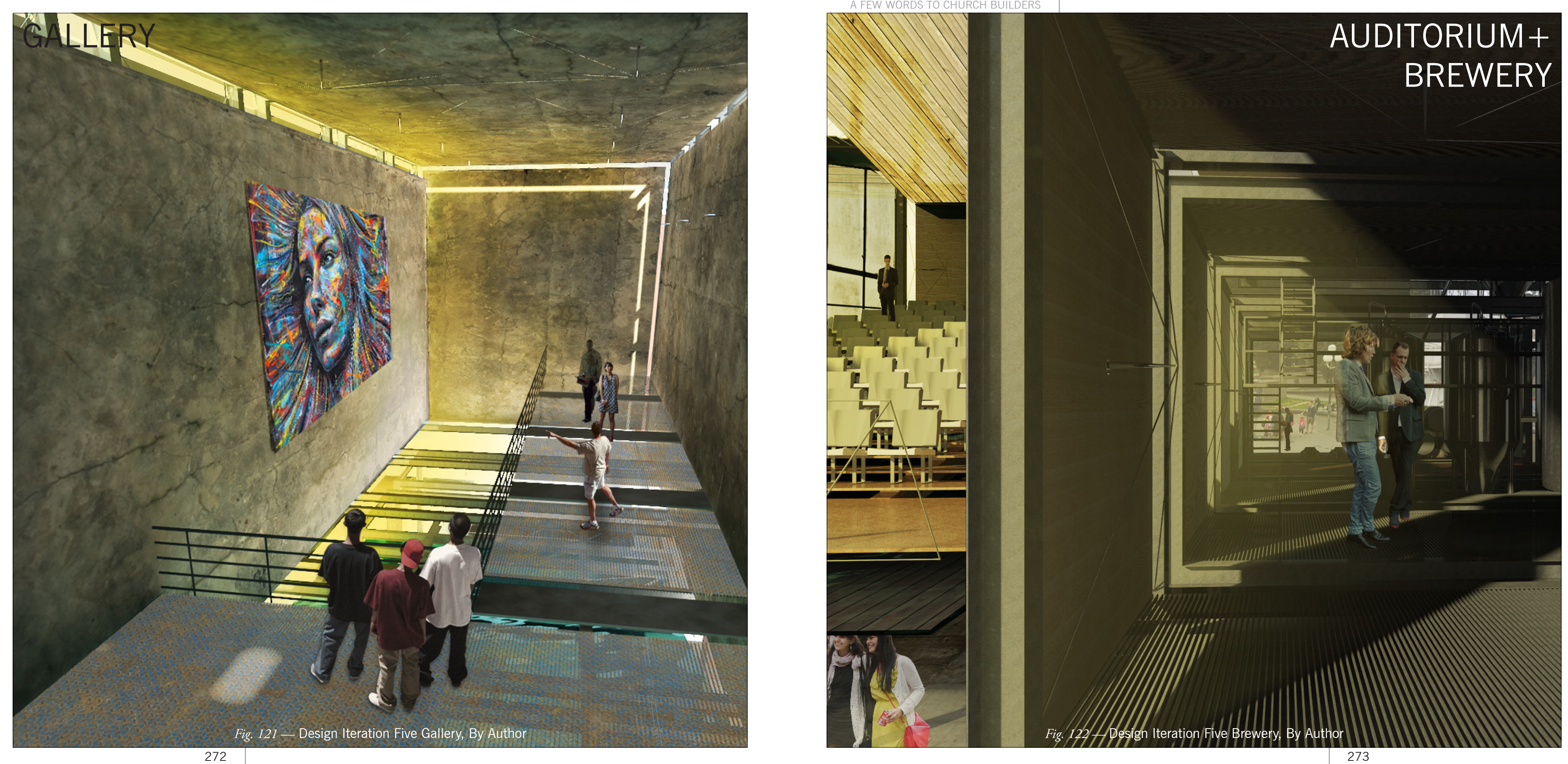


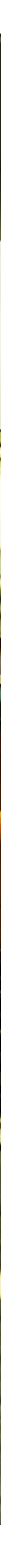




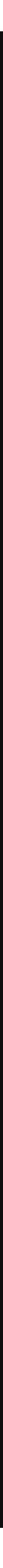




\section{SECTION A}

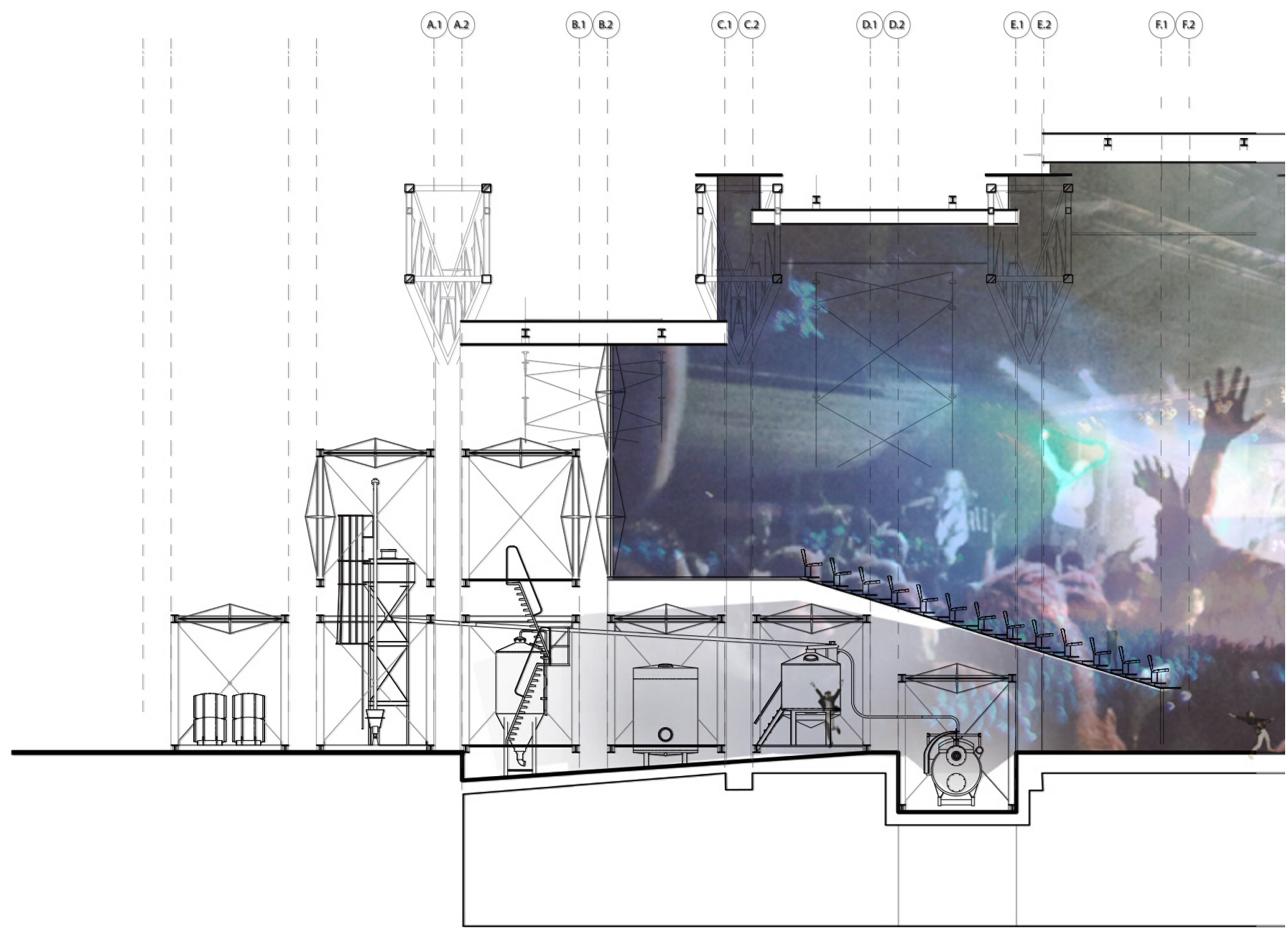

Fig. 125 - Design Iteration Five Brewery Auditorium Section, By Author 278

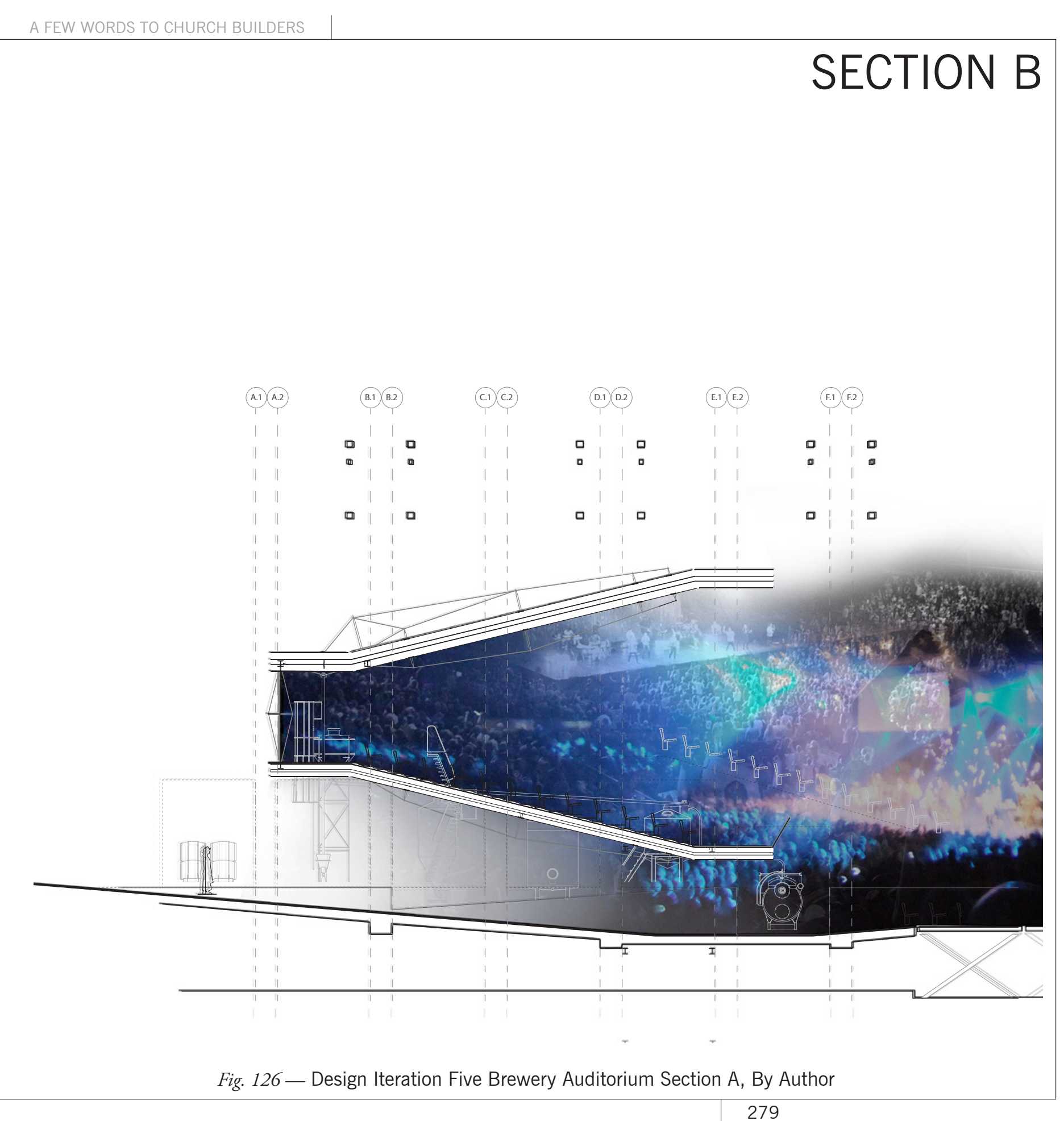




\section{SECTION C}

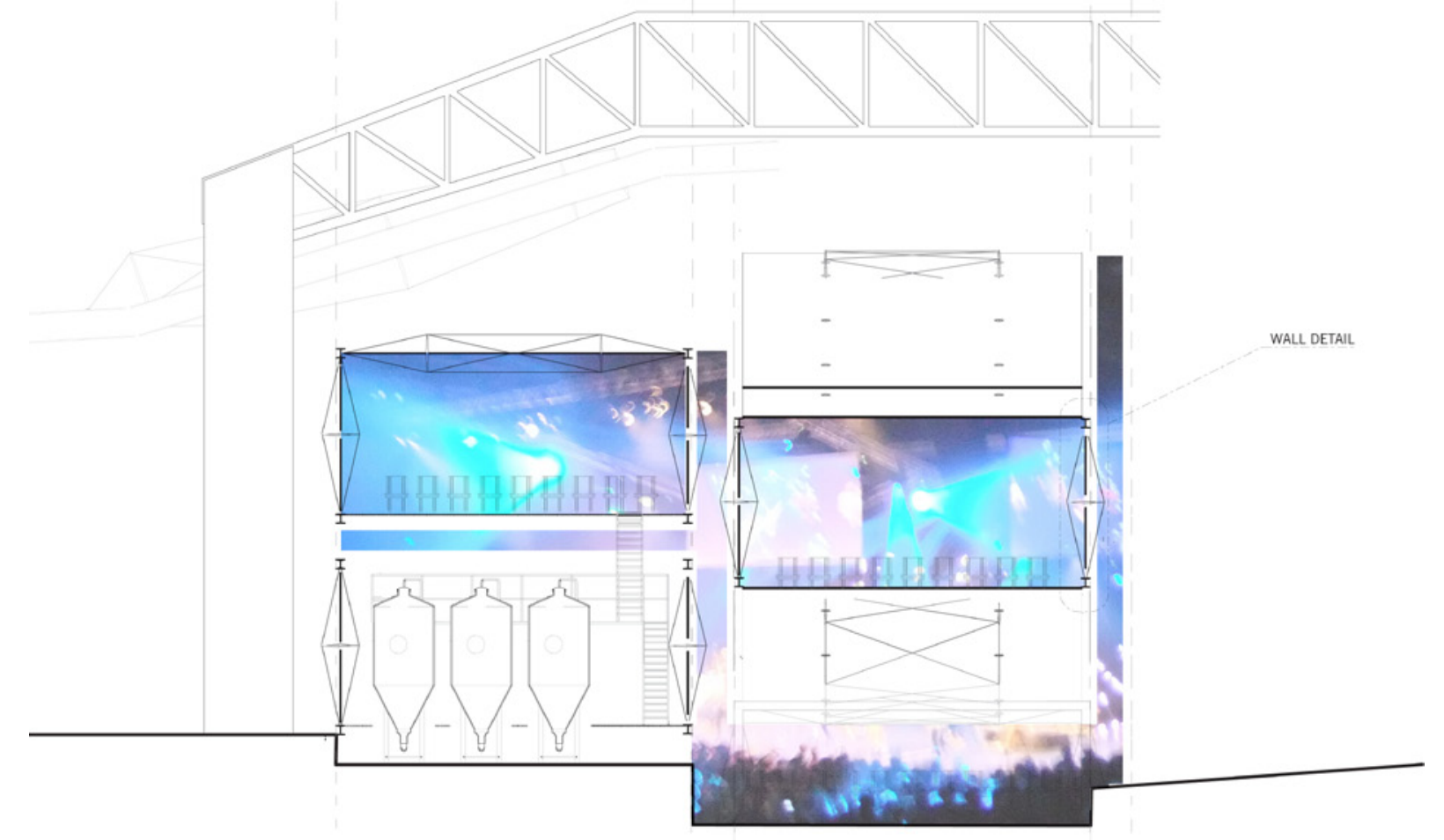

Fig. 127 - Design Iteration Five Brewery Audutorium Section C, By Author 280

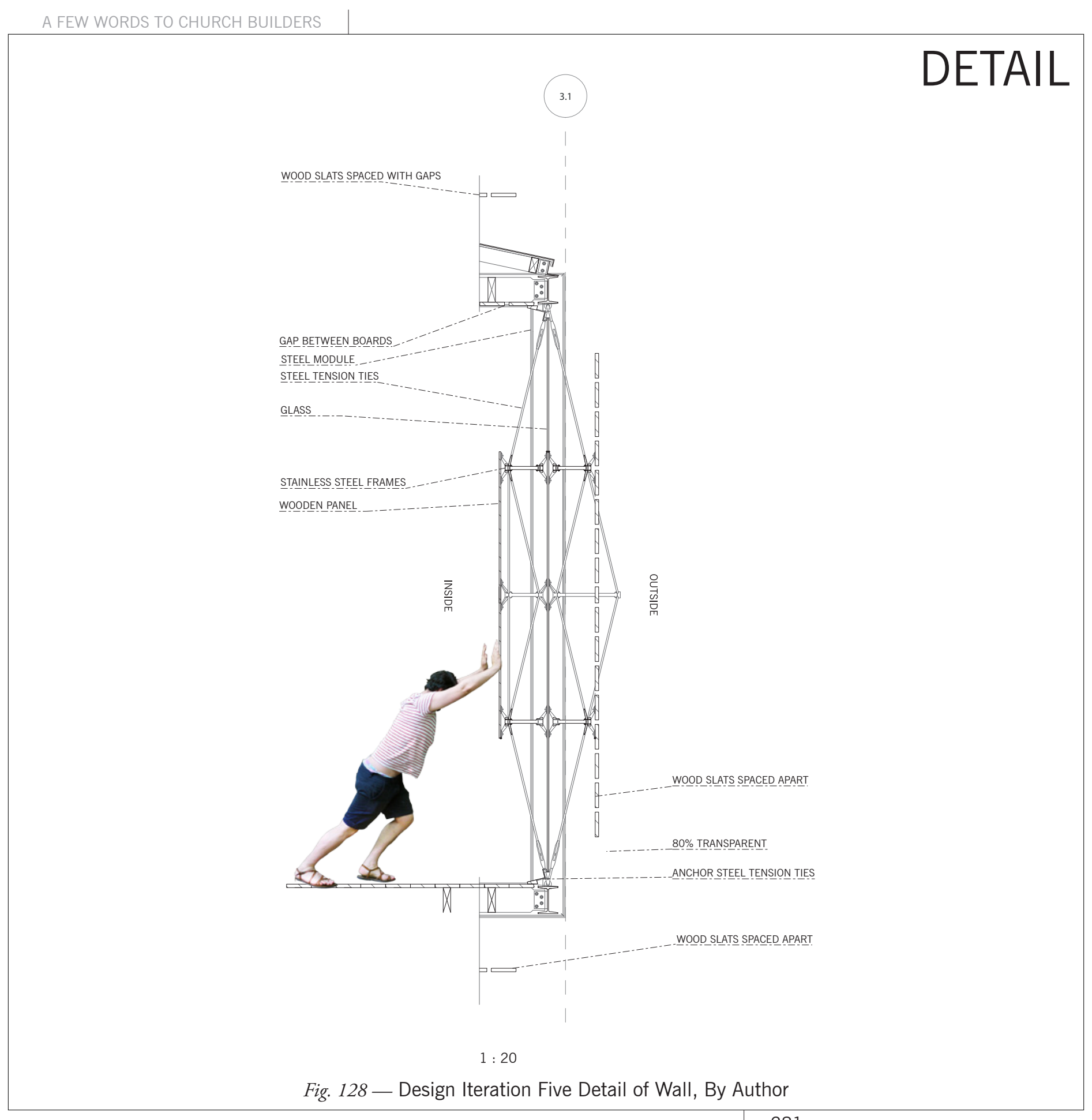


Convoluted by multiple reactions narrative to clearly communicate the to theogy Design Itemion Fire Complicars the arch lecrution Five comper the architectural narrative between the secular and sacred. The architectural manifestation of secular programme and church is too complex to answer the main issue. Tschumi discusses the need for concept, 'a concept-not form, as some
would suggest- is what distinguishes architecture from mere buildings.' It archtecture from moce buildings.' It stance.

Fig. 129 a sacred space has order, a central point, Critique develops in plan a synthesis between secular forms and worship space. The following design will treat the secular programme as a second architectural identity. This will allow the secular and sacred fo dilow dialogue and facilitate the theological

Fig. $130 \mathrm{~A}$ plan in critique of design iteration five, simplifies thearchitectural

1. Tschumi and Cheng. 2003. pg 64

receptive, welcoming nature of $\mathrm{CHURCH}$ within the architecture of the Church. The hatching critiques threshold in the same method as previous threshold critique which illustrates a permeable envelope not restricted to one wall or
A INTO CHURCH FROM PUBLIC

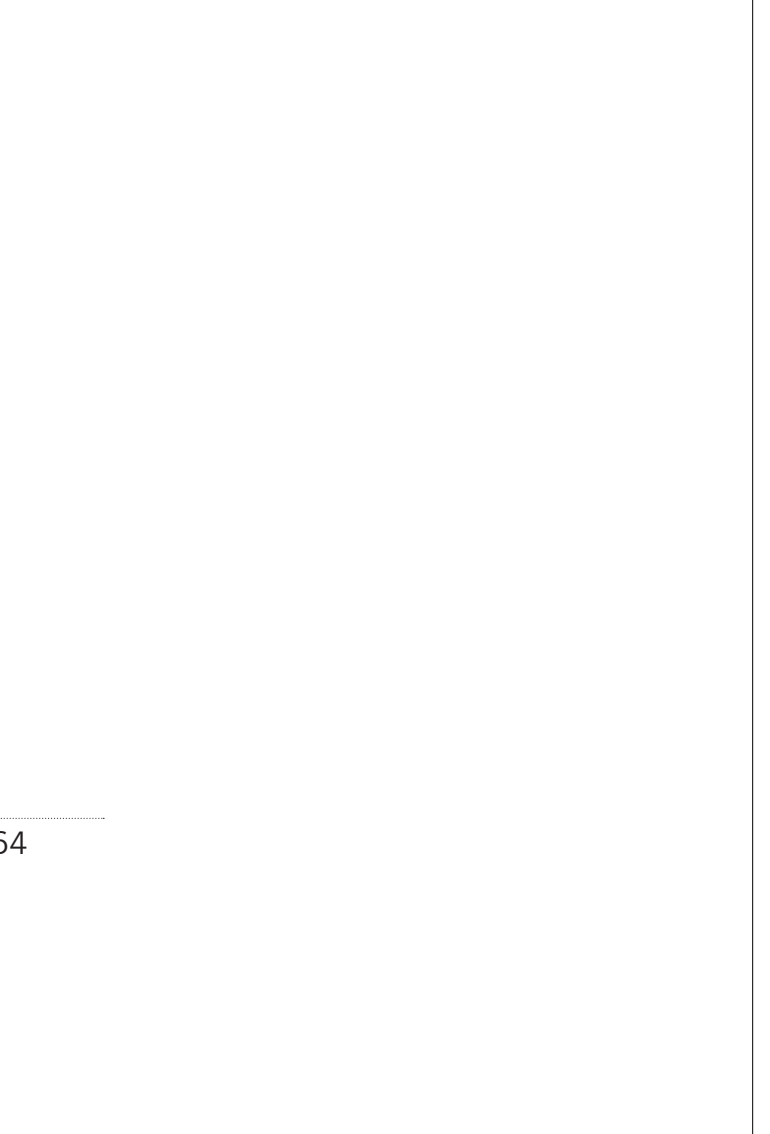

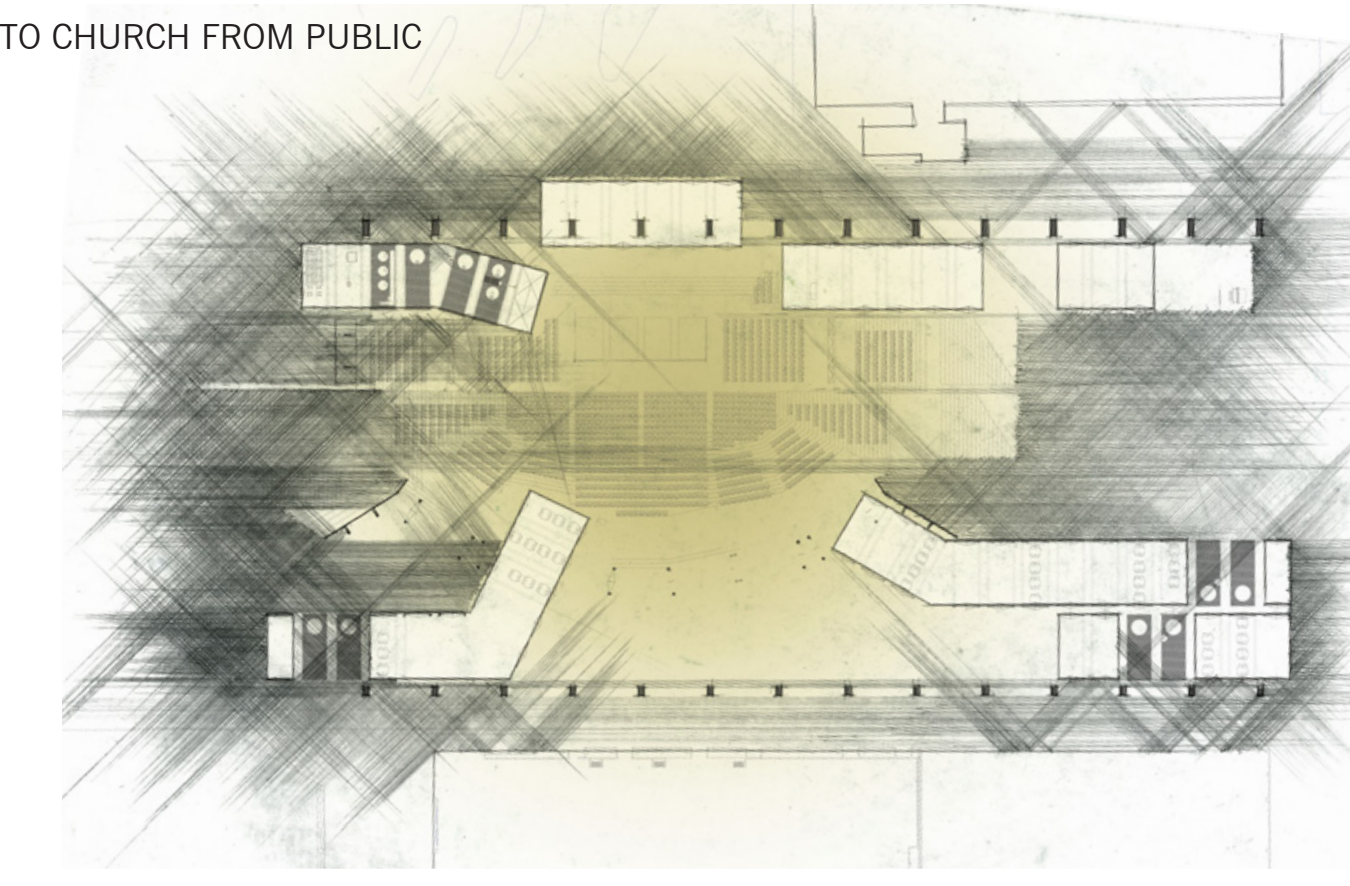

B INTO CHURCH FROM SECULAR PROGRAMMES

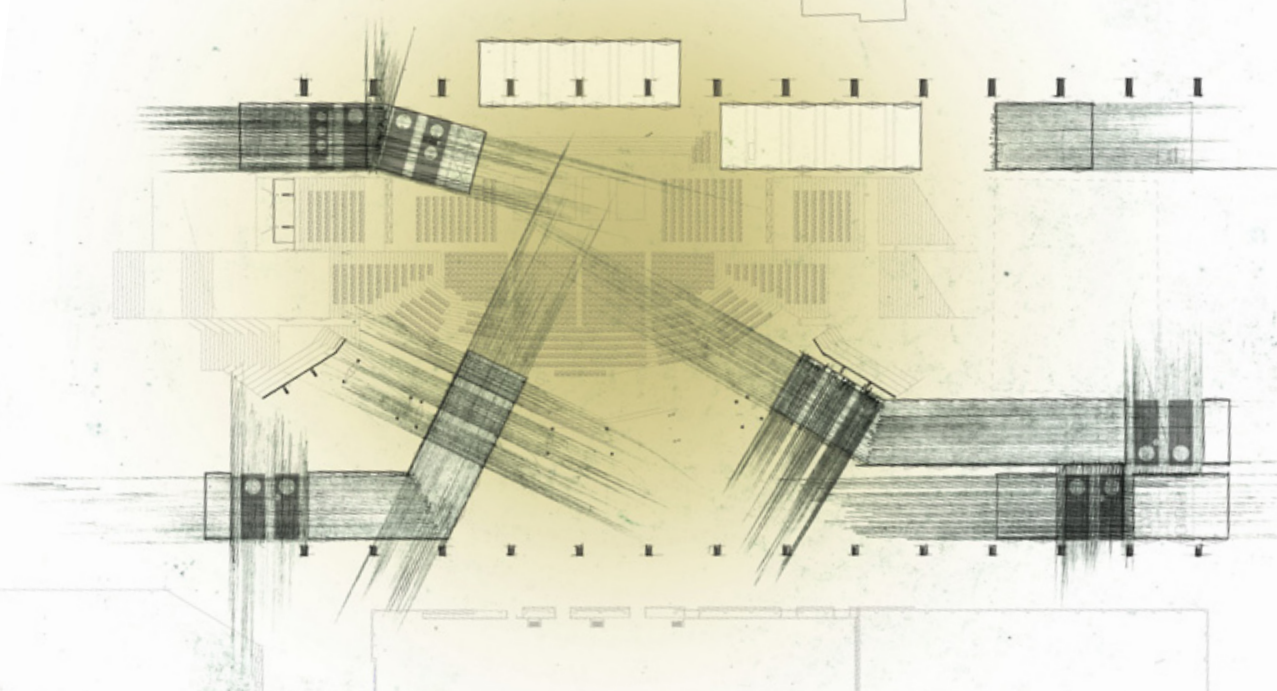


A FEW WORDS TO CHURCH BUILDERS

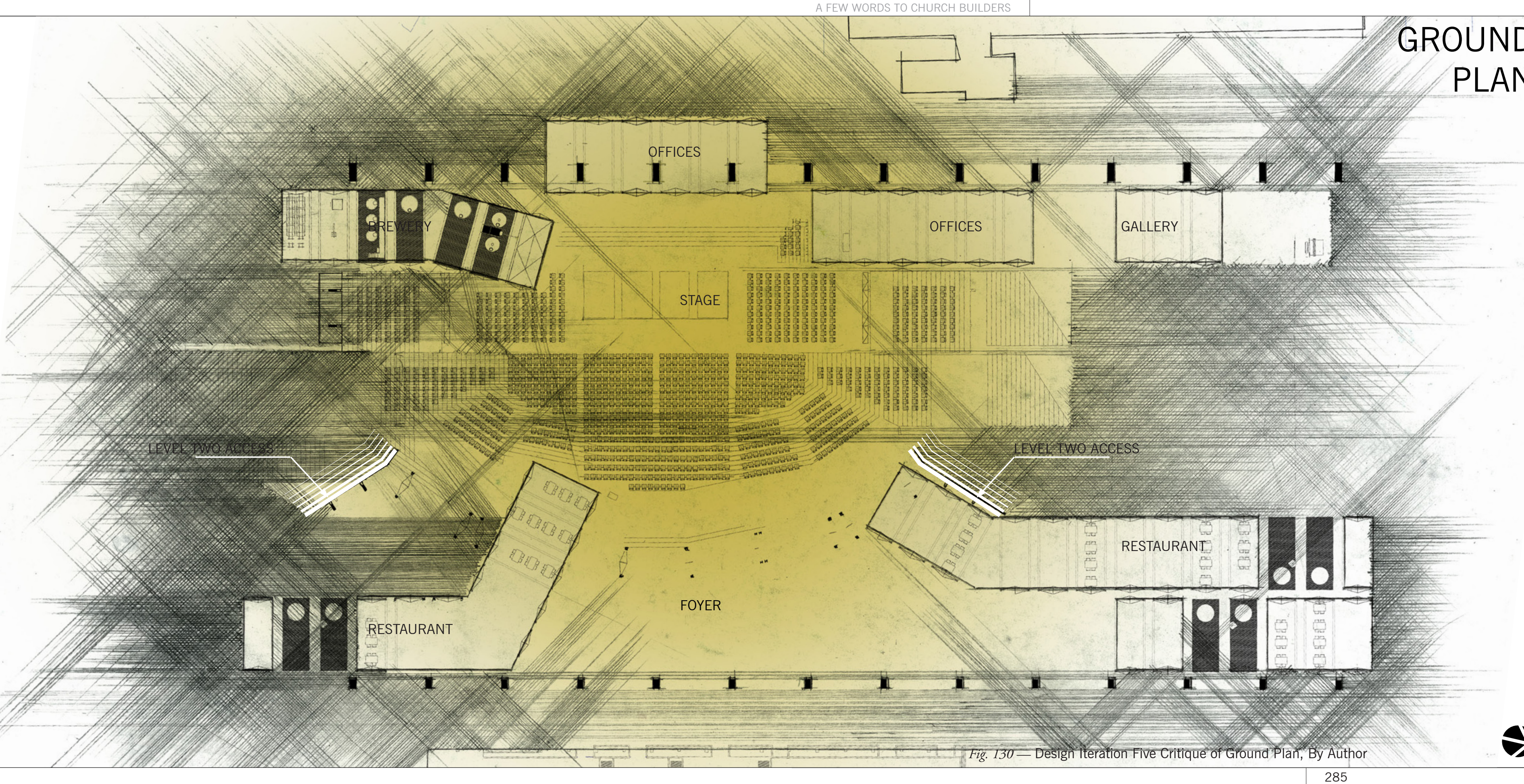

$\diamond$ 


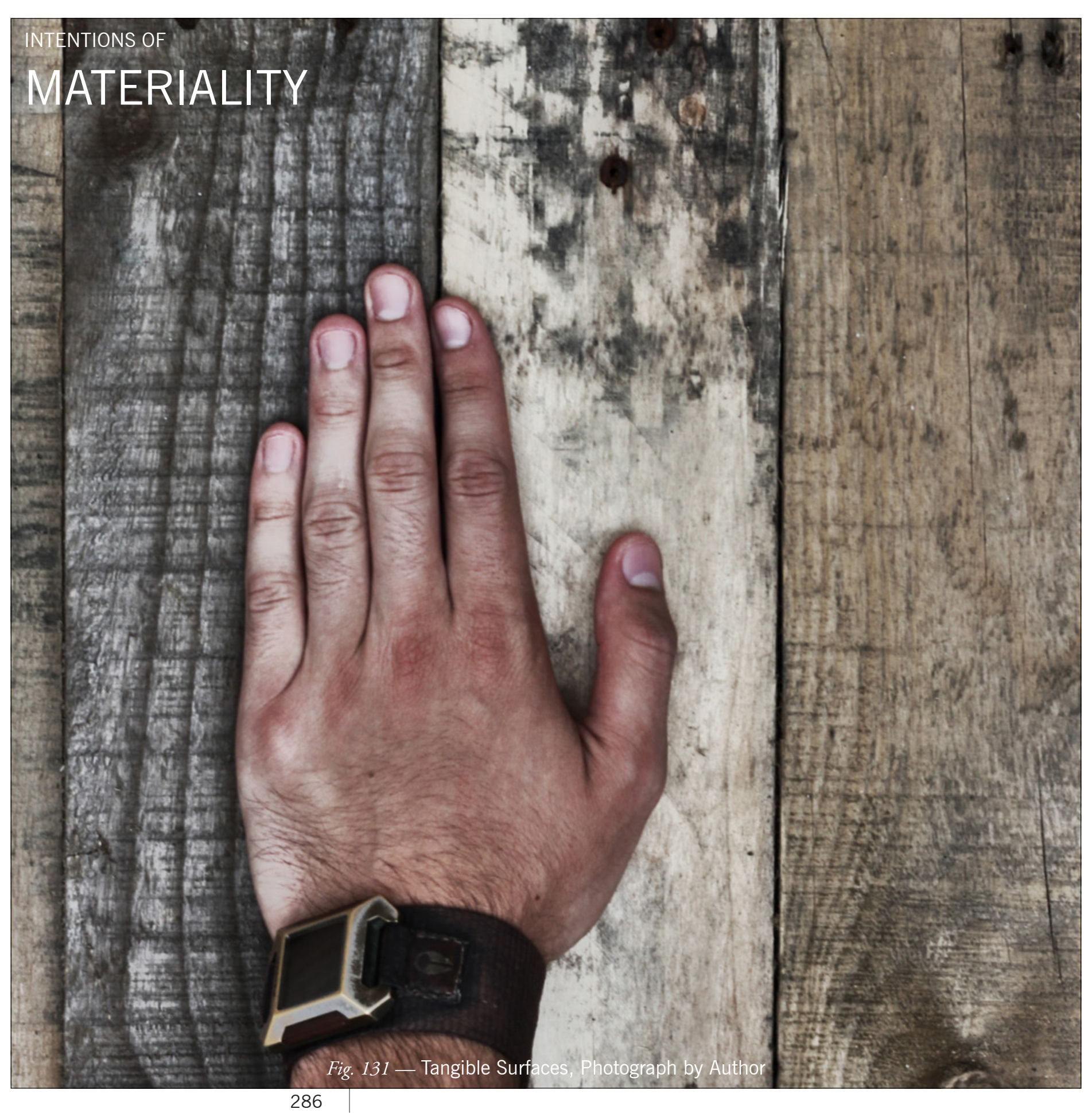




\section{DESIGN \\ ITERATION}

SIX 
Design iteration six defines an to architecture. Strange new shapes architectural dialogue between the may inspire delight but, conversely, sacred and secular where wood and may appear excessive, impractical, concrete are used as metaphorical or even frivolous. ${ }^{1}$ Form alone will identifiers of these programmes. This not adequately communicate the $\begin{aligned} & \text { material use provides a visual narrative } \\ & \text { of the secular inclusion in the sacred. }\end{aligned}$
materiality and programme all contribute to an overall emphasis.

Fig. 132 illustrates the concept of

'blanket,' whose conceptualisation The following paragraphs describe of Christianity drives form; covering images illustrating iteration six.

of Christianity drives form; covering secular and sacred alike. The CHURCH

form is responsive to the secular Fig. 133 develops upon the notions

structures, lifting itself up to allow explored in Fig. 134; the maquette

a secular insertion into the space of explores 'blanket' and its architectural

worship. Form demonstrates a sacred repercussions, driving the architectural and secular blur while portraying representation of the CHURCH and the movement, a notion representative architectural relationship with the of ARISE CHURCH as seen in the early secular. The maquette is photographed 'envelope' study.

inside a sectional model of the TSB,

and is seen responding to a block

Iteration six simplifies the sacred resembling secular programme. and secular blur attempted through iteration five convoluted form

Tschumi wrote that 'form implies a

set of issues and explorations internal

1. Tschumi, Bernard. 2003. pg 49

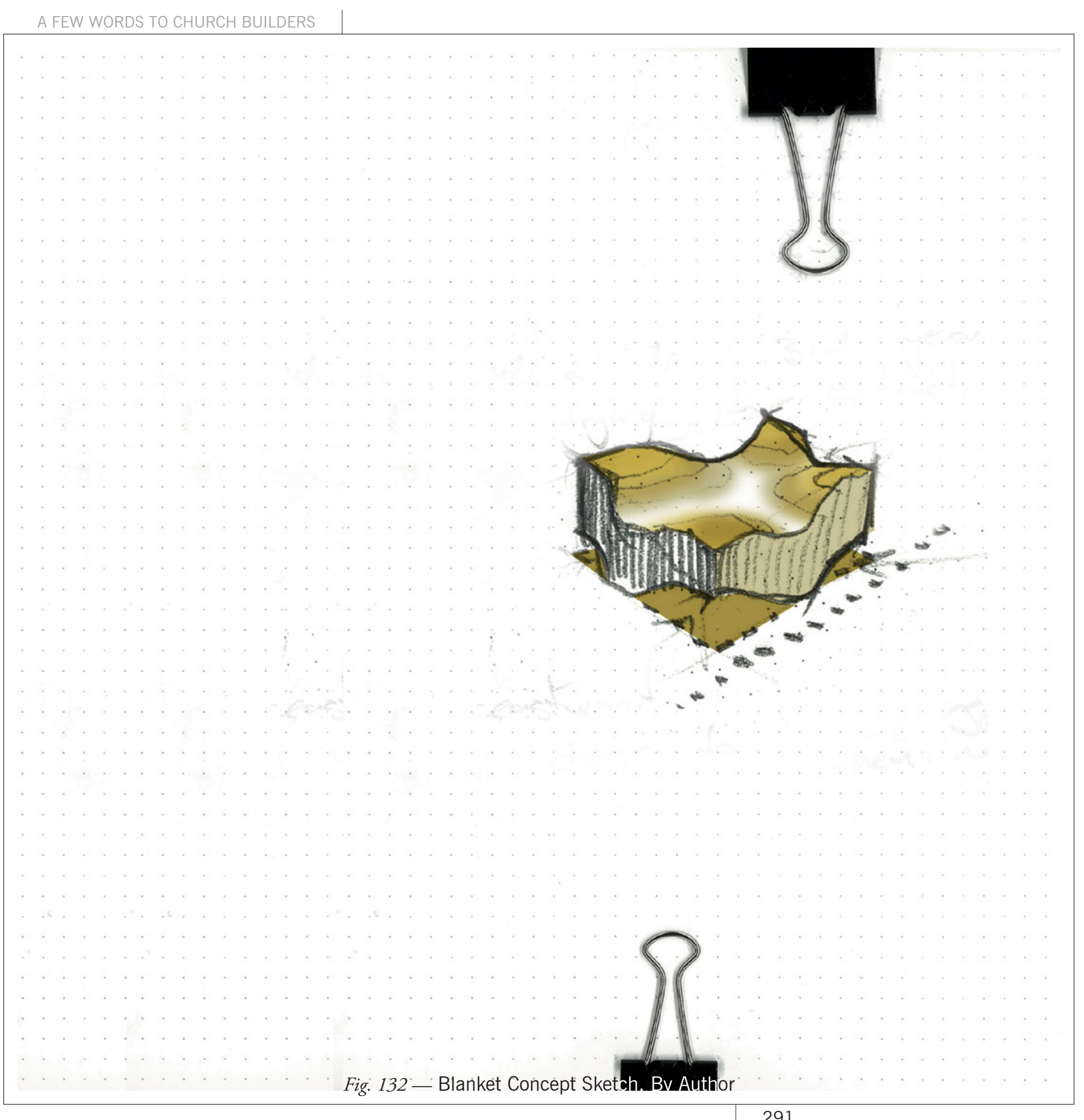




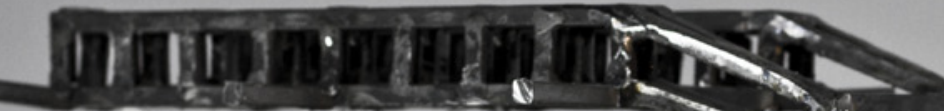

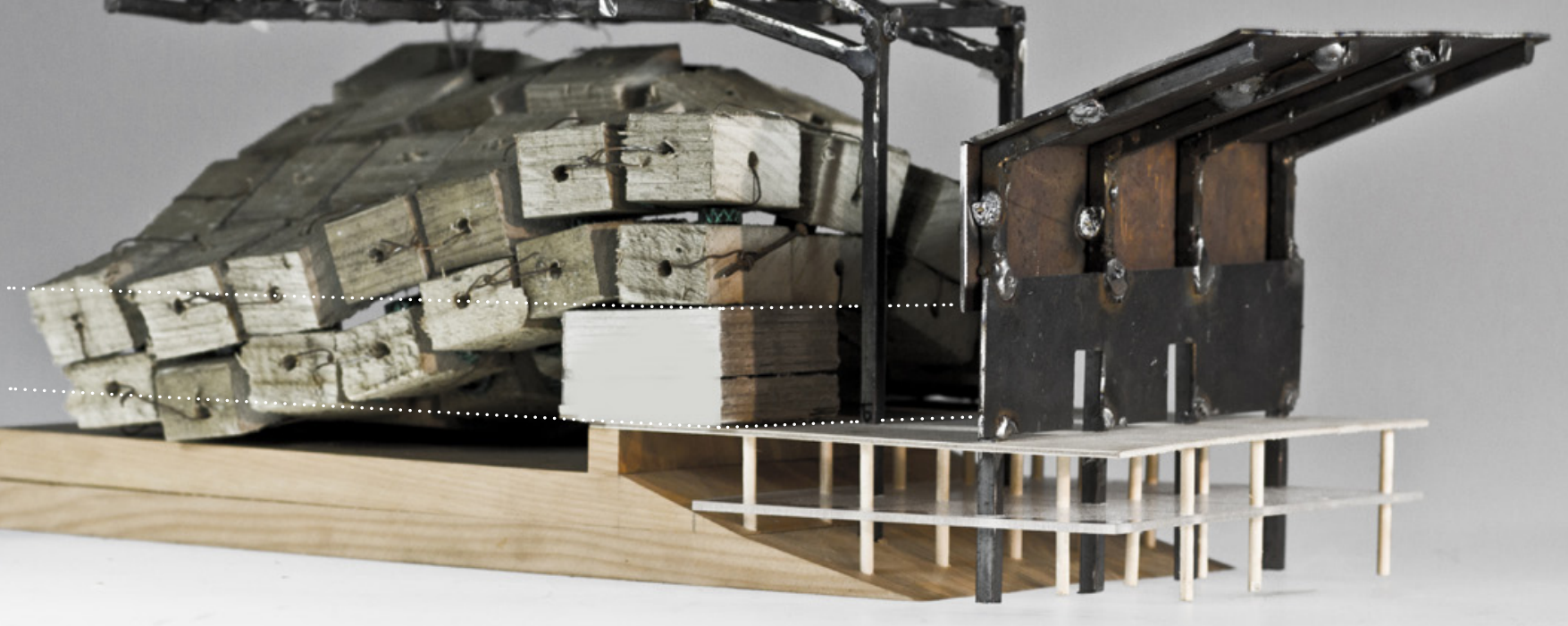

Fig. 134 illustrates the Church from the southern approach. The secular concrete pavilions house the brewery (left) and restaurant (right). These structures sit under the Church 'blanket.' Externally they each look away from the church, the restaurant looks to the water. As they enter and orientate toward the stage (fig 132) form becomes attentive toward the stage. Illustring the tow stage. point of ey helled down to a hu scale at the points of enty remiscent scale at the points of entry, reminiscent ton tho's need for human scale.

Fig. 135, wood clads the outside and inside of the Church, it materialises a truth of representation, while externalising the Church. Fig. 136 illustrates the brewery's insention into he Clyct Resting the secular is included in the sacred, unaltered. The worship space is made approachable to the passerby through the existence of the secular in the sacred. The figure also illustrates the semi tra the also illustrates the envelope; spaced shats allow some light to pass through the envelope.

Fig. 137 illustrates in section the overlap between secular and sacred intersecting the worship space, foyer, brewery, restaurant and public realms. The location of this intersection disrupts a continual auditorium rake allowing the contributing parties inclusion in the Church event. 


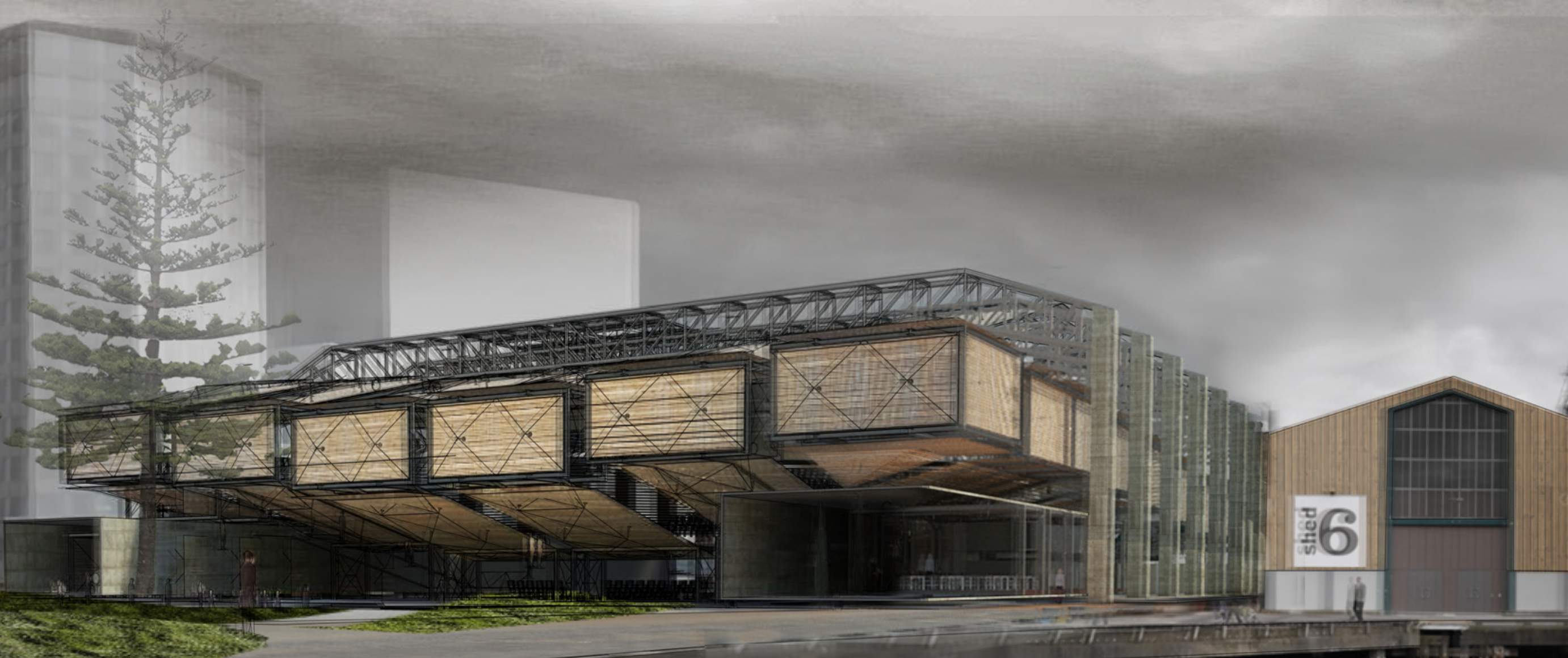




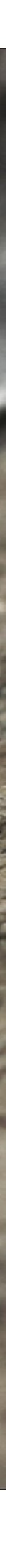



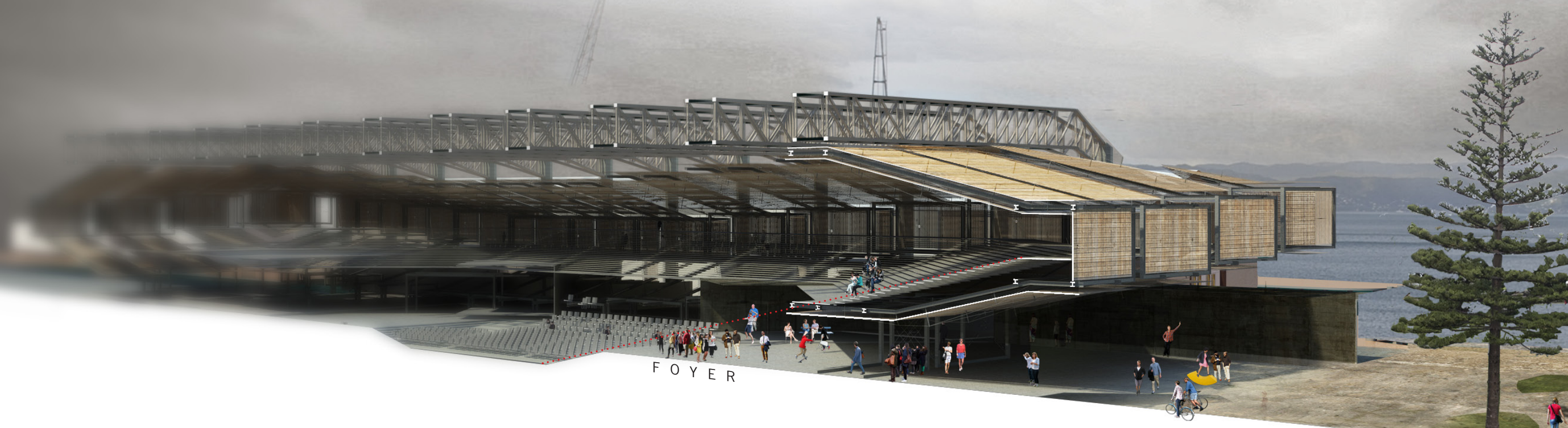

nas

2ite 
CRITIQUE

Design iteration six succinctly resolved life, not just in some religious realm, envelopes mediation between sacred somehow distinct from the secular and secular programme. In doing This is achieved through the secular so it refined a form representative forms inclusion in the space, the cafe is of both theological stance and ARISE in the worship environment, intended CHURCH. Design no longer coincides to be an extension of the auditorium the threshold between the secular and seating.

the sacred with the building fabric. A

consciousness of God can be found in

the secular and sacred environments

like while the sacred is made pabts

to those unfamiliar with, or those with

preconceptions of Pentecostal Church

environments. This Pentecostal

architecture is inherently a specific

response to social context (site) and

ARISE CHURCH.

Fig. 138 develops upon iteration

six, influencing the final design

proposition. The overlap between

secular and the sacred, intersecting

in the foyer are the auditorium and

secular programmes. The space fulfils

Robinson's desire to help people see the

influence of Christ present in everyday

1. Torgerson Mark, 2007, pg 17
The design has previously focused little on the needs of the congregation. Iteration six and final design redefine distance between the cental worship space and the public sphere, bufferd This concept removes the worship environment enough to retain congregates security and intimacy with metaphor would otherwise suggest. by the foyer and secular overlap. God, not as the fish in a glass bowl

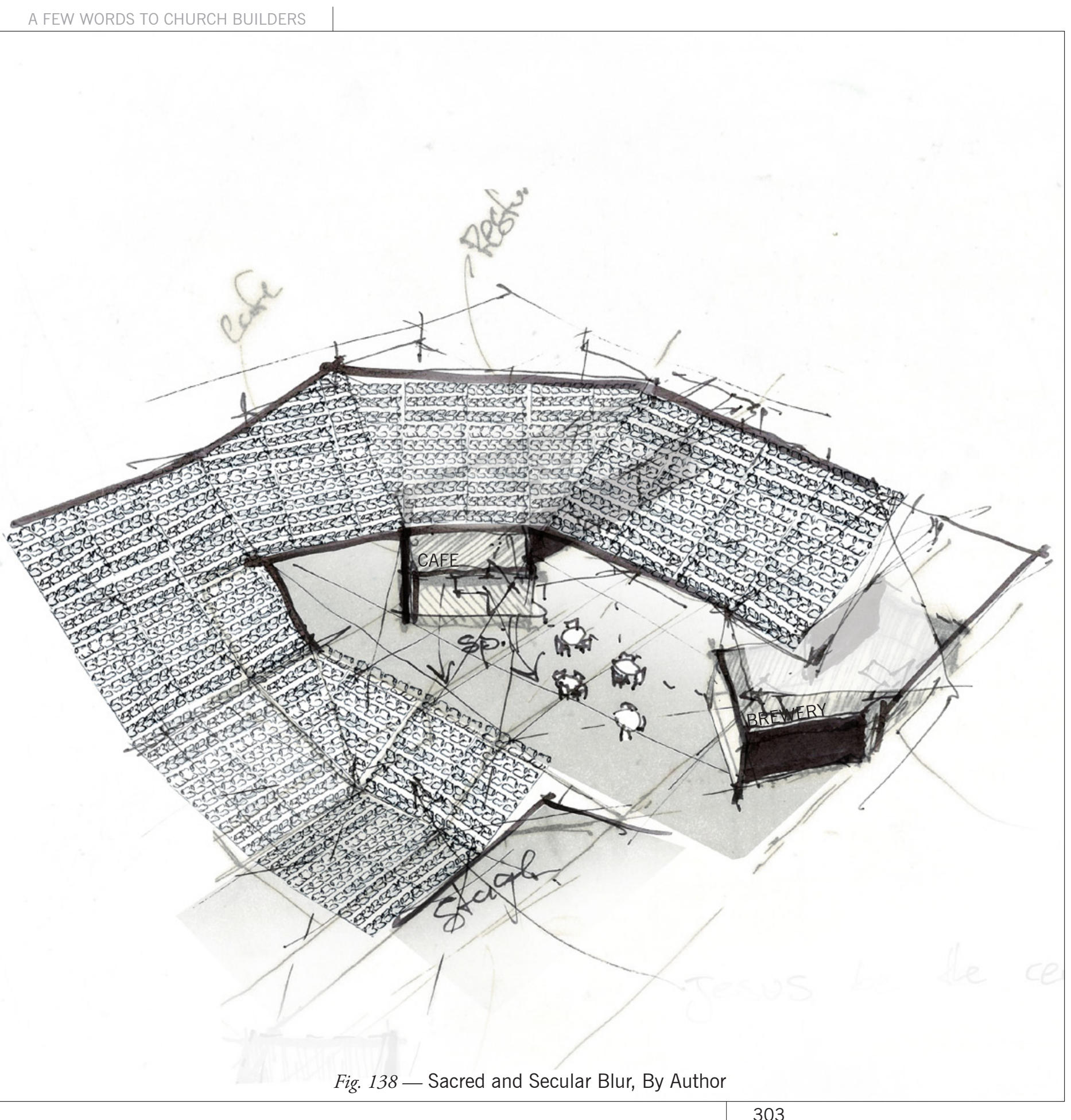




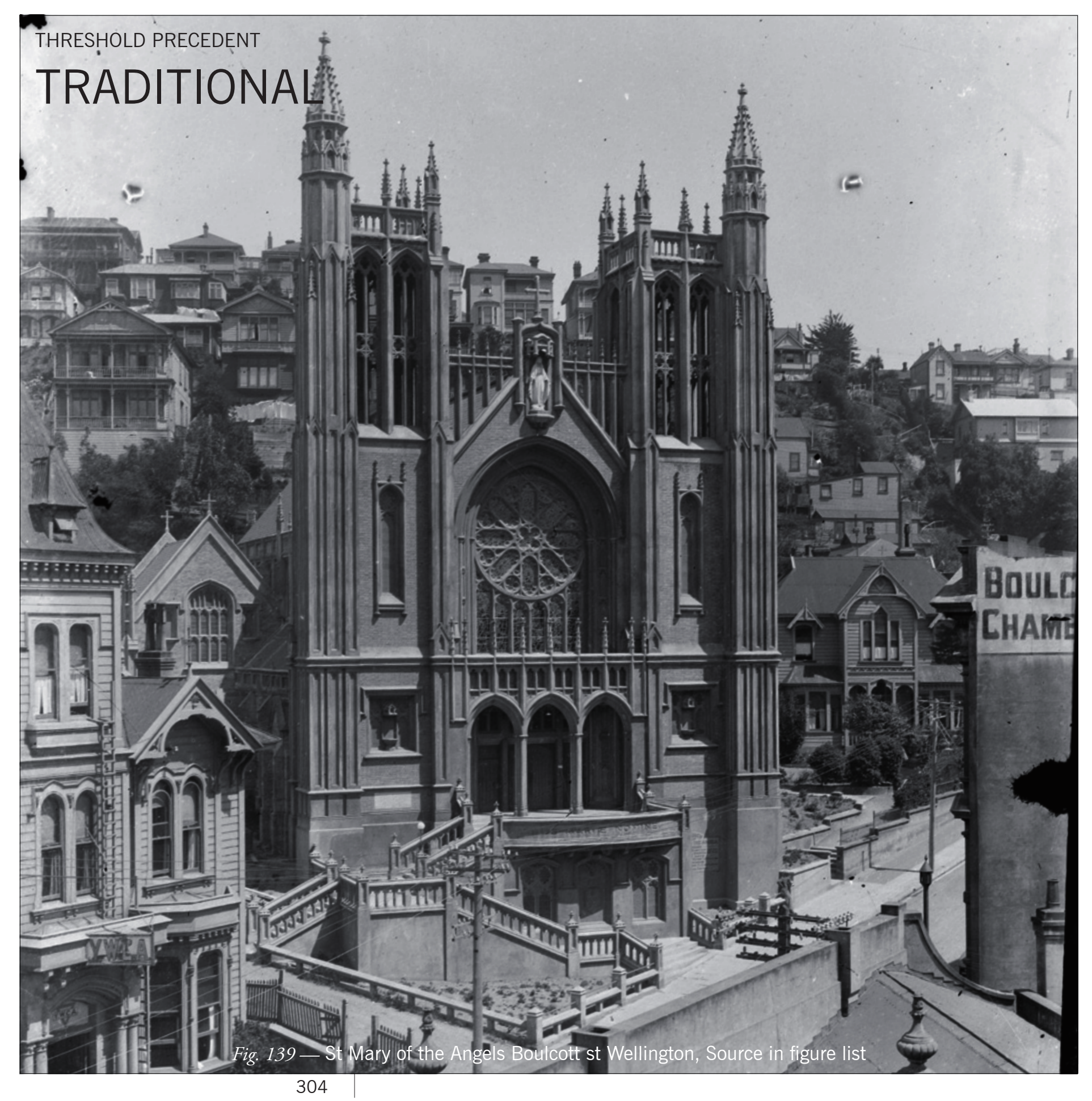

COMPARISON

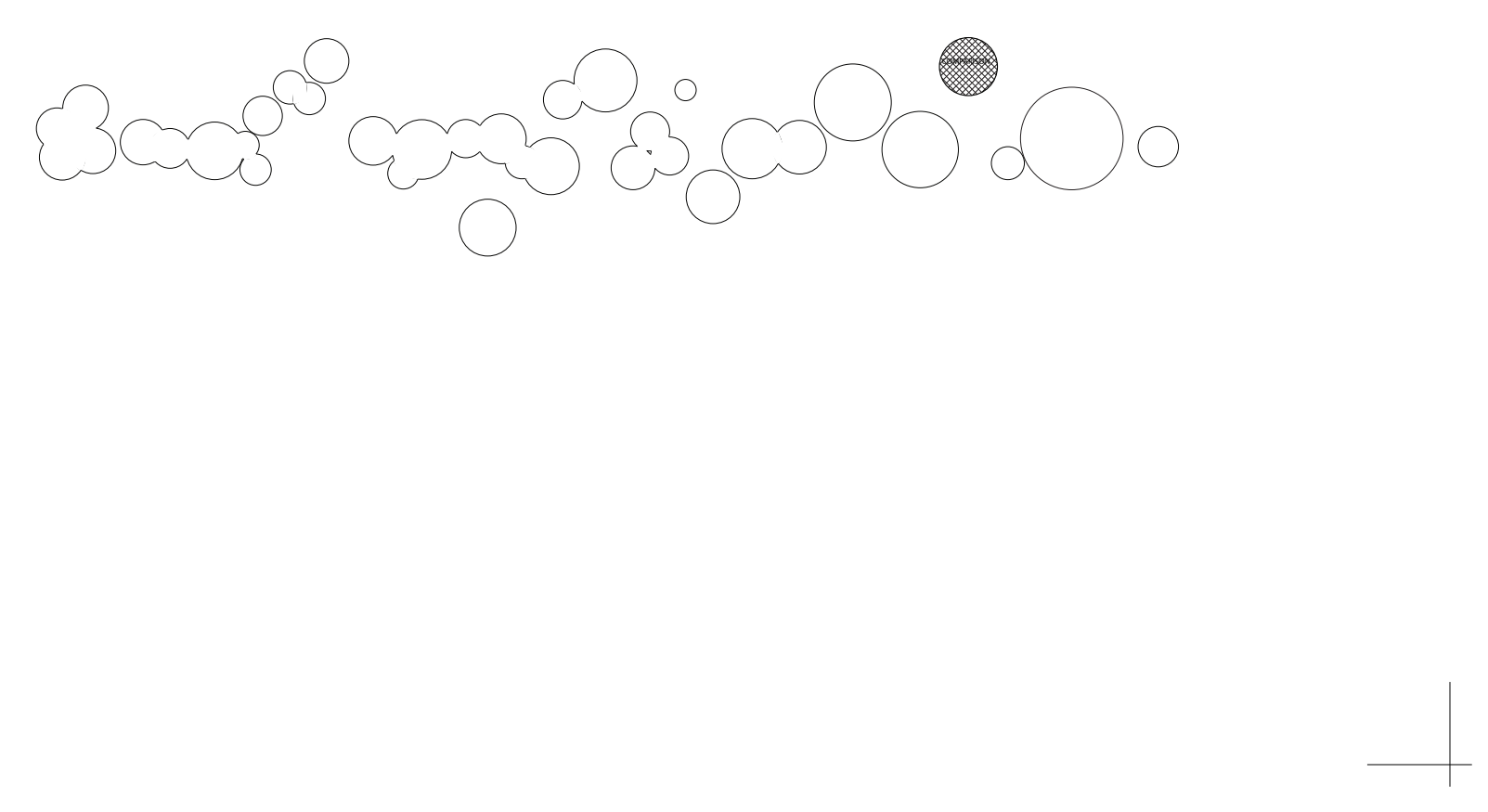



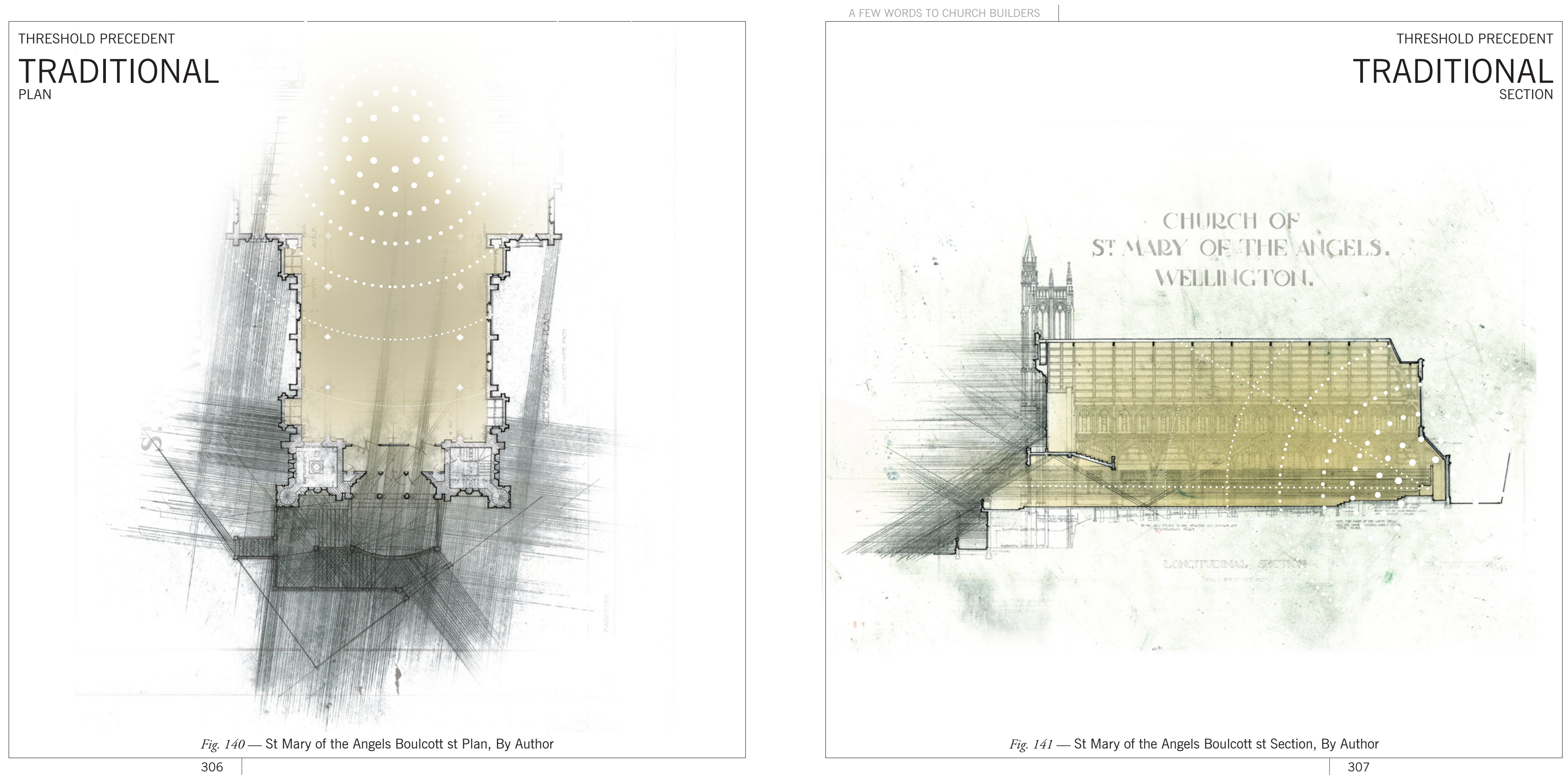


\section{CRITIQUE}

The thesis has constantly subjected design to precedent critique. This chapter subjects design comparatively to thresholds that are, 'traditional,' 'departing traditional and 'challenging traditional.' This critique will gauge the success of the current design outcome and its position within Christian

architectural contexts.

step ' 3 ' and finally another steep, faced with the altar with a lower ceiling ' 4 . The Catholic Church according to Gonzaga in his thesis Sacred threshold outlines the Church threshold as a journey, 'passing from one life to another."

Traditional threshold is here dominated by facade ' 1 '. You are often

The traditional threshold analysis refers to a local Wellington Catholic Church, St Mary of the Angels of a traditional axial plan; a plan which follows a direct trajectory towards the altar from the front door. The altar as centre piece focus the architecture. "Scale and volume, use of light, articulation of decor, and organisation of space' adequately communicate Gods transcendence.

met with a large shallow wall, a very distinct thesheld. Design prom a very

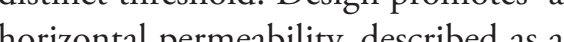
tion on immont described as a through a spatial depth, form and envelope lineate any oppressing verticality or building weight.

Following Threshold investigations critique a Church of the modernist movement, simplifying the traditional cannon of criteria followed by Hillsong New York and the Sacred Broken down into a series of moments the building threshold subjects secular overlap seen through an the occupant to the facade and insertion of Church into a bar within compression ' '1,' the release '2,' the New York City street scape.

1. Torgerson, Mark. 2007. pg 6 

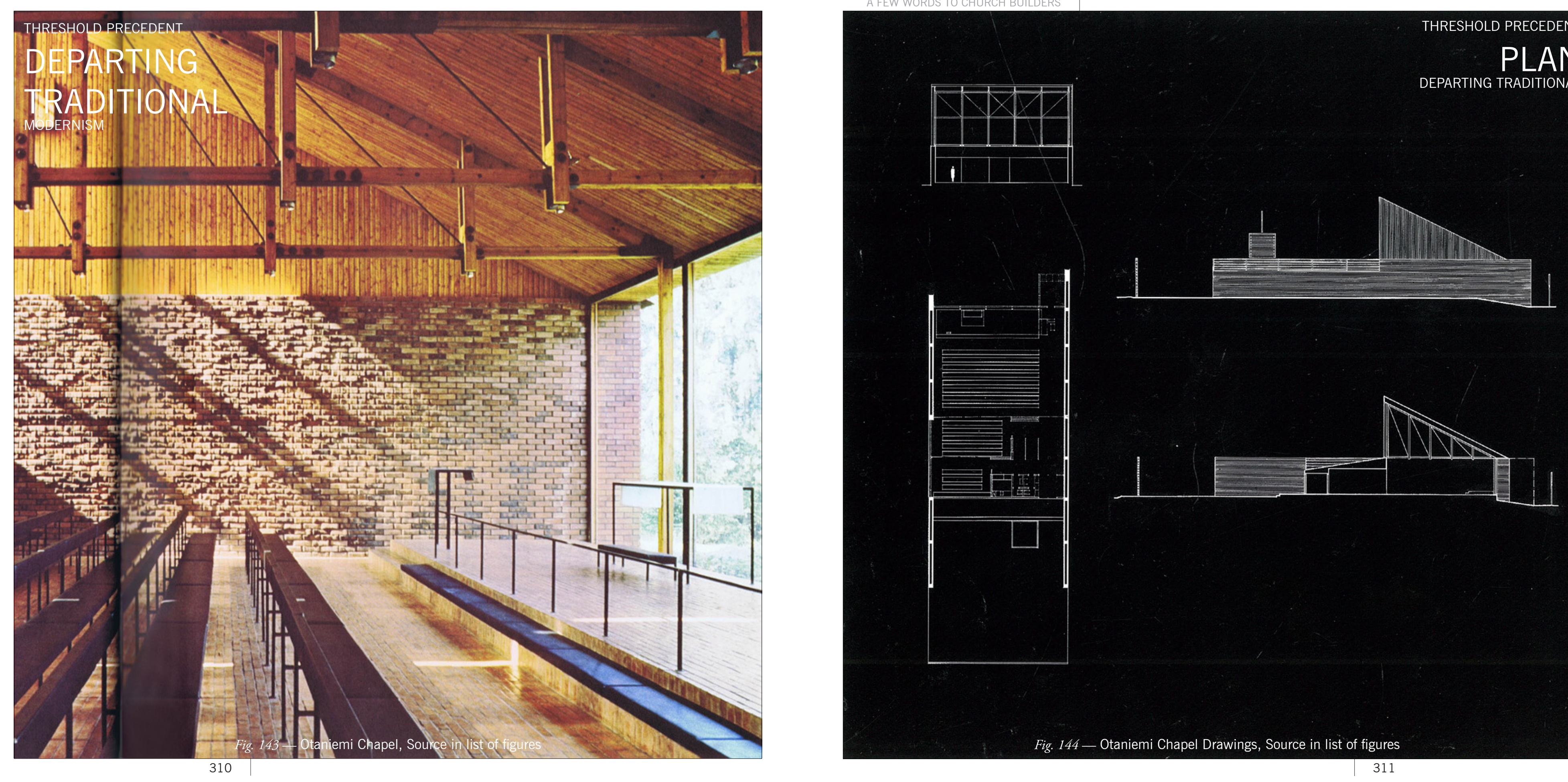
The Otaniemi Chapel in Finland Sacral Space; 'the holiness of the chapel is compared to design phase six, due is no stiff solemnity or ceremonialism. to the design of its threshold which It is receptiveness..$^{{ }^{4}}$ Jetsonen goes on departs from a traditional internal to say the Church allows 'one to enter (other worldly) focus to an external the Church with plebeian thoughts in attentiveness. The Otaniemi Chapel mind, and everyone can bring their 'presents a rare consistency of form and detail.' Spatial layout leads entrants through the forecourt directly 'through a vestibule occupying one corner a vestible corner of the builyng. view over the chapl to the alar wall of glass, to nature and a cross standing outside. $^{2}$ own idea of holiness.'

This piece of architecture manifests notions of acceptance and externalism This pice of architectre masts chapel is a trentive and awa che is atchive and awre of the changing external conditions. The Church forest relationship parallels the city, Church relationship, outside The building draws the external is inside and vice versa allowing a soft environment into the space of worship. transition through threshold. The Heikki and Kaija Siren architects continuity of concept through form, used a south-facing clerestory light envelope, materiality and detail affirms source from above and behind so that its theological stance.

the people sitting in the nave could see through into the woods. 33 The dialogue between form and detail is Church attentive towards the refined to simplicity while the limited external conditions of the city of material palette affirms the architect's whose receptiveness allows someone intentions. Jetsonen writes in the book unfamiliar with CHURCH access.

1. Walden Russell, 1998, pg 15

2. Jetsonen Jari, 2003, pg 30

. Jetsonen Jari, 2003, pg 30

5. Jetsonen Jari, 2003, pg 30

6. Jetsonen Jari, 2003, pg 30

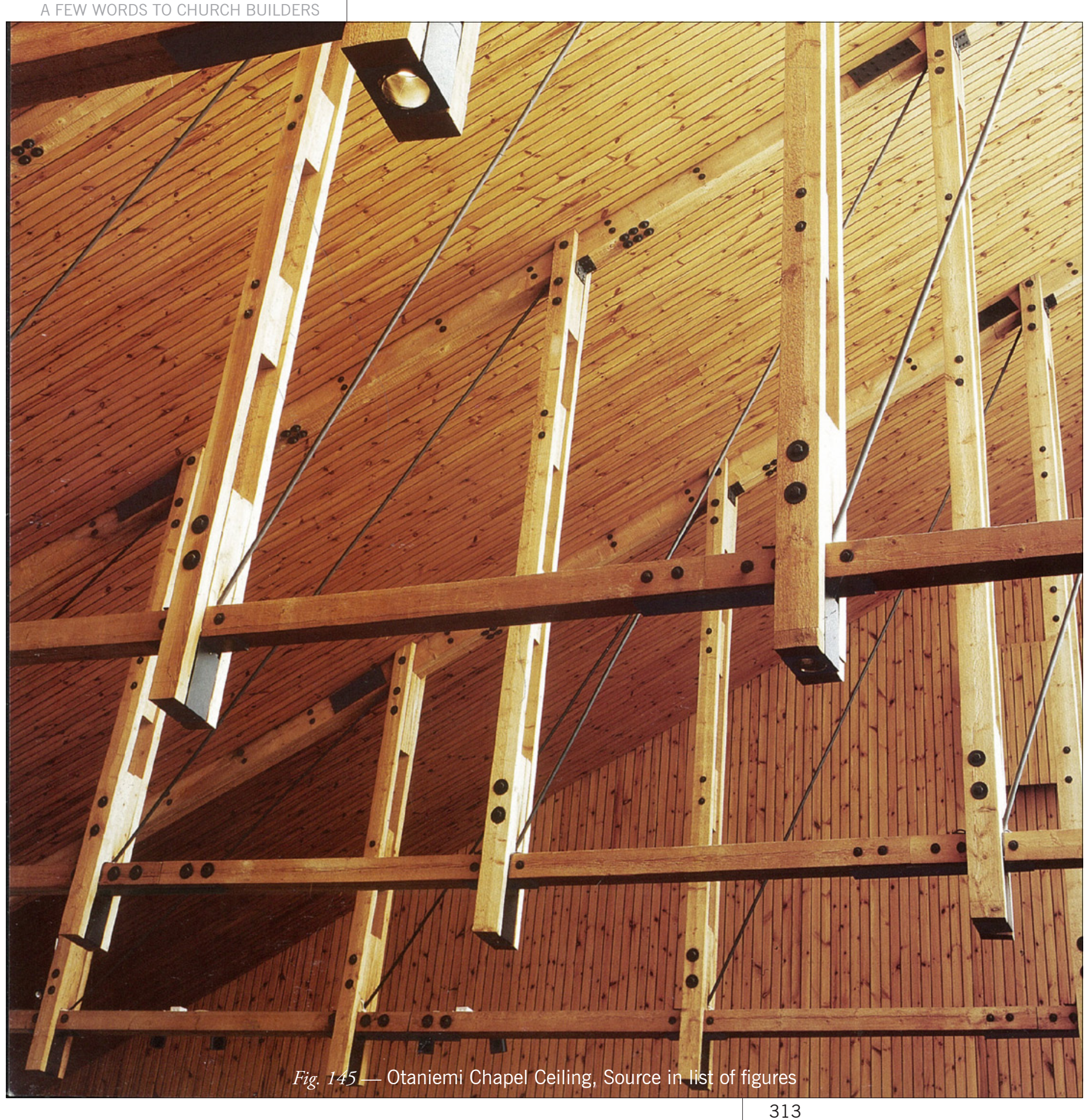




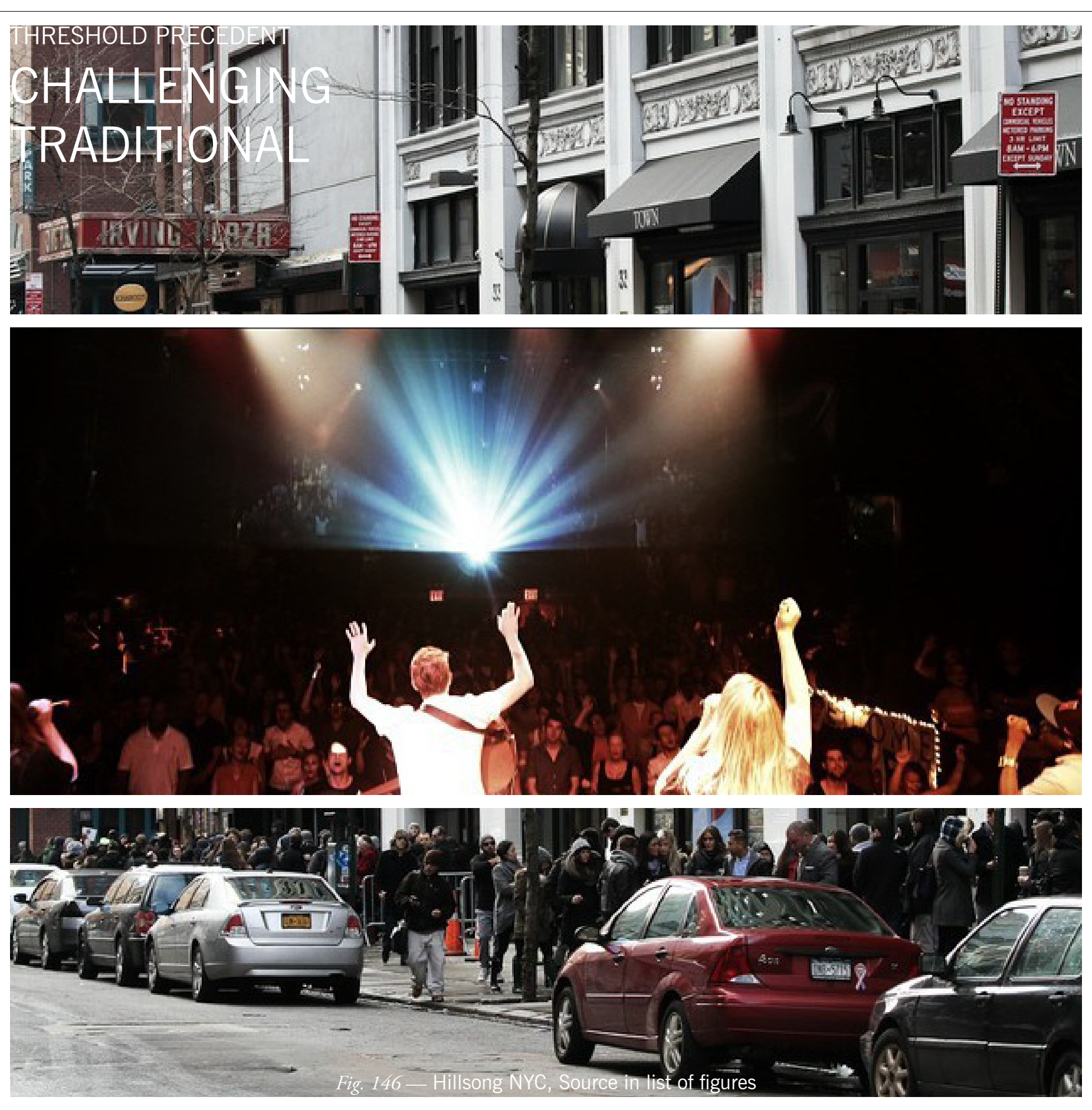

Hillsong CHURCH New York share a similar theological approach to ARISE CHURCH. They provide a good platform to critique an architecture seeking to enable a contemporary liturgy with response to social contexts.

Architecture must respond to the context of the community it serves and the community it wants to seve. and the con Design aims to solidify a presence of ARISE CHURCH within Wellington through the design of a structure that responds to the community outside the CHURCH. This is an architecture of receptiveness, like the Otaniem Chapel, it will express 'no stiff solemnity or ceremonialism

Hillsong New York currently rent venues, Typically 'Irving Plaza' the venu a club into church on Sund this vente in This venue enables a contemporary liturgy within social contexts of New York City. The street scape is littered with clubs, bars and theatres and where

there is a social hesitancy to enter a Church. ${ }^{2}$ Carl Lentz (pastor) says the building is one of the CHURCH's best tools, claiming its more palatable to come into a place you recognise.

Huffington Post, an online news aggregator and blog, interviewed local New York music persolity 'J Rucal Newe' collo colloquially stated. 'I go into a CHURCH right here in the city....... And from the moment I walked into Church I said OK, this is where they mean "come as you are." They TURN a CLUB into a CHURCH on Sunday."

This quote outlines the social context in which Hillsong New York responds. The building aids in breaking down The builing peceptions of God as separate from pere attainable and receptive to all. Although not a specifically designed piece of architecture, it is the closest precedent to which design investigation relates. 2. Lent, Carl, interview by Ahmed 3. Shihab-Eldin. 2013 isvew by Ahmed 4. Lentz, Carl, interview by Ahmed Shihab-Eldin. 2013 


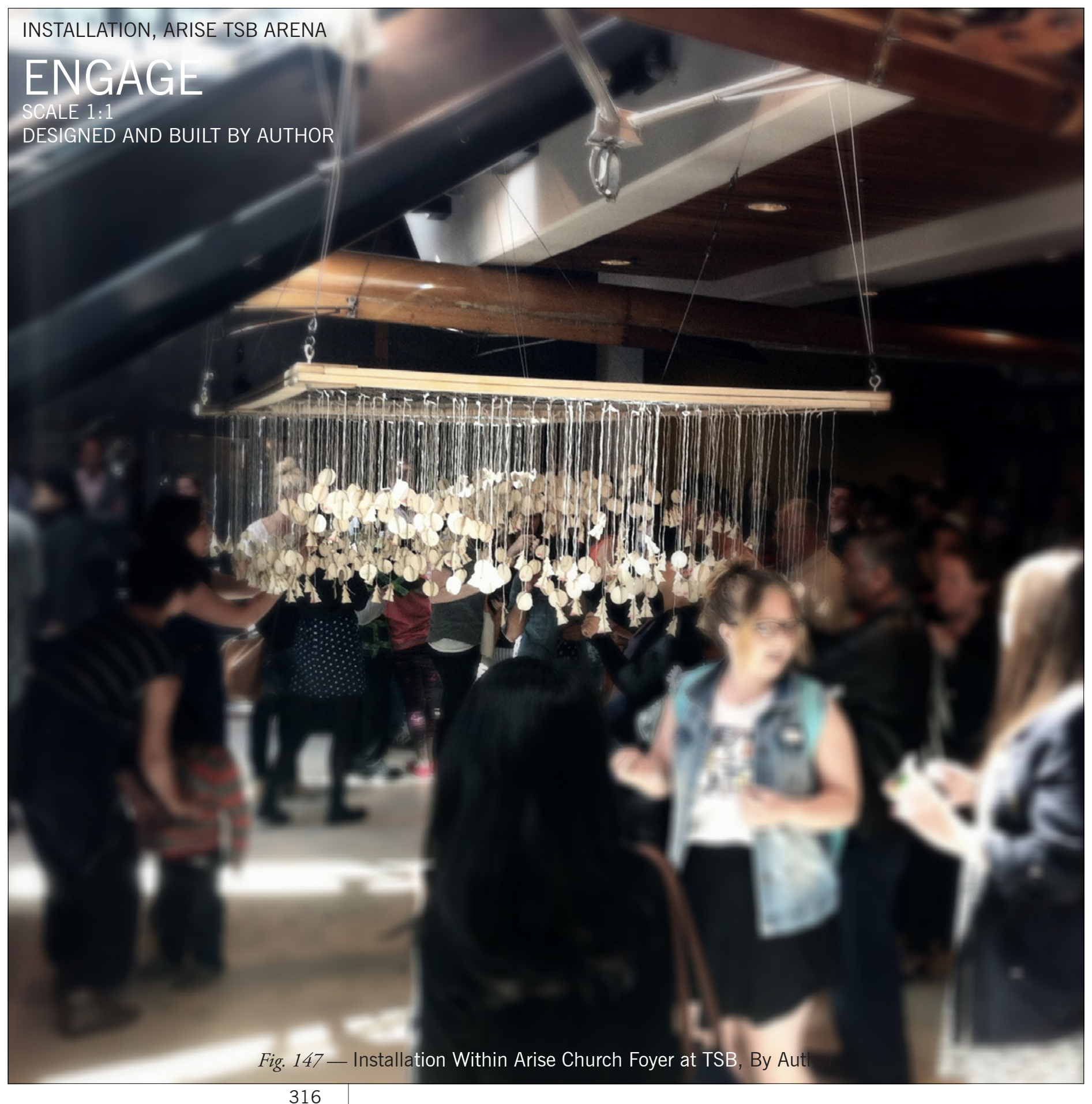

\section{REITERATE}

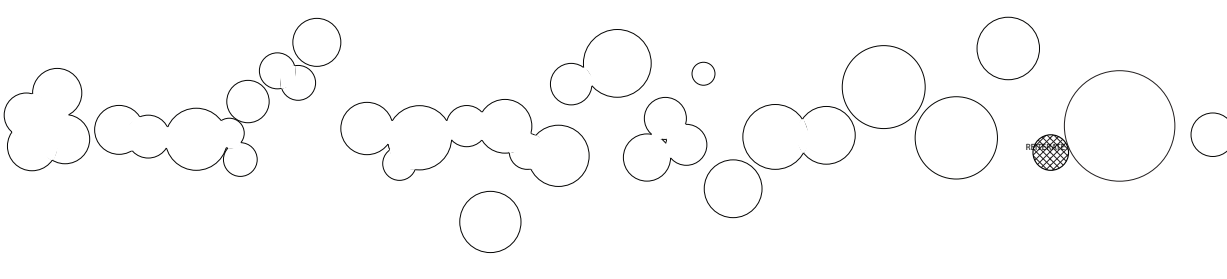


An ARISE CHURCH service contains music and sermons of a contemporary nature, applicable to current socia contexts. Architecture is in a position to engage the secular environment in the performance allowing them a better understanding of the $\mathrm{CHURCH}$ operation.

The current rented typology used by down notions of God restricted to the religious, while also disassociating space with encounter. The rented typology achieves this while at the same time denying the $\mathrm{CHURCH}$ a physical presence within the city and restricting who enters due to the Performance venue's inherent nature of creating high intensity of threshold.

A physical Church building makes a physical proclamation a physical proch biritua into monumentaly. The arcitectre into monumentaliy. The architecture seeking to improve the CHURCHEs relationship with social contexts uses programme, form and envelope to nifest and facilitate a reception of the external (secular) environment. This inclusion affords the secular an acceptance and knowledge of the CHRCH operation. installations within ARISES CHURCH foyers. The installation embodies eology through form; an understanding of its purpose is found through visual and physical engagement. The suspended pendants represent a community of children requiring Christmas presents. The combined pendants create a form and as the pendants are picked off the form fades away. The installation connects intent and process through a cont through a chcourages illows and and ins an absence of threshold improving receptiveness between form and audience.

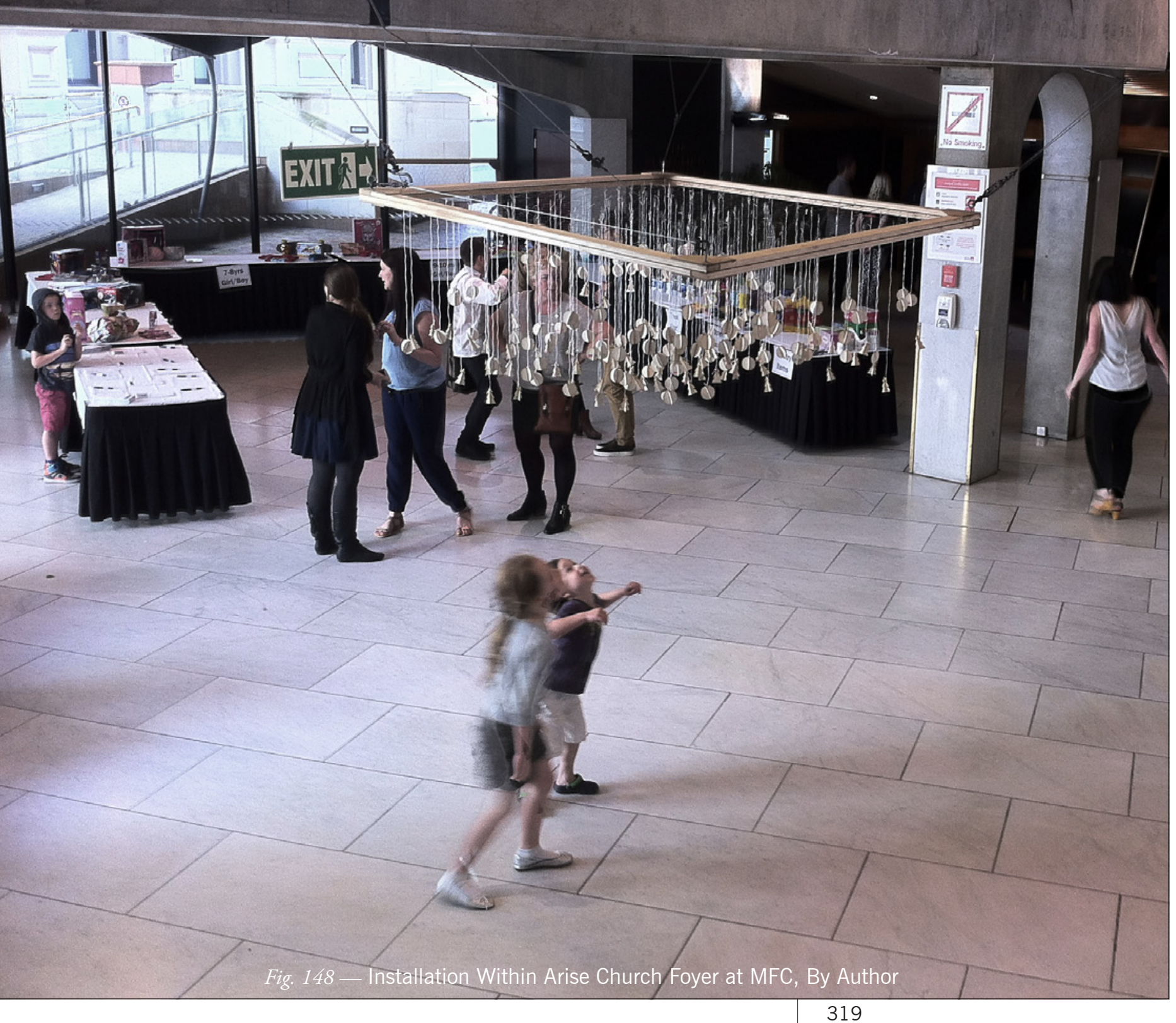





\section{FINAL DESIGN}





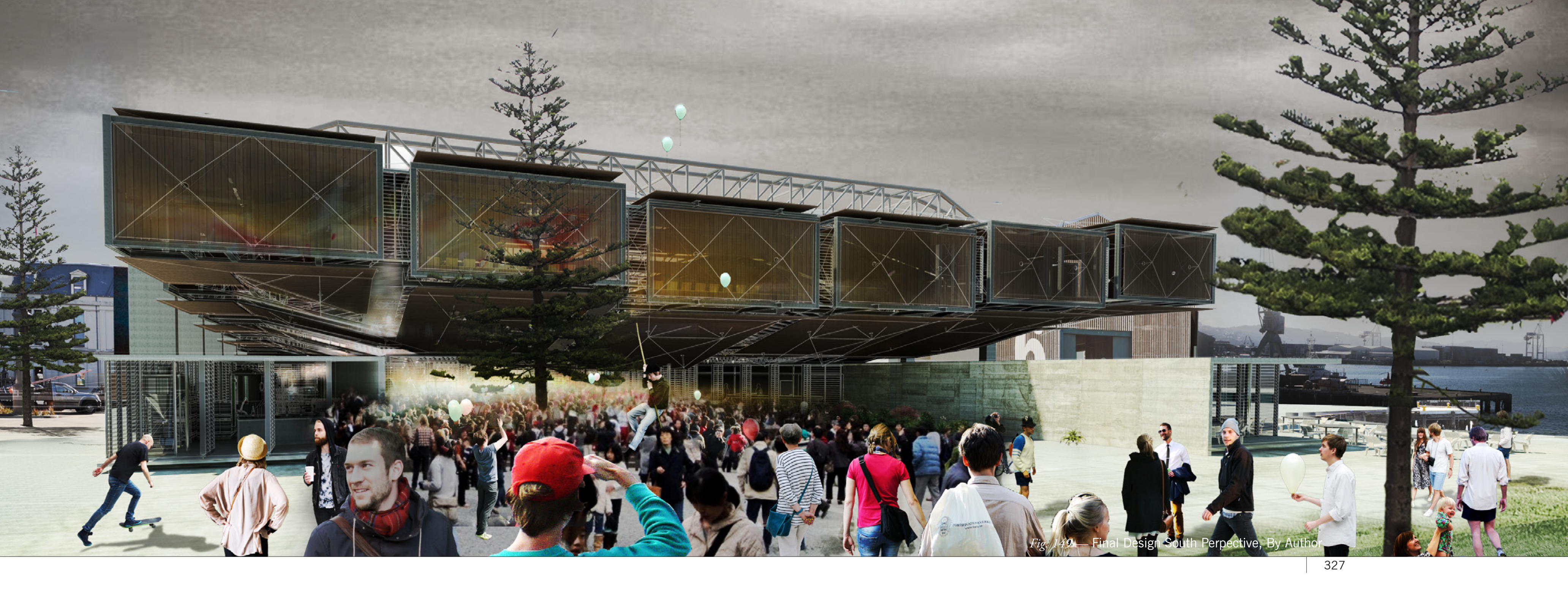




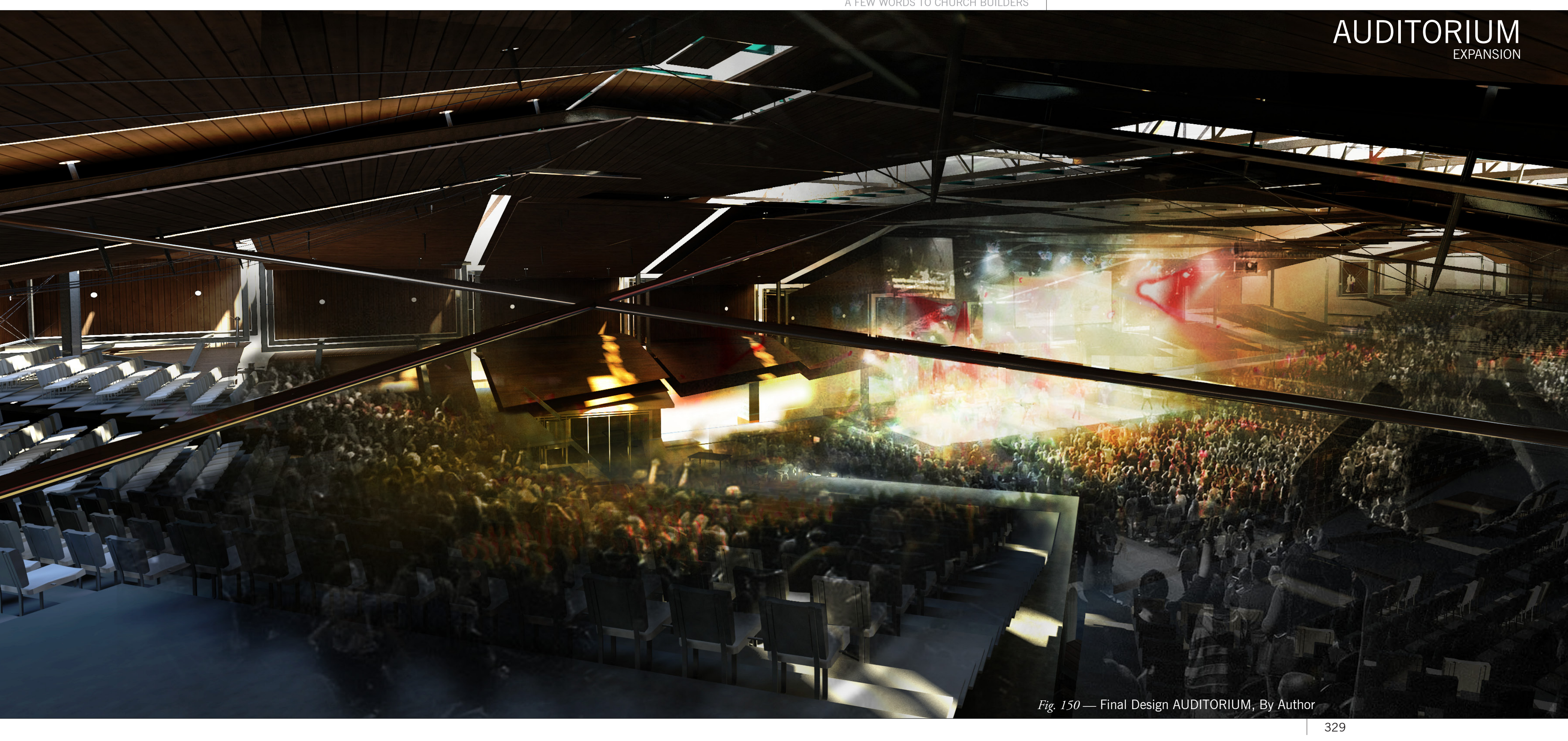


The external focus found within Christianity is currently restricted by architecture that insists on enclosing the CHURCH event. This enclosure is evident in both the rented venues used by ARISE and traditional ecclesiastical typologies. The thesis focuses the investigation around threshold, the junction between the Church (sacred) ARSE CHunCH exist to she the gospel with all but place priority on non-Christians. This priority held by the CHURCH manifests an external ecclesiastical architecture. Design permeates the Church envelope, allowing people contact with the CHURCH and ultimately Jesus.

Through the design led process 'threshold' sought to the include he secul in in the sacted. Early investigations extracted architectura notions from the inhabitants and programme drivers, ARISE $\mathrm{CHURCH}$
These notions included release and eflux, and an attentiveness toward he secular. These informed design iterations, through which ideas were tested and redirected.

The final design, the product of this thesis (figs. 149-176) presents threshold developed in response the the

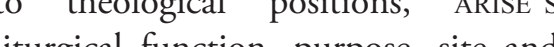
liturgical function, purpose, site and grow. The architectual proposition manifests a secular and sacred overlap communicated through macro to micro scales, from programme to form, envelope and materiality. When it comes to applying this research to other CHURCHES on other sites this thesis suggests an intervention specific to their site and community.

Fig. 149 illustrates the form and envelope of thi The proposion, per six combing secular formal dialogue. The sacred form (blanket) floats over the concrete pavilions housing secular programmes brewery (left) and restaurant (right). The Church form lifts up to allow the insertion of the secular.

The forms housing the secular programmes are represented by a concrete envelope while the Church is dressed in the slatted wood. The Church materiat allows wood. The Church in the shised wood This allows shadows and the light within to be translated externally, these notions are clearly represented in the perspective. The combined effect of form, envelope, materiality and programme in this image creates a receptive entrance seen here releasing light and atmosphere outside.

Within the existing TSB Arena's me sits the architectural intervention. Structure is also used as a tool to communicate the design intent, the Church structure is externally braced with tension ties; A) to allow slender lengthy spans, B) to metaphorically communicate an externalised СHURCH.

Fig. 150 shows the auditorium at full capacity; designed to house 50006000 people the auditorium doubles the size of the TSB Arena's auditorium foor space. The crowd is not limited by envelope, yet a sense of encloser till exists. This is a place of comfort and security to the congregation while welcoming to strangers.

Figs. 151-152 contextualise the investigation around the The TSB Arena demonstrating a response to site as well as theological context. Informed buy earlier investigations the site offers social and cultural contexts in which to apply theological motives.

Fig. 153 is the ground plan of final design communicating in detail the secular and sacred threshold. 

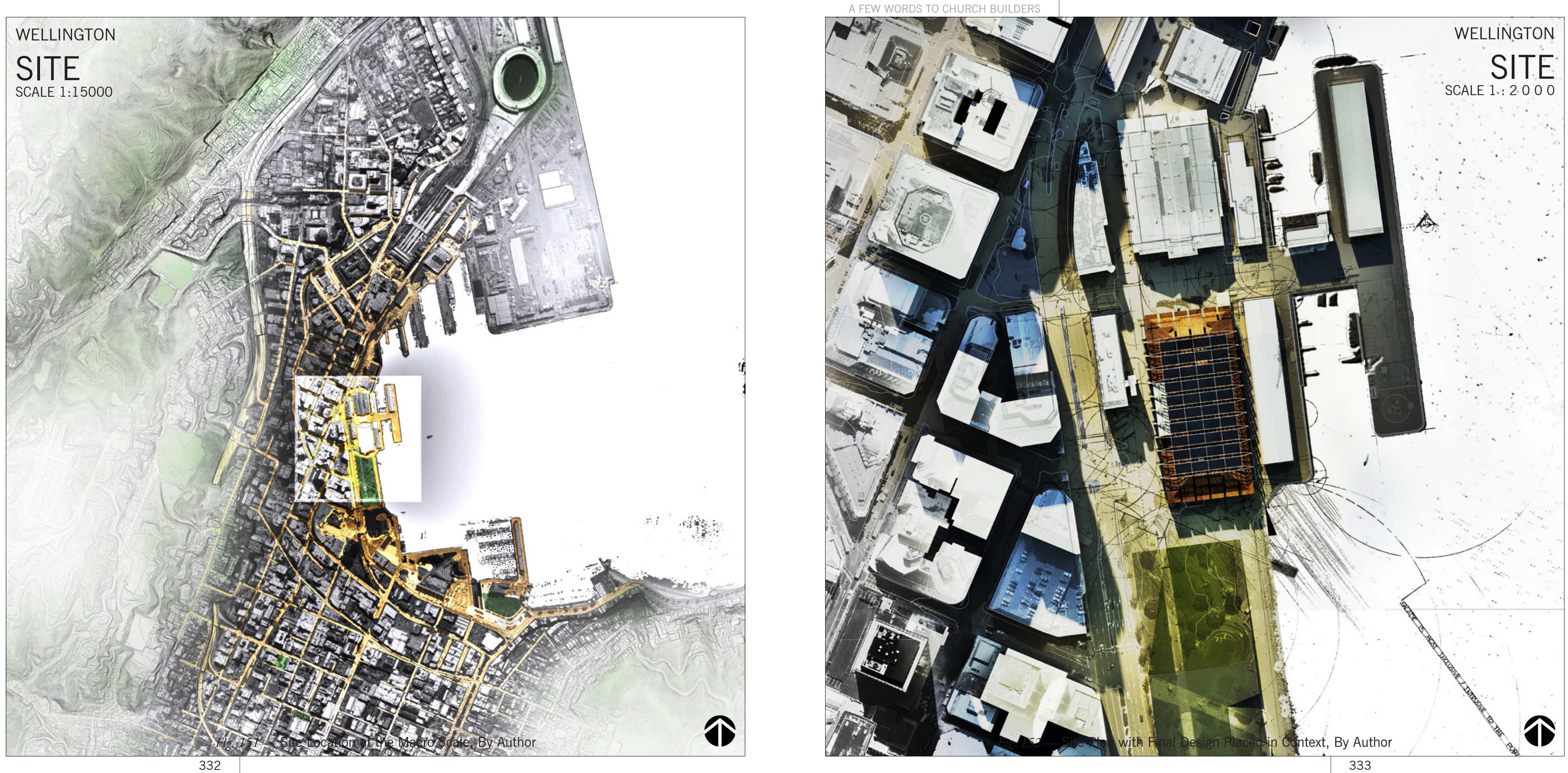


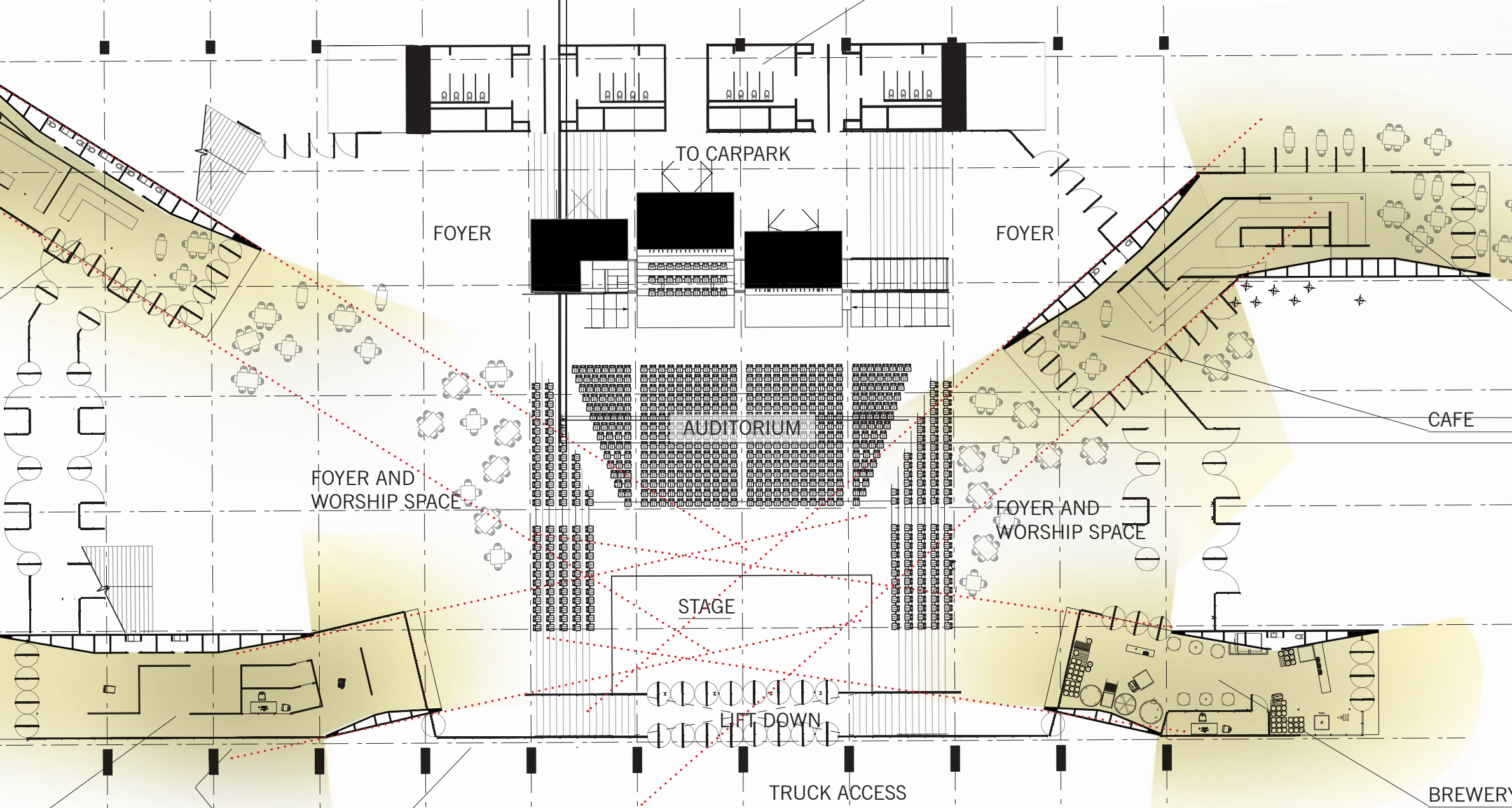





\section{INTENT}
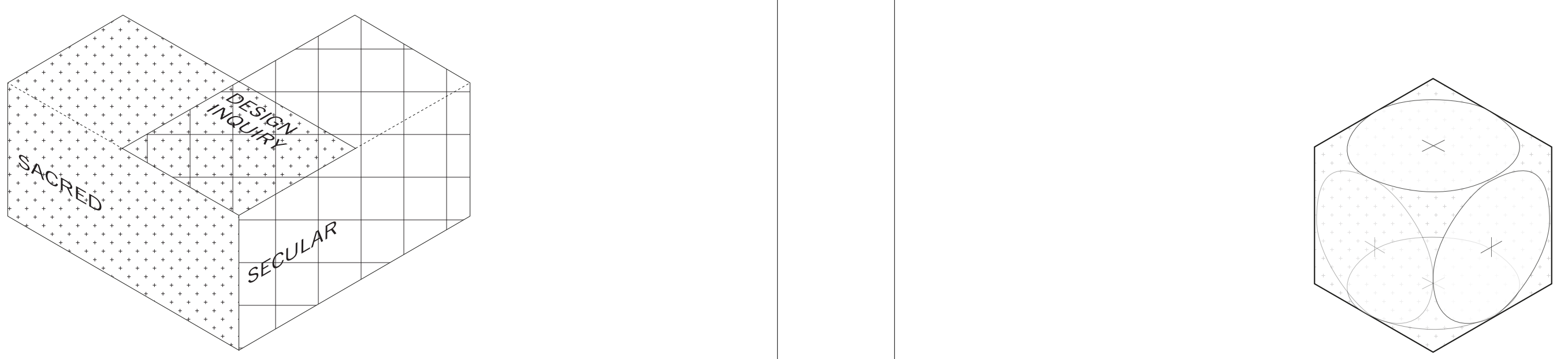

PROGRAM

FORM

ENVELOPE

MATERIALITY 
Final design inserts secular programme through the Church promotes Sovik's into the church as a tool to blur the wish for the Church building to not typically strict secular and sacred only provide for its own needs, but for threshold often associated with the needs of the community. ${ }^{1}$

ecclesiastical architecture and traditional Christian religious practice. The Pentecostal снURCH is often required the Church framework Typically operated within a theatre themselves from the them separion is to which to whe insents to to externally. The insertion of secular those who are not aware of what this programme implies secular and sacred Church holds, this closed off building ownership within the Church both is not inviting. The insertion of secular activating the site beyond Sundays and programme provides people unfamiliar providing an interactive platform to with the CHURCH both a sense of blur the secular and sacred threshold. familiarity and affirmation that they

insertions link the Church with

the surrounding uran nith

Restauts as expork.

Restaun's as exp uned 'socular site

inserion' line the watefont, while

galleries and museums run behind.

The continuation of existing networks

1.Sovik, Edward. 1973. pg 39

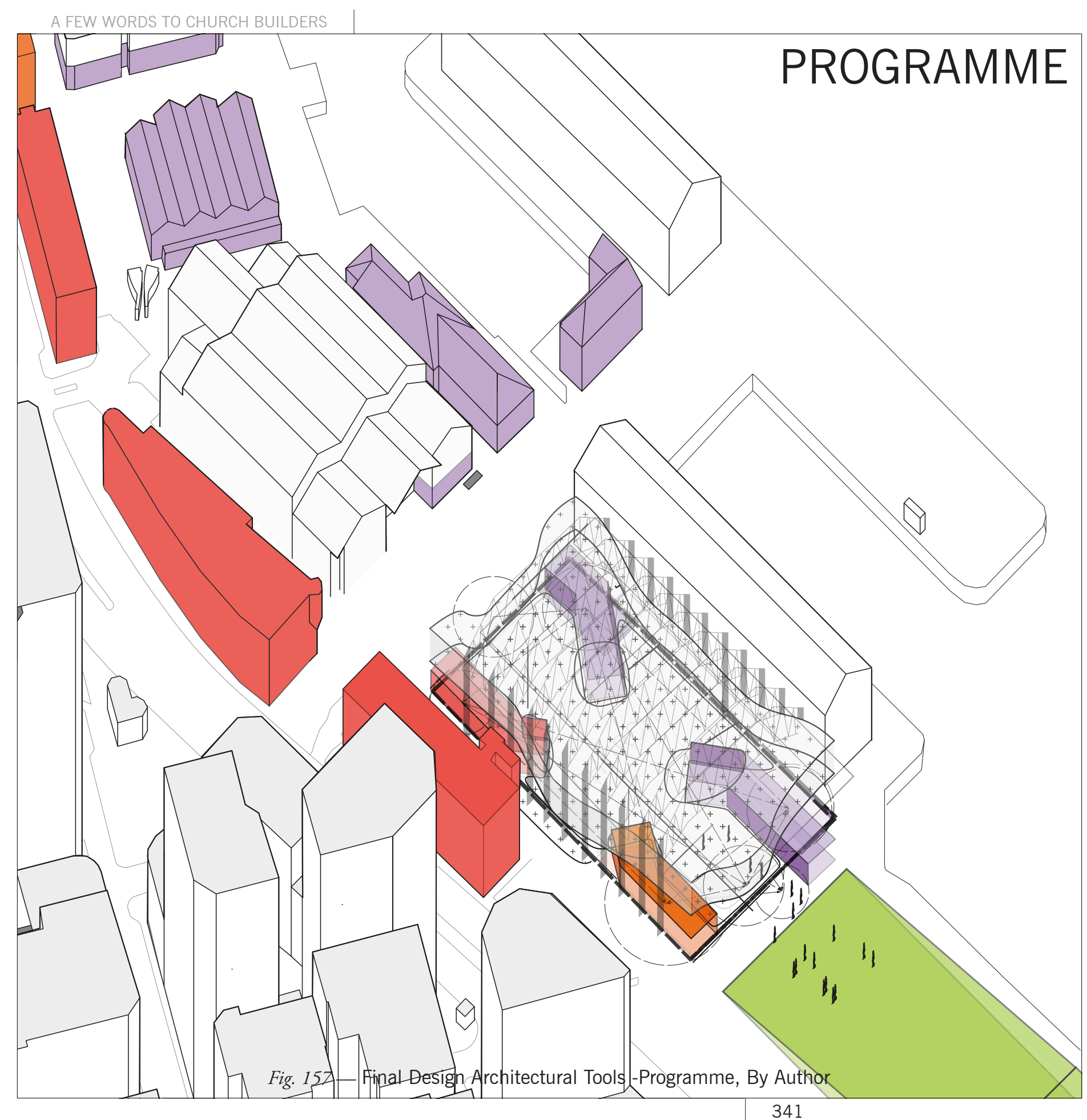


Form is used as a tool to communicate ablur of the secular and sacred.

Secular insertion provides the design with two architectural entities; the secular pavilion and the sacred form, referred to as 'blanket.' The two forms enable an architectural dialogue which communicate the inclusion of the secular within the Church.

The secular programmes shown in plan (fig. 153), enters the Church parallel with the existing urban grain, tral focal point internally; the stage. In plan, the two main structural walls of the secular programmes direct the internal spaces outlook, discussed in this context as attention. The south restaurant pavilion looks out upon the wate but once inside the a second structural concret second structural concrete wall turn and stage.

1.Sovik, Edward. 1973. pg 39
The secular programme in the Church provides a forum in which to communicate the CHURCH's attitude toward the secular. The Church form sits like a blanket overtop the programme and site, lifted up where there is a secular insertion (Fig 170). These two forms do not touch, formally communicating no restriction of the secular inclusion within the church. This 'threshold' illustrates a 'come as you are' stance on behalf of the CHURCH.

The undulation of the 'blanket' expresses movement, a notion representative of ARISE, drawn from early design experiments. Movement disassociates encounter with place, object or thing. The form does not seek to represent God through or immence, but is pencounter in the secular, allowing meet God for themselves. 
Envelope is often defined by a human scale to the envelope. This containment. This design uses the provides an opportunity for materiality envelope as a release; a tool to delimit to engage people in the space.

the secular from the sacred and the sacred from the secular, blurring The steel structure is braced by external 'threshold' through an internal external tensional struts, while the porous dialogue.

The thesis investigation directs an reveals some of the interior elements. envelope's porosity internal / external, sacred / secular Church to release and receive light, dialogue. This final design uses sound and people; an efflux through envelope to establish an external envelope informs the secular of $\mathrm{CHURCH}$ focused $\mathrm{CHURCH}$, archived through an inhabitation. The designed envelope inclusion of the secular and a porosity composition affirms an externalising of the Church envelope. This develops of the CHURCH.

a dialogue between the secular environment and the $\mathrm{CHURCH}$.

The secular envelopes are made of concrete and glass. The concrete's Fig. 159 illustrates the Church's impermeability aids in communicating envelope. This module is repeated the sacred and secular dialogue, to make form. The envelope follows expressed through the secular forms the auditorium rake, copmunicating expressed hrough the secular forms the change in angle. Glazed at each end, its interioity to the associated taper allows the public brewery in contrast the expectations thoroughfare at close proximity to of restaurant dining do not lend the space of worship while applying themselves to this exposure.

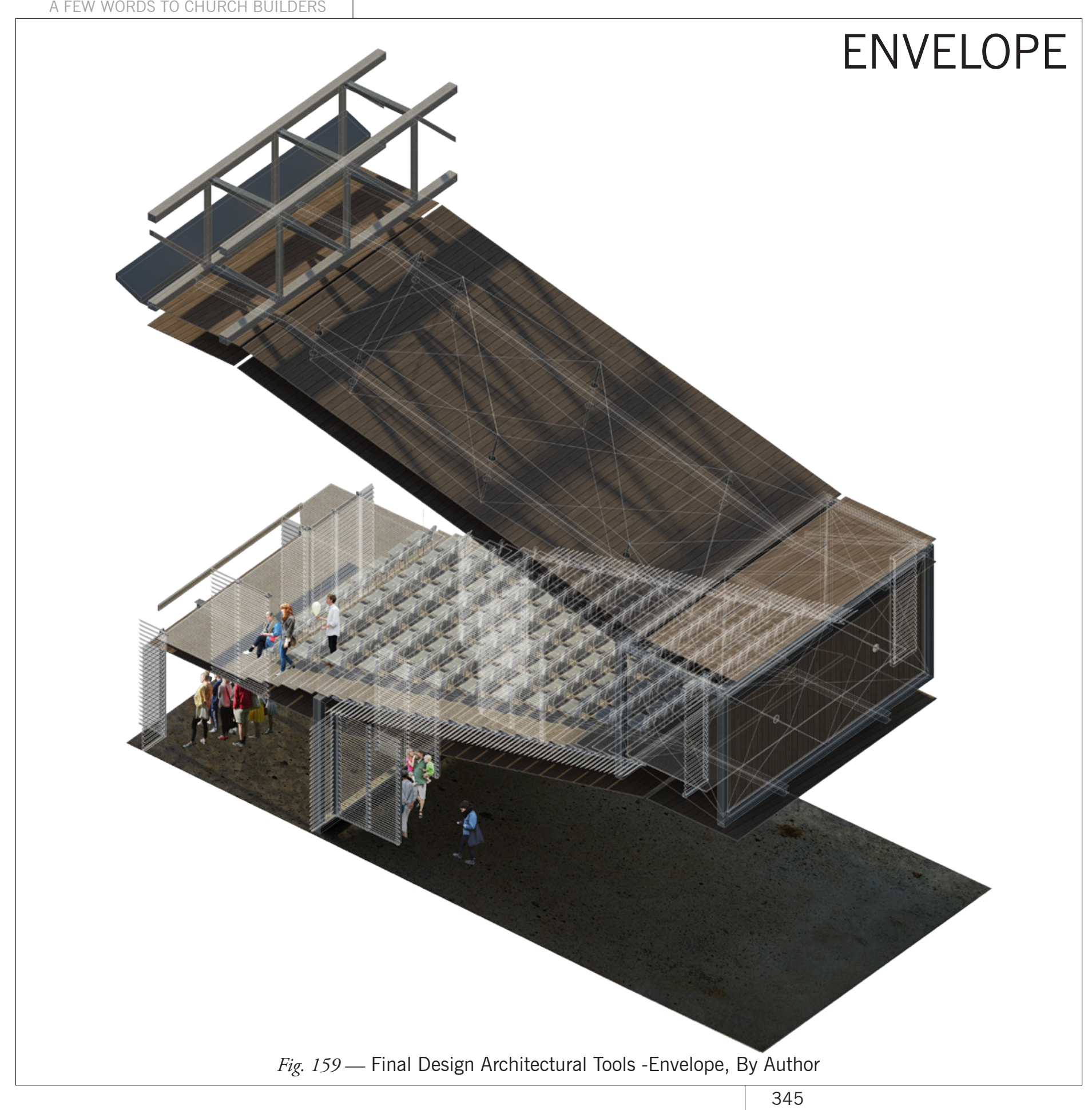


Materiality is used as a tool to affirm resulting trough in the form creates the design intent expressed through intimacy as materiality is able to be programme, form and envelope to touched.

communicate a blurred secular and sacred threshold at macro and micro scales.

The Church's interior and exterior faces are cladded with slatted wood. This consistency in materiality limits the contrast between the space of worship and the secular world to help wifl Robinsonis desire to see worship fulfil Robinson's desire to see worship indistinct to sacred or secular place.

The concrete pavilions housing secular programme contrast with the Church's wooden envelope. This material use visually defines and enables a clear dialogue between the two entities showing the secular and sacred integration.

Form and envelope allow the Church form to sweep down where there is absence of secular programme, the
The term externalise eludes to making what is internal external, in this case the Church. The continuation of spaces minimises the contrast around threshold. The rough sawn timber cher marks to provide a trace; the wood mevels its own incepion. howing itself off is represtis act of he cin isen's exter is fopts, she of The This nature of reveal is intimate, the materials are selected to be identifiable, engaging the senses rather than solely representational. material from external to internal the church's external focus, showing

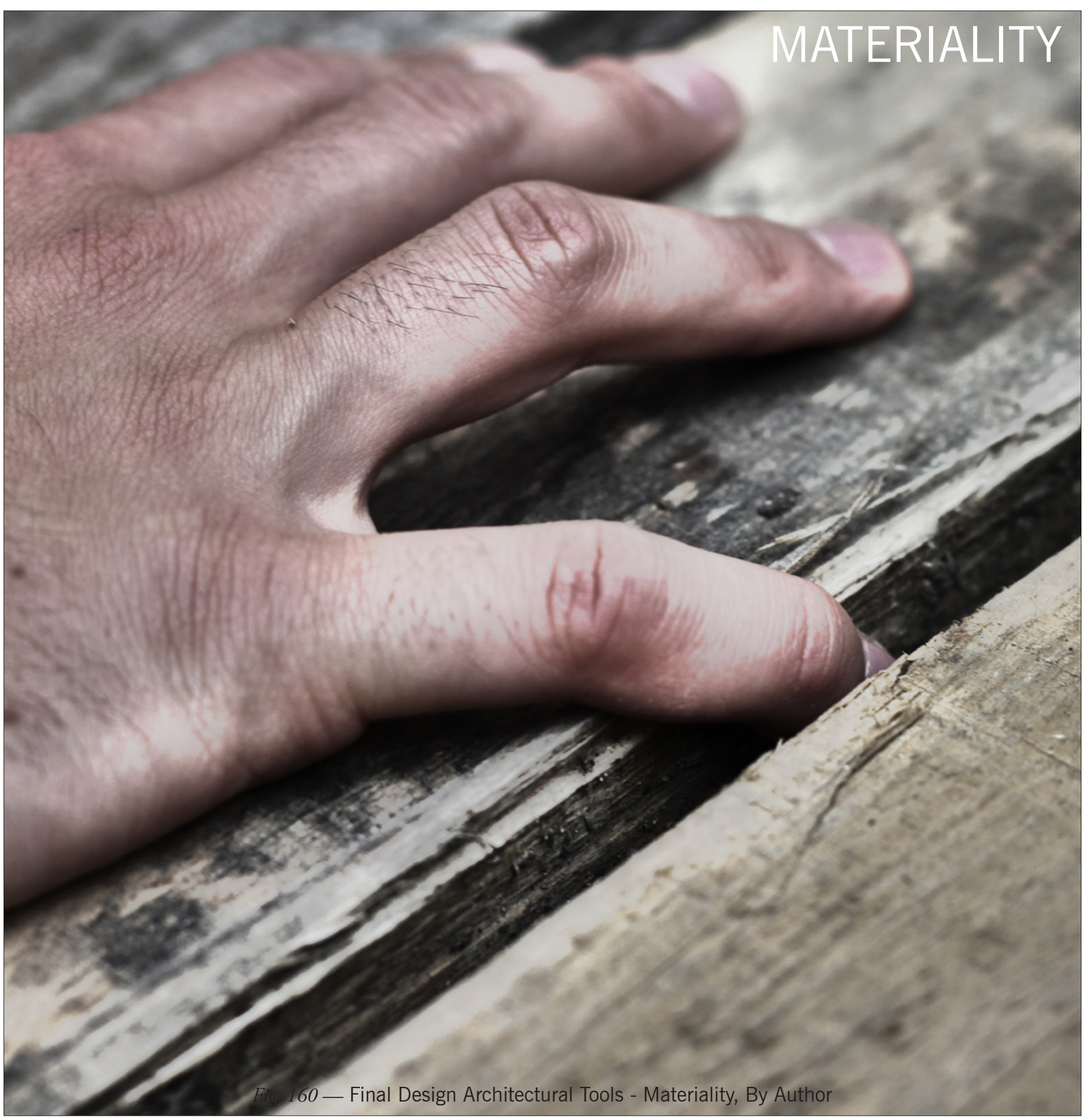


Fig. 161 illustrates the Church in congregation to feel comfortable in the sectional perspective. The forms auditorium capable of seating 5000+ undulations are seen as responding people.

to secular insertions and a permeable

ground floor. The elevation at each Fig. 163 is a transverse section looking end of the Church form encourages south which highlights the horizontal permeability at ground level to both relationships between the worship pedestrians and the secular pavilions. space and the public space. Beyond The threshold seen in section is open the section cut the concrete pavilions in se hat not in a way that are sen auditoring secular envelope modules are dictated by the
ene Fig. 161 in conjunction with Fig. auditorium balconies.

162 illustrate the expansion and contraction experienced in the The stage, the central focal point of auditorium. Seen in the perspectives the auditorium, sits on the west wall. and accompanying diagrams, ceiling The semi permeable west wall releases panels are raised or lowered altering light from the stage to the road. This the space to suit the congregation. placement of stage allows an indirect The accompanying diagram explains approach into the Church from by lowering the roof, the auditorius the north and south The ground low the ground spatia attent is fown into while also min when passing through the threshold. a continual rake over the existing This enables the current 2000 strong amenities to the east wall.

SACRED AND SECULAR 



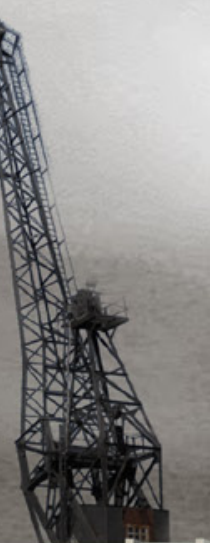

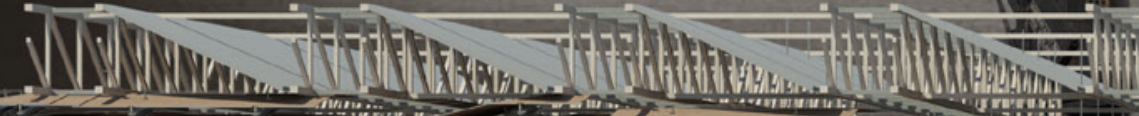

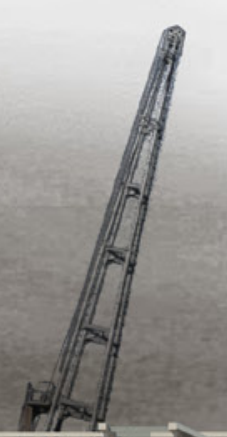

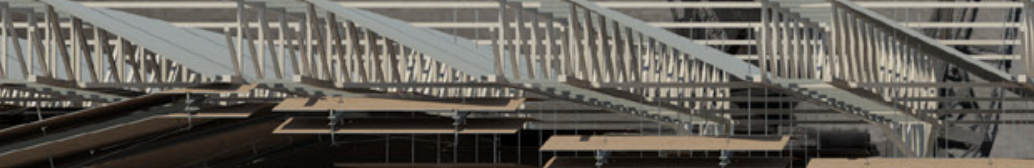

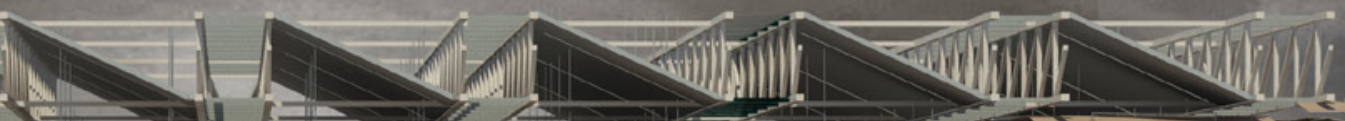

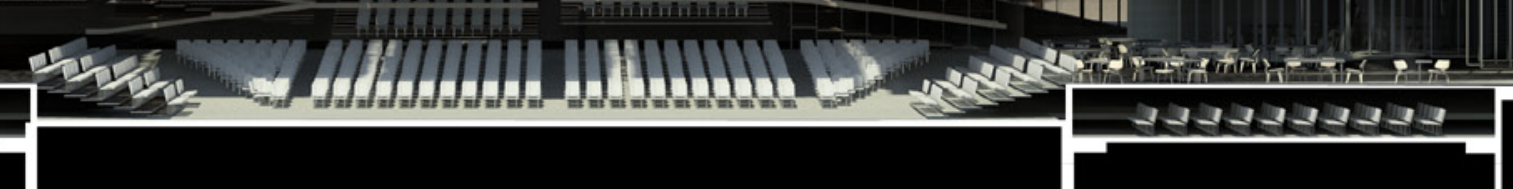




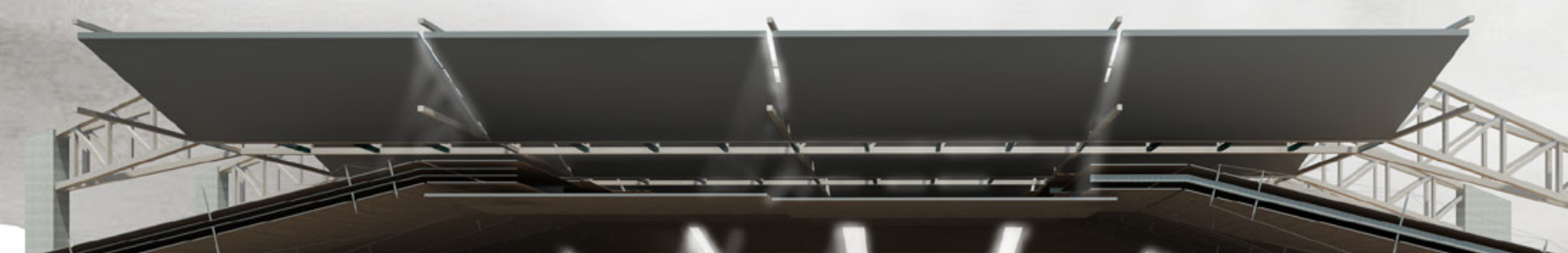


CHURCH+CAFE /RESTAURANT 
The following images illustrate the restaurant's insertion with the Church.

Fig. 164 describes in plan and section the insertion of the restaurant programme into the church. The restaurant exists as a freestanding yet visually inclusive element, with a small passage to link it to the cafe which is imbedded in the Church. The cafe is directed toward the stage and the space directed towad he stage and the space is able to be used as an extension of churches foyer or auditorim.

Fig. 165 Illustrates the intersection between the church and the concrete pavilion housing the secular programme. The dialogue created between this embrace of architectural forms manifests the theologically directed acceptance of the secular in the so called sacred. The Church form Church form does not pavilion, this vistally demonstrates the secular Ju the sacred and vice versa. The Junction between the two entities is glazed to allow light to filer out or in highlighting the gap. The cafe imbedded into the Church is intended to be used as foyer and worship space.

Fig. 166 illustrates the cafe imbedded into the Church foyer and auditorium. The cafe and the foyer's inclusion in the auditorium breaks any clear lineation etween the programmes. When fully then fully the seging auditorium seating and foyer seating. Design fosters an organic progression from the daily life to the CHURCH service, this is achieved with the merging of the secular and sacred.

Fig. 167 a view from the cafe into the church. The image graphically the Church environment coexisting in the cafe.

Fig. 168 illustrates the secular insertion in the Church, existing separate from, but included in the Church event.
OUTSIDE

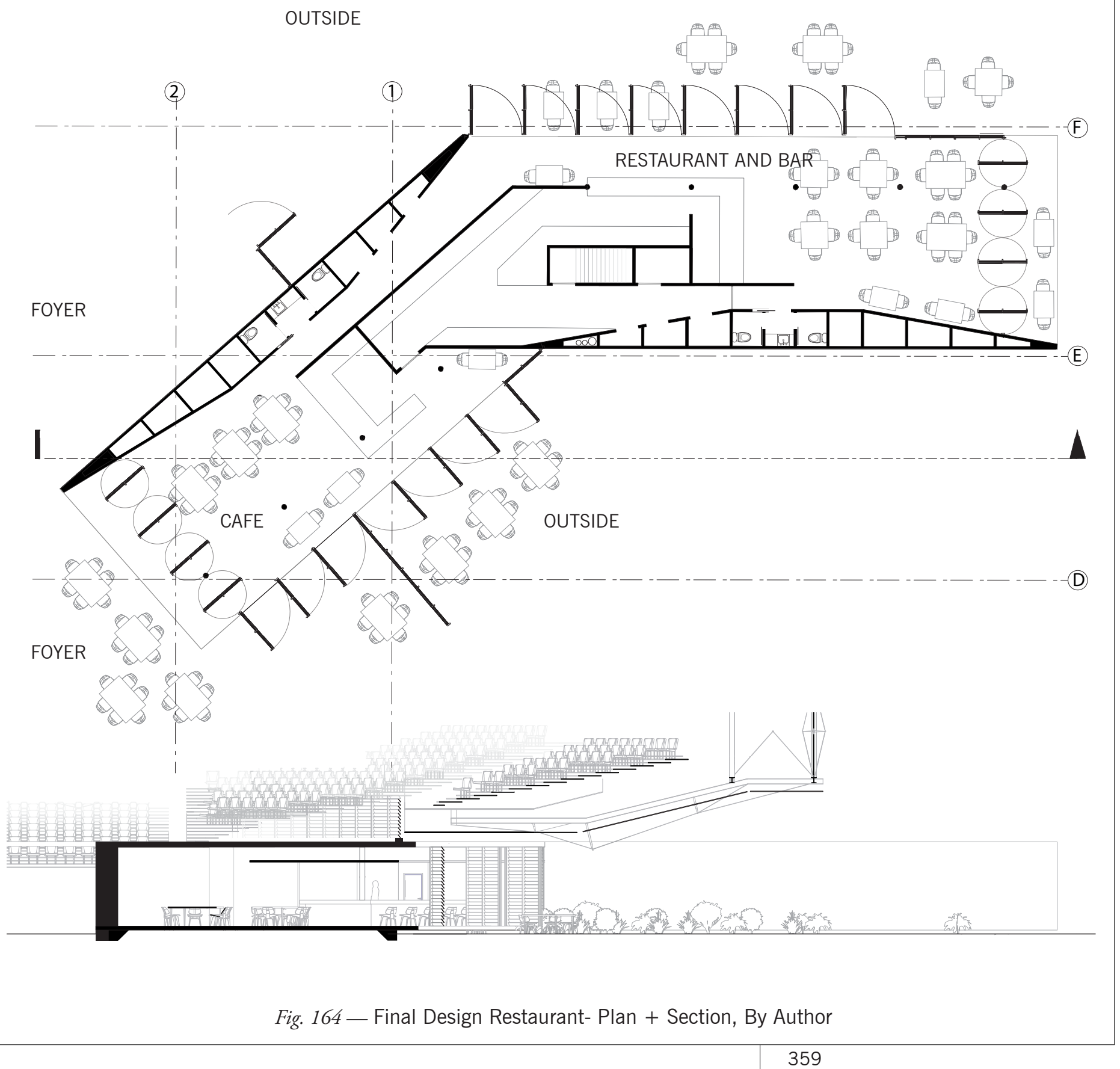




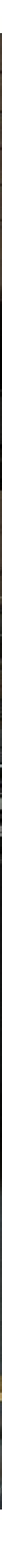




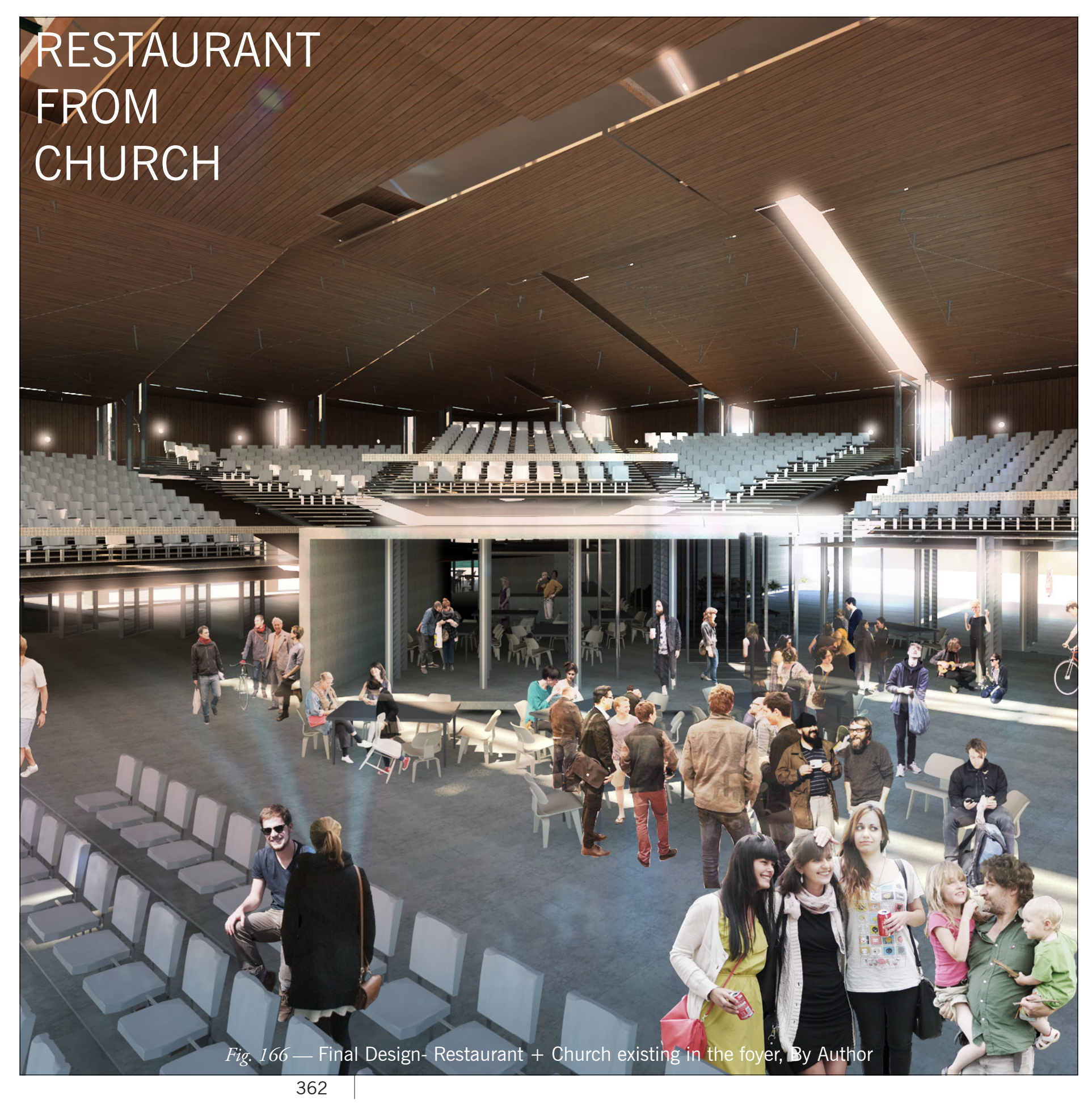
FROM CAFE

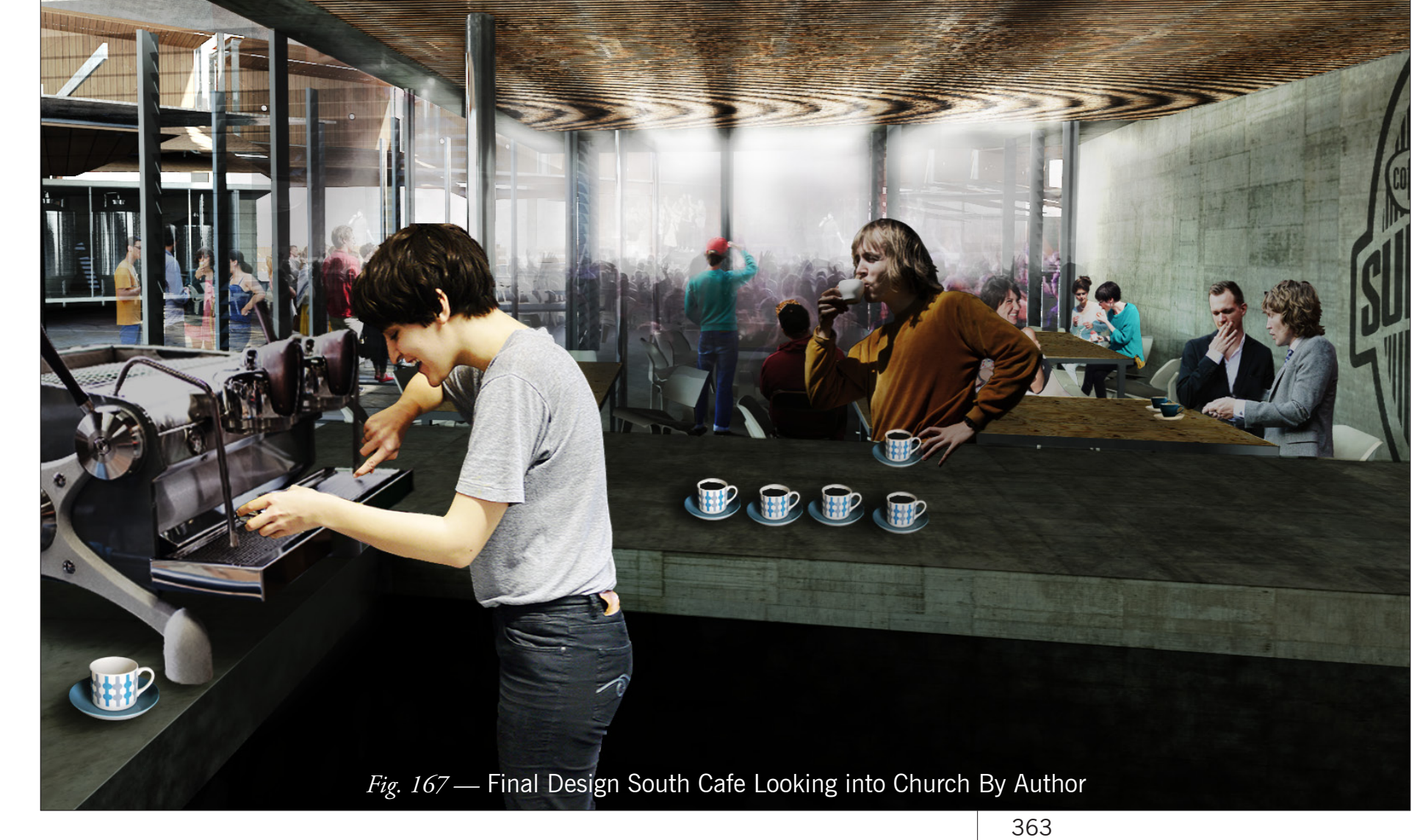




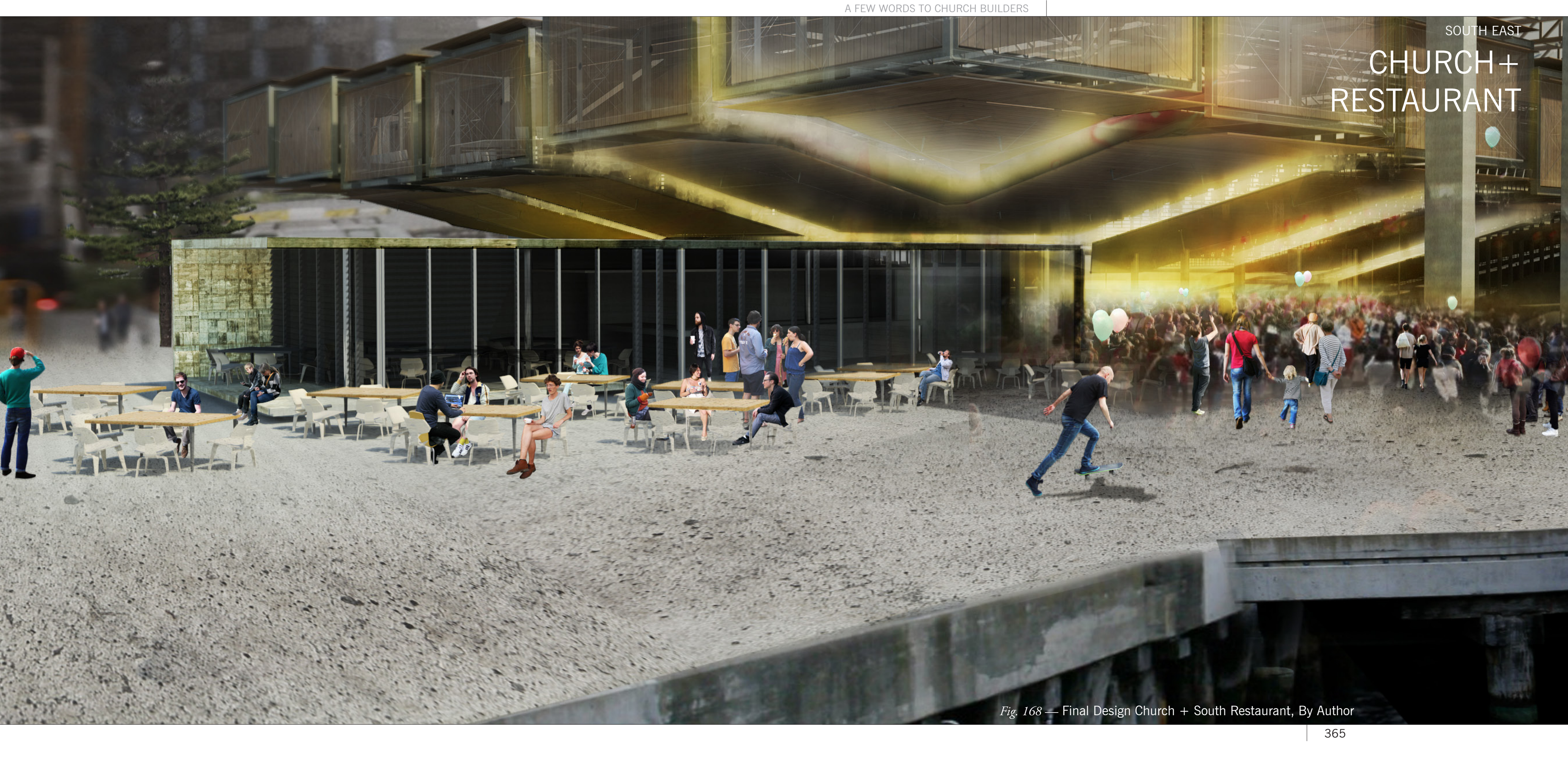


$\mathrm{CHURCH}+$

BREWERY 
BREWERY

The brewery programme challenges the Church in its acceptance of the secular The existence of this programme within the Church clearly states the acceptance of the secular in the sacred.

It is intended that the brewery will operate similar to the local Wellington brewery 'Garage Project' which sells beer but does not hold a liquor licence. This allows the presence of he bence. This allows the prew in the church without the sense of corruption. There is still a degree of threshold to be maintained to ensure the safety of the people within the church, The architecture portrays a passive relationship between the
secular and sacred inclusion of one another.

Fig. 170 visually illustrates the location of the brewery under the Church, either is not restrict functioning flly. The image shows or leak of light from the CHURCH upon the wall of the brewery continuing the

discussion of the secular and sacred.

Fig. 171 illustrates the dialogue between the Church form and the secular. The image looks into the Church looking down the brewery wall. The auditorium wall in the foreground sits above, while those beyond the brewery are lowered. The form's glazing provides physical enclosure and shelter from external efflux from the macto to scales.

Fig. 172 illustrates a church service in procession influencing the brewery.

Fig. 173 shows the brewery and restaurant insertion into the church in relation to the immediate surroundings. The space between the brewery seen here is being used for a gane of fooll. building welcomes undesigned uses. 


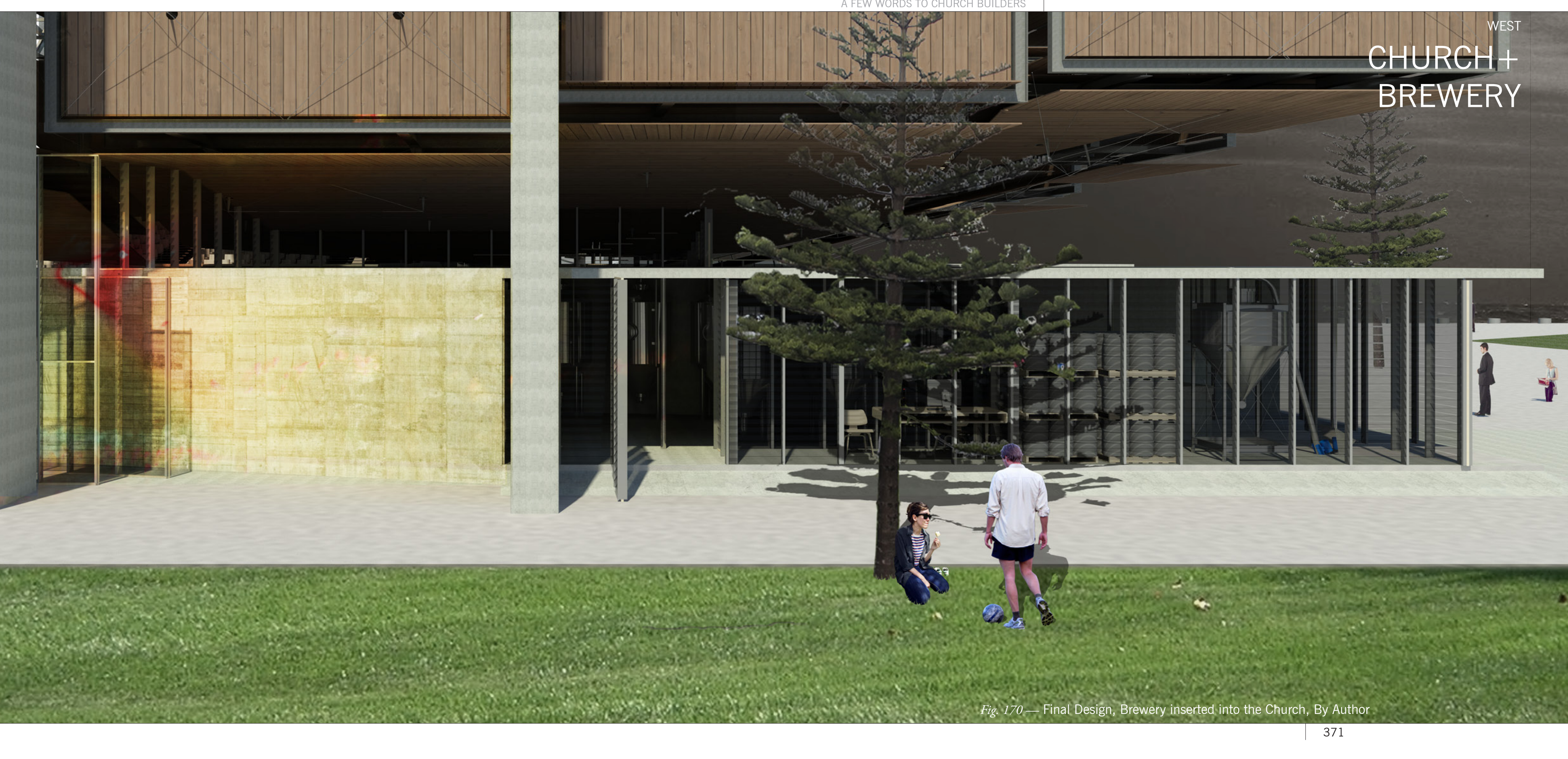




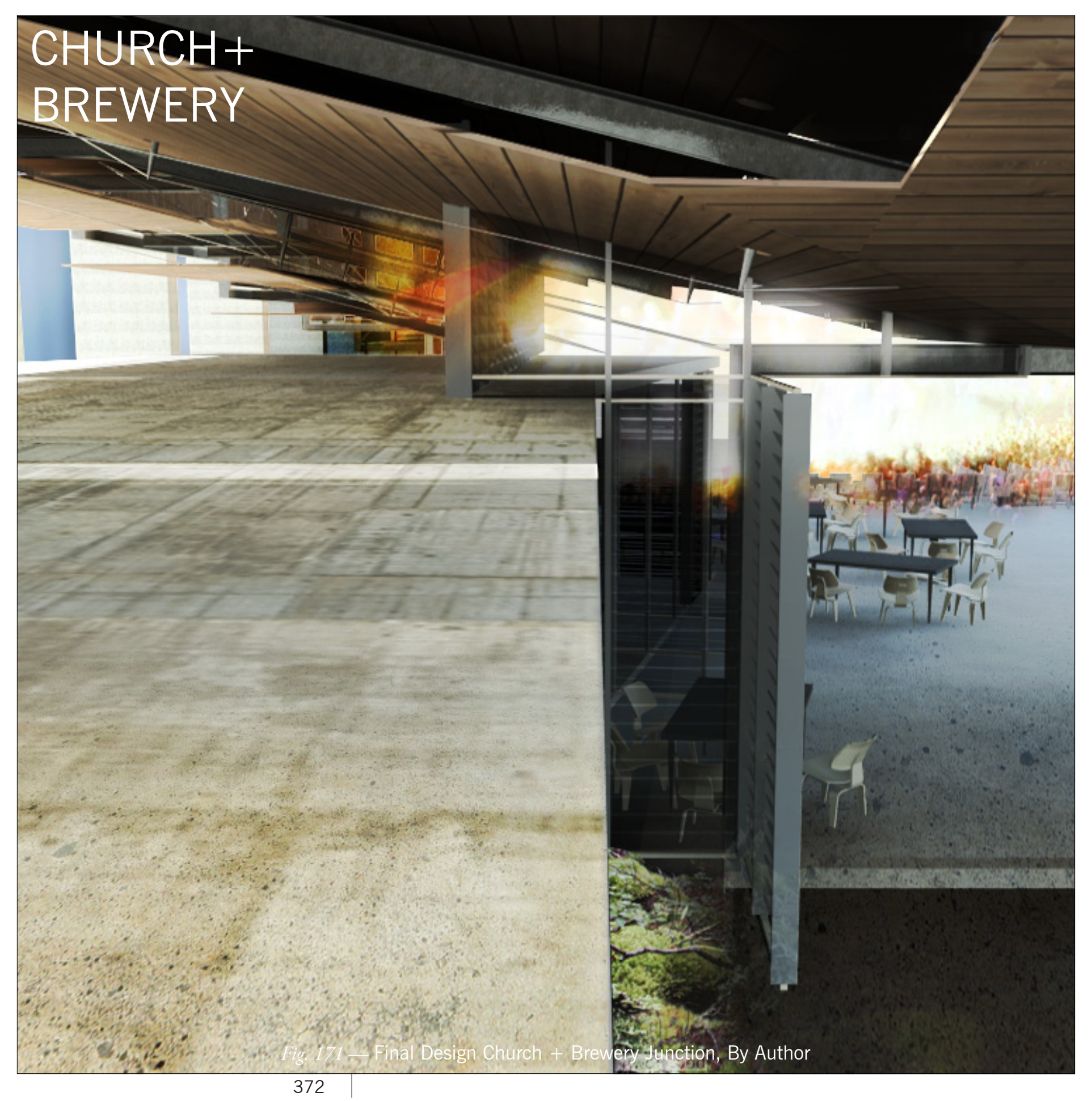

$\mathrm{CHURCH}$ FROM BREW-

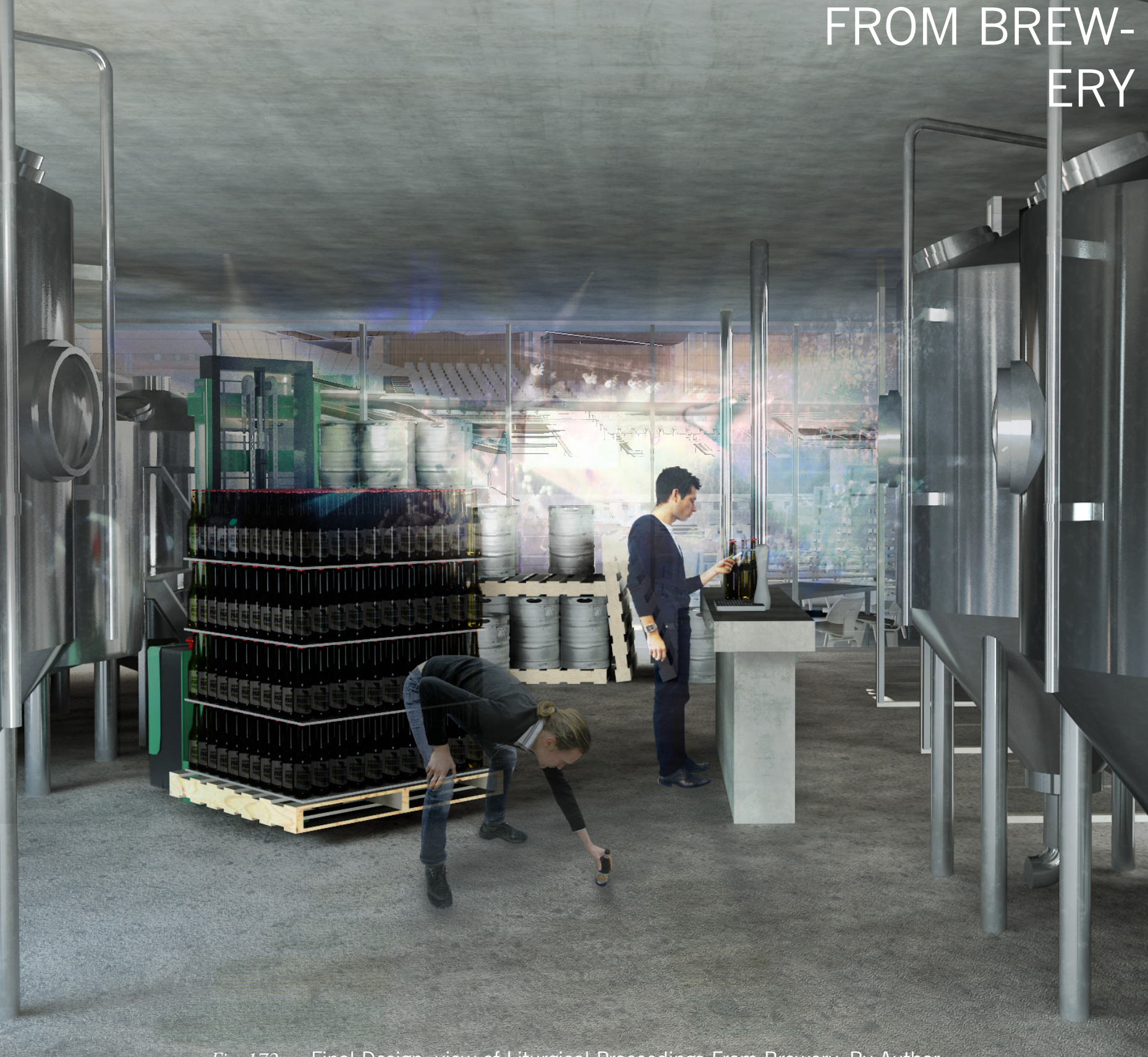

Fie. 172 - Final Design, view of Liturgical Proceedings From Brewery, By Author 


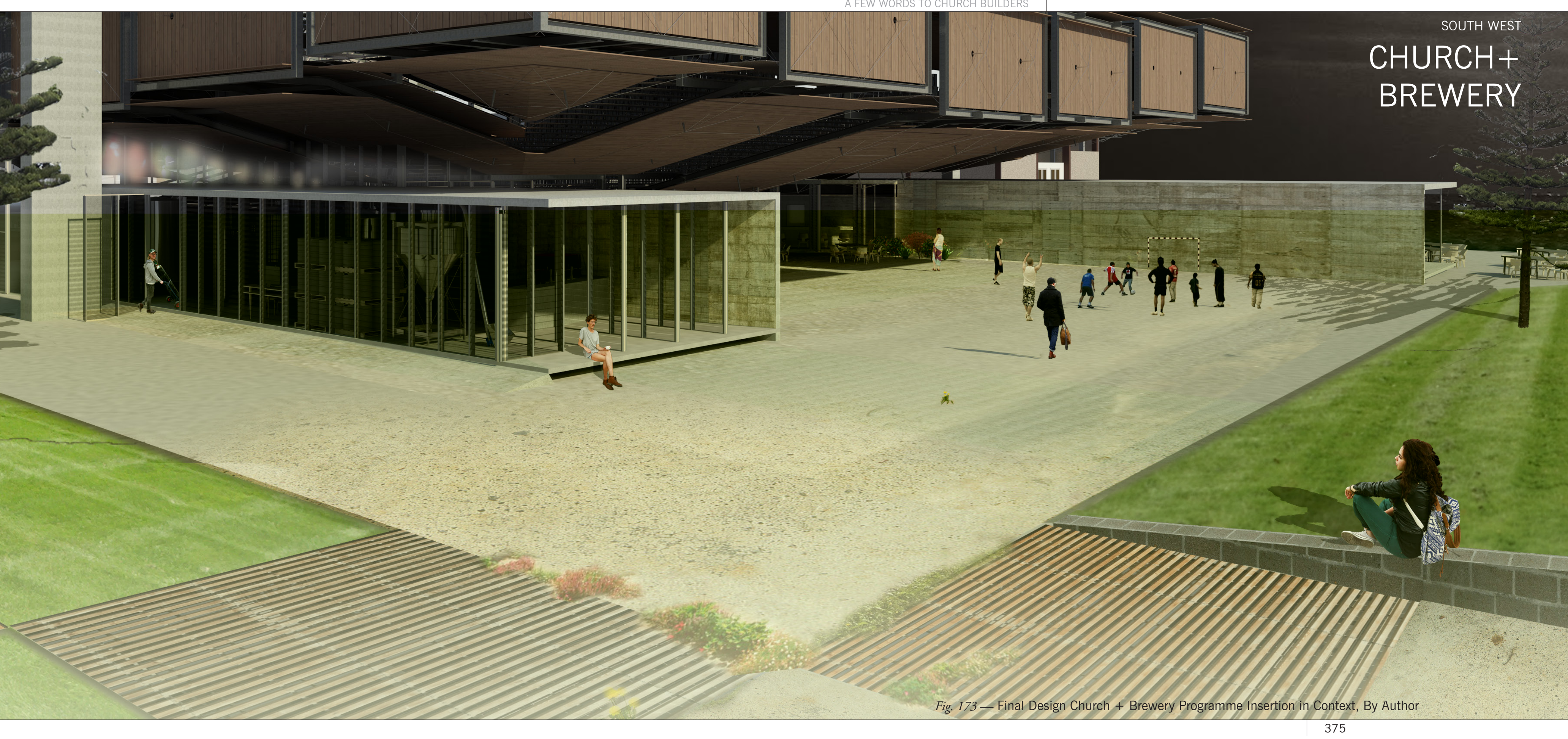


The foyer space defines a physical Fig. 175 illustrates in section the foyer's intersection between the secular and relationship from inside to out. The the sacred. This space delimits both facilitation of the secular within the enclosure and separation between the Church, exists throughout the week. Church and the surrounding world, it This constructed threshold affords is a 'threshold' moment.

Fig. 174, The combination of foyer and auditorium challenges the tendency within Pentecostal churches to separate the foyer and auditorium. The passerby is allowed an immediate understanding of the liturgical operation as he enters the foyer. This space is used as a tool to blur the worship space. This release the Church into the public realm worships dependency is not placed on a physical separation from the world.

The perspective shows the foyer's position within a single plane of auditorium rake from the ground floo seating to the balcony seating. The pavilion in the immediate foreground the secular an ownership within the Church. This existence breaks down perception of the Church and God as separate or untouchable from the

Fig. 176 shows the auditorium with the ceiling panels down, providing a smaller space more focused on the external surrounding than itself.

To conclude, the design creates an environment representative of theological stances while facilitative

of ARISE and its liturgical programme. The sacred and secular blur creates a passive connection between the two entities.

focuses on the foyer.

FOYER

AUDITORIUM + SECULAR 


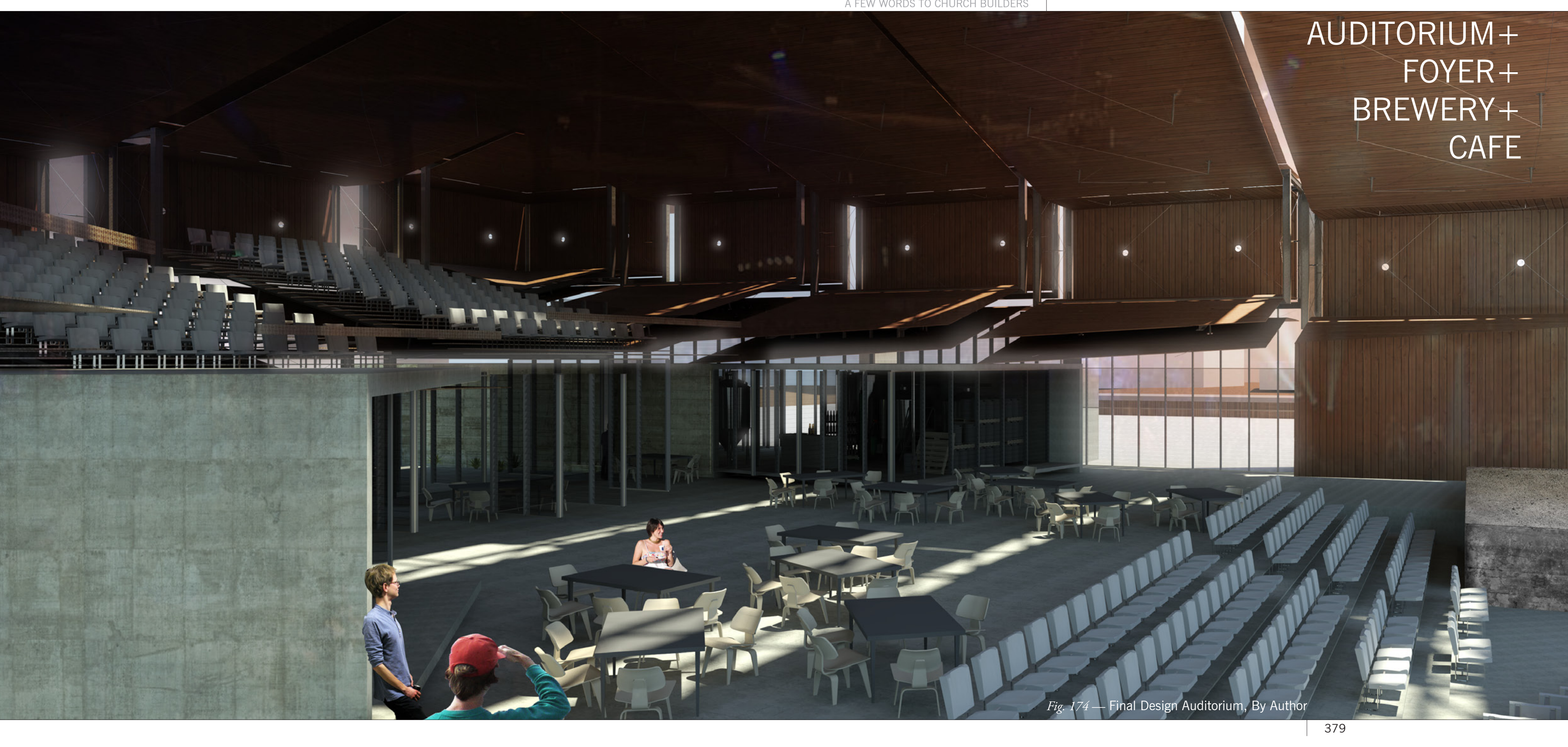




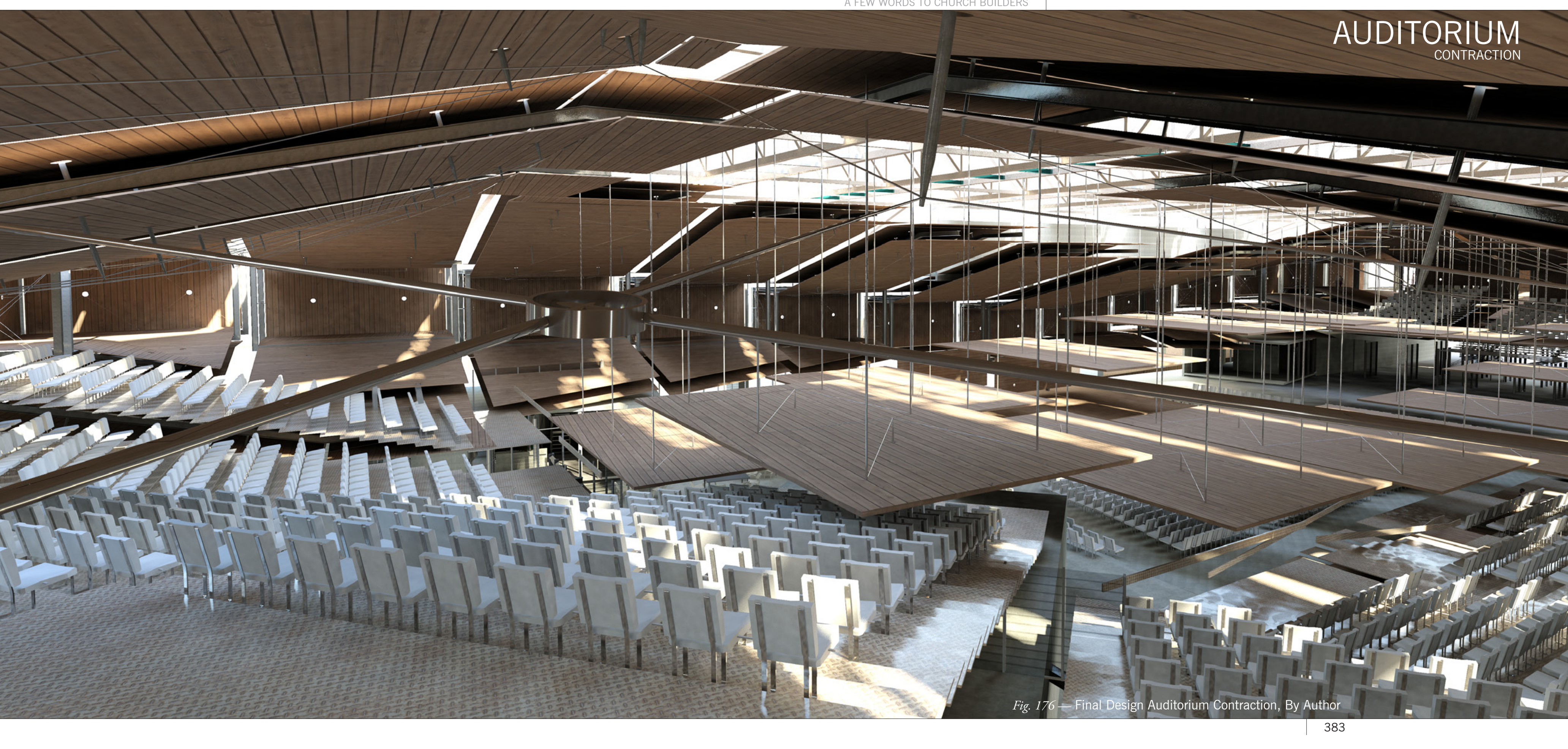




\section{SOUTH WEST \\ PERSPECTIVE}

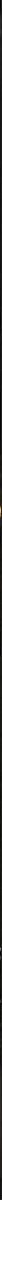



CRITICAL REFLECTION 
The Bible sets a strong precedent for the primary purpose of the CHURCH to share the gospel. This external efflux is rarely portrayed through traditional ecclesiastical architecture, which is
often designed for the comforts of its congregation and their vision of God.

It is argued that architecture can be either a prime aid or hindrance in fulfilling the purpose of the che in fulfing the purpe The thesis idenifes the design of sudden thresholds within many existing Churches. These threshold extract and isolate the CHURCH from the world in order for the congregation to encounter God without outside interference.

ARISE CHURCH currently holds its services in secular theatres which thus inherently interes in secilar heares which This hesis designs the Church around the priorites of the seclur for those the priorities of the secular for hose likely to be hesitant to enter a Church.
The final design is the product of a process testing, developing and responding to criteria outlined in the introductory theological stance. An architecture is developed that is concerned with the secular and sacred relationship, allowing the secular in the sacred, and vice versa. The thesis develops into a finl design that uses programme, form, envelope es prome, form, envelope primary tools ine rich the sacred and secular overlap. The final design, the product of this thesis, concludes with an architecture that convincingly includes the secular in the sacred; the design externalises the Church.

Despite beginning with a clear direction, the thesis reserch process

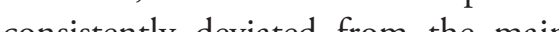
line of inguiry. However he very act of this splintering and positive redirection of subsequent sections. The desired Church evolved through seven design phases, and was subject to constant testing, before an architectural manifestation arose that offers a solution to the sacred and secular divide. By breaking down the Church envelope, the contents are externalised and made approachable to all. The thesis would not have reached the same conclusion if it were not for the accumulating design-led process.

Further research to test the application of the blurred threshold between sacred and secular concept on differen sites or at different scales could reveal further similarities in design solution and processes to complement this research. The thesis contributes to the architectural discipline surrounding ecclesiastical architecture in contemporary way, as a reflection to the modern Pentecostal Anse Churb. The design intent is intended to be applicable to other che be applicable to sharing a similar theological stance and questioning building their own structures. Pentecostal CHURCHES are so often limited to rented or secular structures, in an attempt to engage with the secular, however, if specifically designed an architectural solution can aid the CHURCH in its audience delivery of the gospel.

Just as ARISE CHURCH develops its delivery of the Gospel through music and sermons, so to will the $\mathrm{CHURCH}$ lend itself to an architecture that is as progressive as its delivery. The externalising of the $\mathrm{CHURCH}$ through architecture is a challenging and perhaps lofty idea, one which could even cause discomfort amongst congregates. But there is a place for a dialogue between the liturgical operations and the secular This will afford people an understanding of the Church and its intentions, while giving God an opportunity to move beyond the four ralls of the 



\section{LIST OF}

FIGURES

FIGURE 1

FIGURE 2

FIGURE 3 .

FIGURE 4.

FIGURE 5

FIGURE 6

FIGURE 7 .

FIGURE 8 .

FIGURE 10 .

FIGURE

FIGURE 12 .

FIGURE 13.

FIGURE 13.

FIGURE 14.

FIGURE 15 .

FIGURE 16.

FIGURE 18

FIGURE 18.

FIGURE 19.

FIGURE 20.

FIGURE 21.

FIGURE 22.

FIGURE 24.

FIGURE 25

FIGURE 26.

FIGURE 27.
LIST OF FIGURES

Photograph Compliments of Arise Church, 44 Wigan St Whotogton, $\mathrm{NZ}$.

nts of Arise Church, 44 Wigan St

Petograph $\mathrm{Comp}$. ington, NZ

By Author

By Autho

By Author

By Author

By Author
By Author

By Author
By Author

By Author

By Author
By Author

By Author
By Author

By Author
By Author

By Author
By Author

By Author
By Author

By Author

By Author

By Author

By Author

By Author

By Author
By Author

By Author

By Author
By Author

By Author
By Author

Bies Tim. 2009. Shadowboxx / Olson Kundig Architects. 


\section{LIST OF FIGURES}

[Photograph online] Available from: http://www.archdaily.$$
\text { [Accessed } 13 \text { March } 2013 \text {. }
$$

FIGURE $28 . \quad$ A-E

A-C Bies, Tim. 2009. Shadowboxx / Olson Kundig Architects.

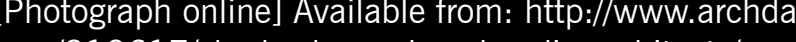
[Accessed 13 March 2013]. [Accessed 13 March 2013 .

年, Chicken Point Cabin by Olson Kundig Architects. [Photograph online] Avai chicken : hoint-cabin-by-olson-kundisarchitects/ [AcCesed 13 ench 2013].

E Benschneider, Benjamin. 2005 Delta Shelter

[Photograph online] Available from: http://www.

olsonkundigarchitects.com/Projects/38/Delta-Shelter 15 March 2013]

FIGURE 29. By, Autho

$$
\text { A-J }
$$

Google Maps screan shot, 11 huttchesons road newtown wellington $n z$ Available from:

B Autor Unknown. Paramount Theatre Wellington.

[Photograph online] Available from: $h t t p: / / w w w . c l a u d i a z i n$ zan.com/? $p=41$ [Accessed 30 March 2013].

C McCredie, Paul. The Embassy Theatre's exterior as viewed from Courtenay Place / Embassy.

[Photograph online] Available from:http://architecturenow. co.nz/articles/embassy/\#img $=6$ [Accessed 30 March

2013].

D Hanger, K. 2008. Opera-House-Wellington. [Photograph

.

\section{LIST OF FIGURES}

online] Available from: http://en.wikipedia.org/wiki/ File:Opera-House-Wellington-2008.JPG [Accessed 30

E Author Unknown.Date Unknown. Amora Hotel Wel lington Photo Gallery [Photograph online] Available from: $\mathrm{http}: / / \mathrm{www}$.wellington.amorahotels.com/gallery-en.html

F Nichols, Lane. 2011. Make it happen: What future do we want for Wellington? [Photograph online] Available from: htp://Wwistuff.co.hz/dominion-post/ comment/

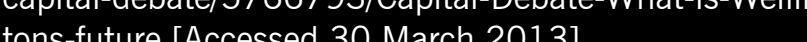

G Staples, Bruce. 2007. St James Theatre Courtenay Place, Wellington, New Zealand [Photograph online]
Available from: http://en wikipedia org/wiki/File:St Available from: http://en.wikipedia.org/wiki/File:St

H Author Unknown. 2010. Lower Hutt Council IPhotograph online] Available from: http://www.voxy co.nz/entertain ment/exhibition-modern architecture-opens-thenew ment/exhibition-modern-architecture-opens-the Author Unknown. Date Unknown. Micheel Fow Centre. [Photograph online] Available from: http:/ www.nzia.co.nz/awards/new-zealand-archiecture -awa Inz-architecture-awards.spx?activeYear $=2011$ \&page $=2$ [Accessed 30 March 2013].

$\mathrm{J} \quad$ Author Unknown. Date Unknown. Entrance to TSB Arena [Photograph online] Available from: http://www uniconxv co.nz/participants/competition/venues/ [Accessed 30

FIGURE 31. March 2013] 


\section{LIST OF FIGURES}

FIGURE 32.

FIGURE 33

FIGURE 34.

FIGURE 35 .

FIGURE 37.

FICURE 38.

A-C

Soo Uk, Chae. 2013. The Sarang Community Church Seoinn Design Group. [Photograph online] Available from: http://www.archdaily.com/413986/the-sarang-com munity-church-seoinn-design-group/ [Accessed 2]

January 2014].

B Author Unknown. Date Unknown. Cobh Cathedra

Drawings for Completion of Spire 1911. [Photograph onlinel Available from: http:/ffoscc com/Exteriorhtml

[Accessed 12 April 2013].

C Author Unknown. 1880s. Christchurch Cathedral in Cathedral Square, Christchurch; 1880s. [Photograph online] Available from: http://commons. wikimedia.org wiki/File:ChristChurch Cathedral, 1880s ipg [Accessed 27 Feburary 2013]

FIGURE 39.

A Underhill, Irving. 1912. The Woolworth Building on July

1, 1912, nearing completion. [Photograph online]

Available from: http:///commons. wikimedia.org/wiki
File: Woolworth_Building_1_July_1912_LC-USZ62

-100109.jpg [Accessed 2 Feburary 2014].

B Photo courtesy of Sellar Development. 2012. The

Shard. [Photograph online] Available from: http://

luxurytravelbeat.com/2012/07/06/offbeat-europes-tallest

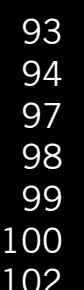

IST OF FIGURES

-building-officially-opened/ [Accessed 6 April 2013].

C Arcspace. 1972. Nakagin Capsule Tower: A Prototype for Today's Micro Houng [Photograph online] Available from: http (ower/ [Accessed 4 March 2013]

$\begin{array}{lll}\text { FIGURE } 40 . & \text { By Autho } \\ \text { FIGURE } 41 . & \text { By Autho }\end{array}$

FIGURE 41. By Autho

FIGURE 43 . B B Autho

FIGURE 44 . B B Author

FIGURE 45- B - By Author

FIGURE 46 . B

FIGURE 47. B.

FIGURE 48. By Autho

FIGURE 49 . B Autho

FIGURE 50

FIGURE 51.

Compliments of Arise Church, 44 Wigan St Wellington, NZ

FIGURE 51

FIGURE 52.

FIGURE 53.

FIGURE 54.

FIGURE 55

FIGURE 56.

FIGURE 58 .

FIGURE 59.

By Author

By Author

By Author
By Author

By Author

By Author

By Author
By Author

By Author

Baan, Iwan. 2011. Dee and Charles Wyly Theatre / REX

Baan, Iwan. 2011. Dee and Charles Wyly Theatre / REX

archdaily.com/37736/dee-and-charles-wyly-theatre-rex-oma/
[Accessed 23 May 2013]

FIGURE 60.
144 
LIST OF FIGURES

from: http://www.archdaily.com/37736/dee-and-charles wyly-theatre-rex-oma/ [Accessed 23 May 2013] 147

REX. 2011. thrust floor plan/ proscenium floor plan /

(het foor

\section{REX. 2011. liberates 20131}

Pformance chamber's perimeter the urban surroundings

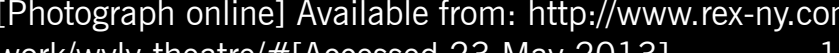

OMA . [Photograph online] Available from: http./Ww

archdaily.com/37736/dee-and-charles-wyly-theatre-rex-oma

[Accessed 23 May 2013]

By Author

FIGURE 64

By Author

By Author

By Author

Photography by Autho

FIGURE 66 .

FIGURE 68

Tom \& Ann McVy Author

Peters Church. [Ph Date Unknown. Willis st, St

$\begin{array}{ll}\text { mcveykiwinews.blogspot.com [Accessed } 4 \text { July 2013] } & 163 \\ \text { By Author } & 164\end{array}$

Bangert, Dennis. 2013 Die Neue Sammlung Schaustelle /

J. Mayer $H$. Architects. [Photograph onlinel Available from: http://www.archdaily.com/420787/schaustelle-j-maver-h-

FIGURE 71

architects/. [Accessed 17 August 2013 ]

FIGURE 72.

$$
\begin{aligned}
& \text { By Author } \\
& \text { By Author }
\end{aligned}
$$

\section{7}

ter

1

a/$$
\begin{aligned}
& 156 \\
& 157 \\
& 158
\end{aligned}
$$$$
\begin{aligned}
& 158 \\
& 160
\end{aligned}
$$

LIST OF FIGURES

FIGURE 74

FIGURE 75.

FIGURE 76 .

FIGURE 77.

FIGURE 78.

FIGURE 79.

FIGURE 80.

FIGURE 82.

By Auther

By Author

By Author
By Author

By Author

By Author

By Author

185

and sports facility. IPhoch For

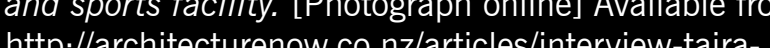

nishizawa/ [Accessed 26 August 2013] 186

of four auditoriums bursts through the glazed facade of this

concert hall in Kristiensand Norway. [Photograph online]

Available from:

performing-arts-centreby-ala-architects/. [Accessed 28

August 2013]

FIGURE 83.

By Author

FIGURE 83.

By Author
By Author

By Author

By Autho
By Autho

NBRS+Partners. Date Unknown. Hillsong City Campus

[Photograph online] Available from: http://www.nbrsap.com.

au/project//hillsong-doody-street-city-campus/ [Accessed 28

November 2013]

NBRS + Partners. Date Unknown. welcoming entry foyer

[Photograph online] Available from: http://www.nbrsap.com.

au/project/hillsong-doody-street-city-campus/ [Accessed 28

NBRS + Partners. Date Unknown. Auditorum

174
175
177
179
181
183
185


186
belly
this
e]
den-
188
195
197
199
200

.
28.
205
.


LIST OF FIGURES

[Photograph online] Available from: http://www.

nbrsap.com.au/project/hillsong-doody-street-city-

campus/ [Accessed 28 November 2013]

FIGURE 90.

NBRS + Partners. Date Unknown. Auditorum + welcoming

entry foyer+ Hillsong City Campus [Photograph

online] Available from: http:/WwW.nbrsap.com.au/project/

hillsong-doody-street-city-campus/ [Accessed 28

FIGURE 91 November 2013]

FIGURE 02 By Autho

FIGURE 93. $\quad$ By Author

FIGURE $94 . \quad$ By Author

FIGURE 95. By Autho

FIGURE 96. By Author

FIGURE 97. By Autho

FIGURE 98. By Autho

FIGURE 100. By Author

FIGURE 100. By Author

FIGURE 101. By Author

FIGURE 103. By Autho

FIGURE 104

FIGURE 105 .

FIGURE 106.

FIGURE 107.

FIGURE 108

FIGURE 109 .

FICURE 110.

FIGURE 111. By Author
207

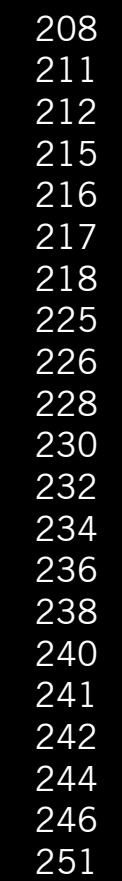

LIST OF FIGURES

FIGURE 112. By Author

FIGURE 113. By Autho

FIGURE 114. By Autho

FIGURE 115. By Author

FIGURE 116. By Author

FIGURE 117. By Autho

FIGURE 118. By Author

FIGURE 119. By Author

FIGURE 120. By Autho

FIGURE 121. By Author

FIGURE 122. By Author

FIGURE 123. By Autho

FFGURE 124. Photograph By Autho

FIGURE 125. By Autho

FIGURE 126. By Autho

FIGURE 127. By Author

FIGURE 128. By Autho

FIGURE 129. By Author

FIGURE 130. By Autho

FIGURE 131. By Autho

FIGURE 133. By Author

FIGURE 133. By Author

FIGURE 134. By Author

FIGURE 136. By Autho

FIGURE 137. By Autho

FIGURE 138. By Author

FIGURE 139

30 [Photograph onlinel Av. St Mary of the Ange/s, Wellington. govt.nz. [Accessed 28 January 2014]

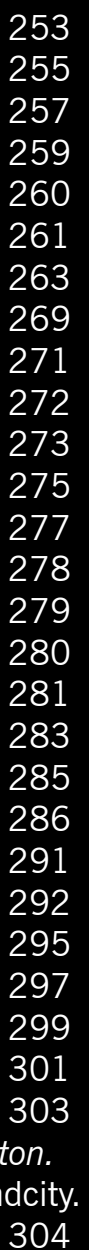


FIGURE 140.

FIGURE 141

By Autho

By Autho

306
307

By Author

307

Technical University, interior [Photograph online] Available

from: hitp://hicarquitectura.com/2013/02/siren-otaniem

chapel-1957/ [Accessed 2 Feburary 2014]

UnKnown Author. Unknown Date. Plans sections and

facade [photograph]. In: Walden, Russel. Finnish Harvest.

Keuruu: Otava Printing Works, 1998. pg. 46

Sterk, Kekki, Kalja, Heikki. 1978. [photograph]. In: Siren,

Tammer-Paino Oy, Tampere pg. 34

FIGURE 146

FIGURE 147.

FIGURE 148.

- 18:40, [Photograph onlin] Available from: http://hillsongnyc.com/node? page $=2$

By Author

By Author

By Author

By Author

By Autho

By Autho

By Author

By Author

By Author

By Author

By Author

By Autho

$\begin{array}{ll}\text { FIGURE 159. } & \text { By Author } \\ \text { FIGURE 160. } & \text { By Author } \\ \text { FIGURE 161. } & \text { By Author }\end{array}$

$\begin{array}{ll}\text { FIGURE 159. } & \text { By Author } \\ \text { FIGURE 160. } & \text { By Author } \\ \text { FIGURE 161. } & \text { By Author }\end{array}$
311

Siren,
Chapel.

314
316
8

0

1
1
3
4
6
19
7

319
327

329
332

333

335
337

338

339
341
343

343
345

345
347
351

$\begin{array}{ll}\text { FIGURE 162. } & \text { By Author } \\ \text { FIGURE 163. } & \text { By Author } \\ \text { FIGURE 164. } & \text { By Author } \\ \text { FIGURE 165. } & \text { By Author } \\ \text { FIGURE 166. } & \text { By Author } \\ \text { FIGURE 167. } & \text { By Author } \\ \text { FIGURE 168. } & \text { By Author } \\ \text { FIGURE 169. } & \text { By Author } \\ \text { FIGURE 170. } & \text { By Author } \\ \text { FIGURE 171. } & \text { By Author } \\ \text { FIGURE 172. } & \text { By Author } \\ \text { FIGURE 173. } & \text { By Author } \\ \text { FIGURE 174. } & \text { By Author } \\ \text { FIGURE 175. } & \text { By Author } \\ \text { FIGURE 176. } & \text { By Author }\end{array}$

353
355
359
361
362
363
365
371
372
373
375
379
381
383
385 


\section{WORKS CITED}

Awan, Nishat, Tatiana Schneider, and Jeremy Till. 2011. Spatial Agency: Other Ways of
Doing Architecture. New York: Routledge Chapman \& Hall.

Bible. International Bible Society. 1973. Holly Bible New International Version. New Jersey: International Bible Society.

Bonhoeffer, Dietrich. Letters and papers from prison. Edited by Eberhard Bethge. Translated by Reginald H. Fuller. New York: Macmillan, 1953.

Cochran, Edwin A. 2012. The Cathedral of Commerce: The Highest Building in the World. Stockbridge: HardPress.

Darton, Eric. 1999. Divided We Stand: A Biography of the World Trade Center. New York: Basic Books.

Downton, Peter. 2003. Design Research. Melbourne: RMIT University Press.

Gonzaga, Vincent. 1998. Sacred Threshold. Virginia: Virginia Polytechnic.

Incorporated Church Building Society, London. 1957. Sixty Post-War Churches: Churches, Church Centres, Dual-purpose Churches. London: Incorporated Church Building Society.

Ito, Toyo. 1999. Blurring Architecture. Ludwig: suermondt ludwig museum.

Jetsonen, Sirkkaliisa. 2003. Sacral Space; Modern Finnish Churches. Tampere: TammerPaino Oy.

Kelly and Nelson, eds., (1995) Dietrich Bonhoeffer: A Testament to Freedom. HarperOne

Kilde, Jeanne Halgren. 2008. Sacred Power, Sacred Space : An Introduction to Christian Architecture and Worship. New York: Oxford University Press. 
- 2002. When the Church Bacame Theatre. New York: Oxford Press.

Leatherbarrow, David, and Mohsen Mostafavi. 2002. Surface Architecture. London: Mit Press.

Lentz, Carl. interview by Ahmed Shihab-Eldin. (December 2012). Hillsong Pastor Carl Lentz LIVE [Video file]. Retrieved from: http://live.huffingtonpost.com/r/segment/ hillsong-carl-lentz-pentecostal/52619bf6fe344453f70004da

Lentz, Carl. interview by Katie Couric. 2013. Who Is Carl Lentz? (December 19). [Video file]. Retrieved from: http://katiecouric.com/videos/who-is-carl-lentz/

Loveland, Anne C, and Otis B Wheeler. 2003. From Meetinghouse to Megachurch: A Material and Cultural History. Missouri : University of Missouri Press.

NBRS+PARTNERS. 2013. Hillsong Doody Street City Campus. March. Accessed August 25, 2013. http://www.nbrsap.com.au/project/hillsong-doodystreet-city-campus/.

Robertson, Kent A. 1995. "Downtown Redevelopment Strategies in the United States: An End of the Century Assesment." (Routleg).

Robinson, John. 1963. Honest to God. Great Britain: SCM Press.

Sovik, Edward. 1973. Architecture for worship. Michigan: Augsburg Pub. House.

Torgerson, Mark A. 2007. An Architecture of Immanence. Grand Rapids Michigan: WM B Eerdmans Publishing $\mathrm{Co}$

Tschumi, Bernard, and Irene Cheng. 2003. The State of Architecture at the Beginning of the 21st Century. New York: Monacelli Press.
Walden, Russel. 1998. Finnish Harvest. Keuruu: Otava Printing Works.

Baird, Julia. (2006, February 23). The good and bad of religion-lite. The Sydney Morning Herald. Retrieved from http: www.smh.com. au

Prince-Ramus, Joshua. (Oct 2009). Building a theater that remakes itself [Video file]. . theater_that_remakes_itself

Nishizawa, Taira. (2012 May 22). Wooden Works [Video file]. Retrieved from: http:// 
BIBLIOGRA$\mathrm{PHY}$

Adler, David. n.d. Metric Hand Book Planning and Design Data.

Bonhoeffer, Dietrich. Life together. Translated by John W.Doberstein. New York: Harper\&Row, 1954.

Bork, Robert Odell. 2003. Great spires: skyscrapers of the New Jerusalem. Cologne: University of Cologne.

Comper, J N. 1947. Of the Atmosphere of a Church. London: Sheldon Press.

Dahinden, Justus. 1968. New Trends in Church Architecture. New York: Universe Books.

Eugene and barbara sternberg.community centers and student unions.van nostrand reinhold company. new york. 1971

Comper, J N. 1947. Of the atmosphere of a church. Iondon sheldon press

Millward, Sally. 1998. Places of Worship. Wellington: Victoria University.

Mugerauer, Robert. 1995. Interpreting Environments. Austin: University of Texus Press.

Peter, Hammond. 1962. Towards a Church Architecture. London: The Architectural Press.

Incorporated church building society london. Sixty post-war churches churches church centres dual-purpose churches. 7 queen anne's gate, london.

Smith, G E Kidder. 1963. The new Churches of Europe. New York: Holt, Rinehart and Winston. 

Colossians 3:17 (NIV)

And whatever you do, whether in

word or deed, do it all in the name

of the Lord Jesus, giving thanks

to God the Father through him. 